This report was prepared as an account of work sponsored by an agency of the United States Government. Neither the United States Government nor any agency thereof, nor any of their employees, makes any warranty, express or implied, or assumes any legal liability or responsibility for the accuracy, completeness, or usefulness of any information, apparatus, product, or process disclosed, or represents that its use would not infringe privately owned rights. Reference herein to any specific commercial product, process, or service by trade name, trademark, manufacturer, or otherwise does not necessarily constitute or imply its endorsement, recommendation, or favoring by the United States Government or any agency thereof. The views and opinions of authors expressed herein do not necessarily state or reflect those of the United States Government or any agency thereof.

\title{
Methods for Verifying Compliance With Low-Level Radioactive Waste Acceptance Criteria
}

Published September 1993

\author{
Dames \& Moore \\ DOE Programs Group \\ 1125 Seventeenth Street, Suite 1200 \\ Denver, Colorado 80202-2027
}

Prepared for EG\&G Idaho, Inc.

Under Subcontract No. C90-132741-032

and for the

U.S. Department of Energy

National Low-Level Waste Management Program

Under DOE Idaho Operations Office

Contract DE-AC07-76ID01570 


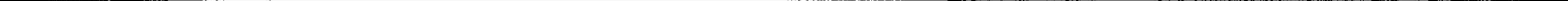




\section{DISCLAIMER}

Portions of this document may be illegible in electronic image products. Images are produced from the best available original document. 


\section{ABSTRACT}

This report summarizes the methods that are currently employed and those that can be used to verify compliance with low-level radioactive waste (LLW) disposal facility waste acceptance criteria (WAC). This report presents the applicable regulations representing the Federal, State, and site-specific criteria for accepting $L L W$. Typical LLW generators are summarized, along with descriptions of their waste streams and final waste forms. General procedures and methods used by the LLW generators to verify compliance with the disposal facility WAC are presented. The report was written to provide an understanding of how a regulator could verify compliance with a LLW disposal facility's WAC.

A comprehensive study of the methodology used to verify waste generator compliance with the disposal facility WAC is presented in this report. The study involved compiling the relevant regulations to define the WAC, reviewing regulatory agency inspection programs, and summarizing waste verification technology and equipment. The results of the study indicate that waste generators conduct verification programs that include packaging, classification, characterization, and stabilization elements. The current LLW disposal facilities perform waste verification steps on incoming shipments. A model inspection and verification program, which includes an emphasis on the generator's waste application documentation of their waste verification program, is recommended. The disposal facility verification procedures primarily involve the use of portable radiological survey instrumentation. The actual verification of generator compliance to the LLW disposal facility WAC is performed through a combination of incoming shipment checks and generator site audits. 



\section{EXECUTIVE SUMMARY}

This report summarizes the methods for verifying LLW generator compliance to LLW disposal facility WAC, applicable regulatory requirements, and available instrumentation. This report reviews and provides recommendations on the:

- Procedures used at the existing LLW facilities for compliance verification

- LLW generator compliance programs

- Instruments and technologies used or available for verification.

The purpose of this report is to create a reference to enable a regulator or disposal site operator to develop a strategy to verify generator compliance with disposal facility WAC. This report provides a summary of verification methods used by existing LLW disposal facilities. The report also presents recommendations for verifying LLW generator compliance with $L L W$ disposal facility WAC.

Regulatory requirements for LLW disposal involve four main areas of compliance; they are:

- Waste classification

- Waste characterization

- Waste form requirements

- Packaging and shipping requirements.

Each existing LLW disposal facility has specific radioactive material license conditions that incorporate any additional State regulatory requirements. Many of the requirements are primarily based upon U.S. Nuclear Regulatory Commission and U.S. Environmental Protection Agency standards. For example, the South Carolina Department of Health and Environmental Control has imposed certain site-specific requirements at the Barnwell facility that are waste form specific. The Washington Department of Health and the Nevada State Health Division have also identified specific waste form requirements within the U.S. Ecology, Inc. radioactive materials licenses.

Based on our findings, we understand that LLW generators have established WAC compliance programs that incorporate auditable checkpoints. The nuclear power industry has the most complex and largest WAC compliance program. Consolidated Edison Power Company provided some specific examples of a WAC compliance program. The commercial industry, consisting of universities, hospitals, and research facilities, have similar compliance programs but on a smaller scale because of their lower waste volumes. The NRC Branch Technical Position on Waste Forms, revised in January 1991, is one of the primary technical guidance documents to develop waste management programs for most generators. Each program provides auditable checkpoints through which generator audits can be conducted. 
The LLW disposal site operators have specific programs for verifying compliance with their WAC. Each program includes spot inspections at the disposal facility to encompass all of the compliance requirements in their license conditions. In addition, the disposal facility operator and regulators are conducting inspections at generator facilities to confirm the presence and proper execution of the generator compliance program requirements. The LLW disposal facility operators consider the frequency of inspection a proprietary matter, so frequency data could not be included in this report.

Based on the results of the research associated with developing this report, a model program was established. The model program could enable a regulator or disposal site operator to develop an auditable program for verifying WAC at LLW disposal facilities. This report presents a collection of the most current programs that are being implemented at the existing facilities. New facility operators and Host State regulators could use this report to better understand the reality of the WAC demonstration of compliance versus the state-of-the-art instrumentation claims. The methods currently used consist of technically simplistic instrumentation needs, containing a statistically justified sample and analysis program, and a generator audit program conducted by the disposal facility operators or host State regulator.

The data are developed from the instruments available for LLW activity contents analysis, which range from the most commonly used hand-held detectors to computerized controllers and data acquisition systems. The general categories of radiation detection and waste form instruments summarized include:

- Barrel monitors

- Hand held/portable radiation monitors

- Small containers/bag monitors

- Radioscopic/tomographic waste inspection equipment.

Within the commercial industry, the most commonly used instruments consist of hand-held equipment having limited sensitivity and application. More complex systems, such as real-time radiography applications, are found within U.S. Department of Energy facilities.

Methods for verifying generator compliance with disposal facility WAC include a combination of programs. Generators are incurring tremendous cost for LLW disposal; the motivation for developing extensive compliance programs is driven by the rising costs of disposal. The LLW disposal operators are conducting more inspections and generator site audits as regulators are developing tighter standards, while instrumentation manufacturers are developing more sensitive and reliable equipment recognizing the importance of compliance demonstration. 


\section{CONTENTS}

ABSTRACT $\ldots \ldots \ldots \ldots \ldots \ldots \ldots \ldots \ldots \ldots \ldots \ldots \ldots \ldots \ldots \ldots \ldots \ldots \ldots$

EXECUTTVE SUMMARY $\ldots \ldots \ldots \ldots \ldots \ldots \ldots \ldots \ldots \ldots \ldots \ldots \ldots \ldots \ldots \ldots$

ACRONYMS $\ldots \ldots \ldots \ldots \ldots \ldots \ldots \ldots \ldots \ldots \ldots \ldots \ldots \ldots \ldots \ldots \ldots \ldots \ldots \ldots$

1. INTRODUCTION $\ldots \ldots \ldots \ldots \ldots \ldots \ldots \ldots \ldots \ldots \ldots \ldots \ldots \ldots \ldots \ldots \ldots \ldots \ldots$

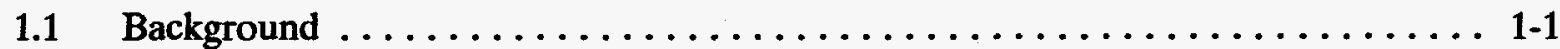

$1.2 \quad$ Purpose $\ldots \ldots \ldots \ldots \ldots \ldots \ldots \ldots \ldots \ldots \ldots \ldots \ldots \ldots \ldots \ldots \ldots \ldots \ldots$

1.3 Report Organization $\ldots \ldots \ldots \ldots \ldots \ldots \ldots \ldots \ldots \ldots \ldots \ldots \ldots \ldots \ldots \ldots$

2. REGULATIONS RELEVANT TO LOW-LEVEL RADIOACTIVE

WASTE ACCEPTANCE CRITERIA $\ldots \ldots \ldots \ldots \ldots \ldots \ldots \ldots \ldots \ldots \ldots \ldots \ldots \ldots$

2.1 Establishing a Regulatory Framework $\ldots \ldots \ldots \ldots \ldots \ldots \ldots \ldots \ldots \ldots$

2.1.1 Requirements of Nuclear Regulatory Commission Regulations and Guidance ............................. 2-1

2.1.2 Requirements of Department of Transportation Regulations . . . . . 2 2-14

2.1.3 State Regulations for Existing Low-Level Radioactive Waste Disposal Facilities . . . . . . . . . . . . . . . . 2-15

2.2 Disposal Site Waste Acceptance Criteria $\ldots \ldots \ldots \ldots \ldots \ldots \ldots \ldots \ldots$

2.3 Future Regulation of Low-Level Radioactive Waste Disposal . . . . . . . . 2-16

3. WASTE GENERATORS' CERTIFICATION PROGRAMS $\ldots \ldots \ldots \ldots \ldots \ldots \ldots$ 3-1

3.1 Types of Low-Level Radioactive Waste Generators $\ldots \ldots \ldots \ldots \ldots \ldots \ldots \ldots$ 3-1

3.1.1 Low-Level Radioactive Waste Characteristics . . . . . . . . . . . . 3-1

3.1.2 Summary of Low-Level Radioactive Waste Forms ............ 3-1

3.2 Generator Compliance with Waste Acceptance Criteria ............. 3-3

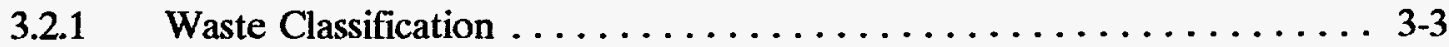

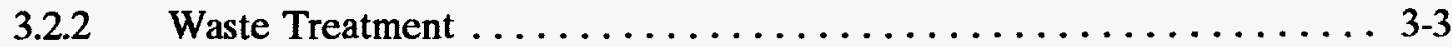

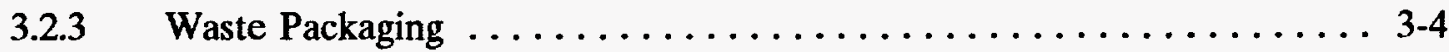

3.2.4 Summary of Generator Waste Forms $\ldots \ldots \ldots \ldots \ldots \ldots \ldots \ldots .6$ 
3.3 Programs for Verifying Generator Compliance With

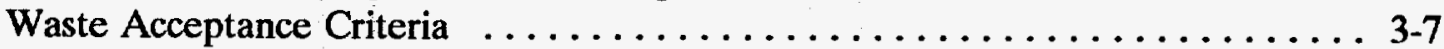

3.3.1 Nuclear Utility Low-Level Radioactive Waste Verification Programs ......................... 3-7

3.3.2 Institutional Low-Level Radioactive Waste Verification Programs ......................... 3-16

4. A SUMMARY OF DISPOSAL FACILITIES' PROGRAMS TO VERIFY COMPLIANCE WITH WASTE ACCEPTANCE CRITERIA

5. INSTRUMENTS AND TECHNOLOGIES TO VERIFY COMPLIANCE WITH WASTE

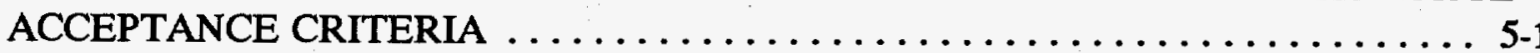

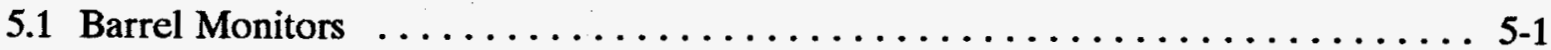

5.1.1 MBS-550 Waste Barrel Assay System ................ 5-2

5.1.2 $\mathrm{Q}^{2}$ Low Level Radioactive Waste Assay System - Canberra Nuclear . . 5-3

5.1.3 Model 2440 Waste Assay System - Canberra Nuclear .......... 5-4

5.1.4 Segmented Gamma Scanner-Harwell Instruments/EG\&G ORTEC $\ldots .5-5$

5.1.5 Model JCC-92 Passive/Active Neutron Shuffler System Canberra Nuclear ............................ 5-7

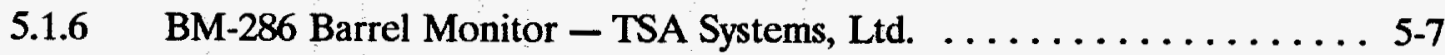

5.1.7 Segmented Gamma-Ray Scanner - Atlan-Tech, Inc. . . . . . . . . 5-8

5.2 Handheld/Portable Radiation Monitors $\ldots \ldots \ldots \ldots \ldots \ldots \ldots \ldots \ldots \ldots .6 .10 \ldots \ldots$

5.2.1 PRM-470A Portable Radiation Monitor - TSA Systems, Ltd. . . . . . 5-10

$5.2 .2 \quad$ NNV-470 - TSA Systems, Ltd. . ................ 5-11

5.2.3 Portable Hand-Held Multichannel Analyzer MCA-465 TSA Systems, Ltd. . . . . . . . . . . . . . . . . . $5-11$

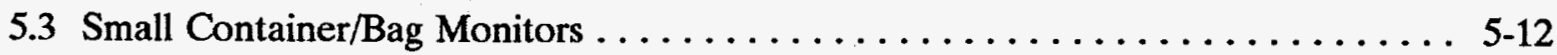

5.3.1 Small Articles Monitor SAM-1 - TSA Systems, Ltd. . . . . . . . 5-12

5.3.2 BM-285 Bag Monitor — TSA Systems, Ltd. . . . . . . . . . . 5-13

5.4 Radioscopic/Tomographic Waste Inspection Equipment $\ldots \ldots \ldots \ldots \ldots \ldots .6 .13$

5.4.1 ISOCON Camera-Based Imaging System - LumenX Company ...... 5-13

5.4.2 Waste Inspection Tomography System - Bio-Imaging Research, Inc. .. 5-14

6. MODEL INSPECTION AND VERIFICATION PROGRAM $\ldots \ldots \ldots \ldots \ldots \ldots 6-1$

6.1 Model Inspection and Verification Program Development ............. 6-2 
6.2 Structure of the Model Inspection and Verification Program $\ldots \ldots \ldots \ldots \ldots .2$

6.2.1 Generator Information . . . . . . . . . . . . . . .

6.2.2 Waste Certification Program $\ldots \ldots \ldots \ldots \ldots \ldots \ldots \ldots \ldots \ldots$ 6.4

6.2.3 Waste Stream Characterization Plan $\ldots \ldots \ldots \ldots \ldots \ldots \ldots \ldots . \ldots \ldots$

6.2.4 Procedures and Documentation .................. 6-5

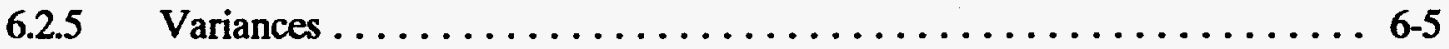

6.2.6 Generator Inspection Program ................... 6-5

6.2.7 Disposal Facility Inspection Program $\ldots \ldots \ldots \ldots \ldots \ldots \ldots \ldots$

6.3 Revisions to the Model Inspection and Verification Program . . . . . . . . . 6-7

7. CONCLUSION $\ldots \ldots \ldots \ldots \ldots \ldots \ldots \ldots \ldots \ldots \ldots \ldots \ldots \ldots \ldots \ldots \ldots \ldots$

8. $\quad$ REFERENCES $\ldots \ldots \ldots \ldots \ldots \ldots \ldots \ldots \ldots \ldots \ldots \ldots \ldots \ldots \ldots \ldots \ldots \ldots \ldots \ldots \ldots$

Appendix A-Samples of ConEd's Classification and Characterization Procedures $\ldots . .$. A-1

Appendix B-Radioactive Material Licenses for Low-Level Radioactive

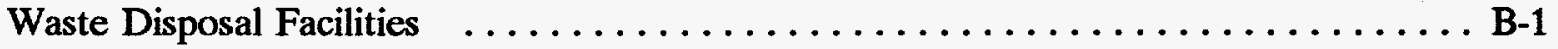

Appendix C-Point of Origin Inspection Report $\ldots \ldots \ldots \ldots \ldots \ldots \ldots \ldots \ldots \ldots \ldots$

\section{FIGURES}

4-1. Sample radioactive shipment manifest form $\ldots \ldots \ldots \ldots \ldots \ldots \ldots \ldots \ldots \ldots$

4-2. Manifest correction form $\ldots \ldots \ldots \ldots \ldots \ldots \ldots \ldots \ldots \ldots \ldots \ldots \ldots \ldots \ldots \ldots$

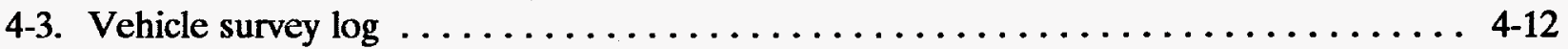

4-4. Incoming shipment acceptance procedure and checklist $\ldots \ldots \ldots \ldots \ldots \ldots \ldots$

4-5. Cask inspections form $\ldots \ldots \ldots \ldots \ldots \ldots \ldots \ldots \ldots \ldots \ldots \ldots \ldots \ldots \ldots$

4-6. Poly HIC engineered barrier receipt checklist $\ldots \ldots \ldots \ldots \ldots \ldots \ldots \ldots \ldots \ldots$

4-7. Package liquid verification checklist $\ldots \ldots \ldots \ldots \ldots \ldots \ldots \ldots \ldots \ldots \ldots \ldots \ldots \ldots \ldots$

\section{TABLES}

2-1. Commercial LLW site WAC-general $\ldots \ldots \ldots \ldots \ldots \ldots \ldots \ldots \ldots \ldots \ldots \ldots \ldots$ 
2-2. Commercial LLW site WAC-waste package $2-3$

2-3. Commercial LLW site WAC-waste form . $2-6$

2-4. Existing low-level radioactive waste disposal facilities

2-16

3-1. ConEd Indian Point Station radioactive waste cement BTP comparison 3-11

4-1. Disposal facility waste acceptance practices 4-8 


\section{ACRONYMS}

ADC analog-to-digital conversion

ALARA as low as reasonably achievable

BIR Bio-Imaging Research, Inc.

BTP Branch Technical Position

CFR Code of Federal Regulations

CNSI Chem-Nuclear Systems, Inc.

ConEd Consolidated Edison Power Company

CT computed tomography

DAW dry active waste

DHEC Department of Health and Environmental Control (South Carolina)

DOE Department of Energy

DOT Department of Transportation

HIC high-integrity container

HPGe high purity germanium

IAEA International Atomic Energy Agency

LANL Los Alamos National Laboratory

LLW low-level radioactive waste

LSA low specific activity

MIVP Model Inspection and Verification Program

NIM nuclear instrumentation module

NRC Nuclear Regulatory Commission

NYCRR New York Code of Rules and Regulations

PC personal computer 
process control program

PLC programmable logic controller

QC quality control

RCRA Resource Conservation and Recovery Act

RCO Radiation Control Office

RCS reactor coolant system

ROI region of interest

SGS segmented gamma scanner

SNM special nuclear material

TRU transuranic

USE U.S. Ecology, Inc.

WAC waste acceptance criteria

WTT waste inspection tomography 


\section{Methods for Verifying Compliance with Low-Level Radioactive Waste Acceptance Criteria}

\section{INTRODUCTION}

This report describes and summarizes the methods that are currently employed and those that can be used to verify compliance with low-level radioactive waste (LLW) disposal facility waste acceptance criteria (WAC).

\subsection{Background}

The Low-Level Radioactive Waste Policy Amendments Act of 1985 requires the U.S. Department of Energy (DOE) to provide technical assistance to the compact regions, host States, and unaffiliated States. The National Low-Level Waste Management Program, under subcontract to DOE, provides technical support to host States on the development of new lowlevel radioactive waste (LLW) disposal facilities.

\subsection{Purpose}

The purpose of this report is to provide a summary of the current practice for LLW WAC at each existing facility and to recommend additional techniques or methods for future sites. The report is intended to be used by LLW facility operators and host State regulators. Each generator could also benefit from understanding how compliance with the LLW WAC is verified at the existing LLW facilities. One objective of this report is to discuss various techniques for inspecting LLW for conformance to applicable waste treatment and packaging criteria. Various types of inspection technologies are discussed, including both intrusive and non-intrusive techniques.

This report presents the regulations and specific WAC applicable to:

- The commercial disposal of LLW

- A survey of the methods and procedures used by waste generators to certify that outgoing LLW meets disposal site WAC

- Typical methods used by the disposal sites to verify the waste generator's compliance with the disposal facility's WAC

- Examples of how regulatory agencies have reviewed LLW disposal facility compliance

- Current and future state-of-the-art instruments and technologies for radionuclide assay and waste form verification

- Instrumentation methods and technologies available for verification. 


\subsection{Report Organization}

The report addresses commercial LLW disposal verification only, and does not include any information related to LLW verification at DOE disposal facilities.

The report is divided into eight sections:

\section{Introduction}

\section{Regulations Relevant to LLW WAC}

\section{Summary of Waste Generators' Certification Program}

4. Summary of Disposal Facilities' Programs to Verify Compliance with WAC

5. Instruments and Technologies to Verify Compliance with WAC

6. Model Inspection and Verification Program

\section{Conclusion}

\section{References.}

Section 2 introduces the basic regulatory criteria from which specific disposal facility WAC are derived. The key requirements of the Code of Federal Regulations (CFR) and State regulations are summarized. The disposal facility host State regulations are reflected in the sitespecific WAC as specified in the facility operator's radioactive material license conditions. An example of the most recent regulations developed to govern operations of future LLW disposal sites is also discussed in Section 2.

Section 3 summarizes LLW generator certification programs and includes a typical power plant's program and example procedures for certifying that outgoing LLW meets disposal facility WAC. Many of the waste generators contacted in preparing this report were reluctant to provide procedures and manuals because of proprietary concerns regarding the release of information. A procedure from the Con Edison Indian Point nuclear power plant is included to serve as an example of a typical WAC verification procedure. The nuclear power industry was selected for the example because it has the most complex waste certification program other than DOE facilities. The procedures for verifying proper classification and characterization of LLW have been included as an example in Appendix A. The remaining LLW generators, such as universities and hospitals, typically have less resources available for managing the disposal of their smaller LLW volumes and, therefore, have smaller programs.

Section 4 summarizes WAC verification programs of operating disposal facilities. Section 4 also discusses the practices for verifying the LLW generator's conformance to the WAC requirements. For example, the disposal facility operators or State regulators perform inspections at the generator facilities. The frequency of inspections within a particular generator category is dependent on the volume of material disposed and the number of violations identified. Each 
disposal facility has specific radioactive material license conditions that identify acceptable limits for each radionuclide and waste form. A table summarizes the existing facility procedure for verifying WAC in Section 4. The existing disposal facility operators, U.S. Ecology, Inc. (USE), Chem-Nuclear Systems, Inc. (CNSI), and Envirocare of Utah expressed the same proprietary concerns regarding the release of detailed information on their inspection procedures as the nuclear utilities.

The instruments and supporting technologies used by the generators and the disposal facility operators to verify the waste form, packaging, and transportation requirements are presented in Section 5. The instruments and technologies include the administrative compliance functions, such as procedural implementation of checklists, which are presented in the preceding sections. Section 5 focuses on the state-of-the-art instruments and technologies available to support the verification process. Details regarding the instruments' capability and application are presented.

Section 6 discusses a Model Inspection and Verification Program, which was developed based upon LLW disposal facility WAC requirements discussed in Table 2-1 and in Section 4. The model program details the elements of a LLW generator application program that establishes the formal documentation of the LLW generator waste characterization and certification procedures. The model program was developed to provide additional information for future regulatory consideration.

Section 7, the conclusions section, briefly highlights the results of the reviews conducted in the preceding sections. The major compliance regulations and primary methods of verification are stated. Future trends and instrumentation availability are also discussed.

References are provided for all documents used in preparing this report. 


\section{REGULATIONS RELEVANT TO LOW-LEVEL RADIOACTIVE WASTE ACCEPTANCE CRITERIA}

Federal and State regulations govern waste form and packaging acceptance criteria for disposal. This section outlines the regulatory criteria under which existing LLW disposal facilities must operate. Future LLW disposal facilities will be required to meet these standards, which represent the basis for developing the site-specific WAC. The methods employed for inspecting and verifying compliance with commercial LLW disposal site WAC are driven by the technical performance specifications of the individual WAC. The following subsections discuss the regulatory framework from which the commercial LLW site WAC general criteria requirements are derived. A regulatory matrix of general, waste package, and waste form acceptance criteria are summarized in Tables 2-1, 2-2, and 2-3.

\subsection{Establishing a Regulatory Framework}

The Federal regulations that define the overall WAC for commercial LLW disposal with respect to shipment documentation and waste form are in the U.S. Nuclear Regulatory Commission's (NRC's) Title 10 "Energy," Part 20 "Standards for Protection Against Radiation," Part 61 "Licensing Requirements for Land Disposal of Radioactive Waste," and Part 71, "Packaging and Transportation of Radioactive Material." The U.S. Department of Transportation's Title 49, "Transportation," Part 173, defines the requirements for waste packaging during transport, which for most packages accepted for disposal also defines the waste package acceptance criteria. Specific sections of these regulations provide the overall requirements from which the disposal site WAC are derived.

The NRC has also published a "Branch Technical Position on Waste Form," which provides guidance on the acceptability of waste form and other characteristics of LLW for disposal. The guidance of the original Branch Technical Position (BTP), published in 1983, was adopted by the host States and implemented as conditions specific to the disposal facility operators' licenses by amendments. In January 1991, the NRC issued Revision 1 to the Waste Form BTP. It is expected that elements of this guidance, if not already implemented by the disposal facility operators, will be adopted and implemented through future license amendments.

\subsubsection{Requirements of Nuclear Regulatory Commission Regulations and Guidance}

10 CFR 61 is the principal NRC regulation that governs acceptable waste form and establishes the LLW classification system. 10 CFR 20 addresses the requirements pertaining to radioactive waste shipment manifests. $10 \mathrm{CFR} 71$ includes requirements specific to the packaging of LLW for transport. All of these regulations are cited in this report as criteria that must be met by the generator and the broker/processor to meet commercial disposal facility WAC and to gain access to the facility. At each disposal facility, the facility operator can refuse to receive waste that does not comply with the requirements of these regulations as directed by the operator's license conditions. The applicable requirements of these regulations and their identification as disposal facility WAC are discussed in the following subsections. 
Table 2-1. Commercial LLW site WAC - general.

\begin{tabular}{|c|c|c|}
\hline Criteria & Criteria designation & Criteria description \\
\hline $\begin{array}{l}\text { Shipment manifests and other } \\
\text { required documentation }\end{array}$ & $\begin{array}{l}\text { NRC } 20.311(b) \text { SCDHEC22 } \\
\text { CNSIDC 3.6.1 and } 6.0 \\
\text { WDH44.A NSHD37 }\end{array}$ & $\begin{array}{l}\text { Each shipment of LLW must be accompanied by a manifest meeting the equivalent } \\
\text { requirements of } 10 \text { CFR } 20.311 \text {. Some States have specified State manifest forms, } \\
\text { such as the Barnwell Radioactive Shipment Manifest (RSM) form. The manifest } \\
\text { must document the waste generator(s), the waste transporter, a physical description } \\
\text { of the waste, the volume, radionuclides, radioactivity quantities, principal chemical } \\
\text { form, solidification agent(s), weight percent of each chelating agent if }>1.0 \% \text { by } \\
\text { weight, waste class(es), and the total activity quantities of } H-3, \text { C-14, Tc- } 99 \text {, and } \\
\text { I-129 present in the waste. Broker/processor forms may also be required if the } \\
\text { shipment contains more than one generator's waste. Prior notification for special } \\
\text { hazards and Class C shipment forms may also be required. }\end{array}$ \\
\hline
\end{tabular}

NRC 20.311(C)

DOT 49 CFR SCDHEC 24

CNSIDC 3.6.4

WDH 16 NSHD 14
Each shipment must be certified on the accompanying manifest that the waste is properly classified, described, packaged, marked, labeled, and transported in accordance with applicable regulations of the U.S. Department of Transportation (DOT) and the NRC and, as applicable, the receiving State.

NRC20.311(Y) - - NRC 10 CFR Part 20, Section 20.311 (subsection "Y") "Transfer for Disposal and Manifests"

DOT 49CFR - DOT 49 CFR, "Transportation"

SCDHECXX(.Y) - South Carolina Department of Health and Environmental Control, Radioactive Material License Number 097, Amendment No. 45, CNSI, Inc., Barnwell Waste Management Facility License Condition No. "XX" (letter (".Y").

CNSIDCXX.X.X - CNSI Disposal Criteria, document no. S20-AD-010, criteria No. "XX.X(.X)"

WDHXX(.Y) - Washington Department of Health Radioactive Materials License Number WN-1019-2, Amendment No. 18, issued to USE, Richland Facility, License Condition number "XX" (letter ".Y").

NSHDXX(.Y) - Nevada State Health Division Radioactive Material License Number 13-11-0043, Amendment No. 13, issued to USE, Beatty Site, license condition number "XX (Letter ".Y"). 
Table 2-2. Commercial LLW site WAC - waste package.

\begin{tabular}{|c|c|c|}
\hline Criteria & Criteria designation & Criteria description \\
\hline Waste classification & $\begin{array}{l}\text { NRC } 20.311(\mathrm{~d}) \\
\text { NRC } 61.55 \\
\text { NRC } 61.57 \\
\text { SCDHEC } 31 \\
\text { CNSIDC } 8.1 \text { and } 8.4 \\
\text { WDH } 26 \\
\text { NSHD } 22\end{array}$ & $\begin{array}{l}\text { All waste packages must be prepared to be classified as Class } A \text { stable or unstable, } \\
\text { Class B, or Class C waste in accordance with the required classification scheme (i.e., } \\
10 \text { CFR } 61.55 \text { ), and labeled. Waste that contains concentrations of radionuclides } \\
\text { that exceed those allowable for Class C is generally unacceptable for near-surface } \\
\text { disposal. }\end{array}$ \\
\hline $\begin{array}{l}\text { External radiation and } \\
\text { contamination levels }\end{array}$ & $\begin{array}{l}\text { DOT } 173.441 \text { and } 173.443 \\
\text { SCDHEC } 59 \text { and } 60 \\
\text { CNSIDC } 8.0 \\
\text { WDH } 16 \text { and } 27 \\
\text { NSHD14 and } 23\end{array}$ & $\begin{array}{l}\text { Each waste package received must meet the requirements of DOT regulations } \\
\text { governing the radiation and contamination levels of the package and vehicle } \\
\text { exterior. }\end{array}$ \\
\hline Containerization & $\begin{array}{l}\text { DOT } 49 \text { CFR } \\
\text { SCDHEC } 54 \text { and } 59 \\
\text { CNSIDC } 12.0 \\
\text { WDH } 18 \\
\text { NSHD } 15\end{array}$ & $\begin{array}{l}\text { Waste must be transported and received in closed containers. For transport, waste } \\
\text { must be contained in either strong, tight packaging or Type A or Type B packaging } \\
\text { as required by DOT regulations. For disposal, the waste must be in closed } \\
\text { containers, usually in metal containers, unless otherwise authorized. }\end{array}$ \\
\hline Acceptable containers & $\begin{array}{l}\text { NRC } 61.56(a)(1) \\
\text { NRC } 71 \\
\text { DOT } 49 \text { CFR } \\
\text { SCDHEC } 59 \\
\text { CNSIDC } 8.7,8.9 \text { and } 13.12 \\
\text { WDH } 19 \\
\text { NSHD } 16\end{array}$ & $\begin{array}{l}\text { Waste containers must meet disposal site specific container requirements. At some } \\
\text { sites, the containers must meet DOT Specification } 7 \mathrm{~A} \text { criteria (Type A package). } \\
\text { However, cardboard and fiberboard boxes are not acceptable at any site, and } \\
\text { wooden boxes are not acceptable at certain sites. }\end{array}$ \\
\hline Container integrity & DOT 49CFR & $\begin{array}{l}\text { Waste package must be capable of withstanding the rigors of transport and handling } \\
\text { based on total activity and radionuclide concentration. In addition, container } \\
\text { closure devices must be securely fastened, containers must not be significantly } \\
\text { deformed, must not exhibit loss or dispersal of contents or increased external } \\
\text { radiation levels above those recorded on the manifest, and must not exhibit } \\
\text { degradation due to rust or other chemical action resulting in loss of container } \\
\text { integrity. }\end{array}$ \\
\hline
\end{tabular}


Table 2-2. (continued).

\begin{tabular}{|c|c|c|c|}
\hline \multicolumn{2}{|c|}{ Criteria } & Criteria designation & Criteria description \\
\hline \multicolumn{2}{|l|}{$\begin{array}{l}\text { Container integrity } \\
\text { (continued) }\end{array}$} & $\begin{array}{l}\text { SCDHEC } 60 \text { and } 61 \\
\text { CNSIDC } 8.8 \text { and } 9.1 .5 \\
\text { WDH } 19 \text { and } 20 \\
\text { NSHD } 16 \text { and } 17\end{array}$ & $\begin{array}{l}\text { Waste containers may be subject to design requirements to enhance structural } \\
\text { stability during handling, such as the metal banding of wooden boxes or the } \\
\text { attachment of lifting devices. In addition, special shielding added to the container } \\
\text { may require prior approval of the regulatory agency. }\end{array}$ \\
\hline \multicolumn{2}{|c|}{ Container configuration } & $\begin{array}{l}\text { SCDHEC } 64 \\
\text { CNSIDC 8.9, 8.12, 9.1.3, } \\
\text { 9.3.1, 9.3.2 }\end{array}$ & $\begin{array}{l}\text { All wooden boxes shall be banded with metal bands. Supplemental shielding may } \\
\text { require approval from the facility operator. Drum rings and bolts shall be secured } \\
\text { and structurally strong enough to support the weight of the drum while offloading. } \\
\text { Packages }>8,000 \text { pounds shall be provided with properly attached lifting devices. }\end{array}$ \\
\hline \multirow{2}{*}{\multicolumn{2}{|c|}{ Void spaces }} & $\begin{array}{l}\text { NRC 61.56(b)(3) } \\
\text { SCDHEC 39.C } \\
\text { WDH21 }\end{array}$ & $\begin{array}{l}\text { Void spaces within the waste and between the waste and its package must be } \\
\text { reduced to the extent practicable. }\end{array}$ \\
\hline & & $\begin{array}{l}\text { NSHD } 18 \\
\text { SCDHEC } 39 . \mathrm{C} \\
\text { WDH } 21 \\
\text { NSHD } 18\end{array}$ & $\begin{array}{l}\text { Class A stable, Class B and C waste packages must not contain void spaces greater } \\
\text { than } 15 \% \text { of the total package volume, provided the package is not a high integrity } \\
\text { container (HIC), nor a concrete overpack, nor contains activated metals too large to } \\
\text { be placed in HICs. }\end{array}$ \\
\hline \multicolumn{2}{|c|}{ Special container requirements } & $\begin{array}{l}\text { SCDHEC 32.C, 39.B, } 45,47 \\
\text { and } 53 \\
\text { CNSIDC } 13.1,13.3,13.7 \\
\text { and } 13.12 \\
\text { WDH } 32,33,34,35 \text { and } 38 \\
\text { NSDH } 27,28,29,30,31 \\
\text { and } 32\end{array}$ & $\begin{array}{l}\text { Use of special packaging, such as HICs, concrete overpacks, and polyethylene liners, } \\
\text { is acceptable in lieu of meeting structural stability waste form requirements for } \\
\text { certain wastes such as sealed sources, special form materials, irradiated metal } \\
\text { components, biological wastes, special nuclear material, and incinerator ash. }\end{array}$ \\
\hline NRC20.311(Y) & \multicolumn{3}{|c|}{ NRC 10 CFR 20, Section 20.311 (subsection "Y") "Transfer for Disposal and Manifests" } \\
\hline DOT 49CFR & \multicolumn{3}{|c|}{ DOT 49 CFR "Transportation" } \\
\hline NRC61.55 & \multicolumn{3}{|c|}{ NRC 10 CFR 61, Section 61.55 "Waste Classification" } \\
\hline NRC61.56(Y)(X) & \multicolumn{3}{|c|}{ NRC 10 CFR 61, Section 61.56 (subsection "Y") (paragraph "X") "Waste Characteristics" } \\
\hline NRC 61.57 & \multicolumn{3}{|c|}{ NRC 10 CFR 61, Section 61.57 "Labeling" } \\
\hline NRC 71 & \multicolumn{3}{|c|}{ NRC 10 CFR 71 "Packaging and Transportation of Radioactive Material" } \\
\hline DOT 173.441 & \multicolumn{3}{|c|}{ DOT 49 CFR 173, Section 173.441 "Radiation level limitations" } \\
\hline
\end{tabular}


Table 2-2. (continued).

DOT 173.443 - DOT 49CFR 173, Section 173.443 "Contamination Control"

SCDHECXX(.Y) - South Carolina Department of Health and Environmental Control, Radioactive Material License Number 097, Amendment No. 45, issued to CNSI, Barnwell Waste Management Facility License Condition No. "XX" (letter (".Y").

CNSIDCXX.X.X - $\quad$ CNSI Disposal Criteria, document No. S20-AD-010, criteria No. "XX.X(.X)"

WDHXX(.Y) - Washington Department of Health Radioactive Materials License Number WN-I019-2, Amendment No. 18, issued to USE, Richland Facility, License Condition number "XX" (letter ".Y").

NSHDXX(.Y) - Nevada State Health Division Radioactive Material License Number 13-11-0043, Amendment No. 13, issued to USE, Beatty Site, license condition number "XX (Letter ".Y"). 
Table 2-3. Commercial LLW site WAC - waste form.

\begin{tabular}{lll}
\hline Criteria & Criteria designation & Criteria description \\
\hline Stability & &
\end{tabular}

Stability

NRC 61.56(b) - General

Structural stability

NRC 61.56(b)(1)

NRC 61.7(b)(2)

SCDHEC 39.A and 39.B

Solidification media and processes

SCDHEC 33.B-D

WDH 26 and 36

NSHD 22.C
The following criteria are intended to provide stability of disposed waste. Stability is intended to ensure that the waste does not structurally degrade and thus affect the structural integrity of the disposal site through subsidence, collapse, or other failure leading to water infiltration. Stability also increases the likelihood of limiting exposure to the inadvertent intruder by providing a more recognizable and nondispersable waste.

Solidified Class $\mathbf{A}$ waste containing radionuclides with greater than five-year halflives and a total specific activity $>1$ microcurie per cubic centimeter and Class B and $\mathrm{C}$ waste must be structurally stable and be capable of maintaining its general physical dimensions and its form under expected disposal conditions. Structural stability can be provided by the waste form itself (such as special form material), processing the waste to a stable form, or placing the waste in an approved, high integrity container.

A structurally stable waste form will generally maintain its physical dimensions and its form under the expected disposal conditions, such as weight of overburden and compaction equipment, the presence of moisture, and microbial activity, and internal factors such as radiation effects and chemical changes. Class B and C waste forms or containers should be designed to be stable, i.e., maintain gross physical properties and identity, over 300 years.

Solidified Class A waste containing radionuclides with greater than five-year halflives and a total specific activity $>1$ microcurie per cubic centimeter, and Class B and $\mathrm{C}$ waste are not acceptable unless they meet the requirements of NRC 61.56(b)(1). Structural stability can be provided by the waste form itself, processing the waste to a stable form, or placing the waste in an approved high integrity container.

Solidification media and processes used to stabilize Class A waste containing radionuclides with greater than five year half-lives and a total specific activity $>1$ microcurie per cubic centimeter, and all Class $B$ and $C$ waste, must be evaluated and meet stability guidance requirements of the NRC's "BTP on Waste Form"n (Revision 1, January 1991), or other specifically approved criteria.

Solidified Class A aqueous liquids and other applicable waste forms with a specific activity of less than 1 microcurie per cubic centimeter must meet the requirements of the solidified Class A waste products of the "BTP on Waste Form." 
Table 2-3. (continued).

\begin{tabular}{|c|c|c|}
\hline Criteria & Criteria designation & Criteria description \\
\hline \multirow[t]{2}{*}{$\begin{array}{l}\text { Solidification media and processes } \\
\text { (continued) }\end{array}$} & SCDHEC 33.E & $\begin{array}{l}\text { Waste solidified in bitumen must be full-form, oxidized bitumen, certified by the } \\
\text { generator. It must be a free-standing monolith, and shall not be a free-flowing, } \\
\text { viscous fluid. }\end{array}$ \\
\hline & $\begin{array}{l}\text { WDH 26.D } \\
\text { NSHD 22.C }\end{array}$ & $\begin{array}{l}\text { Waste must be stabilized in accordance with criteria contained in the most recent } \\
\text { version (Revision 1, January 1991) of the BTP on waste form issued by the } \\
\text { USNRC, and procedures that are described in approved vendor typical reports. } \\
\text { Only approved stabilization media and high integrity containers may be accepted. }\end{array}$ \\
\hline \multirow[t]{2}{*}{$\begin{array}{l}\text { Evaporator bottoms, purification } \\
\text { media }\end{array}$} & SCDHEC 35 and 38 & $\begin{array}{l}\text { Evaporator bottoms, residues, sludges, ion exchange resin, and filter media must be } \\
\text { solidified in accordance with acceptable solidification media and processes as } \\
\text { required by SCDHEC } 33 \text {. }\end{array}$ \\
\hline & WDH 36.A and B & $\begin{array}{l}\text { Class A ion exchange and filter media containing radionuclides with half-lives } \\
\text { greater than five years, the total concentration of which is } 1 \text { microcurie per cubic } \\
\text { centimeter or greater, except Co-60 having a concentration of } 50 \text { microcuries per } \\
\text { cubic centimeter or greater, must meet the stability requirements of WDH } 26 \text { and } \\
\text { shall contain no detectable free-standing liquid, as little liquid as reasonable } \\
\text { achievable, but in no case exceeding } 1.0 \% \text { of the volume of the waste when the } \\
\text { waste is in a disposal container designed to ensure stability, or } 0.5 \% \text { of the volume } \\
\text { of waste processed to a stable form. Other Class A ion exchange and filter media } \\
\text { that are classified as unstable must contain no more liquid than } 0.5 \% \text { by volume of } \\
\text { waste. }\end{array}$ \\
\hline
\end{tabular}

The calculation of concentrations of radionuclide activity must adhere to the "sum of fractions being equal to or less than unity rule" for ion exchange resins and filter media containing radionuclides with half-lives greater than five years, with the exception of Co-60.

Incinerator ash or powder must be solidified in accordance with acceptable solidification media and processes as required by SCDHEC33. 
Table 2-3. (continued).

\begin{tabular}{|c|c|c|}
\hline Criteria & Criteria designation & Criteria description \\
\hline \multirow[t]{2}{*}{ Liquid content } & SCDHEC32.A and 34 & $\begin{array}{l}\text { Liquids must not be accepted for disposal, regardless of the chemical or physical } \\
\text { form. Absorbed liquids are not acceptable. Dewatered resins and fitter media, } \\
\text { other than those meeting the criteria of SCDHEC } 38 \text {, are acceptable. }\end{array}$ \\
\hline & $\begin{array}{l}\text { NRC61.56(a)(2) } \\
\text { WDH24 } \\
\text { NSHD21 }\end{array}$ & $\begin{array}{l}\text { Liquid wastes must be solidified, stabilized, or packaged in sufficient absorbent } \\
\text { material to absorb at least twice the volume of liquid. }\end{array}$ \\
\hline \multirow[t]{4}{*}{ Solidified liquids } & $\begin{array}{l}\text { NRC61.56(a)(3) and }(b)(2) \\
\text { SCDHEC32.B } \\
\text { WDH30 } \\
\text { NSHD26 }\end{array}$ & $\begin{array}{l}\text { Solidified radioactive waste must have no free-standing liquids in excess of } 0.5 \% \text { of } \\
\text { the waste package volume unless in a HIC, which has a } 1 \% \text { limit. }\end{array}$ \\
\hline & $\operatorname{NRC61.56(a)(2)~and~(a)(3)~}$ & $\begin{array}{l}\text { Liquid waste must be solidified or packaged in sufficient absorbent material to } \\
\text { absorb twice the volume of the liquid. Solid waste containing liquid shall contain as } \\
\text { little free-standing and noncorrosive liquid as is reasonably achievable, but in no } \\
\text { case shall the liquid exceed } 1 \% \text { of the volume. }\end{array}$ \\
\hline & $\begin{array}{l}\text { SCDHEC 32.B } \\
\text { WDH } 30 \\
\text { NSHD } 26\end{array}$ & $\begin{array}{l}\text { Solidified radioactive waste must have no free-standing liquids in excess of } 0.5 \% \text { of } \\
\text { the waste package volume unless in a HIC, which has a } 1 \% \text { limit. }\end{array}$ \\
\hline & $\begin{array}{l}\text { SCDHEC33.A } \\
\text { CNSIDC } 13.4 \\
\text { WDH30 } \\
\text { NSHD26 }\end{array}$ & Liquid waste must be solidified with an approved solidification medium. \\
\hline Stabilized liquids & $\begin{array}{l}\text { NRC61.56(b)(2) } \\
\text { WDH29 } \\
\text { NSHD25 }\end{array}$ & $\begin{array}{l}\text { Liquid waste or wastes containing liquid must be converted into a form that } \\
\text { contains as little free-standing and noncorrosive liquid as is reasonably achievable, } \\
\text { but in no case shall the liquid exceed } 1 \% \text { of the volume of the waste when the } \\
\text { waste is in a disposal container designed to ensure stability, or } 0.5 \% \text { of the volume } \\
\text { of the waste for waste processed to a stable form. }\end{array}$ \\
\hline Sorbed liquids & $\begin{array}{l}\text { NRC61.56(a)(2) } \\
\text { WDH3 }\end{array}$ & $\begin{array}{l}\text { Liquid waste must be absorbed in sufficient approved sorbent material to absorb at } \\
\text { least twice the volume of liquid, and must also be specially packaged. }\end{array}$ \\
\hline
\end{tabular}

NSHD27 
Table 2-3. (continued).

\begin{tabular}{|c|c|c|}
\hline Criteria & Criteria designation & Criteria description \\
\hline Health and safety protection & NRC61.56(a) - General & $\begin{array}{l}\text { The following criteria are intended to facilitate waste handling at the disposal site } \\
\text { and provide health and safety protection to disposal site personnel. }\end{array}$ \\
\hline Explosivity and reactivity & $\begin{array}{l}\text { NRC61.56(a)(4) } \\
\text { SCDHEC49 } \\
\text { CNSIDC13.6.3 } \\
\text { WDH23 } \\
\text { NSHD20 }\end{array}$ & $\begin{array}{l}\text { Waste must not be readily capable of denotation or of explosive decomposition or } \\
\text { reaction at normal pressures and temperatures, or of explosive reaction with water. }\end{array}$ \\
\hline Toxicity & $\begin{array}{l}\text { NRC61.56(a)(5) } \\
\text { SCDHEC50 } \\
\text { WDH22 } \\
\text { NSHD19 }\end{array}$ & $\begin{array}{l}\text { Waste must not contain or be capable of generating quantities of toxic gases, } \\
\text { vapors, or fumes harmful to persons transporting, handling, or disposing of the } \\
\text { waste. This does not apply to gaseous waste packaged in accordance with applicable } \\
\text { regulations. }\end{array}$ \\
\hline Pyrophoric & $\begin{array}{l}\text { NRC61.56(a)(6) } \\
\text { SCDHEC51 } \\
\text { CNSIDC13.6 } \\
\text { WDH23 } \\
\text { NSHD20 }\end{array}$ & $\begin{array}{l}\text { Waste must not be pyrophoric. Pyrophoric or flammable materials in the waste } \\
\text { must be treated, prepared, and packaged to be nonflammable. }\end{array}$ \\
\hline Gaseous & $\begin{array}{l}\text { NRC61.56(a)(7) } \\
\text { SCDHEC47.A-C } \\
\text { CNSIDC13.2 } \\
\text { WDH35 } \\
\text { NSHD30 }\end{array}$ & $\begin{array}{l}\text { Acceptable gaseous waste must be packaged in DOT specification cylinders or } \\
\text { approved sealed sources, at a pressure that does not exceed } 1.5 \text { atmospheres at } \\
20^{\circ} \mathrm{C} \text {. Total activity must not exceed } 100 \text { curies per container. }\end{array}$ \\
\hline $\begin{array}{l}\text { Biological, including animal } \\
\text { carcasses }\end{array}$ & $\begin{array}{l}\text { NRC } 61.56(a)(8) \\
\text { SCDHEC } 53 \\
\text { CNSIDC } \\
\text { WDH } 33 \text { and } 34 \\
\text { NSHD } 28 \text { and } 29\end{array}$ & $\begin{array}{l}\text { Waste containing biological, pathogenic, or infectious material must be treated to } \\
\text { reduce, to the maximum extent practicable, the potential hazard from the materials, } \\
\text { and must be specially packaged with double containers, lime slake, absorbent, and } \\
\text { plastic liners. }\end{array}$ \\
\hline
\end{tabular}


Table 2-3. (continued).

\begin{tabular}{|c|c|c|}
\hline Criteria & Criteria designation & Criteria description \\
\hline \multirow[t]{2}{*}{ Hazardous/mixed waste } & $\begin{array}{l}\text { NRC61.56(a)(8) } \\
\text { SCDHEC43, 48.B and } 53 \\
\text { CNSIDC13.8 and } 13.17\end{array}$ & $\begin{array}{l}\text { Waste containing hazardous material must be treated to reduce, to the maximum } \\
\text { extent practicable the potential hazard from the material, to render it not subject to } \\
\text { the Resource Conservation and Recovery Act (RCRA). Waste containing discrete } \\
\text { quantities of hazardous or toxic materials may be evaluated and submitted for } \\
\text { approved disposal. }\end{array}$ \\
\hline & $\begin{array}{l}\text { SCDHEC48.A } \\
\text { WDH17 and } 23 \\
\text { NSHD20 }\end{array}$ & $\begin{array}{l}\text { Hazardous or mixed wastes must not be accepted for disposal, unless otherwise } \\
\text { authorized. }\end{array}$ \\
\hline
\end{tabular}

Other criteria

Filter and ion exchange media activity content
Various State Regulations and License Conditions

\section{SCDHEC37}

\section{SCDHEC40 and 41} WDH38

WDH28

NSHD24

\section{SCDHEC44.A-C}

WDH37

SCDHEC46 CNSIDC13.15
The following criteria impose restrictions on received waste other than those specified for purposes of stability, or health and safety protection.

Filter and ion exchange media waste must be accompanied by records of complete radiological analysis (quantitative and qualitative).

Except as permitted by waste class, waste containing transuranic (TRU) nuclides must not be accepted. Acceptable TRU nuclides must be homogeneously distributed in the waste form. Am-241 smoke or gas detector foils are acceptable, provided the entire detector is received for disposal.

Except as otherwise authorized, untreated liquids and wet sludges must not be accepted. Liquids must be rendered noncorrosive $(4 \leq \mathrm{ph} \leq 11)$ prior to treatment. Wet sludges and slurries, such as evaporator bottoms, must be noncorrosive and treated by stabilization or solidification. Ion exchange media must not be treated by sorption.

Radium waste must not be accepted except for solid homogenous waste, consumer products provided the entire product is received for disposal, and biological research waste.

Waste containing chelating agents with concentrations greater than $8 \%$ by weight must not be accepted. Waste containing chelating agents in the range of 0.1 to $8 \%$ must be stabilized by solidification with an acceptable medium.

WDH41

NSHD40
Wastes containing chelating agents in concentrations greater than $1.0 \%$ by weight must be treated for stabilization prior to disposal. 
Table 2-3. (continued).

\begin{tabular}{|c|c|c|c|}
\hline \multicolumn{2}{|c|}{ Criteria } & Criteria designation & Criteria description \\
\hline \multirow{2}{*}{\multicolumn{2}{|c|}{ Oils }} & $\begin{array}{l}\text { SCDHEC52 } \\
\text { CNSIDC13.5 }\end{array}$ & $\begin{array}{l}\text { Wastes containing oil or petroleum-based materials must not be accepted in any } \\
\text { physical form, except for incidental or trace amounts that have been absorbed, } \\
\text { provided that the amount does not exceed } 1 \% \text { by waste volume in a container. }\end{array}$ \\
\hline & & $\begin{array}{l}\text { WDH40 } \\
\text { NSHD35 }\end{array}$ & $\begin{array}{l}\text { Pretreatment waste liquids containing oil greater than } 10 \% \text { by weight must be } \\
\text { stabilized prior to disposal. }\end{array}$ \\
\hline Neutron sources & & $\begin{array}{l}\text { WDH42 } \\
\text { NSHD34 }\end{array}$ & $\begin{array}{l}\text { Generators of neutron source waste (Am-241, Po-210, Ra-226 in combination with } \\
\text { beryllium or other target) must notify the disposal site by telephone and in writing } \\
\text { prior to shipment. All pertinent radiological and shipment data must be provided. }\end{array}$ \\
\hline $\mathrm{NRC} 61.56(\mathrm{Y})(\mathrm{X})$ & - & \multicolumn{2}{|c|}{ USNRC 10 CFR Part 61, Section 61.56 (subsection "Y") (paragraph "X") "Waste Characteristics" } \\
\hline SCDHECXX(.Y) & - & \multicolumn{2}{|c|}{$\begin{array}{l}\text { South Carolina Department of Health and Environmental Control, Radioactive Material License Number 097, Amendment No. } 45 \text {, } \\
\text { issued to Chem-Nuclear Systems, Inc., Barnwell Waste Management Facility License Condition No. "XX" (letter (".Y"). }\end{array}$} \\
\hline CNSIDCXX.X.X & - & \multicolumn{2}{|c|}{ Chem-Nuclear Systems, Inc. Disposal Criteria, document no. S20-AD-010, criteria No. "XX.X(.X)" } \\
\hline WDHXX(.Y) & - & \multicolumn{2}{|c|}{$\begin{array}{l}\text { Washington Department of Health Radioactive Materials License Number WN-I019-2, Amendment No. 18, issued to U.S. Ecology, } \\
\text { Inc., Richland Facility, License Condition number "XX" (letter ".Y"). }\end{array}$} \\
\hline NSHDXX(.Y) & - & \multicolumn{2}{|c|}{$\begin{array}{l}\text { Nevada State Health Division Radioactive Material License Number 13-11-0043, Amendment No. 13, issued to U.S. Ecology, Inc., } \\
\text { Beatty Site, license condition number "XX (Letter ".Y"). }\end{array}$} \\
\hline
\end{tabular}


2.1.1.1 10 CFR 20, Standards for Protection Against Radiation. 10 CFR 20, Section 20.311, "Transfer for Disposal and Manifests," requires that all shipments of LLW to a disposal facility be accompanied by a shipment manifest that identifies the transporter and information specific to the contents of the waste shipment. The manifest must also include a certification by the waste generator that the transported waste was prepared in accordance with the classification requirements of 10 CFR 20.311 and 10 CFR 61.55, and in accordance with applicable Department of Transportation (DOT) regulations. Section 20.311 also establishes the required exchange of manifest documentation between the generator, waste processor, transporter, and disposal facility operator. Receipt of a properly completed LLW shipment manifest is an acceptance requirement of all LLW disposal facilities.

In addition to a shipment manifest, the regulatory agencies and disposal facilities impose additional documentation requirements on waste transporters. For example, for the waste to be acceptable at the Barnwell facility, a transporter must have a valid Radioactive Waste Transport Permit from the South Carolina Department of Health and Environmental Control (DHEC), and must include a completed CNSI Broker/Processor Form with all shipments containing more than one generator's LLW.

However, these requirements generally originate locally and are not explicitly established by the NRC. Therefore, they have not been separately identified as specific WAC in Table 2-1.

\subsubsection{10 CFR 61, Licensing Requirements for Land Disposal of Radioactive Waste.} There are several requirements of 10 CFR 61 that are the basis for the majority of the LLW disposal facility WAC. The requirements of 10 CFR 61 that address disposal facility siting, waste classification, and waste characteristics are oriented to ensure that the long-term performance of the facility, results in full compliance with the $10 \mathrm{CFR} 61$ performance objectives. By requiring practices such as segregating the greater hazard LLW from the lower hazard LLW, designing engineering enhancements to provide and sustain a greater barrier to inadvertent human intrusion, and controlling subsurface release of radionuclides, the probability of achieving longterm positive performance is significantly increased. The stability of the waste package and waste form play a key role in achieving such performance.

10 CFR 61.55, "Waste Classification," provides a system to classify waste as Class A, Class B, and Class $\mathrm{C}$, based on radionuclide concentration and half-life. Section 61.56 contains waste characterization requirements based on classification. $10 \mathrm{CFR} 61$ details specific requirements that all waste classes must meet prior to disposal. Additionally, Class B and Class $C$ wastes are required to have "structural stability." Criteria defining this characteristic are delineated in the NRC's "BTP on Waste Form."

2.1.1.3 10 CFR 71, Packaging and Transportation of Radioactive Material. 10 CFR 71 pertains to packaging and transport of radioactive material exceeding Type A quantities, defines design criteria for Type B packages, and limits the type, amount, and form of radioactive material allowed in these packages. Packages containing greater than a Type A quantity of radioactive 
material (Type B packages) must be designed to retain containment integrity and shielding under normal and abnormal (accident) conditions of transport. DOT regulates the transport of Type A quantities of radioactive material. (Note: "Type A" quantities discussed in this paragraph are different than "Class A" wastes discussed above. "Type" is based on quantity while "Class" is based on concentration).

2.1.1.4 Nuclear Regulatory Commission Guidance. Since the promulgation of 10 CFR 61, the NRC has issued guidance on desired LLW waste form for disposal, storage of LLW at nuclear power plants, and storage by fuel cycle and other materials licensees. This guidance is in the form of BTPs, NRC letters, and information notices.

The "BTP on Waste Form" provides guidance on minimum waste form requirements for Class A, B, and C LLW. The primary waste form issue addressed by the BTP is that Class B and $\mathrm{C}$ waste, and any Class $\mathrm{A}$ waste disposed in the same disposal unit with Class $\mathrm{B}$ and $\mathrm{C}$ waste, should retain its structural integrity for at least 300 years. The BTP provides requirements and tests to provide reasonable assurance that this requirement is met.

The purpose of these requirements is to prevent slumping and collapse of the cap or cover over the disposal units, thus limiting the infiltration of water in contact with the waste. Assurance of structural stability can be provided by:

- The generated waste form itself

- Processing the waste to a stable form, such as solidification

- Placing the waste in unstable form in a container that provides stability, such as a highintegrity container (HIC).

The BTP specifies the following requirements if a $\mathrm{HIC}$ is used to maintain structural stability:

- The maximum allowable free liquid in a $\mathrm{HIC}$ is less than $1 \%$ of the waste volume

- The HIC's design life is 300 years

- HIC design considers corrosive and chemical effects of both the waste contents and the disposal trench environment, and the thermal loads from processing, storage, transportation, and burial, and considers the biodegradation properties of the container materials

- HICs withstand the routine loads and effects from the waste contents, waste preparations, transportation, and disposal site operations

- HIC design considers the radiation stability of the container materials and radiation degradation effects of the wastes; polymeric HIC designs also considers the effects of ultraviolet radiation 
- HICs meet the requirements for a Type A package as specified in 49 CFR 173.411 and 173.412, and the free drop test in 10 CFR 71.71

- HIC closures design provide a positive seal for the design lifetime of the container.

NRC Generic Letter 81-38: "Storage of Low-Level Radioactive Wastes at Power Reactor Sites" is specific to storage of waste prior to shipment for disposal. It was generated as a result of decreased waste disposal availability in the late 1970 s and provides radiological safety guidance for onsite storage of LLW.

NRC Information Notice No. 90-09: "Extended Storage of Low-Level Radioactive Waste by Fuel Cycle and Materials Licensees" provides instruction on the information needed in license amendment requests to authorize extended interim storage. Although this waste is targeted for extended storage, it will eventually be disposed and, thus, must satisfy established WAC for packaging, storage, and eventual disposal. Significant requirements of the information notice include the following:

- Process waste before storage and package in a form ready for transport and disposal at the end of the storage period

- Shield stored waste from the elements and from extremes of temperature and humidity

- Evaluate decomposition and chemical reaction of incompatible waste materials leading to gas generation or other reaction products.

\subsubsection{Requirements of Department of Transportation Regulations}

The 49 CFR, "Transportation," regulations contain the majority of the regulations applicable to radioactive material packaging, primarily 49 CFR 173, "General Requirements for Shipments and Packaging." Low specific activity (LSA) material, which comprises most LLW shipments, may be shipped in "strong, tight packages," which must meet only the design criteria given in Section 173.24, "Standard Requirements for All Packages." Complete transport requirements for LSA waste are described in Section 173.425. Sections 173.401 through 173.478 define design criteria for Type A and Type B packages. Typically, Type A packages are designed to the performance-based DOT Specification 7A criteria (178.350) and require certification as such. Type A packages do not require prior approval from DOT or the NRC for use. Type B packages require NRC approval before use and must meet very stringent design criteria based on hypothetical accident conditions (10 CFR 71.72). Because WAC inherently encompass acceptance of the container that holds the wastes, it is important to note that "strong, tight packages" and some kinds of Type A packages, such as fiberboard boxes, do not lend sufficient stability to the waste after emplacement in disposal units and are, therefore, not acceptable waste packages at some disposal facilities.

DOT has proposed a revision to its regulations related to transport of radioactive material to obtain compatibility with the regulations of the International Atomic Energy Agency (IAEA). These changes primarily affect the limits on package contents and the package design criteria. 
Since finalization of these revisions has been in progress for several years and is now temporarily suspended, the specific content and timing of DOT's promulgation of these regulations is not known.

\subsubsection{State Regulations for Existing Low-Level Radioactive Waste Disposal Facilities}

In addition to the Federal regulations and guidance, each host State has promulgated a set of State regulations that adopt and implement the Federal regulations. The regulatory agencies of each host State have entered into Agreement State programs with the NRC, which delegate the authority to implement and enforce NRC regulations to the host States, with the general requirement that the State regulatory program be compatible with the NRC's regulations. The NRC reserves licensing jurisdiction in Agreement States over special nuclear material (SNM) in quantities in excess of 350 grams U-235 and 200 grams U-233 and Pu, including SNM components in LLW, in every State.

Each host State's regulatory WAC are essentially equivalent to those of the NRC for 10 CFR 61 licensed disposal facilities. All of the host States also impose additional WAC on received waste, beyond those established in the NRC regulations. The host State directs the LLW disposal site operator to implement the WAC requirements by issuing a radioactive materials license that authorizes the operator to accept and dispose LLW. Each site license contains conditions that provide specific direction to the operator of the disposal site on the acceptability of incoming LLW with regard to documentation, waste form, waste packaging, and other operational requirements.

The relative geographic location of the disposal site drives the degree to which waste form restrictions are applied to incoming LLW. Specifically, the Barnwell facility, located in the southeast U.S., experiences greater annual precipitation and is characterized by a shorter depth to groundwater than the disposal sites in the arid, western U.S. It follows that additional, more rigorous waste form criteria related to ensuring the stability of disposed LLW are imposed on generators shipping waste to the Barnwell facility than to the western sites.

\subsection{Disposal Site Waste Acceptance Criteria}

The basis of the regulatory requirements of 10 CFR 20,61, and 71, 49 CFR, and the guidance of the "BTP on Waste Form" and their inclusion as disposal facility WAC are discussed in this section. Currently, there are three licensed commercial LLW disposal facilities in the United States; a fourth licensed facility located in Clive, Utah is only allowed to receive low concentrations of large volumes of LLW. These facilities are listed in Table 2-4 with their status, location, and operator. The specific LLW WAC are not published as stand-alone documents for any of these sites, except Barnwell. CNSI published the CNSI Disposal Criteria document, which provides detailed requirements that the waste generator must meet for waste to be received at Barnwell. At the other three facilities, the WAC are identified as specific disposal facility license conditions established by the licensing authorities in each host State.

With the exception of the Clive site, all of the currently licensed LLW disposal facilities were developed and began operations prior to 10 CFR 61 regulations. The WAC within the license condition for each facility may not include requirements that specify the necessary waste 
Table 2-4. Existing low-level radioactive waste disposal facilities.

\begin{tabular}{lcc}
\hline \multicolumn{1}{c}{ Location } & Operator & Active status \\
\hline Barnwell, South Carolina & CNSI & Yes \\
Richland, Washington & USE & Yes \\
Beatty, Nevada & USE & No $^{\mathbf{a}}$ \\
Clive, Utah & Envirocare of Utah & Yes
\end{tabular}

a. Closed January 1, 1993, by order of the State of Nevada.

form and packaging requirements that allow the facility to meet the disposal facility performance objectives of 10 CFR 61 . However, LLW received at all three pre-10 CFR 61 facilities is, in most respects, required to meet $10 \mathrm{CFR} 61$ waste form and packaging requirements for both the "minimum" and "stability" waste form requirements in 10 CFR 61.56(a)(b), respectively. This regulatory requirement is a result of the host State's regulatory agencies' decisions to require the disposal facilities to emulate the operation of a post-10 CFR 61 facility. Consequently, the pre-10 CFR 61 facilities' materials licenses have been amended since the promulgation of 10 CFR 61. Moreover, the WAC established in each facility's materials license are essentially compatible to the waste classification (20.311 and 61.55), waste characteristics (61.56), and other criteria established to ensure that LLW disposal complies with the performance objectives of 10 CFR 61.

\subsection{Future Regulation of Low-Level Radioactive Waste Disposal}

At present, the State regulations governing LLW disposal at existing sites are essentially compatible with the NRC's 10 CFR 61 regulations. There are various license conditions for each facility that are more prescriptive than the basic requirements for waste packaging and waste form in 10 CFR 61. Many of these conditions are intended to "backfit" 10 CFR 61 design and operations requirements to pre-10 CFR 61 disposal facilities. As stated in Section 2.2, most of the existing facilities were not originally developed in accordance with the strict siting and design requirements of 10 CFR 61 .

Facilities developed after $10 \mathrm{CFR} 61$ are subject to a more rigorous review and selection process that, in many cases, is driven by host State regulations that are more prescriptive than those governing the operation of existing facilities. This is especially true for facilities under development in the central and eastern states, where high annual precipitation rates and high groundwater tables pose obstacles toward achieving compliance with the performance objectives of Part 61. Some of these host States include many disposal facility design and operations requirements related to waste acceptance directly in the regulations. In the past, these requirements would only have been included as license conditions, if required at all.

For example, the New York State regulation, 6 New York Code of Rules and Regulations (NYCRR) Part 382, "Regulations for Low-Level Radioactive Waste Disposal Facilities (Certification of Proposed Sites and Disposal Technologies)" Subpart J (Sections 382.80 through 382.99), "Waste Classification and Characteristics" is very prescriptive about waste form and 
packaging. Section 382.81, "Waste Characteristics," contains requirements consistent with the NRC regulation 10 CFR 61.56, with the exception of allowed free liquid. Other parts of 382.81 are compatible with 10 CFR 61.56, including the allowed use of packaging to ensure long-term waste stability.

Effective March 14, 1993, the New York State Department of Environmental Conservation promulgated 6 NYCRR 383, "Regulations for Low-Level Radioactive Waste Disposal Facilities" (Design, Construction, Operation, Closure, Post-Closure, and Institutional Control). Section 3838.3 details wastes that are excluded from the disposal facility unless they are incinerated or stabilized by another method approved by the department. Section 383-8.4 discusses LLW inspection and testing, acceptance requirements, and treatment of unacceptable waste forms, and Section 383-8.5 discusses requirements for treatment and storage of waste prior to disposal.

The following requirements of Section 383-8.4(b) are applicable to the inspection and testing of waste:

- The permittee must develop and implement a waste inspection and testing program designed and implemented to provide:

- An effective deterrent to the shipment of unacceptable waste to the land disposal facility

- Reasonable assurance that waste accepted for disposal meets the requirements of the permit, this Part and Parts 381 and 382 of this Title.

- The waste inspection and testing program must include the surveying of all waste packages with appropriate radiation detection instruments to detect surface contamination and to measure radiation levels.

- The waste inspection and testing program must include the $\mathrm{x}$-raying of all Class $\mathrm{A}$ waste packages, except those in casks, to detect waste and waste forms that are not in compliance with this Part and Part 382 of this Title. The permittee must videotape all $\mathrm{x}$-ray inspections and retain all videotapes as required by Section 382-13.2 of this Part.

- The waste inspection and testing program must include the following procedures:

- $\quad$ Monitoring, sampling, and analysis of waste packages selected as required by Section 383-84(b)(5) of this Part, to verify the information presented on the manifest and to determine compliance with the applicable requirements of this Title and the permit.

- Other nondestructive testing and inspection methods to be applied to waste packages selected as required by Section 383-8.4(b)(5) of this Part. These may include measures such as comparing the weight of the waste package with the waste description on the manifest, comparing waste characteristics with information about generator's processes, and isotopic gamma analysis of external radiation fields. 
- The procedures described in Section 383-8.4(b)(4) of this Part must be selected and applied to waste received, as appropriate for the waste, considering its class, form, packaging, and any other relevant characteristics and the requirements in Section 382.13 of this Title to keep radiation exposures during operation as low as reasonably achievable (ALARA).

- At least one of the procedures described in Section 383-8.4(b)(4) of this Part must be applied to waste received at the land disposal facility, at the following frequency:

- $\quad$ One waste package from at least one shipment in any week during which waste is received

- One waste package from at least one out of every five shipments received

- One waste package from each shipment received from any person who has shipped unacceptable waste to the land disposal facility within the past 12 months

- $\quad$ One waste package from each of the next three shipments received from any person who ships unacceptable waste to the land disposal facility.

The following requirements of Section 383-8.4(c) detail the WAC that are applicable to the acceptance of waste.

- The permittee must not accept waste for disposal unless it is authorized by the permit to accept such waste, it has adequate treatment, storage, and disposal capacity available, and the following criteria are met:

- The waste must conform to the information set forth on the manifest accompanying the waste shipment.

- The waste package must be in compliance with all applicable State and Federal regulations for the transport of radioactive material and hazardous waste, including Parts 364, 372, 381, and 382 of this Title.

- Waste must meet the requirements of Section 382.81 of this Title, unless the permittee, in accepting the waste for disposal agrees to treat and/or repackage it to meet the requirements of Section 382.81 of this Title.

- Waste containing iodine-129 must be accompanied by the results of analyses authorized by the department that were performed to determine the activity of iodine- 129 contained in the waste.

- For the disposal of waste authorized by the department in accordance with Section 382.83 of this Title, the waste meets the requirements of that authorization. 
- Only waste containing or contaminated with radioactive material may be disposed of in disposal units at the land disposal facility.

- At the time a shipment or any part of a shipment is accepted for disposal, the permittee must date the manifest, sign the appropriate certification on the manifest, give the copy to the transporter, and obtain the remaining copies of the manifest from the transporter.

- Within one week of acceptance of a shipment or any part of a shipment, the permittee must send one signed and dated copy of the manifest to the radioactive materials licensee who last possessed the waste and transferred the waste to the permittee.

- Within 15 business days of acceptance of a shipment or any part of a shipment, the permittee must send a legible copy of the signed and dated manifest to the New York State Department of Environmental Conservation, Bureau of Radiation, Division of Hazardous Substances Regulation, 50 Wolf Road, Albany, New York, 12233-7255.

- Upon acceptance of the waste, the permittee must clearly label each waste package with a unique identification number, which must be used to identify the package throughout the storage, treatment (if any), and disposal operations. The number must be used in all records pertaining to waste packages required by Subpart 383-13 of this Part and in the tracking system required by Section 383-8.6(a)(2) of this Part.

- Following receipt and acceptance of a shipment of waste, the permittee must record the following information:

- The date that the shipment was received at the disposal facility

- The date of disposal of the waste

- A unique shipment manifest number

- The location of disposal at the disposal site

- The volume of any pallet, bracing, or other materials that are included with waste shipments, or are generated from onsite activities, and that are disposed of as contaminated or suspect materials

- The containment integrity of the waste disposal containers as received

- Any discrepancies between materials listed on the manifest and those received

- Any evidence of leaking or damaged packages or radiation or contamination levels in excess of limits in Part 381 of this Title

- A brief description of any repackaging operations of any of the waste packages included in the shipment 
- $\quad$ Any other information required by permit.

- The permittee must store the information described in Section 383-8.4(c)(7) of this Part in the computer recordkeeping system required by Section 383-13.2(h) of this Part.

- The permittee must not accept waste or NARM waste from a generator or broker unless the generator of the waste has submitted a waste minimization statement to the permittee. The waste minimization statement must contain an analysis of the potential for reducing the generation of waste and, based on this analysis, a proposed program to reduce the volume and activity of waste produced by the generator. The waste minimization statement must include:

- An identification of the amount and type of wastes generated

- For each waste stream, an identification of the source of these wastes

- An analysis of technically and economically feasible waste reduction techniques

- A waste minimization program and schedule for implementing the feasible waste reduction techniques.

The following requirements of Section 383-8.4(d) are applicable to the disposal of waste found unacceptable for disposal at the land disposal facility.

- The permittee must return waste not acceptable for disposal to the waste generator or processor, or reprocess and/or repackage it into an acceptable form. Waste returned to the generator must meet the requirements of Federal and State transportation laws and regulations.

- The permittee must isolate waste awaiting reprocessing, repackaging, or return to the generator or processor from all other waste on the site.

- The permittee must report the receipt of all unacceptable waste in accordance with Sections 383-13.3 and 383-13.4 of this Part. 


\section{WASTE GENERATORS' CERTIFICATION PROGRAMS}

LLW disposal facilities rely on waste generator certification programs. This section discusses the various types of LLW generators, the typical waste forms being generated, and the measures taken to meet disposal facility WAC. Generator certification programs contain verifiable audit checkpoints necessary to demonstrate compliance with the WAC. The supporting data required for verification are normally found at the generator facility. LLW disposal facilities will perform random sampling on incoming shipments, whereas the generator certifies each package according to the programs discussed in this section.

\subsection{Types of Low-Level Radioactive Waste Generators}

Sources of commercial LLW may exist wherever radioactive materials are handled or processed, and can be categorized into two types:

- Industrial and institutional sources, including manufacturers, test and research laboratories, hospitals, and academic institutions

- Commercial nuclear fuel cycle sources - production facilities for uranium hexaflouride, nuclide enrichment, and fuel fabrication, nuclear power plants, spent fuel storage facilities, and fuel cycle facilities undergoing decontamination and decommissioning.

\subsubsection{Low-Level Radioactive Waste Characteristics}

Typically, waste from conversion, commercial nuclide enrichment, and fuel fabrication facilities contain the radionuclides in the uranium decay chain as the predominant constituents. Industrial and institutional waste contain a broader spectrum of radionuclides in small quantities, with H-3, C-14, Co-60, Tc-99m, and Cs-137 representative of constituents from medical, manufacturing, or test operations. Nuclear power plants and spent fuel storage facilities produce LLW containing primarily activation products, fission products, and transuranic elements. At present, only very small amounts of DOE LLW are disposed at commercial LLW sites.

\subsubsection{Summary of Low-Level Radioactive Waste Forms}

The physical form of the LLW is the primary consideration in selecting treatment and packaging alternatives for the material. These physical forms are:

- $\quad$ Radioactive gases

- $\quad$ Liquid LLW streams

- Dry solid LLW.

Radioactive gases are often treated to remove contaminants, with the resultant waste generated by the treatment process (for example, filtration, scrubbing, absorption) falling into one of the other categories. The decontaminated gas is subsequently discharged directly to the environment. 
Liquid LLW streams are fluids with relatively low concentration of solids, generally less than $1 \%$ suspended solids. The "liquid" designation, however, may be applied to fluids containing up to $10 \%$ suspended solids, which are categorized as slurries. The predominant liquid LLW forms include the following waste streams:

- Decontamination solutions generated from decontamination of building and equipment surfaces. These solutions are either water-based, containing suspended solids and small quantities of chemicals and detergents, or chemical-based, containing strong detergent agents that are usually also chelating agents.

- Chemical regenerative solutions produced from the regeneration of organic ionexchange media, such as demineralizer beds and resin beds.

- Contaminated oils produced by the oil/water separators used to treat floor and equipment drains, from hydraulic scrubbers used in system piping, and from used oil from reactor coolant pumps.

- Liquid scintillation fluids generated as organic solvents (for example, toluene, xylene) in liquid scintillation counting operations.

- Miscellaneous liquid wastes produced from various sources such as laundry waste, discharges from equipment and floor drains, process and steam condensate, steamcondensate cooling water discharge, and rinse water from cleaning and purging operations.

- Semisolids or wet solids produced from the treatment of liquid waste, or as thick (high solids content) slurries from a materials processing operation (for example, tailings). This waste form includes evaporator bottoms, expended filter cartridges, biological waste (such as animal carcasses, animal bedding, excreta, vegetation, culture media), and miscellaneous slurries.

Dry solid LLW includes the following:

- Contaminated equipment and materials, inclusive of nuclear power plant equipment (for example, piping sections, valves, and motors) that has been taken out of service, building material from decommissioning and remediation operations, and radiologically contaminated soil from remediation operations.

- Bulk trash, categorized as compactible or noncompactible, and combustible or noncombustible. For example, clothing, rags, plastic, and paper products are both compactible and combustible, whereas construction material, tools, and piping are generally noncompactible and noncombustible.

- Irradiated hardware that consists of plant components activated by exposure to a neutron flux and then removed from service. 


\subsection{Generator Compliance with Waste Acceptance Criteria}

Each generator certification program has an objective of meeting the applicable regulations regarding waste classification, treatment, and packaging. Specific procedures are developed to ensure that each waste stream is handled properly with the goal of WAC compliance as the primary objective. Each regulatory requirement has a performance criteria or standard that must be met. Generators have developed their own unique programs tailored to address their waste volume reduction needs. This section discusses the typical program elements found in a generator compliance program.

\subsubsection{Waste Classification}

The acceptance criteria established by the NRC and used at commercial LLW disposal facilities, particularly the LLW classification system, identify the need for collection and segregation of LLW prior to either processing or packaging of the waste. The LLW classification system defines three classes of waste for which states/compact regions are responsible: Class A, Class B, and Class C. Each waste class has established maximum concentration limits for individual radionuclides, with the limits increasing from Class $\mathrm{A}$ to $\mathrm{C}$. Class $\mathrm{A}$ places only minimum requirements on waste form and characteristics. Classes $\mathrm{B}$ and $\mathrm{C}$ set more stringent requirements on waste form and characteristics to ensure physical stability after disposal, such as the requirement that the waste must remain stable and recognizable for 300 years. Proper waste classification is a compliance verification item that is verified by reviewing the generator procedure and verifying that supporting documentation exists.

\subsubsection{Waste Treatment}

The waste form is usually treated to reduce the volume of waste requiring disposal, or to change the waste form, and/or to separate the radioactive components from the nonradioactive component in the waste stream. Treatment of LLW generally takes place when it is necessary to satisfy regulatory requirements or if treatment improves the overall cost-effectiveness of disposal.

LLW treatment produces a waste stream that has a smaller volume and higher concentration of radioactivity than the original waste, and a second stream of sufficiently lower radionuclide concentrations than the original waste to permit release or reuse. The U.S. nuclear industry, particularly the utilities that generate large volumes of LLW, are increasingly using volume reduction treatment techniques to reduce processing and disposal costs.

WAC should ideally be uniform for each LLW disposal facility. Waste acceptance at a facility should be based on review of accompanying shipment documentation that includes the following characterization information:

- A physical description of the waste

- Waste volume and weight

- $\quad$ Radionuclide identity and quantity 
- Total radioactivity

- Principal chemical form

- Solidification agent, if any

- Absence of free-standing water

- Waste class.

\subsubsection{Waste Packaging}

The shipper is responsible for ensuring the adequacy of the waste packaging, and for ensuring that the carrier is licensed and follows proper procedures, and that the disposal facility operator is certified to receive the packages. Confirmation that these responsibilities are being met is embodied in the radioactive waste manifest that accompanies each shipment of waste. An auditor can verify the execution of each of the waste packaging steps while reviewing the generator's procedures and supporting records such as the radioactive waste manifest. The manifest contains the following information, as a minimum:

- DOT proper shipping name, hazard class, and identification number for the material (from 49 CFR 172.10); and NRC certificate identification, if relevant

- Shippers certification that the waste package has been properly prepared for transport

- Description of the chemical and/or physical form of the waste

- Name of each radionuclide and the activity of the radioactive material in each package(s)

- Type of packaging and transport index assigned to each package

- $\quad$ Category of label applied to each package

- Waste form and classification (from $10 \mathrm{CFR} 61$ ).

Most LLW is shipped as LSA Exclusion Use, for which labeling and marking of individual packages are not required. However for nonexclusive use shipments, shippers must affix warning labels on two opposite sides of the package prior to loading the packages on the transport vehicle. Three different warning labels are used that indicate the external radiation level and the specific handling procedures to be used. These labels are:

- Radioactive - White I

- $\quad$ Radioactive - Yellow II

- $\quad$ Radioactive - Yellow III. 
Additionally, the shipper must mark each package with applicable DOT package specification, proper shipping name (from 40 CFR 172.101 list of hazardous materials), and identification number, the appropriate package Type (A or B), and the gross weight (if greater than $110 \mathrm{lb}$ ).

The maximum permissible dose rate at any point on the external surface of any package of radioactive materials cannot exceed $200 \mathrm{mrem} / \mathrm{hr}$ or $10 \mathrm{mrem} / \mathrm{hr}$ at $1 \mathrm{~m}$ from the surface (49 CFR 173). Shipment of waste by "exclusive use" vehicle allows for slightly higher radiation levels: $1 \mathrm{rem} / \mathrm{hr}$ at the package surface for a closed transport vehicle, $200 \mathrm{mrem} / \mathrm{hr}$ at the external surface of the vehicle, $10 \mathrm{mrem} / \mathrm{hr}$ at $2 \mathrm{~m}$ for the vehicle surface, and $2 \mathrm{mrem} / \mathrm{hr}$ in any position of the vehicle that is occupied by a person (transport worker). All packages are wipe tested to ensure that any removable contamination on a package does not exceed applicable limits set forth in 49 CFR 173.

To ensure compliance with the waste classification requirements of $10 \mathrm{CFR} 61$, the NRC requires its licensees, prior to packaging LLW for shipment, to:

- Classify the waste in a consistent manner

- Establish an onsite compliance program specific to that facility that considers the various radiological and other diverse characteristics of the different waste streams generated by the facility

- Adhere to an objective of achieving measured or inferred radionuclide concentrations accurate to within a factor of 10 .

There are four basic methods to characterize packaged wastes either individually or in combination by licensees:

- Materials accountability

- Classification by source

- Conversion factor technique using a calibration curve

- $\quad$ Direct measurement of individual radionuclides.

The conversion factor technique is used by many industrial and fuel cycle facilities and involves the conversion of external gross gamma radiation readings to an estimated curie content of the package using a calibration curve specific to the type of material in the package.

The typical procedure at the shipper's facility for loading of the waste in drums, the most common form of LLW packaging, includes the following steps: 
1. Inspect each drum prior to use for obvious defects, such as holes and split seams.

2. Place drums on pallets at the drumming station and load with waste material. All liquid wastes are immobilized prior to closure of the drum.

3. Place the lid with the gasket on the drum to ensure that there is a good fit between the drum and the lid.

4. Attach the bolt ring to the drum, engaging both the lid and rim of the drums. Screw in the bolts, attach the nuts, and screw it on tight.

5. Reinspect the drum for any defects.

6. Affix the appropriate marking or label to the drum.

7. Weigh the drum and record the weight on the label affixed to the drum. Also, record the assigned "container number" on the drum.

8. Perform a radiation and contamination survey of the external surface of the drum to validate that the radiation level on the external surface does not exceed $200 \mathrm{mrem} / \mathrm{hr}$ and that the level of removable radioactive contamination is kept ALARA. The results of the survey are to be recorded and kept on file. If ALARA levels are not achieved, decontaminate the external surface and repeat the survey.

9. Determine the activity level of the drum (using the conversion factor technique).

10. Using a fork lift, move the pallet with the drum on it to the temporary storage area and record the location of the drum.

An auditor can use the shipper's procedure to verify that each step or similar step is conducted prior to loading a LLW shipment to the disposed facility.

\subsubsection{Summary of Generator Waste Forms}

10 CFR 61.56 details the minimum waste form characteristics that must be met for any LLW disposed in near-surface facilities. These characteristics include the use of biodegradationresistant packaging and limitations on liquid content. Liquids must have absorbent material capable of absorbing twice the liquid volume. The LLW waste must be free of explosive material or material that may react explosively with water. Toxic gases, vapor, or fumes must not be produced by the waste. The waste must not be pyrophoric. Gaseous waste must contain less than $100 \mathrm{Ci}$ per package and have an associated pressure of less than 1.5 atmospheres at $20^{\circ} \mathrm{C}$. Any hazardous, biologically pathogenic, or infectious material must be treated prior to disposal. Several of these general requirements are enhanced by the host State and disposal site operator's license conditions, resulting in more restrictive acceptance criteria, as detailed in Section 2 of this report. Section 6 of this report contains system descriptions of the state-of-the-art technology available for verifying waste form compliance. 
Class B and Class C wastes are required to be structurally stable to reduce the likelihood of slumping and failure of the disposal unit cover leading to contact of infiltrating water and the waste. Criteria defining this requirement are given in the NRC's "Branch Technical Position on Waste Form." The waste class distinction is predicated on both long- and short-lived radionuclides contained in the waste. If segregated from other waste, there are no supplemental stability requirements for Class A waste. However, if Class A waste is disposed with Class B and Class $\mathrm{C}$ wastes, the Class $\mathrm{A}$ waste must be structurally stable.

\subsection{Programs for Verifying Generator Compliance with Waste Acceptance Criteria}

Most large generators of radioactive waste, such as commercial nuclear utilities, have a variety of programs, procedures, equipment, and instrumentation to verify compliance with disposal facility WAC. These programs and procedures cover the classification, solidification, packaging, survey, storage, and transportation of LLW from the generator site to the disposal facility. The generator programs normally incorporate the WAC requirements of the specific disposal facility to which the waste is being shipped. Incorporating WAC requirements of the specific disposal facility significantly reduces the likelihood that waste shipped to a disposal facility would not meet the WAC.

Examples of commercial and institutional generator LLW acceptance verification programs are discussed in the following subsections.

\subsubsection{Nuclear Utility Low-Level Radioactive Waste Verification Programs}

The programs and procedures used by nuclear utilities range from process control programs (PCPs) to the final quality control (QC) inspection of the waste prior to shipment. Listed below are some of the in-house or vendor incorporated procedures employed by Consolidated Edison Power Company (ConEd) to verify that LLW generated at Indian Point Units 1 and 2 complies with the WAC of the LLW disposal facility. These in-house procedures may incorporate vendor procedures, equipment, and processing methodologies of vendors who may provide solidification services for processing waste such as filters, sludges, and ion exchange resins. The following is a list of procedures used by ConEd to verify WAC:

- Consolidated Edison Corporate Instruction CI-240, Supplement 1, "Quality Assurance Program for Radioactive Material Packages and Quality Control Requirements for Radioactive Waste Classification and Characterization (Form)"

- Chem-Nuclear Systems, Inc. (CNSI) Procedure SD-OP-003, "Process Control Program for CNSI Cement Solidification Units"

- CNSI, Procedure SD-OP-026 "Process Control Program for Cement/Oil Solidification"

- CNSI, Operating Procedure SD-OP-048, "In Situ Solidification of Suspended Objects"

- CNSI, Operating Procedure SD-OP-050, "Mobile Cement Solidification" 
- RW-SQ-4.000, "Shipment Final QC Inspection"

- RW-4.001, "Container Control and Accountability"

- RW-Q-4.006, "10 CFR 61 Sampling Program"

- RW-SQ-4.007, "Process Control Program (PCP)"

- RW-SQ-4.011, "Radman Program Operation"

- RW-SQ-4.101, "Preparation of Radwaste for Storage or Shipment"

- RW-SQ-4.104, "Classification of Radioactive Materials"

- RW-SQ-4.106, "Shipment of Radwaste"

- RW-SQ-4.202, "Operation and Dewatering of Radwaste's Demineralization System."

3.3.1.1 Waste Stabilization-Process Control Program. Commercial nuclear utilities use process control programs to provide reasonable assurance that processed waste has been completely solidified and is absent of free-standing water prior to shipment offsite and subsequent land disposal. At ConEd's Indian Point II Station, solidification services for processing waste, such as filters, sludges, and water cleanup resins, are currently provided by a contractor.

The vendor's process control program is implemented to ensure that the waste is completely solidified and absent of free-standing water, and is subject to the approval of the Station. The Station's in-house procedures incorporate vendor procedures, equipment, and processing methodologies. Necessary precautions are detailed in the vendor process control program and the utility procedure for each type of waste to be processed. Only waste that falls within the boundary conditions of the vendor's topical report qualification tests is solidified to meet 10 CFR 61 Class $B$ and C stability requirements.

Equipment and instrumentation used by the vendor must be designated in the vendor's PCP and the utility procedure for each type of waste to be processed. The vendor must furnish the utility with a copy of its NRC-approved 10 CFR 61 waste form topical report. ConEd's in-house procedures have specific stipulations regarding the vendor's topical report; among them is the fact that a topical report that is under review should not be used unless written assurances are given by the disposal site of waste acceptance, and the status of the NRC topical report is obtained.

The radioactive waste supervisor or his designee is responsible for management verification of vendor acceptability, and accomplishes this task by performing the following tasks:

- Verifying that contracted services meet ConEd's standards and specifications

- Reviewing the vendor's PCP, operating procedures, and proposed contractual agreements, and advising the appropriate management as to their adequacy 
- Retaining vendor-supplied documentation for NRC inspection and review

- Monitoring vendor operations to ensure compliance with ConEd practices and procedures, as well as with the contractual agreement

- Verifying documentation of vendor acceptability on the Checklist For Vendor PCP.

In order for a solidification vendor to be qualified, the following sample Vendor Qualification Checklist must be completed by the vendor.

\section{Vendor Qualification Checklist}

Is the vendor able to:

Provide a process control review program approved or under review by NRC and the disposal site licensee.

Demonstrate the ability to meet:

- NRC 10 CFR 61.56 waste form standards, including the standards related to HICs

- Disposal site specifications for solidified liquid

- DOT shipping regulations

Provide the following for review and evaluation:

- A general description of the laboratory mixing of a sample of the waste to arrive at process parameters prior to commencing the solidification process.

- A general description of the solidification process, including the type of solidification agent, process control parameters, parameter boundary conditions, proper waste form properties, and assurance that the solidification systems are operated within the established process parameters. Include a discussion of sample mixing, curing as it relates to what the full-scale product will undergo, and waste analysis.

- For cement solidification, a general description of the results of topical report testing to satisfy the qualification test requirements for the new BTP.

- A general description of a sampling program producing at least one representative sample from each batch to ensure solidification and the action to be taken if the sample fails to verify solidification. A batch is defined as any quantity of waste from a single source (for example, a holding tank) that is processed in a single batch, even if it is in several liners. A chemically similar but nonradioactive sample may undergo test solidification if worker ALARA conditions warrant it. 
- The provisions to verify the absence of free liquid in solidified waste. A compressive strength test for PCP test specimens.

- The provisions to reprocess containers of solidified waste in which free liquids are detected.

- If the solidification process is exothermic, the process control parameters that shall be met prior to capping the container. This includes the use of an in situ temperature probe.

- A general description for the treatment of oily wastes that are to be transported offsite for burial.

- As appropriate, a sketch of the process systems.

- A statement that ALARA considerations were addressed in all phases of the solidification process.

- A description of the dewatering technique and control procedures. If a HIC is used, this should include a PCP to ensure that free-standing liquid requirements are met $(0.5 \%$ in a steel liner or $1.0 \%$ free-standing liquid in a $\mathrm{HIC})$.

- A description of provisions to reprocess wastes through the dewatering system if excess free water is observed.

- Guidance to the utility for surveillance specimen storage and testing. This archive testing shall be described in detail.

The waste stream samples are deemed acceptable once the Checklist For Vendor PCP is complete. If the end product of sample solidification indicates a uniform, dry, free-standing monolith, and the end product resists penetration when probed with a firm object, then the solidification process is deemed complete. The checklist is comprehensive to a wide variety of waste forms and, therefore, must be tailored to meet the specific WAC requirements pertaining to a generator's waste stream.

Table 3-1 lists a series of qualification tests used by ConEd in its PCP to satisfy the qualification test requirements for the new BTP. Test methods are compared to the original BTP (NRC 1983) requirements for cement stabilization of waste with requirements contained in the new BTP (NRC 1991) in Table 3-1. The process control program used by ConEd and other commercial utilities plays 
Table 3-1. ConEd Indian Point Station radioactive waste cement BTP comparison.

\begin{tabular}{|c|c|c|c|}
\hline Qualification tests & $\begin{array}{l}\text { Test methods } \\
\text { (unchanged) }\end{array}$ & $\begin{array}{c}1983 \text { BTP } \\
\text { cement stabilization guidance }\end{array}$ & $\begin{array}{c}\text { January } 24,1991, \text { BTP } \\
\text { cement stabilization guidance, Appendix A }\end{array}$ \\
\hline Compressive strength & ASTM C39 & $>60 \mathrm{psi}$ & $>500$ psi mean "recommended" \\
\hline Radiation stability & Gamma radiation & $>60$ psi after $10+8$ rads & $\begin{array}{l}>500 \text { psi mean faster testing at } 10+8 \text { rads } \\
\text { (resins or organics only) }\end{array}$ \\
\hline Biodegradation & ASTM G22, G21 & $\begin{array}{l}>60 \text { psi plus no growth, or } \\
>60 \text { psi plus growth rate }<1 .\end{array}$ & $\begin{array}{l}\text { No growth plus }>500 \text { psi mean } \\
\text { (resins or organics only) }\end{array}$ \\
\hline Leachability & ANS 16.1 & $\begin{array}{l}\text { Leach index }>6,90 \text { day freshwater } \\
\text { and saltwater }\end{array}$ & Leach index $>6,5$ days, worst leachant \\
\hline Immersion & & $\begin{array}{l}>60 \text { psi after } 90 \text { days freshwater } \\
\text { and saltwater }\end{array}$ & $\begin{array}{l}90 \text { days worst leachant } 28 \text { day cure plus } \\
>500 \text { psi mean or }>75 \% \text { of pre-test resins }- \\
\text { add } 7 \text {-day test on } 180 \text {-day cure }\end{array}$ \\
\hline Thermal cycling & ASTM B553 & $>60$ psi after 30 cycles $60 /-40^{\circ} \mathrm{C}$ & $>500$ psi mean after 30 cycles $60 /-40^{\circ} \mathrm{C}$ \\
\hline Free liquid & ANS 55.1 & $<0.5 \%$ volume & $<0.5 \%$ volume plus $\mathrm{Ph} \geq 9$ \\
\hline Full scale tests & & $\begin{array}{l}\text { Correlate field and laboratory size } \\
\text { samples; field must be homogeneous }\end{array}$ & $\begin{array}{l}\text { Correlate field and laboratory size samples; } \\
\text { field must be homogeneous }\end{array}$ \\
\hline
\end{tabular}


a significant role in ensuring that wastes generated by these facilities are "acceptable" for disposal by land burial as defined in the disposal facility license application and consistent with 10 CFR 61 .

3.3.1.2 Waste Characterization Procedures. Other examples of procedures and programs used to verify the acceptability of waste for disposal are embodied in ConEd's "10 CFR 61 Sampling Program," the "10 CFR Part 61 Radwaste Classification Program," the "Shipment Final QC Inspection Procedure," and the "Radwaste Shipping Manifest Procedure." Each of these programs/procedures is discussed and the methods/equipment and materials used to enact and complete these programs are detailed.

ConEd's 10 CFR 61 sampling program is used to monitor radionuclide trends in radioactive waste streams at Indian Point Units 1 and 2. The procedure is applicable to obtaining and analyzing radioactive waste samples for the purpose of compliance with waste classification requirements of 10 CFR 61, "Licensing Requirements for Land Disposal of Radioactive Wastes." Waste classification compliance is ensured by using a scaling factors method to determine radionuclide concentrations. Details on equipment and materials necessary for the use of this sampling program are:

- Gamma spectral multichannel analyzer

- Sampling bottles

- Sample packaging and containers

- Outside laboratory services for radiochemistry analysis.

This sampling program includes a radionuclide behavior analysis for the nuclides measurable by the plant's gamma spectroscopy equipment. The behavior analysis is intended to trend radionuclide behavior under various plant/system operating modes and conditions. Difficult to measure radionuclides, such as transuranics, beta-emitters and hard-to-resolve gamma-emitters are analyzed by special radiochemical counting techniques. These samples are shipped to specialized outside laboratories for analyses. The selected laboratory must have experience performing 10 CFR 61 compliance analyses. The experience requirement is met by a laboratory showing a history of analytical capability in performing radiochemical analyses using techniques recommended by NRC.

At specified intervals and locations, samples are taken of the reactor coolant system (RCS), RCS filter media, spent resin storage tank resin, disposable radioactive waste resins, dry active waste, radioactive waste sludge, and a variety of miscellaneous wastes. A gamma spectrum analysis of each sample is performed under the stipulations provided in the procedure and the results reported in units of $\mu \mathrm{Ci} / \mathrm{cc}, \mu \mathrm{Ci} / \mathrm{gm}$, or $\mu \mathrm{Ci}$ per unit, as applicable to the technique used. Results obtained from an outside laboratory should include all radionuclides listed in 10 CFR 61.55, Tables 1 and 2.

Each sample prepared for shipment subsequent to laboratory analysis must adhere to the following requirements: 
- Labeling with the following:

- $\quad$ Plant name and address

- Sample location and name

- Sample date and time

- Sample number

- Packaging liquid samples such that an inner sealed bottle is packaged with sufficient absorbent material to absorb at least two times the liquid volume and sealing against leakage

- Orienting the liquid container with the capped opening in an upright position in the package

- Marking the outer package with orientation labels (arrows pointed in the direction of the upright liquid container and stating "This Way Up")

- Mailing instructions about the required analysis and sensitivities for each sample being sent to the outside laboratory

- Labeling, marking, surveying, etc., for a radioactive materials shipment according to RW-SQ-4.107 and RW-SQ-4.100.

After the analytical results have been received from the offsite laboratory, a 10 CFR 61 laboratory sample analysis of the results is performed. This analysis compares in-house sample name and size to that sent to the laboratory for a given waste stream, the in-house gamma (easy to measure) nuclide concentration results to the offsite vendor results for the same nuclides, and vendor percent uncertainties to results for radionuclides included on Tables 1 and 2 of 10 CFR 61.55. Detectable results shall be available on the offsite laboratory results for the following nuclides: Co-60, Cs-137, Fe-55, Ce-144, H-3, I-129, and C-14.

The analysis results, coupled with the offsite laboratory analysis, provide additional assurance that the waste streams prepared for shipment and disposal meet the WAC of the disposal facility for which they are destined. These data can be reviewed by an auditor during generator inspections.

3.3.1.3 Waste Classification Procedures. ConEd procedure RW-Q-4.103 provides detailed instructions for the 10 CFR 61 waste classification of LLW to be shipped to commercial near-surface disposal facilities. This procedure satisfies the waste classification requirements of 10 CFR 61.55 and provides a manual method to perform this classification. ConEd also has a computer program (Radman Computer Program) that performs this task automatically. 
Survey data sheets, radioactive waste storage logs, and the results of recent waste stream sampling are the materials and equipment needed to perform the waste classification. Classification of radioactive waste pursuant to 10 CFR 61 consists of three basic steps:

- Determine easy-to-measure nuclide concentrations in the solid waste and select key nuclides. (Section 5 of this report includes a discussion on suitable instrumentation sensitivity and compatibility.)

- Use key nuclides to determine difficult to measure nuclide concentrations in the solid waste using scaling factors.

- Compare the concentrations of identified nuclides with the limits set by Table 1 and Table 2 of 10 CFR 61.55 to determine the classification.

Instructions and requirements are listed to determine the following waste characterization compliance items:

1. 10 CFR 61 worksheet input data.

2. Radionuclide concentrations for gamma-emitters, including low specific activity (LSA) crates or drums containing dry active wastes (DAW), and liners or containers containing non-DAW wastes.

3. Concentrations for radionuclides, including step-by-step package instruction and the conversion of TRU concentrations to nanocuries per gram.

4. Concentration of nuclides with less than a five-year half-life.

5. The concentration of alpha-emitting TRU nuclides with a greater than five-year halflife. From these determinations, the Part 61 waste classification(s) of these wastes are made. Examples of the classification worksheets and other materials used in this procedure are provided in Attachment 2 of Appendix A.

3.3.1.4 Final Inspection Procedures. ConEd Procedure RW-SQ-4.000, Rev. 9, "Shipment Final QC Inspection," is used to provide assurance that Indian Point Units 1 and 2 are in compliance with all applicable plant procedural and administrative guidelines, State and Federal regulations, and burial site criteria with regard to the classification, form, packaging, loading, transportation, transfer, and disposal of radioactive materials. This procedure is the final QC inspection providing supervisory verification of compliance prior to vehicle or cask closure and the subsequent departure of the shipment, and is applicable to all outgoing radioactive wastes. The intent of the procedure is to ensure that all requirements of the NRC and DOT regulations regarding protection of the health and safety of the public during the transport of radioactive material over public highways are met. 
The radioactive waste supervisor and an independent $\mathrm{QC}$ inspector are responsible for conducting the final inspection procedure. No special equipment or materials are needed for this procedure.

The shipment compliance verification record is established to provide a functional checklist for each phase of the final inspection. The steps for the final shipment inspection are:

- Prepare documentation

- Conduct surveys

- $\quad$ Package and load

- Transfer and ship.

The QC inspection procedure consists of the following components:

- Obtain current shipment compliance verification record

- Complete the shipment compliance verification record cover sheet

- Gather the prerequisite documentation

- Organize the shipment documentation

- Perform container inspection

- Perform vehicle inspection

- Review the records and file

- Observe ALARA compliance

- Check vehicle departure

- Check notification requirements

- Observe incoming radioactive material verification.

At ConEd, the acceptable performance of the procedure is denoted by the completion of all prerequisite procedures and Attachments 8.1 and 8.2 in Appendix A.

3.3.1.5 Shipment Documentation Procedures. Another important procedure used by ConEd and other commercial utilities to ensure that radioactive waste shipped for land disposal meet the stipulated WAC is the "Radwaste Shipping Manifest." This procedure is applicable to the shipment of solid radioactive waste transported in exclusive (sole) use vehicles loaded by Indian Point Station and off-loaded by the disposal facility. Its purpose is to ensure that the 
preparation of radioactive waste shipment manifest forms comply with current regulatory and disposal facility requirements.

The following equipment and materials are required for this procedure:

- Current copies of the radioactive Shipment Manifest Form from CNSI and USE

- CNSI Radioactive Shipment Manifest or USE Radioactive Waste Shipment and Disposal Manifest as applicable

- Radioactive waste storage logs

- Survey data sheets for all packages or containers to be shipped

- Waste and shipping classification worksheets completed in accordance with ConEd procedures TS-Q-4.103 and TS-SQ-4.101.

Attachment 8.1 in Appendix A illustrates the requirements and instructions used to ensure that waste shipped from commercial utilities in general and, more specifically, the Indian Point Stations 1 and 2, are in compliance with WAC of the targeted disposal facility.

3.3.1.6 Utility Verification Program Summary. The confluence of programs and procedures/equipment/methods provide assurance that DOT and NRC regulations pertinent to the processing, characterization, classification, shipment, and disposal of LLW are met. Adherence to these programs and procedures and their inherent testing and qualification methods, procedures, and guidelines provides the greatest assurance that LLW shipped from large generator sites meet the WAC of the selected commercial disposal facility.

Other commercial utilities contacted (i.e., Niagara Mohawk, Northeast Utilities, and Texas Utilities) have programs and procedures/equipment for the verification of WAC similar to those detailed for ConEd. These procedures for the respective commercial generators are, of course, tailored and specific to the LLW disposal facility to which the waste is shipped.

\subsubsection{Institutional Low-Level Radioactive Waste Verification Programs}

The institutional programs consist of universities and research centers. The LLW verification methodologies previously described in this section are currently being implemented at most of the universities that have large-scale nuclear medicine programs or reactor curriculums. The management structure and administrative depth is limited because of budgetary constraints. A typical institutional program includes the following scenario.

Radioactive materials shipments from universities are normally the responsibility of the originating department; all outgoing shipments of radioactive material are packaged with guidance from the University Radiation Control Office (RCO). Verification of the adequacy of packaging, monitoring of dose rates, and preparation of shipping documents are performed by RCO personnel. All outgoing shipments of radioactive materials are required to be processed through the RCO. 
To dispose of radioactive waste, it must be segregated in the laboratory according to waste type and radionuclide, and accumulated and packaged in containers in accordance with strict guidelines specified by the RCO. The waste is picked up by RCO personnel on an "as requested" basis, three times per week. Each item is checked for proper packaging, identification of radionuclides, and the presence of radionuclide activity data and chemical form data before an item is accepted by the RCO. The item is logged into the waste inventory program and assigned to a waste disposal category.

Waste items containing radionuclides with half-lives less than 120 days are held in storage at least 10 half-lives or until they have decayed to background. The items are then removed for conventional disposal or released to Risk Management and Safety, as appropriate. Storage areas are becoming more common throughout the university environment. Institutional facilities have used radioactive waste brokerage firms as a disposal option. Brokerage firms assume liability of the LLW once the package has been opened for processing purposes.

The methods for verifying compliance with the disposal site WAC at institutional facilities are similar to other generator facilities; however, the primary difference is that institutional facilities have additional process knowledge which can reduce the analysis requirement per waste stream. 



\section{A SUMMARY OF DISPOSAL FACILITIES' PROGRAMS TO VERIFY COMPLIANCE WITH WASTE ACCEPTANCE CRITERIA}

This section summarizes the LLW facility operating practices that are based upon the WAC references in Section 2, Table 2-1. The LLW facility operators were contacted for copies of their operating procedures. Each procedure relevant to verification of the facilities' WAC was summarized. The objectives of the disposal facility verification programs are also highlighted in this section.

With the exception of the Envirocare facility, all of the currently licensed LLW disposal facilities were initiated prior to 10 CFR 61 regulations. A series of amendments to the disposal facilities' materials licenses since 10 CFR 61 have established WAC in each facility's materials license which are essentially consistent with the waste classification required in 10 CFR 20.311, waste characteristics required in $10 \mathrm{CFR} 61.56$, and other criteria related to performance-driven LLW disposal.

The waste disposal facilities have guidance for developing a program for receipt and inspection of LLW. Also NUREG-1200, Low-Level Waste Disposal Licensing Program, published in 1987, provides a standard review plan for waste receipt and inspection programs. The intent of the standard review plan is to evaluate a license application's adequacy to meet the requirements of $10 \mathrm{CFR}$ 61. The following license requirements are included in the regulatory evaluation criteria:

- Examination of shipping documents

- Visual check of the waste package

- Survey for removable contamination and external radiation levels

- Verification of waste classification

- Verification of minimum waste form and stability requirements

- Identification of packages requiring remediation

- Evaluation of the license review findings.

Waste review and acceptance procedures from the Beatty, Nevada and Richland, Washington facilities, and a summary of those procedures from the Barnwell facility were reviewed for their ability to detect deficiencies in WAC listed in Table 2-1. Envirocare is currently licensed to accept naturally occurring radioactive material, and byproduct material defined in 10 CFR 30, so its survey and acceptance procedures do not reflect those of a facility receiving all types of LLW.

The generation, packaging, shipment, and receipt of LLW provides an interrelated relationship of parties for ensuring compliance with WAC. As the waste and its manifest and 
certification is passed from one to the other, the liability for that waste follows, and upon its receipt at the disposal site, all three parties (generator, shipper, and facility operator) are responsible for waste form or container violations. Penalties for repeated violations affect all three parties. The generator can lose facility access and its license, and/or be fined. The shippex: is liable for the same penalties, and may have to bear the cost of return of a nonconforming shipment to the generator. The facility operator may be forced to repackage the waste to meet disposal site criteria, and must bear the cost of temporary operations interrupts, cleanup, or other recovery measures caused by waste form or package nonconformance.

This necessary cooperation promotes a smooth working relationship, which begins with the generator's notification to the facility operator before it is loaded onto a truck for shipment, that the generator proposes to send a waste shipment of a specified volume, weight, package type, and curie content to the disposal facility. When the generator receives written approval from the disposal facility, a licensed shipper takes possession of the waste via a signed manifest and shipper's certification of the content and transports the waste to the disposal facility.

All parties of the transfer are aware of the WAC, DOT requirements, and State or local requirements applicable to the shipment. When a LLW shipment arrives at any of the three operating facilities, a series of incoming verification steps are conducted by the facility manager, health physics technician, or designee. The following incoming verification steps are summarized from the four facility operation procedures.

1. Prior to accepting any waste, shipment inspections are performed to determine if each shipment complies with DOT regulations regarding radiation and contamination levels. A radiological survey is conducted according to an established facility operating procedure.

2. Shipping documents are reviewed to verify compliance with State and Federal requirements. Figure 4-1 includes sample radioactive shipment manifest forms from the Barnwell and Envirocare facilities. Each manifest is reviewed for the following items:

- Completeness and legibility

- A certificate of compliance, if applicable, for specification shipping containers required by 10 CFR 71

- Exclusive-use instructions provided by the shipper to the carrier for shipments consigned as exclusive use

- $\quad \mathrm{DOE} / \mathrm{NRC} 741$ form, if required

- Certification of limited quantity or instruments and articles, if applicable

- The shipment content descriptions do not contain material prohibited by the disposal facility license conditions 
(1) GENERATOR NAME

FACILITY

ADDRESS

\begin{tabular}{ll}
\hline CITY & ZIP \\
\hline
\end{tabular}

CONTACT

EMERGENCY RESPONSE CONTACT:

(2) BIL TO
BARNWELL WASTE MANAGEMENT FACILITY

Operated by CHEM-NUCLEAR SYSTEMS, INC.

PO Box 726, Barnwell, South Carolina 29812 (803) 259.178

RADIOACTIVE SHIPMENT MANIFEST FORM

(3A) RADIOACTIVE WASTE TRANSPORTATION PERMIT NO.

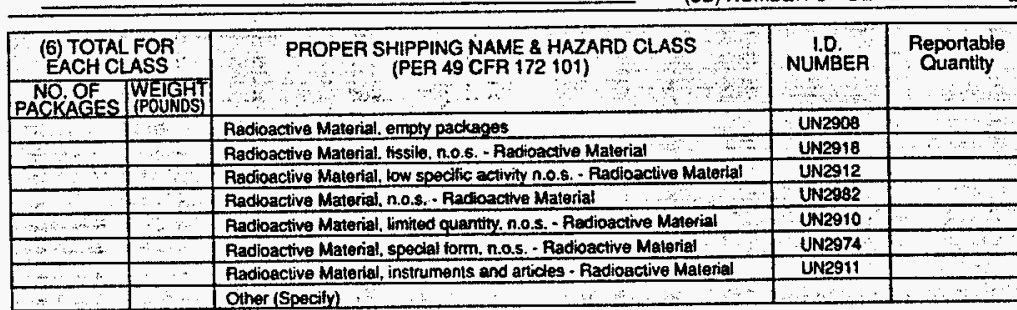

(12) WASTE DESCRIPTION (13) PHYSICAL

(16B) ( ) Yes ( ) No This waste(s) must be disposed in South Carolina Department of Health and

(17) ( ) Yes ( I NO THIS VEHICLE IS CONSIGNED EXCLUSIVE USE. LOADING AND UNLOADING MUST BE ACCOMPLISHED BY CONSIGNOR OR CONSIGNEE OR HIS DESIGNATED AGENT.

(18) IMPORTANT: "This is to certify that the above named materials are properly classified, described, packaged, marked, and labeled, and are in
the Department of Transportation.

Signature

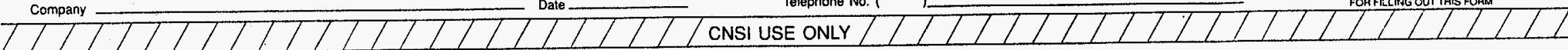

SHIPMENT I.D. NUMBER - PAGE

OF
(5)

TELEPHONE ADDRESS

TELEPHONE SHIPPING DATE

CASK IDENTIFICATION NO

SHIPMENT NO. LINEA SERIAL NO. DRIVER SIGNATURE

\begin{tabular}{|c|c|c|c|c|c|c|c|c|c|c|}
\hline \multicolumn{3}{|l|}{ (7) } & \multicolumn{5}{|c|}{ SHIPMENT TOTALS } & \multicolumn{3}{|c|}{ TOTAL SNM } \\
\hline \multirow{4}{*}{$\begin{array}{c}\text { Disposal } \\
\text { Volume } \\
\left(\text { (t. }{ }^{3}\right)\end{array}$} & \multirow{4}{*}{$\begin{array}{c}\text { Total } \\
\text { No. of } \\
\text { Packages }\end{array}$} & \multirow{2}{*}{\multicolumn{5}{|c|}{$\begin{array}{l}\text { ACTIVITY } \\
\text { Mallicuries }\end{array}$}} & \multirow{3}{*}{$\begin{array}{c}\text { Source } \\
\text { (Pounds) }\end{array}$} & Isotope & Grams & Tho. Packapes \\
\hline & & & & & & & & $\mathrm{U}-233$ & & \\
\hline & & Isofiopes & Tritium & C-14 & TC.99 & 1.129 & & U.235 & & \\
\hline & & & & & & & & Total & & \\
\hline
\end{tabular}

MiNIMUM WASTE (14) NAME AND \% OF
CHELATING AGENT

"Centification is hereby made to the South Carolina Department of Health and Environmental Control that this shipment of low-level radioactive waste has been inspected in accordance with the requirements of South Carolina Radioactive Material License No. 097 as Criteria within 48 hours prior to shipnent and lurther certification is made that ine inspection revealed no items of non-comoliance with all applicable laws, rules and regulations." Signature

Title and Organization

Form No. CNS-20

Telephone No. 1

$\{1.90)$
SEE INSTAUCTIONS ON REVERSE SIDE

$\square$ This material meets all license requirements.

This material was disposed of in accordance with license.

$\square$ Discrepancy.

$\begin{array}{ll}\text { Crane } \square & \text { Forklitt } \square \\ \text { Shielded } \square & \text { Personnel }\end{array}$

Shielded $\square \quad \begin{aligned} & \text { Personnel } \\ & \text { Barrier }\end{aligned}$

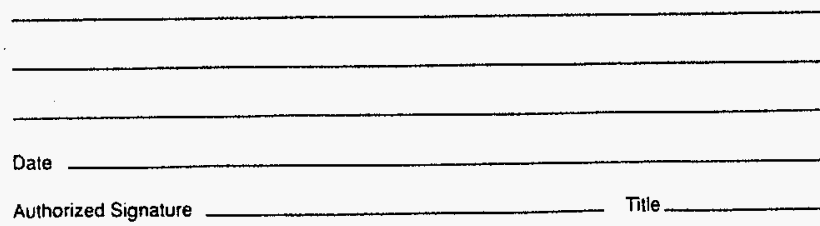

Overpack S $N$

Overpack Lid $S / N$

Other

Arrival Date

Arrival Survey No.

Date/Time Buried

H.P initial

Trench No. Location Code

Waste Class Code

Trench No. L Location Cod

Waste Class Code

Personnel Exposure

Figure 4-1. Sample radioactive shipment manifest form. 


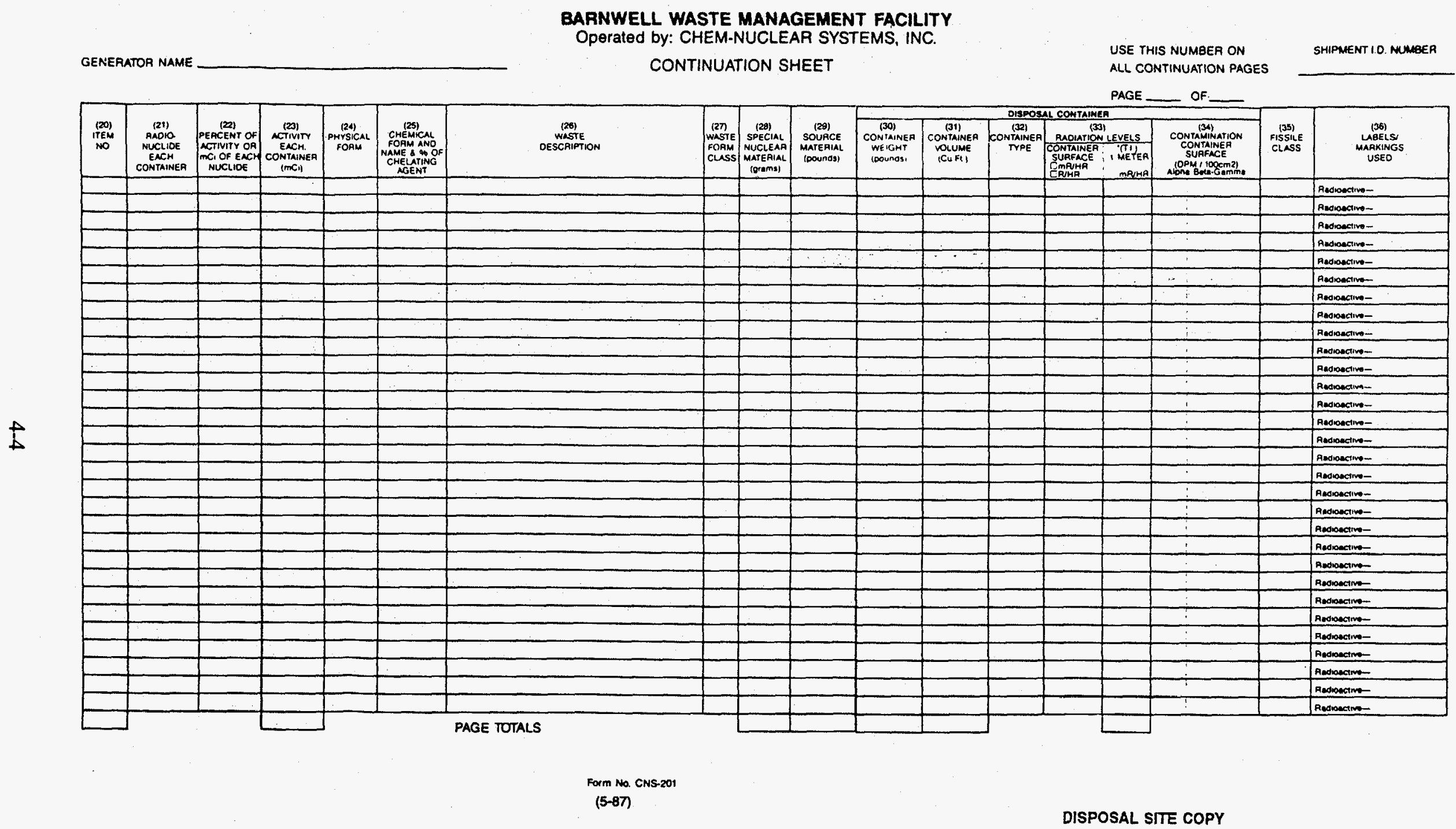

Figure 4-1. (continued). 


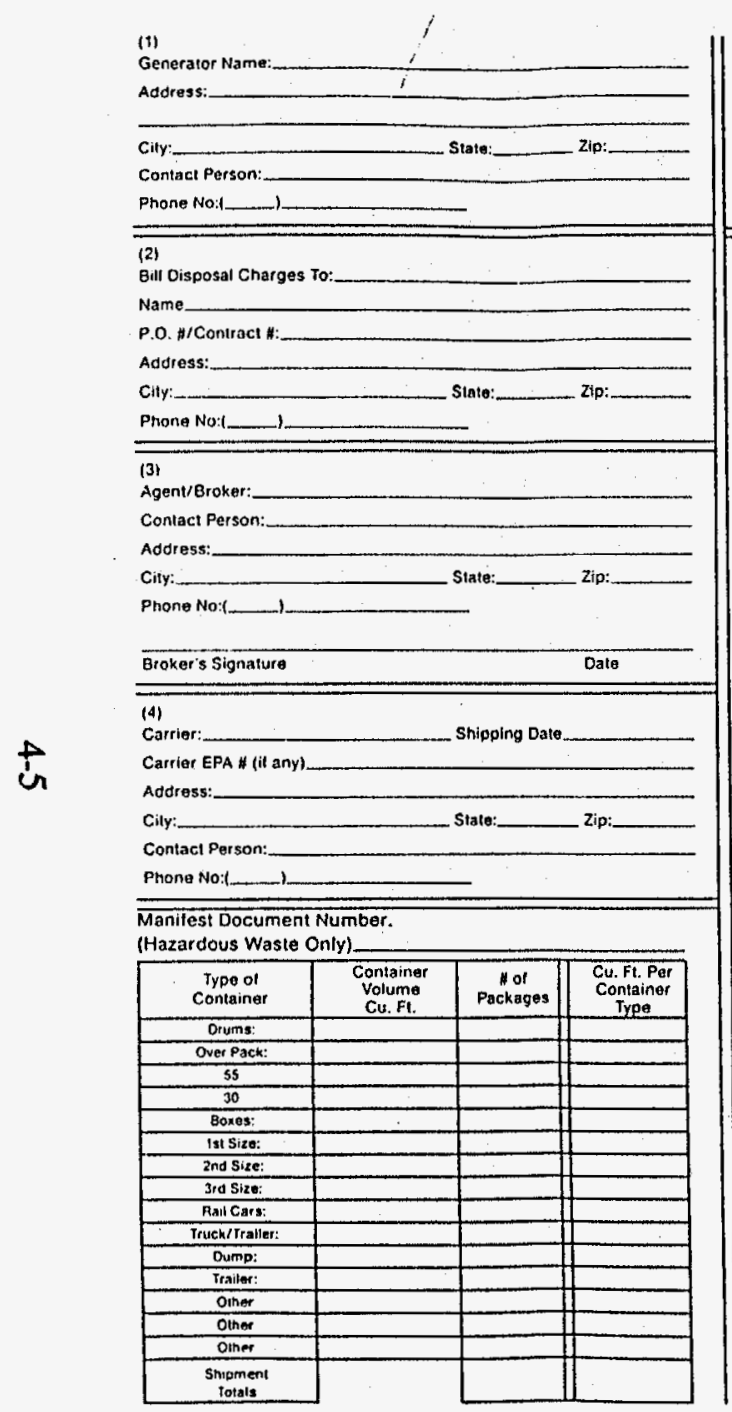

\section{RADIOACTIVE WASTE SHIPMENT \& DISPOSAL RECORD \\ ENVIROCARE OF UTAH, INC. 46 W. Broadway, Suite 240 \\ Ph. (801) 532-1330 \\ Salt Lake City, Ulah 84101

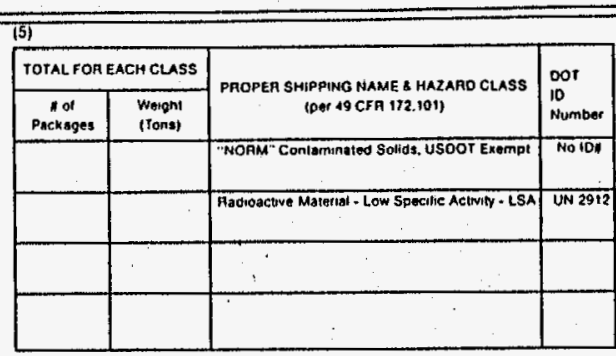

TERMS AND CONDITIONS

A. HAZARDOUS MATERIALS: Genetator represents and warrants that Waste

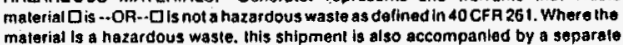
material is a hazarcous waste. His stipnentis also accompanied by a separato disposal sestrictlion notice and/or certification as required by to CFF 268.1.

TITLE: Upoh acceptance at the disposal site by Envirocare of Ulath. Inc, and all

\begin{tabular}{|c|c|c|c|c|c|c|c|c|c|}
\hline \multicolumn{10}{|c|}{ 6) } \\
\hline \multicolumn{7}{|c|}{ SHIP MENT TOTALS } & \multicolumn{3}{|c|}{ TOTAL SNM } \\
\hline \multicolumn{7}{|c|}{ Activity In Millicuries } & Isolope & Grams & $\begin{array}{l}\text { No. of } \\
\text { Cont. }\end{array}$ \\
\hline \multirow{2}{*}{$\begin{array}{l}\text { No. of } \\
\text { Contai- } \\
\text { ners } \\
\end{array}$} & \multirow{2}{*}{$\begin{array}{l}\text { Volume } \\
\text { Cu Fi. }\end{array}$} & H.-3* & C. $14^{\circ}$ & TC.99. & $1-129^{\circ}$ & & U-233 & & \\
\hline & & & & & & & U.235 & & \\
\hline & & & & & & Tolal & Pu & & \\
\hline & & & & & & & Total & & \\
\hline
\end{tabular}
Must show 0 il not present. List additional nucldes and activities in blank spaces provldod. THIS IS TO CERTIFY THAT THE MEAEIN-NAMED MATERIALS AAE PROPERLY CLASSIFIED. DESCRIBED, PACKAGED, MARKED

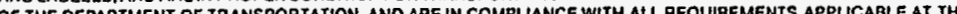
DESIGNATED DASPOSAL SITE, AND THE REOUIREMENTS OF 10 CFR PAPT 61 AND PAAT 20.311 OR EOUIVALENT STATE

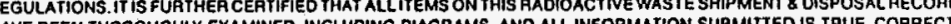

Authorked Signature or Customer Titito Date

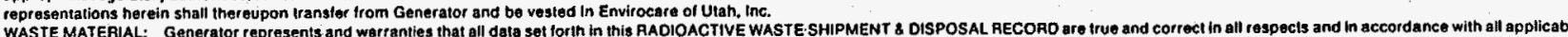

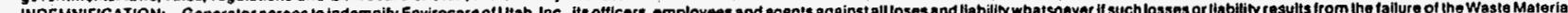

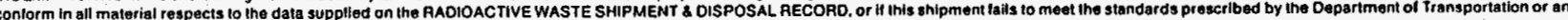
governmental agency having jurisdiction over such matters.

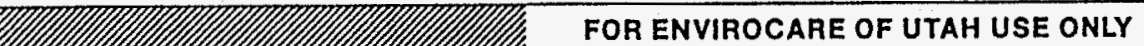

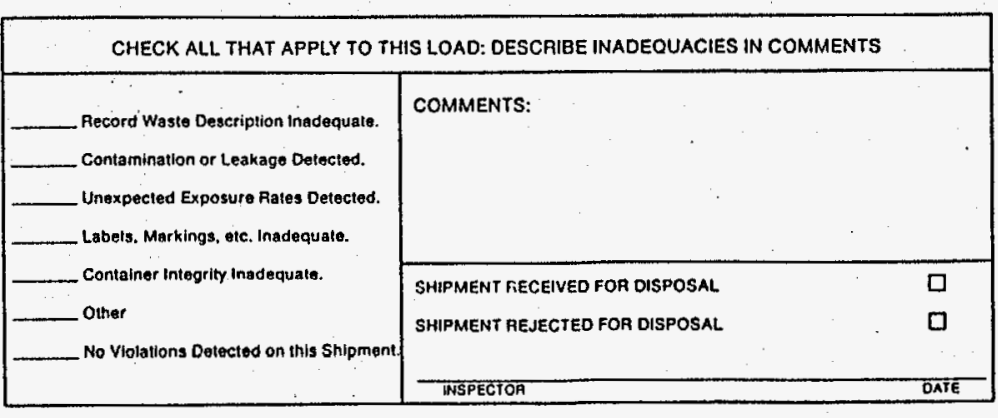

ENVIROCARE INVOICE *:

ENVIROCARE INVOICE DATE:

CNVIROCARE CUSTOMER DISTRIBUTION:

White, Yellow, Pink - Must accompany waste in transit. Green-Must be mailed to and be approved by Envirocare of Utah prior to shipment, unless a copy has been sent by lax.

Gold - Customer Copy.

\section{FORM \#E 100}

Figure 4-1. (continued). 
GENERATOR NAME:

AGENT/BROKER:

BATES:

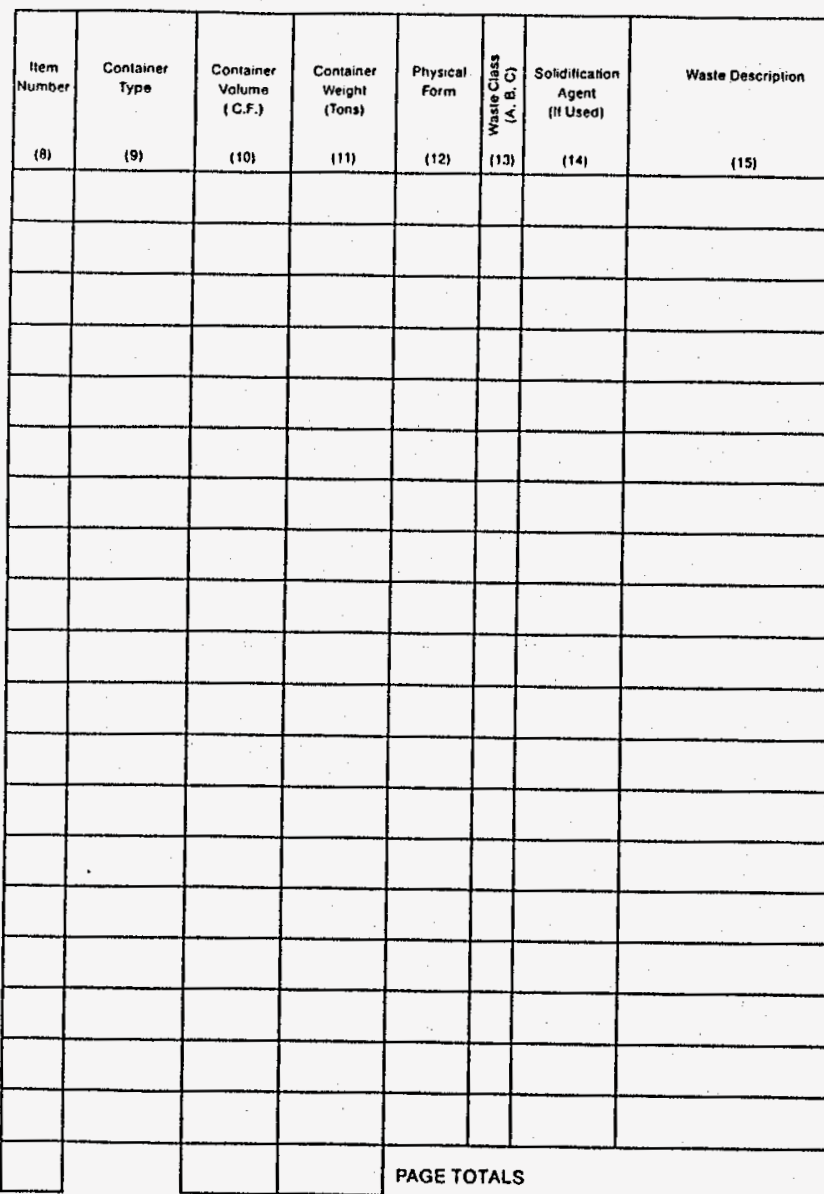

White, Yellow, Pink - Must accompany waste in transit.

Figure 4-1. (continued).

\section{ENVIROCARE OF UTAH, INC.} Continuation Sheet

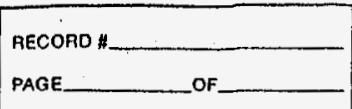

PAGE

-

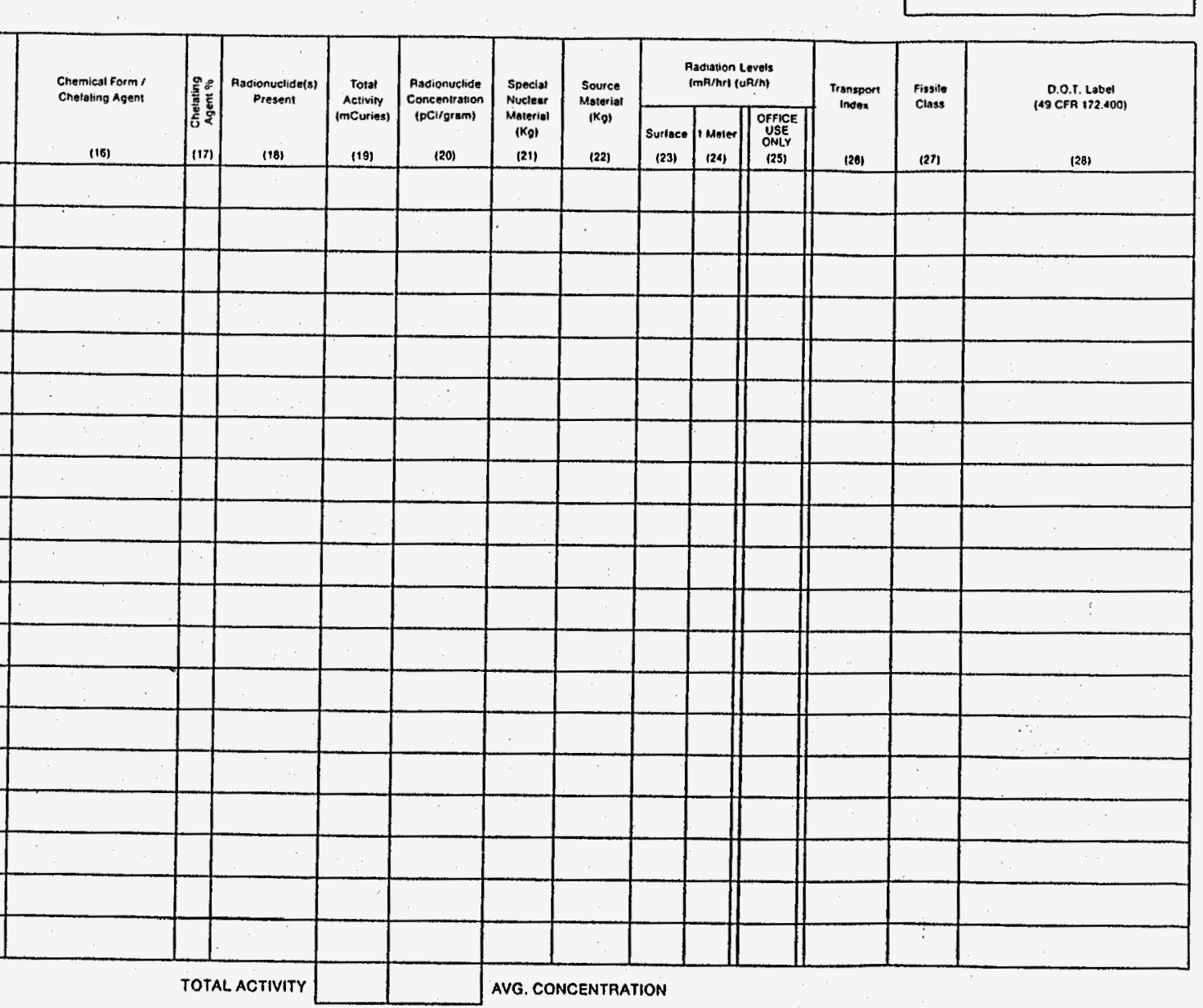

Green - Must be mailed to and approved by Envirocare of Utah prior to shipment.

Gold - Customer Copy 
- For Richland, Washington disposal, a Washington State Patrol or Washington State Utilities and Transportation Commission Vehicle Inspection Certificate or a current, visible 90-day vehicle inspection seal for intrastate vehicles is required.

3. Offloading inspections are conducted to determine that the waste meets package and waste form requirements of the license. Each package is verified to be represented on the waste manifest, and any discrepancies are identified.

4. Packages are opened. The decision to open packages varies at each facility, a random sample is taken at the Barnwell facility while $100 \%$ of the packages (for example, railcars) are sampled at Envirocare. Each facility has a specific criterion for selecting the number of containers to be opened, if any. Additional consideration is given to packages having unusual characteristics.

5. Waste handling involving package separation is conducted to group the different waste classes at the USE facilities. There are specific package storage requirements at Beatty and Richland that limit the number of days that waste can be stored above ground.

6. Specific package testing is conducted. The operational procedures define the methods used to conduct intrusive tests. Some examples of intrusive tests are:

- Waste form verification by core drilling into package contents

- $\quad$ Receipt inspection of polyethylene HIC engineered systems (opening of containers).

Table 4-1 summarizes the WAC as discussed in Section 2 and shows how the acceptance procedures at each facility provide (or fail to provide) reasonable assurance that these WAC are met. Data for the table and the accompanying discussion were derived from four sources. These sources are:

- Beatty, Nevada, Low-Level Radioactive Waste Disposal Facility Standards Manual, published by U.S. Ecology, Inc., August 1, 1989

- Richland, Washington, Facility Standards Manual, published by U.S. Ecology, Inc., May, 1992

- Chem-Nuclear Systems, Inc., Barnwell Waste Management Facility Site Disposal Criteria (S20-AD-010) Revision 7, published by Chem Nuclear Systems, Inc

- Envirocare of Utah, Inc., Waste Characterization Plan, published by Envirocare October, 1991.

All four disposal facilities rely heavily on the generator for incoming shipment verification. The disposal facility operators verify $100 \%$ of the shipment manifests, certifications, and bills of lading. In addition, the Beatty and Richland facilities require advance notification of intent to ship Class $B$ and $C$ waste. The Barnwell facility requires advance notice of all waste intended for 

Table 4-1. Disposal facility waste acceptance practices.

\begin{tabular}{|c|c|}
\hline - Sito & $\begin{array}{l}\text { Check manifest for shipper } \\
\text { certificarion and classification } \\
\text { against shipment }\end{array}$ \\
\hline $\begin{array}{l}\text { Richland, Washingeon } \\
\text { (USE) }\end{array}$ & $\begin{array}{l}\text { Yes, } 100 \% \text {. } \\
\text { USE relies heavily on waste } \\
\text { certification by generators. } \\
\text { Curent Low-Level Radioactive } \\
\text { Waste Shipment Certification } \\
\text { Form RHE-31. } \\
\text { DOENRC } 741 \text { form. } \\
\text { Chus B and C waste accepted with } \\
\text { prior nocification oniy. Washington } \\
\text { State RATM vehicle inspection }\end{array}$ \\
\hline $\begin{array}{l}\text { Beatry. Vevada } \\
\text { (USE, no longer in } \\
\text { operation) }\end{array}$ & $\begin{array}{l}\text { Yes. } 100 \% \text {. } \\
\text { USE relies heavily on waste } \\
\text { certification by generators. } \\
\text { DOENRC } 741 \text { form. if applicable. } \\
\text { Class B and } C \text { waste accepted with } \\
\text { prior nocification only. Minor } \\
\text { discrepancies with the WAC may be } \\
\text { ignored }\end{array}$ \\
\hline
\end{tabular}

\begin{tabular}{cc} 
External radiation and & Container \\
\cline { 2 - 3 } & Container \\
type \\
acceptable
\end{tabular}

Incoming waste: Yes, $100 \%$

Truck: Yes

Beta/gamma $<, 200 \mathrm{dpm} / 100 \mathrm{~cm}^{2}$

Alpha $220 \mathrm{dpm} / 100 \mathrm{~cm}^{2}$

Placards, labels, blocking, and

bracing of load

Incoming waste: Yes, $100 \%$

Truck: Yes

Beta/gamma $<, 200 \mathrm{dpm} / 100 \mathrm{~cm}^{2}$

Alpha $<20 \mathrm{dpm} / 100 \mathrm{~cm}^{2}$

Placards, labels, blocking, and

bracing of load
Yes, $20 \%$.

This is done on all shipments. In addition, $15 \%$ are set aside for a complete NDE.

Yes, 20\%

Yes, $100 \%$.

These items are preapproved since the manifest is received at the disposal site prior to shipment of the waste by the generator.
Barnwell, South Caroline Yes. 100\%.

(Chem-Nuclear)

Clive, Utah (Envirocare) Yes. 100\%.

Includes pre-characterization by generator.

Nosice to Transpor Form EC-1800.

Semple results due within 60 days prior to receipe of waste.
Incoming waste: Yes, $100 \%$

Truck: Yes

Alpha $<20 \mathrm{dpm} / 100 \mathrm{~cm}^{2}$

Beta/gamma $<2,200 \mathrm{dpm} / 100 \mathrm{~cm}^{2}$

Placards, labels, blocking, and bracing of load

Incoming waste: Yes, $100 \%$

Truck and railcar: Yes

Beta/gamma $<1,000 \mathrm{dpm} / 100 \mathrm{~cm}^{2}$ are visually inspected.
Yes, $100 \%$.

Drums, railcars, B25 boxes

All faulty or inaccurate descriptions and nonconformances are reported to DHEC and the customer. 



\begin{tabular}{|c|c|c|c|c|c|c|c|}
\hline tainer & & & & & Container content & & \\
\hline $\begin{array}{l}\text { pntainer } \\
\text { type } \\
\text { ceptable }\end{array}$ & Integrity & Configuration & Void spaces & Stability/contents & $\begin{array}{l}\text { Special container } \\
\text { required/permitted }\end{array}$ & $\begin{array}{l}\text { Structural } \\
\text { stability }\end{array}$ & Liquid content \\
\hline
\end{tabular}

\begin{tabular}{|c|c|c|c|c|c|}
\hline s. $20 \%$ & Yes, 20\% & Yes, 20\% & $\begin{array}{l}\text { Rubber mallet used } \\
\text { to examine } \\
\text { container for void } \\
\text { spaces }\end{array}$ & $\begin{array}{l}\text { Rubber mallet used } \\
\text { to indicate } \\
\text { incomplete } \\
\text { solidification }\end{array}$ & $\begin{array}{l}\text { Casks and other } \\
\text { special containers } \\
\text { will be inspected } \\
100 \% \text { and } \\
\text { documented }\end{array}$ \\
\hline
\end{tabular}

Visual inspection or reliance on manifest
Physical inspection and examination of suspect or nonconforming waste packages s, $100 \%$ Yes, $100 \% \quad$ Yes, $100 \%$

s, $100 \%$ Yes, $100 \%$ Yes, $100 \%$

s, 100\% Yes, 100\% Yes, 100\%
Tire club used to check for void spaces in drum

Periodic inspection using a wooden mallet. Rely on manifest.
Waste segregated for disposal by Class $A$, $B$, and $C$

Yes, casks must be inspected and documented $100 \%$

\section{Each waste form is} assigned a classification code for tracking by computer

Visual inspection, waste is decontainerized for disposal.
$100 \%$ inspections of all casks in maintenance building
Waste container is removed at the disposal site. The material is compacted to meet specific requirements.

\section{Not applicable}

Rely on manifest
Periodic inspection, rely on manifest

No free liquid (>1\%) inspection of HICs is permitted by USE. HICs may be checked for free liquids. All packages exhibiting universal characteristics (e.g., sloshing sounds) are checked.

Containers other than HCs may have $0.5 \%$ free liquid.

Dry waste limit is zero HIC is dewatered waste. There is a $1.0 \%$ limit on dewatered waste. Solidified waste in a steel container has a $0.5 \%$ limit.

\author{
Waste is placed Visual inspection when \\ into facility cells \\ withour \\ containers \\ content limited to less than \\ $3.0 \%$. Paint filter liquids \\ test is also conducted on \\ waste form sample.
}





\begin{tabular}{|c|c|c|c|c|c|}
\hline \multicolumn{3}{|c|}{ Chemical analysis } & \multirow[b]{2}{*}{ Descructive examinations QA } & \multirow[b]{2}{*}{$\begin{array}{l}\text { Shipper/generator } \\
\text { audits/appraisals inspections }\end{array}$} & \multirow[b]{2}{*}{$\begin{array}{l}\text { Action for } \\
\text { noncorforming } \\
\text { items/shipment }\end{array}$} \\
\hline Corrosivity & Chelacing agenes & Oils/petroleum & & & \\
\hline $\begin{array}{l}\text { Waste must be } \\
\text { neuralized or } \\
\text { treated to remove } \\
\text { the hazard. } \\
\text { Rely on manifest. }\end{array}$ & $\begin{array}{l}\text { Waste containing } \\
>0.1 \% \text { chelates is } \\
\text { segregated. This } \\
\text { waste must be } \\
\text { stabilized. }\end{array}$ & Rely on manifest & $\begin{array}{l}1 \text { out of } 15 \text { shipments or } \\
1 \text { shipment per week is subject } \\
\text { to inspection with all packages } \\
\text { individually NDE. One package } \\
\text { in shipment will be opened. } \\
\text { HICs shall not be op:ned. Waste } \\
\text { packages reading > } 100 \text { Rhr will } \\
\text { not be opened. Punctured or } \\
\text { opened packages will be } \\
\text { confined to the inspection } \\
\text { facility. Inspection of SNM } \\
\text { packages requires prior approval } \\
\text { of NRC. Shipments for random } \\
\text { inspection are selected using } \\
\text { random number sequences. } \\
\text { Avoid opening drums with } \\
\text { compared waste due to hazard. } \\
\text { Containers }>10 \text { Rhr must be } \\
\text { stuelded. }\end{array}$ & $\begin{array}{l}\text { Stote inspector receives } \\
\text { copies of all shipping } \\
\text { documents, including the } \\
\text { manifese The State of } \\
\text { Washington Department of } \\
\text { Health has initiated a } \\
\text { generator inspection } \\
\text { program. Its focus is on } \\
\text { WAC-173-303 compliance. }\end{array}$ & $\begin{array}{l}\text { Any violations of } \\
\text { hazardous waste } \\
\text { regulations will result in } \\
\text { sequestration of entire } \\
\text { shipment. Any } \\
\text { characteristically } \\
\text { significant deviation } \\
\text { shall be reported to the } \\
\text { licensing authority. } \\
\text { Repackaging of wasce } \\
\text { may be required to meet } \\
\text { facility disposal WAC } \\
\text { for otherwise } \\
\text { conforming packages. If } \\
\text { waste cannot be brought } \\
\text { into compliance, the } \\
\text { generator shall } \\
\text { remanifest the material } \\
\text { and take possession of it }\end{array}$ \\
\hline Rely on manifest & $\begin{array}{l}\text { No chelating agents } \\
>1 \% \text { by weight }\end{array}$ & Rely on manifest & $\begin{array}{l}\text { Will ream outer shipping } \\
\text { containers. Will inspect } \\
\text { packages for tree liquid } \\
\text { requirements of license. No } \\
\text { package will be opened without } \\
\text { facility manager authorization. } \\
\text { Packages suspected of containing } \\
\text { void spaces are opened. No } \\
\text { drums opened if dose rates read } \\
>100 \text { mR/hr. Random shipment. } \\
\text { Inspections taking into sceount } \\
\text { ALARA/risk considerations. }\end{array}$ & $\begin{array}{l}\text { Concurrent state inspection } \\
\text { at the discretion of inspector. } \\
\text { Problem generators receive } \\
\text { more adention than the } \\
\text { average shipment. }\end{array}$ & $\begin{array}{l}\text { Repairs and repackages. } \\
\text { dating containers, or } \\
\text { contuiners damaged in } \\
\text { transport will remanifest } \\
\text { nonconforming packages } \\
\text { arter inspection or repair } \\
\text { for ream to the shippers. } \\
\text { Packages with liquid: } \\
\text { seal holes and dispose if } \\
\text { less than } 0.5 \% \mathrm{~kg} \\
\text { volume. }\end{array}$ \\
\hline Rely on manifest. & $\begin{array}{l}\text { Percent is noted on } \\
\text { form. } 8 \% \text { is limit for } \\
\text { burial. }\end{array}$ & Rely on manifest & $\begin{array}{l}\text { Performed randomly on packages } \\
\text { from all generators. Includes } \\
\text { opening packages and puncuring } \\
\text { drums to ensure thet waste form } \\
\text { and contents conform to the } \\
\text { manifest. All shipments for } \\
\text { inspection have a radiation work } \\
\text { procedure attached to them. Also } \\
\text { inspects HICs. }\end{array}$ & $\begin{array}{l}\text { Department of Health and } \\
\text { Environmental Control } \\
\text { checks all shipments for } \\
\text { evaluation levels and the } \\
\text { tuck for highway safety. }\end{array}$ & $\begin{array}{l}\text { Shipments that cannot be } \\
\text { rendered acceptabie for } \\
\text { disposal could be } \\
\text { rewmed to the waste } \\
\text { generator. }\end{array}$ \\
\hline $\begin{array}{l}\text { Pre-characterization } \\
\text { omple analysis and } \\
\text { ow activity waste } \\
\text { profile, record } \\
\text { ertificate, chemical } \\
\text { creening is } \\
\text { performed on } 100 \% \\
\text { f containers. }\end{array}$ & $\begin{array}{l}\text { Pre-characterization } \\
\text { sample analysis and } \\
\text { low activity waste } \\
\text { profile, record } \\
\text { certificate, chemical } \\
\text { sereening is } \\
\text { performed on } 100 \% \\
\text { of comainers. }\end{array}$ & $\begin{array}{l}\text { Pre-characterization } \\
\text { sample analysis and } \\
\text { low activity waste } \\
\text { profile, record } \\
\text { certificate, chemical } \\
\text { screening is } \\
\text { performed on } 100 \% \\
\text { of containers. }\end{array}$ & $\begin{array}{l}\text { One sample per first } 10 \\
\text { shipments, one per first } 100 \mathrm{yd}^{3} \\
\text { up } 101,000 \text { yd thereafter one } \\
\text { sample per } 500 \text { yd }{ }^{3} \text {. Six } \\
\text { composites per railcar, and size } \\
\text { ocher specific composites are } \\
\text { identified per concainer. }\end{array}$ & $\begin{array}{l}\text { Third party analysis of } \\
\text { radionuclides are obtained. } \\
\text { Pre-characterization of } \\
\text { waste form and } \\
\text { classification. }\end{array}$ & $\begin{array}{l}\text { Rejection of shipment } \\
\text { can occur if the } \\
\text { pre-characterization } \\
\text { sample results are not } \\
\text { acceptable. }\end{array}$ \\
\hline
\end{tabular}



Table 4-1. (continued).

\begin{tabular}{|c|c|c|c|c|c|c|c|c|}
\hline \multirow[b]{2}{*}{ Sire } & \multicolumn{4}{|c|}{ Health and safety provection } & \multicolumn{3}{|c|}{ Radionuclick content } & \\
\hline & $\begin{array}{l}\text { Explosivef } \\
\text { reactivel } \\
\text { pyrophoric }\end{array}$ & Toxic/biohazard & $\begin{array}{l}\text { Gaseous } \\
1.5 \text { ATM }\end{array}$ & Mixed waste & TRU/SNM & Total activity & $\begin{array}{l}\text { Neutron } \\
\text { sources }\end{array}$ & \\
\hline $\begin{array}{l}\text { Richland, Washington } \\
\text { (CSE) }\end{array}$ & $\begin{array}{l}\text { Waste must } \\
\text { be treated to } \\
\text { remove the } \\
\text { hazard. Rely } \\
\text { on manifest }\end{array}$ & $\begin{array}{l}\text { Any inspection will } \\
\text { be limited to visual } \\
\text { assurance that } \\
\text { absorbent and } \\
\text { double packaging } \\
\text { requirements have } \\
\text { been met }\end{array}$ & $\begin{array}{l}\text { Requires } \\
\text { segregation } \\
\text { and } \\
\text { placement }\end{array}$ & $\begin{array}{l}\text { Prohibited. } \\
\text { Cerafieation to } \\
\text { state that no } \\
\text { waste regulated } \\
\text { by } \\
\text { WAC 173-303 } \\
\text { is contained in } \\
\text { shipment. }\end{array}$ & $\begin{array}{l}\text { Require segregation and } \\
\text { placement Disposal } \\
\text { permirued by special NRC } \\
\text { license TRU and Ra-226 } \\
\text { must not exceed the } \\
10 \text { nCi/g limit } \\
\text { Weight of package not to } \\
\text { be included in figuring } \\
\text { concentration. }\end{array}$ & Rely on manifest. & $\begin{array}{c}\text { Rely on } \\
\text { manifest } \\
\end{array}$ & $\begin{array}{l}\text { W: } \\
\text { ne } \\
\text { tre } \\
\text { the } \\
\text { Re }\end{array}$ \\
\hline
\end{tabular}

Beaxy, Nevada

(USE no longer in

operation)
Rely on

manifest
Rely on manifest

Accepts
gaseous
waste
Rely on

manifest

Rely on manifest
Bamwell, South Carolina (Chem-Nuclear)

$\begin{array}{lll}\text { Rely on manifest } & \text { Accepts } & \text { Prohibited. } \\ \text { gaseous } & \begin{array}{l}\text { Rely on } \\ \text { waste }\end{array} & \begin{array}{l}\text { manifest and } \\ \text { inspection. }\end{array}\end{array}$

Prohibited.

Rely on

inspection.
Clive, Utah

(Envirocare)
Rely on manifest
Waste acceptance Not procedures include accepted variable porable "sniffers," and other chemicals sereening inscrumentation
Prohibited.

Rely on

manifesr.

Statement

required on

certification

form that no

mixed waste is

present.
Will retum outer shipping containers - will inspect packages for free liquid requirements of license. No package will be opened without faciliog manager authorization. Packages suspected of concaining free liquid are holed. Packages suspected of containing void space are opened No drums opened if dose rave $100 \mathrm{mR} / \mathrm{hr}$. Ranciom shipment inspections ALARA/risk considerations.

SNM may be disposed under separate NRC license
Accepted in accondance with RCRA Part B permit
License amendment policy. U-235, $350 \mathrm{~g}$ maximum.
Dose rates at waste surface $>10 \mathrm{R} / \mathrm{hr}$ require segregation and placement.

Waste class to be verified by calculation using manifest quantities.

Dose rates at waste surface > $10 \mathrm{R} / \mathrm{hr}$ require segregation and placement. Waste class to be verified by calculacion using manifest quantities.

Rely on manifest

Rely on manifest

Maximum concentration limits for other radionuclides
Rely on manifest
Preat sampl. low ac profile certiric screen perfor of cons 

disposal there, regardless of class, with concurrent notification to the South Carolina DHEC. The Envirocare facility requires preshipment sample analysis and notification. Each facility treats manifest discrepancies differently depending upon the magnitude of the error or omission. Figure 4-2 is a sample of a manifest correction form used by USE.

All presently operating facilities surveyed incoming shipments for external radiation levels on the loaded truck and the individual packages as they were unloaded. Both vehicle and packages were smeared to ensure that beta/gamma and alpha smearable contamination levels were within allowable DOT limits. All presently operating facilities smeared $100 \%$ of the incoming packages. Operators have found that finding discrepancies on incoming shipments lead to more intense scrutiny of the generator, this often produced additional findings. Trucks were also inspected for placarding, and adequacy of blocks and braces on the load, as required by the DOT regulations. Figure 4-3 presents two samples of vehicle survey logs.

Although inspections vary among the presently operating facilities, containers are inspected for:

- Proper closure

- $\quad$ Package type (per DOT)

- Overall Integrity (e.g., seams, weld, etc.)

- Configuration.

Figure 4-4 is a sample of the incoming shipment acceptance procedure and checklist used at the Envirocare facility and the waste confirmation checklist used at the Richland, Washington, USE disposal facility.

The Richland facility examines $20 \%$ of incoming shipments while isolating $15 \%$ of all shipments for a complete nondestructive examination. The Beatty facility inspects incoming shipments for these characteristics without specifying a percentage. The Barnwell operator also indicated indirectly that a $100 \%$ sample was taken, and reported that all nontrivial discrepancies are reported to DHEC and the generator.

Container content verification includes:

- Inspection to ascertain if void spaces exist

- Examination of special containers such as casks

- Examination of waste form structural stability

- Examination of liquid content. 



\section{MANIFEST CORRECTION FORM}

Manifest Kumber:

Generator Humber:

Shipper/Generator

Hame:

Address:

Contact:

Telephone No.

Description of Errors:
Bates number:

Shipment Kumber:

Broker

Corrections:

Contsct Shipper: Yes __ No __ By Whon:

Corrections Authorized By:

\section{ATIACH THIS FORM TO THE MANIFEST BEING CORRECTED}

Figure 4-2. Manifest correction form. 
DATE

TIME

ALL INSPECTIONS REQUIRED BY LICENSE

ANO THE MANUAL HAYE BEEN PERFORMED.
BATES NO. SHIPPER

CARRIER

TRAILER NO:

CASK TYPE

(signature)

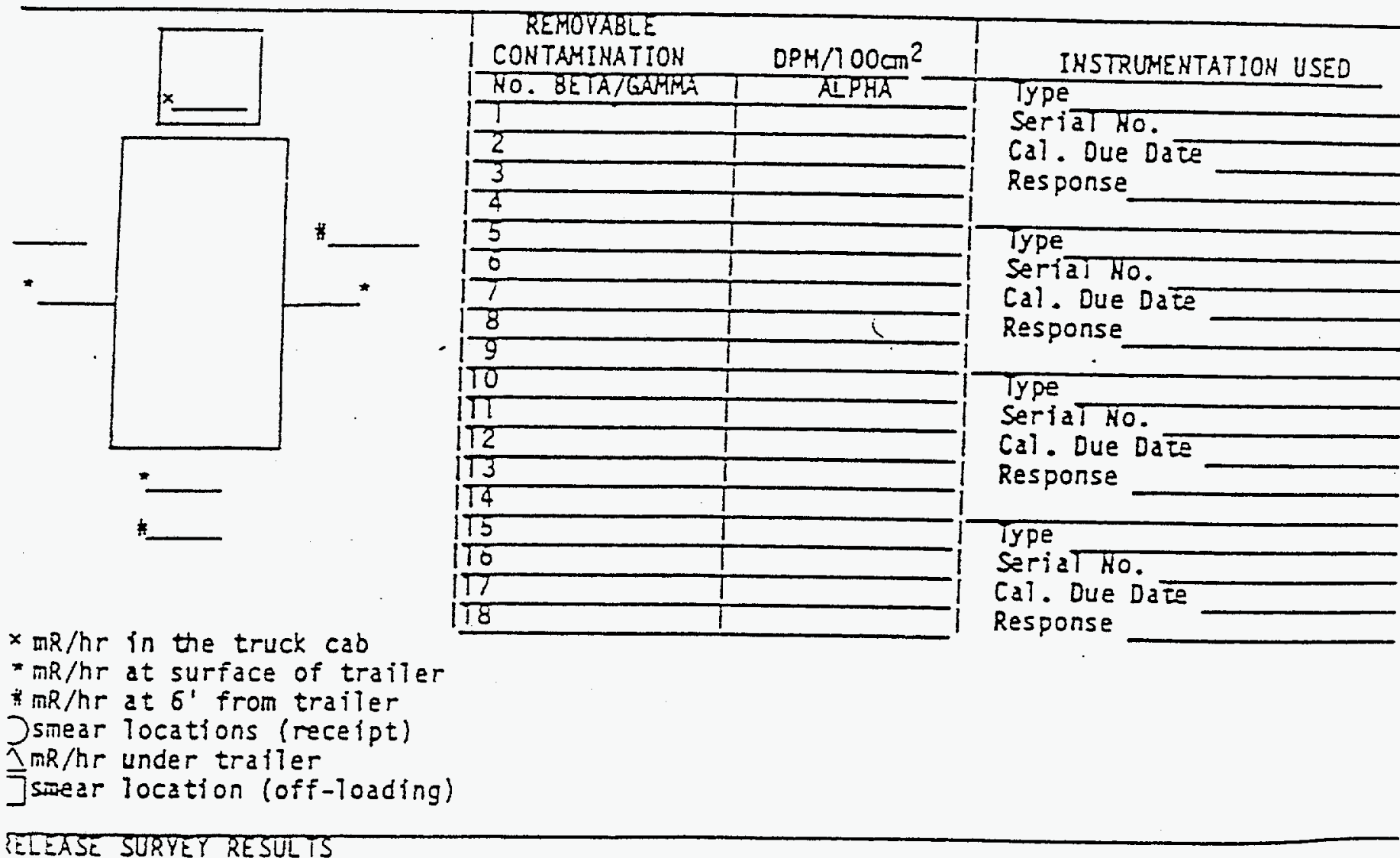

.oose surface contamination levels on traller surfaces do not exceed tie following release finits: $2200 \mathrm{OPM} / 00 \mathrm{Cm}^{2}$ beta-gama, or $220 \mathrm{DPH} / 00 \mathrm{Cm}^{2}$ aipha. Surrey results of cask internal suriaces DPM/100GL alpna Toose surface contaminetion.

THE DATE RELEASED BY REYIEXED EY

Figure 4-3. Vehicle survey log. 
CHEM-NUCLEAR SYSTEMS, INC.

ARRIVAL/RELEASE FORM

RECETIED FROM

IRAISPORT COMPANY:

IRACTOR: HO:

TRAILCA NO

CASK 10:

DATE:

NME:

II.P. ARRIVAL SUAVET

\begin{tabular}{|c|c|c|c|c|c|c|c|}
\hline \multirow{3}{*}{ MSIMUN"WT } & \multirow{3}{*}{ IEMIAI MO. } & & & & & ...... & 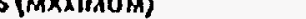 \\
\hline & & \multirow[t]{2}{*}{ Locarion } & \multicolumn{2}{|c|}{ HRINHHX } & \multicolumn{2}{|c|}{ Wmilit Dor(pum } & \multirow[t]{2}{*}{ FEMARES } \\
\hline & & & $K_{x y}$ & Avy. & YES & MO & \\
\hline & & Cos & & & & & \\
\hline & & Stritber $\operatorname{Con} 1 \times 1$ & & & & & \\
\hline & & Tu rion L metion & & & & & \\
\hline
\end{tabular}

MAXILUUM SMEARADLE COMTAHINATION

\begin{tabular}{|c|c|c|c|c|c|c|c|c|}
\hline MSIRUMCHI & sckill No. & OCCATOH & QDPM & $8 \mathrm{sm}^{1}$ & PYDF & Docen & พั7นแM & afliutrs \\
\hline & & & $M_{10 .}$ & Avr & Mas. & $\Delta x$ & $\overline{Y E S}$ & $\$$ \\
\hline & & Gltwior & & & & & & \\
\hline & & Inierions & & & & & & \\
\hline & & Othor & & & & & & \\
\hline
\end{tabular}

Lejitd DYes D D.

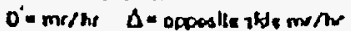

$x=5$ inasis

II. P. Technician
AS

IAERICH
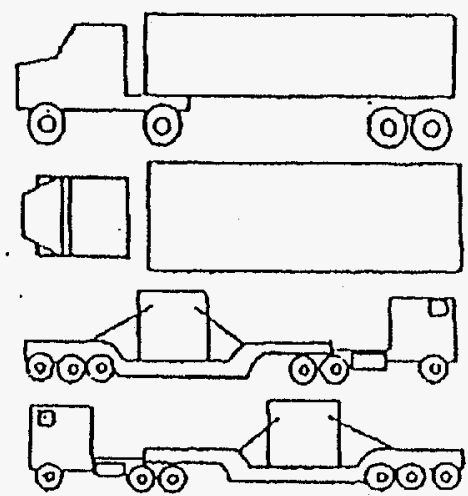

\begin{tabular}{|c|c|c|c|c|}
\hline \multicolumn{4}{|c|}{ DOSE RATES } & \multirow{5}{*}{ H. P. RE } \\
\hline 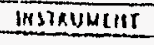 & $\operatorname{sintalmo.}$ & TOCATIOH & Mn/Iin & \\
\hline & & \multicolumn{2}{|l|}{ Intobr } & \\
\hline & & & \\
\hline & & & & \\
\hline & \multicolumn{3}{|c|}{ MA } & \\
\hline \multirow[t]{3}{*}{ IIIsrRUKENT } & SIRLALOA. & \multirow{2}{*}{\multicolumn{2}{|c|}{ 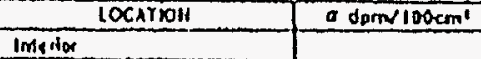 }} & SYdpm/100<m \\
\hline & & & & \\
\hline & & \multicolumn{2}{|l|}{ Foterion } & \\
\hline & \multirow{2}{*}{\multicolumn{3}{|c|}{ 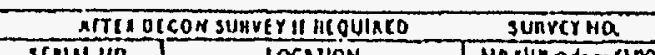 }} & \\
\hline MSSIRUACHI & & & & py $\frac{1}{n^{2} m / 100 \mathrm{cmt}}$ \\
\hline & & & & \\
\hline
\end{tabular}

Occon Required Delora felease Melkased lor Sole usa

Aelesse for Uncestricled uise

RSA Requulred ars tro

o

0

0
nST Delivered lo chist Transportallon nSR Deliverod 10 Truck Dilver

Labcls Hcuurred and apolies

Placards Required and appliad

\section{RELEASE SURVEY}

DOSE RATES
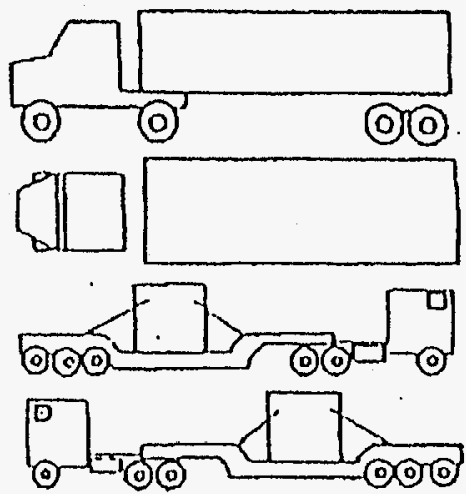

Total Dose fOlllosdiny Craws

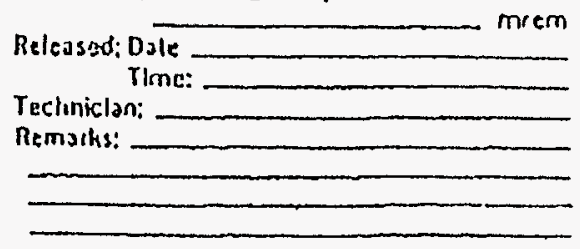

Inspeclion; Yes $\mathrm{ONOO}$

Resulls:

11. P. Thelinicion

H. P. Supervisar

Figure 4-3. (continued). 
INCOMING-SHIPHENT ACCEPTANCE

PROCRDURZ AND CHECKIIST

(2)-0525)

iReo. Harch 1991;

ACCEPTED / REJECTED IPA ID *

GLHERATOR

WASTE KUYO

DATS

MANIFZST No.

ENVIROCARE TRACXING NO.

ARRIVAI CECCXIST. Circle $Y$ or $\mathrm{K}$ below for the incoming waste. Inform the site manager of any 1 tems marked " $K "$. Once the waste is accepted or rejected, circle the corresponding word above.

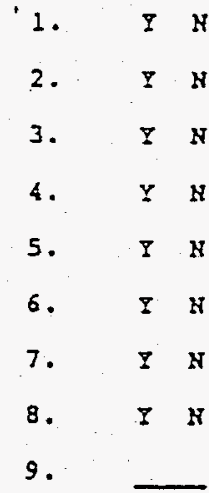

Is a completed copy of the Waste Profile Record in the site files?

Is the Waste Profile Record updated to within one year of today's date?

Is a comleted copy of the Pre-Shipment kaste Profile Record (BC-0550) in the files?

was the previous shipment accepted without special considerztion?

Is the hazardous waste manifest complete and comparable to previous manifeats?

Does the manifest accurately match the wastes on the shipment?

Do the BPA Waste Nos. mateh the numbers on the Pre-shipment waste Profile Rocord?

Do the shipping papers Indicate that the waste is not land-disposal restricted?

:zepare to safely inspect and sample the waste. Revlew the Pre-shipment Waste Profile kecord, the Waste Profile Record, and the manifest for porential herlth and safaty hazards. Wear safety eqo wear, gloves, protective clothing and footwear.

10. I $\mathrm{N}$ Are the containers in acceptable condition? (Clrele $I$ if sot applicable.)

11.

visually inspect the contents of each container. Doe 12 for this inspection result.

12. I $N$ Does the waste match the general descripelon provided on the waste Prof11e Record?

13. Sample and analyze the waste according to the Waste Analysis Plan for incoming shipments.

14. T.

was the sampling procedure followed? (It no, the Inboratory superpisor or Site renager must sign this form and the alternative sampling technique used must be daseribed below.)

15. I 1 was the on-site analgsis carsied out? (If no, the site kanager must sign this form and the reasons for the walver must be noted below.)

16.

17. IN

Record the results of andigis on the Pre-Shipment waste Profile Record (8C-0550).

Are all of the results within the established tolerances?

18. If accepted, sign the monifest and record the tracklog and penifest pumberx.l

19.

Roplace 211 lids on the contalners. Iabel each container with the Bnvirocare tracking number. Make the shiporent ready for movenent.

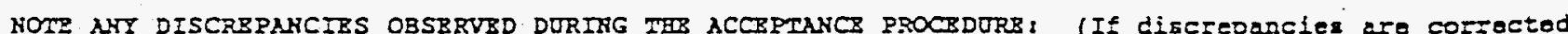
and she shipment is accepted, note the discrepascies, cite the measures taken to correct the problem, use an additlonel form if necessary and attach this form to it. Use the geverse side of this form for sore space lit necessarp.l

Inspector's Signature

Ladoratorg Supervisor's or Site hanage's Signature if applicala

Figure 4-4. Incoming shipment acceptance procedure and checklist. 
rmus ur

ainumeni 0 -

(11/2/87)

WASTE CONFIRMATION CHECKLIST

UAIC:

GENERATOR/BROKER:

BATES

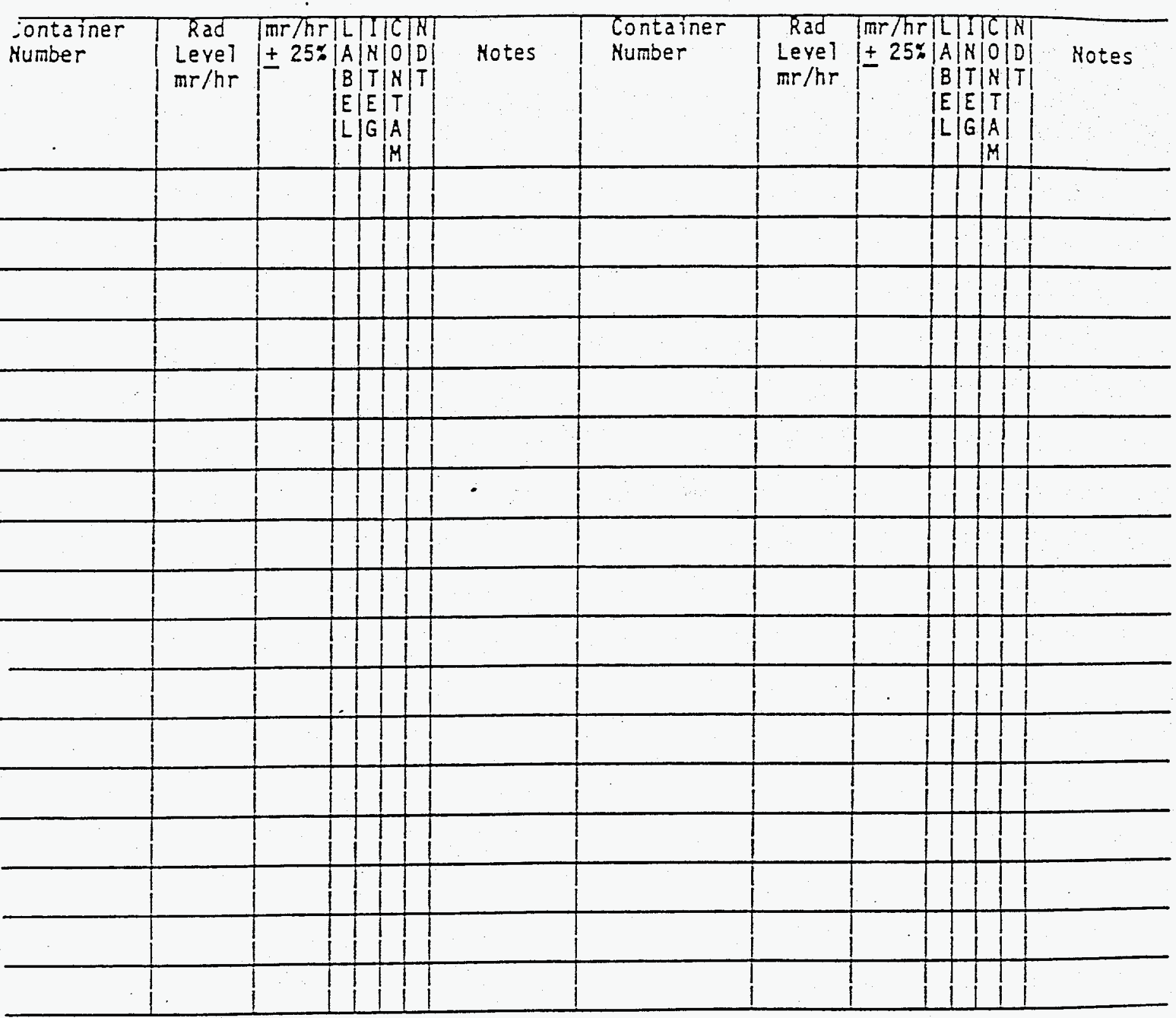

icrepancies for hotes as follows:

formed by:

FRCESO Reveiw:

Offloading RCEST

Figure 4-4. (continued). 
Manifest Number:

Generator Number:

\section{Shipper/Generator}

Name:

\section{Address:}

Contact:

Supplies and Man-Hours Expended:

\section{Radiation Exposure Information}

Starting Finishing Total

\begin{tabular}{c|c|c} 
Name $\mid$ P.D. Reading & P.D. Reading & Exposure \\
\hline 1 & 1 & 1 \\
\hline 1 & 1 & 1 \\
\hline 1 & 1 & 1 \\
\hline 1 & 1 & 1 \\
\hline 1 & 1 & 1 \\
\hline 1 & 1 & 1
\end{tabular}

Total Man Hours

for Job:

Total Man-Mrem

for Job:

Results of Confimation:

Prepared By:

Reviewed By:

Resident Inspector Review

Figure 4-4. (continued). 
PAGE 2 OF 2

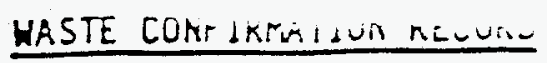

\section{BATES NLMEER}

1. PERSONNEL PERFORMING CONFIRMRTION

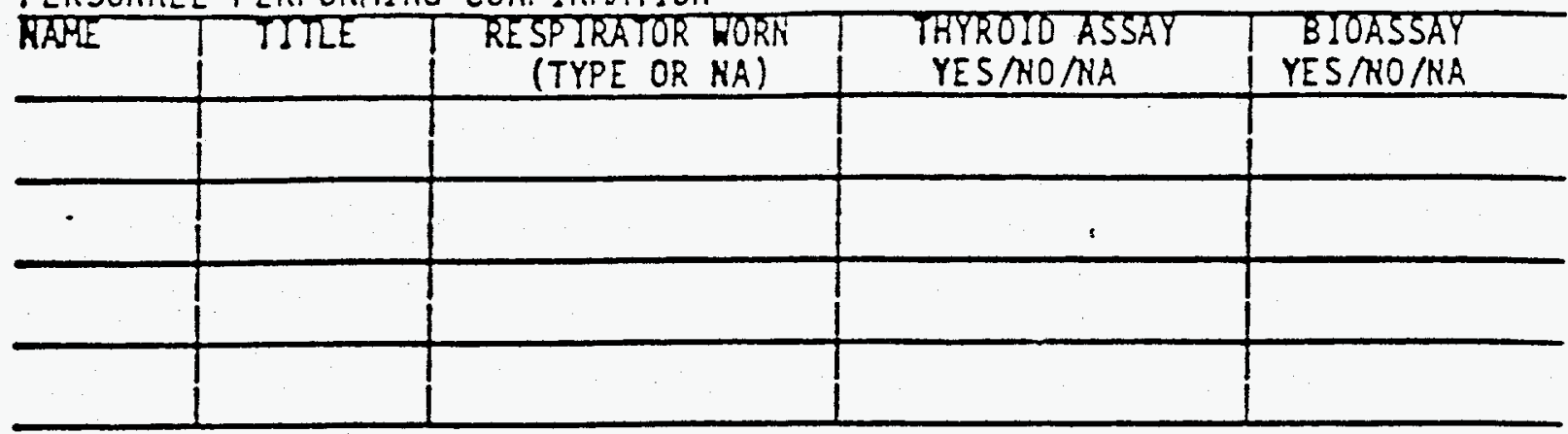

2. RESULTS OF PORTABLE AIR SAMPLES PERFORMED

\begin{tabular}{l|l|l|l|l} 
DATE TTIME & \multicolumn{2}{|c|}{ RESULTS (UCi/mI) } & ANALYZED BY \\
& Beta-gamma & lodine & Alpha & (INITIALS) \\
\hline & & & & \\
\hline & & & & \\
\hline & & & & \\
\hline & & & & \\
\hline
\end{tabular}

3. CONTAINER INSPECTION CHRONOLOGY

INSTRUMENT DATE

\begin{tabular}{l|l|l|l|l}
\hline TYPE & TYPE & TYPE & \\
\hline SERIRL RO & SERIAL RO & SERIAL RO & \\
\hline CAL DUE DRTE & CAL DUE DATE & CAL DUE DRTE & \\
\hline SOURCE CRECK & SOURCE CHECK & SOURCE CRECK & \\
\hline
\end{tabular}

SURYEYED BY:

REYIEUED BY:

Figure 4-4. (continued). 
All presently operating facilities require vehicle survey logs for casks or other HICs. Figure 4-5 shows an example of a cask inspection form. Figure 4-6 presents a sample of an HIC engineered barrier receipt checklist.

Void spaces and liquids were inspected on suspicious containers or on a percentage of waste packages at the Richland and Beatty facilities. The method involved using a rubber mallet or tire hammer to listen for differences in the sound, which may indicate either voids or liquid. If sound differences were noted, the containers were either punctured or opened for visual examination. After examination, the containers were resealed and buried if no liquids or voids were found. If liquids were found, the percentage was calculated and, if nonconforming, the generator was notified for corrective action. Figure 4-7 shows a sample of a package liquid verification checklist used at the disposal facilities. If the void spaces could not be corrected onsite, the generator was also notified. At the Barnwell facility, waste liquid limits were specified; however, periodic inspection requirements to check for voids and/or liquids were not. Upon receipt, each waste form is assigned a classification so that it can be tracked by computer. In the area of structural stability, i.e. the ability of a waste form to maintain integrity under the rigors of disposal, all four disposal facilities relied heavily on the manifest, which is appropriate, since it is difficult to assess structural integrity in a field inspection.

Radionuclide content is checked against the manifest and weight by container for $100 \%$ of the shipments at the Beatty and Richland facilities. Although not specifically stated in the Barnwell facility procedure, the health physicist performs the same task at that disposal facility. The State regulatory agencies have licensed all four disposal facilities to accept less than 350 grams U-235, 200 grams U-233, and 200 grams of $\mathrm{Pu}$ (in accordance with the sum of fractions rule) of SNM. These totals are also independently verified upon receipt of waste for burial. For all other waste, the TRU content is checked to ensure that the $100 \mathrm{nCi} / \mathrm{g}$ limit is not exceeded (at Richland, the procedure states a limit of $10 \mathrm{nCi} / \mathrm{g}$ ). The facility procedures are silent on verification of neutron sources.

The facilities do not specify that chemical analyses or radiochemical analyses can or should be performed on the waste. The facilities rely on waste stabilization to mitigate waste corrosivity. The Richland facility specifies stabilization if the waste contains more than $0.1 \%$ chelating agents. The Beatty facility specifies $1.0 \%$, and the Barnwell facility requires the percentage of chelating agents to be less than $8 \%$ by weight. This requires the generator to meet the waste form requirements. The Richland facility also specifies stabilization if the oil content of the waste exceeds $10 \%$. The Beatty and Barnwell facilities do not have this requirement.

Destructive examinations are required by procedure at all sites. ALARA considerations and the safety of operating personnel are paramount with these types of intrusive sampling activities. Richland randomly selects 1 out of 15 shipments for inspection, and notifies the State of Washington resident inspectors when they do so. They do not open HIC containers or containers with an external dose rate exceeding $100 \mathrm{mR} / \mathrm{hr}$. Penetrated packages are confined to a waste examination facility. Opening SNM waste packages requires the prior approval of the NRC. Drums with compacted waste are not opened because of the possibility of a recoil injury to personnel. The Beatty facility has similar restrictions, without a specified inspection frequency requirement. No packages were opened at that facility without prior approval by the facility manager. The Barnwell facility also has a random inspection program to ensure that all generators have an equal opportunity for inspection. The program includes puncturing waste packages and collecting samples. 
CASK IHSPECTION FOAH

Each of the below listed items nust be checked SATISFACTORY prior to the cask being released use. If an UNSATISFACTORY is checked, it aust be documented and corrected prior to release.

CASK TYPE UNIT NO.

\section{SATISFACTORY}

7. TIEDOWN DEYICES

2. LIFTING LUES ON CASK

3. BOLT CONDITIONS

4. BOLT HOLE CONOITIONS

5. LIFTING LUGS ON LID

6. LIO CONOITION

7. DOKEL CONDITION

8. INNER GASKET CONDITION

9. OUTER GASKET CONDITION

10. INTER IOR CONDITION

11. EXTERIOR CONDITION

12. DRAIN PLUG

13. HAME PLATE

14. CONTAMINATION SURYEY

15. RADIATION SURYEY

HUIE ANY DISCREPANCIES:
OXNER

\section{UNSATISFACTORY}

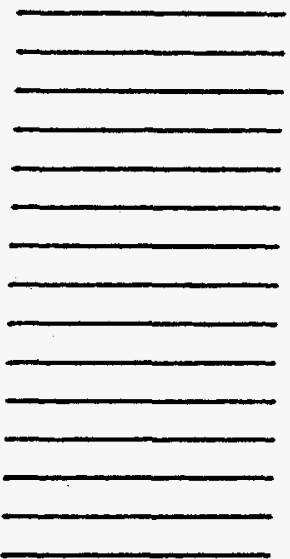

HUIE ANY DISCREPANCIES:

CORRECTIYE ACTION TAKEN:

SEAL HAS BEEN INSTALLED, YEHICLE IS PLACARDED AS REQUIRED.

COHNENTS:

Figure 4-5. Cask inspections form. 
Engineered Barrier Identification Number Date

\begin{tabular}{|l|l|l|l|l|}
\hline \multicolumn{1}{|c|}{$\begin{array}{l}\text { Yisual } \\
\text { Inspection }\end{array}$} & $\begin{array}{c}\text { Cylinder with Base } \\
\text { Sat }\end{array}$ & Unsat & Sat Cover & Unsat \\
\hline General Appearance & & & & \\
\hline Cracks & & & & \\
\hline Spalling & & & & \\
\hline Coupling Free of & & & & \\
\hline Foreign Haterial & & & N/A & \\
\hline Studs (6) & & & N/A & \\
\hline Washers (6) & & & & \\
\hline Nuts (6) & & & & \\
\hline $\begin{array}{l}\text { Independent } \\
\text { Engineers Certification }\end{array}$ & & & & \\
\hline
\end{tabular}

Remarks:

RC\&ST

FRC\&SO Review

Figure 4-6. Poly HIC engineered barrier receipt checklist. 


\section{PACKAGE LIQUID VERIFICATION CHECKLIST}

Date of Verffication

1. Generator

2. Shipment No.

Bates $\mathrm{Ho}$.

3. Contact

Telephoné No.

4. Package $\mathrm{No}(\mathrm{s})$.

5. Radionuclides, waste description, radiation levels, etc. (see attached manifest).

6. Reason for package liquid verffication

7. Hazard evaluation conclusions

8. Persons Notified of Inspection

Title

Name

Date

Time Granted Yes/No
A.
B.
C.
D.
E.

9. Results of inspection

10. Evaluation of occupation exposure to radiation (internal and external).

Figure 4-7. Package liquid verification checklist. 
A review of the disposal facility operator's procedure listings revealed no evidence of a formal procedure for conducting generator site audits. However, the Washington Department of Health Division of Radiation Protection developed the Point of Origin Inspection Program. This program involves regulators completing the Point of Origin Inspection Report. An example of this report is provided in Appendix $\mathrm{C}$. The intent of this program is to verify that generators using the USE LLW facility are complying with the requirements and intent of Washington Administrative Codes Title 246, Chapter 249, and the facility operator's license conditions. The Point of Origin Program covers the following key items:

- Management control

- Identification of responsible parties (radiation safety officer)

- Identification of type of business

- $\quad$ Training program descriptions

- Presence of management evaluations

- Operations

- $\quad$ Review of procedures

- Identification of typical waste streams

- Packaging documentation

- Waste accountability practice

- Visual inspection of waste containers

- Descriptions of any outside vendor volume reduction process used

- Preparation for shipment

- Annual volume and activity estimates

- Number of shipments

- Evidence of DOT regulations present

- Summary of the types of specification containers used

- Review of radiological instrumentation adequacy and calibration records

- Inspection of package contents

- Review of packaging procedures

- Evidence of proper packaging compliance

- Radiological survey results for outgoing shipments

- 24-hour contact number

- Summary of noncompliance/items of concern

- Identification of the regulation

- Inclusion of a brief statement of concern

- Inspector signature line.

Currently host State regulators have the authority to conduct audits similar to those of the State of Washington. The State Radiation Protection Division programs in Nevada and South Carolina do not have generator verification programs, however. The following scenarios could be postulated for regulator verification programs in cooperation with other Agreement States and the NRC: 
- Host State regulatory agencies audit generators within its State boundaries

- State agencies within the compact could cooperatively audit the generator sites within their States

- Out-of-compact State agencies could cooperatively audit generator sites and pass the fee for their audits on to the generator in addition to their surcharges

- Generators could bear the cost of the disposal facility operators conducting annual audits as warranted by the amount of waste volume disposed per year

- Each generator's State Radiation Control Division could add the verification of generator compliance to the LLW disposal facility WAC to their annual inspection checklist.

The State of Washington has recently instituted a generator inspection program focused on compliance with WAC 173-303, the State Hazardous Waste Regulations. The State's goal is to provide assurance, through periodic inspections of generators waste production, that mixed waste is not being packaged and disposed in landfills licensed only for LLW. At all four facilities, local inspectors representing the State are given duplicate copies of the manifest and may participate in the waste acceptance process. Local inspectors always participate in the waste acceptance process at the Barnwell facility.

All four facilities attempt to solve problems with nonconforming shipments, and will hold the generator financially liable for the cost of remediation. If the waste packages cannot be brought into conformance with the applicable WAC, the entire shipment is usually sequestered, remanifested, and returned to the generator. An alternative is to place a telephone call and to issue a letter to the generator requiring correction of the problem and giving them the option of visiting the disposal site or taking the waste back and fixing it at the point of generation. Repeated problems with waste received from generators invariably results in the loss of disposal privileges until that generator demonstrates that the problems that caused the nonconformance have been permanently corrected. 


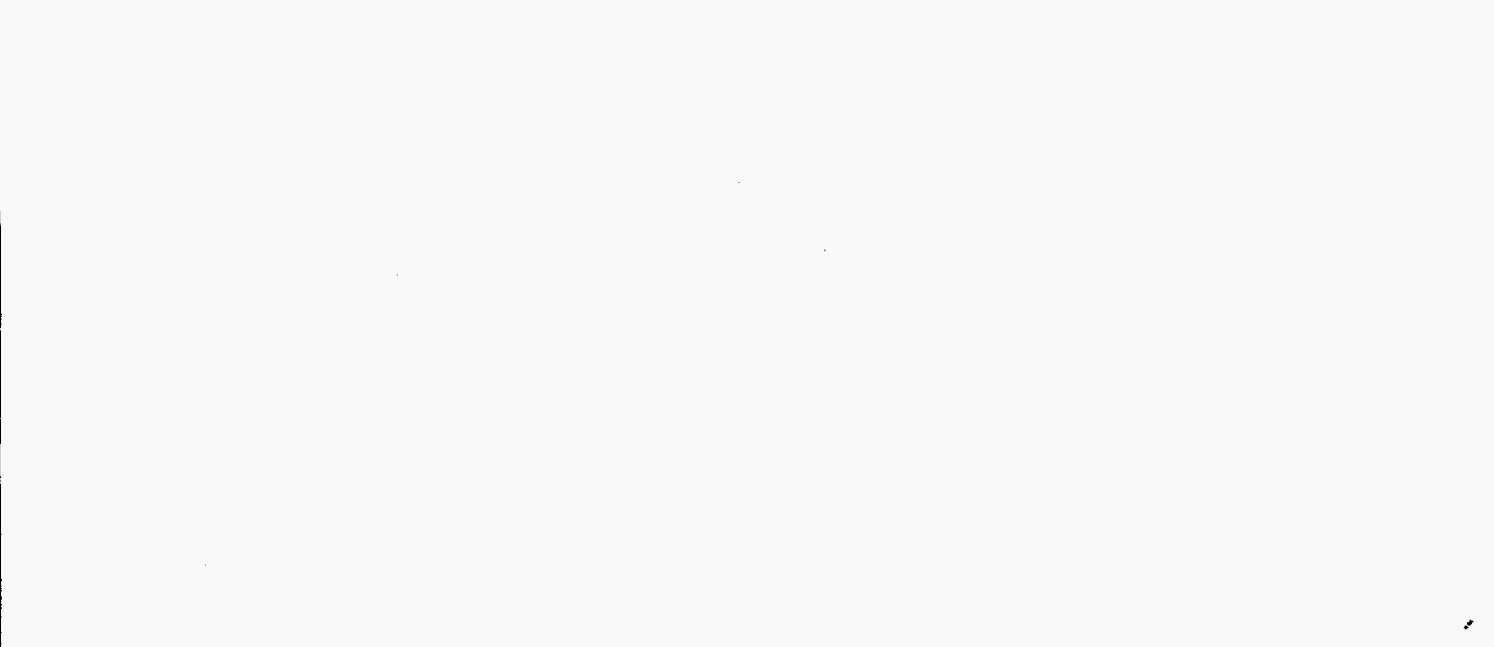




\section{INSTRUMENTS AND TECHNOLOGIES TO VERIFY COMPLIANCE WITH WASTE ACCEPTANCE CRITERIA}

There is a wide variety of radiation and waste form detection equipment used throughout the nuclear industry available for the inspection and verification of LLW. This equipment ranges from the simple hand-held instrumentation to very sophisticated spectroscopy and radiography systems. Because of some of the latest advancements in detection technologies, such as computerized controllers and data acquisition, system automation for high throughput, and highly specialized systems of detectors for specific applications, there is a substantial amount of applicable detection equipment available. However, this equipment is not generally in use for the inspection and verification of LLW within the U.S.

There are two primary considerations for the evaluation of LLW with respect to radiation detection equipment. The first is that detection equipment must be capable of surveying containerized TRU material in a manner that ensures that quantities of transuranics prescribed under 10 CFR 61 are not exceeded for disposal at a LLW facility. For gamma measurements, this requires adequate instrument sensitivity, and radionuclide quantitative and qualitative capabilities. Secondly, neutron measurements of waste containers may also be necessary for the verification of wastes that may contain significant quantities of non-TRU gamma-emitting nuclides.

Additional requirements for waste drum inspections include determining the integrity of the drum walls to identify corrosion and certifying that the contents have a liquid content of less than $0.5 \%$ by volume. Additionally, waste drums may be considered unsafe if they contain high-density objects. Through the use of techniques such as real-time radiography, $\mathrm{x}$-ray digital radiography, computed tomography, and ultrasonic detection, characterization of the actual waste form can be verified prior to the final disposal of the LLW.

Although there are a number of companies who manufacture various detection systems, the product information provided in the remainder of this section is limited to that which represents the latest state-of-the-art technologies most applicable to the inspection and verification of nuclear utility, hospital, and other institutional LLW targeted for disposal at a LLW facility. This product information has been categorized by the system type and summarized by manufacturer product descriptions. This section is limited by the availability of specific product information at the time this report was developed.

\subsection{Barrel Monitors}

Drum scanners or barrel monitors are used to perform radiological analysis on 55-gallon drums containing LLW. The results of the analysis are used to document compliance to the WAC. The LLW barrel monitors cover a broad range of technical capabilities, depending upon the component configurations. The barrel monitors presented within this subsection are comprised of radioactive detectors, such as sodium iodide ( $\mathrm{NaI}$ ) or germanium (Ge); the supporting electronics, which include a multichannel analyzer connected to a personal computer (PC); and the associated hardware to support the barrel movements. Several different systems are summarized in the following subsections. Each subsection summary includes a description of the components, and the efficiency and detection capability of each system. 


\subsubsection{MBS-550 Waste Barrel Assay System}

The MBS-550 waste barrel assay system is designed for assaying general gamma-emitting radionuclides in steel containers or transuranics in low-density materials. A shielded detection subsystem accompanies the barrel handling system on which the analysis is to be performed. This portion of the system contains the radiation detector and the shielding, which is interposed between the detector and background sources of radiation. Shielding from background radiation is necessary to optimize the ability of the system to detect and distinguish very low levels of photons emitted by small amounts of radioactive material.

The support electronics include a high-voltage source and signal conditioning electronics, such as a pre-amplifier and amplifier. These components provide the high voltage required by the detectors and provide electronic coupling and pulse shaping for the signal generated by the interaction of photons with detectors, resulting in a range of pulse heights compatible with the input specifications of the analog-to-digital convertor (ADC) of the multichannel analysis module.

The remaining system supports the pulse height analysis, spectrum analysis computation, and reporting functions. A multichannel analyzer incorporates an ADC to detect and count signal pulses corresponding to the interaction of photons with the detectors.

Several accessories are required to support full operation of the system in support of a radioactive waste program. Radioactive calibration sources are used to perform routine daily energy calibration and efficiency verification. A calibration geometry complete with radioactive sources is required to perform initial system calibration and periodic recalibration with at least annual or biannual frequency.

The MBS-550 system consists of the following components:

\section{Model}

MF400

CPHDS30-15200

TC950

TC244

TB4/TC911

PCAII-8000

286-12

HP IIP

GDR 6.1

\section{Description}

Mechanical system: motorized turntable, detector platform and graded lead shield, tungsten-lined collimator with $2 \times 7$-in. front opening, and manual (motorized) system for lifting barrel

Ge detector, 15\% efficiency, 2.0 Full Width Half Maximum (FWHM)

High-voltage detector bias power supply

Spectroscopy amplifier

NIM bin power supply with status indicator

Multi-channel analyzer with 8,192 channel $\mathrm{ADC}$ and $100 \mathrm{MHz}$ clock frequency

Computer

Laser printer

Gamma analysis software. 
The barrel to be counted is placed on the turntable. The vertical drive motor is set and turned to move the barrel past the detector. The detector, housed in lead shielding, views the barrel. The detector signal is then fed to the ADC and processed in the multichannel analyzer (all of which is a part of the PCA-II card). The analysis software in the computer converts the data to reports, which include a peak search report and activity report. These reports are printed out on the laser printer.

The model MBS-550 barrel scanner is designed to count containers ranging in size from 5- to 55-gallon drums. A motorized turntable holds the barrels and rotates at a fixed rotation of $10 \mathrm{rpm}$. The detector is mounted on a platform that moves horizontally on manual rollers to accommodate different drum diameters.

The MCA, model PCA-II 8000 , is a full featured plug-in board with 8,192 fully buffered channels operating at $100 \mathrm{MHz}$ clock frequency. The computer is an Intel $80286-12 \mathrm{MHz}$ based computer. The detector electronics include a research-grade amplifier model TC-244, highvoltage power supply model TC-950, and a nuclear instrumentation module (NIM) bin, model TB4-TC911 to house the electronics. The hyper-pure Ge detector, model CPHDS30-15200, has an efficiency of $15 \%$, a resolution of $2.0 \mathrm{FWHM}$ at $1332 \mathrm{KeV}$, and a dewar capacity of $30 \mathrm{~L}$.

The minimum requirements to operate the MBS-550 waste barrel assay system are:

Power: $220 \mathrm{Vac}, 50 \mathrm{~Hz}, 8$ amps.

Space for barrel scanner: $36 \times 60$ in.

Space for computer operation: $30 \times 60$ in.

Usage rate:

Approximately 12 to $15 \mathrm{~L} /$ week; for Ge detector systems, liquid nitrogen is required to cool the detector

Temperature:

$70^{\circ} \mathrm{F}$, plus or minus $5^{\circ} \mathrm{F}$

Floor loading capacity:

$70 \mathrm{lb} / \mathrm{ft}^{2}$

\subsection{2 $Q^{2}$ Low Level Radioactive Waste Assay System - Canberra Nuclear}

The $\mathrm{Q}^{2}$ is both a quantitative and qualitative waste assay system for analyzing 55-gallon drums. With this system, the detectors and the waste drum are totally enclosed in a 4-in.-thick low background steel shield. This can be increased to 6 in. for higher background conditions. The inside of the shield is covered by a thin stainless steel liner to allow for ease of decontamination. The drum is placed on a turntable that rotates at approximately $10 \mathrm{rpm}$ when the shield door is closed. Strain gauges mounted on the turntable structure automatically weigh the sample. The weight is then fed to a computer, which uses it to correct analysis results for matrix attenuation accounting for sample density. 
There are two detector options available, depending on the customer requirements. The first option is two large NaI detectors, each $3 \times 5 \times 16$ in., mounted in a thermal isolation package. The detectors are mounted vertically one above the other so that the detector material covers the full container height. The second option uses three Ge detectors with a $20 \%$ relative efficiency. These detectors are mounted in five-day multi-altitude cryostats.

The choice between $\mathrm{NaI}$ and $\mathrm{Ge}$ detectors are dependent on the application. Ge detectors are better suited for complex or unknown mixtures, while NaI detectors are better suited for demonstrating that certain nuclides are absent, or to quantify simple mixtures. NaI detectors are more sensitive, easier to maintain, and less expensive. Ge detectors have a wider dynamic range, better ability to detect low energy nuclides in the presence of high-energy nuclides, better temperature stability, and allow for easier confirmation of the computer results.

The standard electronics for this system are somewhat dependent on the detector type chosen, but consist of standard NIM electronics interfaced to a multichannel analyzer and controlled by an IBM or compatible $\mathrm{PC}$ system. The software for the $\mathrm{Q}^{2}$ system is derived from the Canberra ABACOS-II whole body counting software. Waste assay routines developed by Canberra have been incorporated to correct for sample density and to provide for correlation of gamma-emitters to nongamma-emitters based on waste stream type. Supervisor menus provide for calibration, review of stored spectra at a later date, editing of waste stream correlations, and QC reports.

A minimum detectable activity of $3 \mathrm{nCi}$ to $12 \mathrm{nCi}$ per drum can be achieved for nuclides of 300 to $1,500 \mathrm{keV}$ and $100 \%$ gamma abundance. This sensitivity can be achieved in one minute for the NaI system and in $\mathbf{1 0}$ minutes for the Ge system. Worst-case accuracy is reported to be $+/-$ a factor of two for point sources of radioactivity located anywhere in the sample chamber when the sample density is $1 \mathrm{~g} / \mathrm{cc}$ or less.

\subsubsection{Model 2440 Waste Assay System - Canberra Nuclear}

The model 2440 series of waste assay systems represents Canberra's current generation of systems designed to assay low-level medical, industrial, or nuclear power plant radioactive waste containers of low- to medium-density materials. The system is designed to measure containers up to 55 gallons in size. Other configurations may be custom designed to meet specific needs.

The system measures the gamma radiation emitted from waste containers using a high purity Ge detector mounted in a lead shield and collimator to control the measurement field of view. An optional transmission source can be used to measure the density of the matrix material in the drum to correct for absorption in the matrix. Measurements are made with the drum rotating to make the radial response as uniform as possible. The assay mechanism rotates the drum. The detector and collimator move vertically so that the drum is measured in several discrete segments. This optimizes the detector to sample geometry and improves the accuracy by performing matrix corrections for each segment of the drum. Other corrections can be made for count rate losses, different container sizes, etc. Results from the measured gamma data can be used to report values for nongamma-emitting nuclides through the use of user defined waste streams and correlation factors. 
The detection device in this system is a Canberra model GC3019 coaxial high purity Ge (HPGe) detector with an energy resolution of $1.9 \mathrm{keV}$ FWHM for 1,332 keV gammas and a peak efficiency of $30 \%$ relative to a $3 \times 3$-in. $\mathrm{NaI}(\mathrm{Tl})$ detector. It is mounted in a model 7905-30 horizontal integral cryostat in a $30-\mathrm{L}$ dewar. A preamplifier is integrally mounted on the detector cryostat. Optionally, a cryolectric cryostat may be used. The detector is housed in a combination collimator/shield, which isolates the detector from unwanted background radiation, while providing an accurately collimated window allowing the detector to see only the segment of the container being measured. This shield uses $3 \mathrm{in}$. of lead with a copper liner to eliminate the detection of lead $x$-rays and provides a slit 4 in. high $\times 8$ in. deep.

The model 2440 waste assay systems run under DOS on an IBM-compatible PC. Standalone multichannel analyzers or PC-based multichannel analyzers can be used with the system.

The primary intent of this system is for the analysis of fission product gamma-emitters such as Cs-134, Cs-137, and Co-60; however, other gamma-emitting nuclides may also be analyzed. The performance is dependent on the density of the material and the data collection time. Under typical conditions with low density waste, minimum detection levels of $0.1 \mu \mathrm{Ci}(3.7 \mathrm{kBq})$ of Cs-137 can be assayed in a 55-gallon drum.

The accuracy of the instrument is based on the uniformity of the activity distribution and the density and homogeneity of the waste material. Typical accuracies are approximately $20 \%$ with maximum errors being in the range of $50 \%$ for drums with densities up to $1 \mathrm{~g} / \mathrm{cc}$.

\subsubsection{Segmented Gamma Scanner-Harwell Instruments/EG\&G ORTEC}

The segmented gamma scanner (SGS) is used to identify and measure gamma-emitting nuclides within drums of LLW. The nuclides are identified from a spectrum of the gamma rays emitted, and their activity is quantified. The spectrum of each segment of the waste container is analyzed separately, and the results are summed for total drum inventory reporting. The SGS consists of a fixed-height turntable onto which the drum to be measured is loaded. Drums up to $500 \mathrm{~kg}$ and approximately $500-\mathrm{L}$ capacity can be accommodated. Alongside the turntable, a liquid-nitrogen-cooled HPGe detector views the drum through a slot-shaped collimator. A leadscrew-operated platform is used to raise the detector and collimator enabling the drum measurement to be made in fixed vertical increments, or "segments." At a drum rotation of $10 \mathrm{rpm}$, a measurement is made on each drum segment.

Also under computer control, an ORTEC 92X Spectrum Master integrated spectroscopy system gathers the spectral data from the HPGe detector. The $92 \mathrm{X}$ is housed in a 19-in. equipment cabinet with the programmable logic controller (PLC), through which the computer controls the motorized components of the scanner.

For applications involving count rates in excess of 100,000 counts per second, ORTEC's MERCURY ultra-high-rate spectroscopy system is available as an option. The system can operate at count rates in excess of 400,000 counts per second, and still reportedly return accurate activity results. 
The standard HPGe detector for the SGS system is an ORTEC GEM-30195 coaxial, with the following warranted specifications:

\author{
Energy range \\ Relative efficiency at $1.33 \mathrm{MeV}$ \\ Energy resolution at $1.33 \mathrm{MeV}$ \\ Energy resolution at $122 \mathrm{keV}$ \\ Peak to compton ratio
}

\author{
$40 \mathrm{keV}$ to $10 \mathrm{MeV}$
}

$$
\begin{aligned}
& >30 \% \\
& <1.95 \mathrm{keV} \\
& <1100 \mathrm{eV} \\
& >54: 1
\end{aligned}
$$

Peak shape

FW.1M/FWHM
FW.02M/FWHM
$<1.98$

$<2.98$.

The detector is mounted in an aged-lead collimator, which restricts its field of view to a single slice or segment of the waste container. To avoid measuring background from waste containers nearby, a collimator assembly provides all-around shielding for the detector element. If it is necessary to store highly active drums nearby, additional shielding may be required.

The HIGA modules that perform the SGS-specific data analysis extensively use the ORTEC OMNIGAM package to analyze the SGS spectra (peak search, peak fitting, nuclide identification, and calculation of nuclide activities.) The complete software package operates in such a manner as to produce a single report for each drum measured. In addition, spectra may be viewed using the ORTEC MAESTRO II MCA emulation software, included in the system. The MAESTRO II MCA emulator provides live spectral display of data being acquired, and, for setup and diagnostic purposes, full control of the $92 \mathrm{X}$ spectrometer functions.

The standard gamma measurement time for a drum using a single $30 \%$ relative efficiency HPGe detector is 20 to 30 minutes. The detection limit of the measurement can be improved by increasing this time. The overall measurement precision improves in inverse proportion to the square root of the measurement time. Correspondingly, the measurement time can be reduced, although the sensitivity and precision of the measurement will be worse. An alternative geometry, with four detectors viewing the complete drum, can be supplied as an option, if high drum throughput is required.

The performance of the SGS in a given application depends strongly upon the nuclides to be measured (the particular mix and the energies of the gamma rays produced), the waste density, uniformity, and measurement time. Typically, for light waste matrices (approximately $0.2 \mathrm{~g} / \mathrm{mL}$ ) and a 30-minute drum measurement time, the lower limit of detection for Pu-239 is $0.2 \mathrm{~g}$ and approximately 0.13 to $0.27 \mu \mathrm{Ci}(5$ to $10 \mathrm{kBq}$ ) for $\mathrm{Cs}-137$ and $\mathrm{Co}-60$. Under the same conditions, an accuracy of about $10 \%$ is typical for the measurement of $5 \mathrm{~g}$ of $\mathrm{Pu}$ or $2.7 \mu \mathrm{Ci}(100 \mathrm{kBq})$ of Cs-137 or Co-60.

Drum surface gamma dose rates are measured using industrial ion chamber survey meters covering the $5 \mathrm{mrem} / \mathrm{hr}(50 \mu \mathrm{Sv} / \mathrm{hr})$ to $500 \mathrm{R} / \mathrm{hr}(5 \mathrm{~Sv} / \mathrm{hr}$ range). These are supplied with a $6 \mathrm{Vdc}$ power supply and readout to the system PC through an RS-232 serial line. The array of dose 
meters is mounted on a pillar viewing the drum cylindrical surface, and the measurement is carried out in parallel with the main gamma scanning measurement. An additional option allows monitoring of the top and bottom surfaces of the drum.

\subsubsection{Model JCC-92 Passive/Active Neutron Shuffler System - Canberra Nuclear}

This system uses a high-speed transfer mechanism to shuffle a Cf-252 interrogation source between a source shield assembly and the counting chamber, giving it the ability to be used for both passive and active neutron coincidence counting of fissionable materials. The JCC- 92 is based upon a design by Los Alamos National Laboratory (LANL), and is available commercially from Canberra's Applied Systems Division through a technology transfer agreement with LANL.

Because shuffler-type instruments can be used for the nondestructive assay of small amounts of both uranium and plutonium in a wide variety of forms and matrix materials, they are recommended for analyzing waste materials produced by facilities that handle fissile material. In addition, the design and size of systems such as the JCC-92 allow them to also be used for samples as large as a spent fuel assembly, although the presence of large amounts of activation products makes gamma assay impractical.

The counting chamber of the JCC-92 has an interior cavity large enough to contain a 55-gallon drum. The drum sits on a turntable, which rotates at $3 \mathrm{rpm}$ while the count is in progress. When the door to the counting chamber is closed, the drum is surrounded by a shield of tungsten, high-density polyethylene, and boron-loaded polyethylene weighing approximately $8,000 \mathrm{lb}$. Imbedded in the shielding are $64 \mathrm{He}-3$ tubes, giving the system a very high counting efficiency.

The Cf-252 source, which nominally provides $8 \times 10^{8}$ neutrons/s, is housed in its own 4,000-lb shield located above the counting chamber. A Teleflex cable, which is driven by a computer-controlled stepper monitor, is used to rapidly transfer the source between its shielded housing and the counting chamber. Less than $400 \mathrm{msec}$ are required to insert or remove the source, and safety interlocks ensure that the counting chamber door is closed before the source is transferred into its sample interrogation position.

While the nature of the sample and exact shuffle/count times used will affect the results, 1,000 -second measurement times have yielded sensitivities of $300 \mathrm{mg}$ of U-235 contained within a 55-gallon drum. By removing the cadmium liner from the counting chamber and counting the thermal neutrons that are produced, sensitivities down to $20 \mathrm{mg}$ of U-235 have been obtained. These sensitivity levels improve when operating in areas of low background activity and with a larger Cf-252 source.

\subsubsection{BM-286 Barrel Monitor - TSA Systems, Ltd.}

The BM-286 barrel monitor instrument is designed to measure gamma content of containerized material. The BM-286 is designed to hold 55-gallon drums of up to $1,000 \mathrm{lb}$.

A stainless steel liner protects the detectors from the articles being monitored. The load platform, containing the weight monitoring load cells, is mounted on sliding runners to facilitate 
the loading of heavy samples. Six plastic scintillation detectors are mounted top, bottom, left, right, back, and door to provide uniform measurement throughout the chamber. Radiometric identification of radioactive material is possible with an optional NaI detector, multichannel analyzer, and applicable software.

The large size of the unit permits monitoring of large amounts of material in a minimum number of operations. The high sensitivity of the unit derives from large surface area plastic detectors, coupled with microprocessor controlled electronics and software algorithms.

From the PC, the operator can change monitoring time, background measurement time, high-alarm level, and low-alarm level. Changes in system operating parameters are password protected. Report generation is automatic and continuous.

The detectors for the BM-286 include four plastic scintillation detectors, $12 \times 36$ in. each (left, right, back, and door) and two plastic scintillation detectors, $12 \times 24$ in. each (top and bottom) with optional $3 \times 3$-in. NaI detector for spectral measurements.

The range in gamma energies is $40 \mathrm{KeV}-1.6 \mathrm{MeV}$ with a window adjustment of $0 \mathrm{KeV}-1.6 \mathrm{MeV}$.

\subsubsection{Segmented Gamma-Ray Scanner - Atlan-Tech, Inc.}

The segmented gamma-ray scanner is a completely self-contained system for assaying general gamma-emitting radionuclides in steel containers or transuranics in low density materials.

The basic subsystem components and configuration are essentially the same as the AtlanTech, Inc. MBS-550 waste barrel assay system and will be partially restated here for clarity.

A shielded detection subsystem accommodates the barrel handling system on which the analysis is to be performed. This portion of the system contains the radiation detector and the shielding that is interposed between the detector and background sources of radiation to optimize the ability of the system to detect and distinguish very low levels of photons emitted by small amounts of radioactive material.

The scanning table presents the sample material to be counted in front of the detector in an optimum geometry. A circular platform that is designed to accommodate a wide variety of sample containers rotates at a fixed speed to help minimize the effects caused by geometry. A rail system powered by a stepper motor and ball screw moves the container in incremental vertical steps so that the detector can scan a series of segments of the container. All motion is controlled by the computer and control software.

A transmission source system provides a method to determine the density of the material being assayed by the detector. The system shines a beam of gamma radiation through the sample container to the detector from a radioactive source of known activity. By measuring the amount of activity viewed by the detector, the density of the sample material can be determined and a correction factor be applied to the radioactive material found during the analysis. 
The remaining system supports the pulse height analysis, spectrum analysis computation, and reporting functions. A multichannel analyzer incorporates an ADC to detect and count signal pulses corresponding to the interaction of photons with the detectors.

The computer system controls and monitors all aspects of the barrel scanner during operation. After the assay is complete, the spectroscopy software performs a peak search of the spectrum, determines the type and amount of radionuclides, applies correction factors based on density, and stores the results. While Atlan-Tech provides the complete hardware system and the basic operating software, LANL provides the system control software and the spectroscopy software.

The segmented gamma-ray scanner system consists of the following components:

\begin{tabular}{|c|c|}
\hline Model & Description \\
\hline NA & Detector shielding and collimator \\
\hline NA & Scan table \\
\hline NA & Transmission source holder \\
\hline NA & Safety and contamination enclosure \\
\hline GEM-18180-P & Detector \\
\hline Ortec 659 & HV supply \\
\hline Ortec 572 & Amplifier \\
\hline Ortec LNP-30D & Liquid nitrogen probe \\
\hline Ortec 871 & Counter/timer \\
\hline Ortec $729 \mathrm{~A}$ & LN2 monitor \\
\hline Ortec $4001 \mathrm{~A} / 4002 \mathrm{D}$ & NIM bin/power supply \\
\hline Tektronix 2225 & Rack-mount oscilloscope \\
\hline 4000 & Computomotor indexer \\
\hline S106-178 & Computomotor motor/driver \\
\hline S106-205 & Computomotor motor/driver \\
\hline Opto PB24 & I/O modules and card \\
\hline Topaz Escort & AC power conditioner/voltage regulator \\
\hline \multirow[t]{2}{*}{ Designline 2} & Instrument rack \\
\hline & Software exerciser program \\
\hline Canberra XG-3100F & Genie workstation \\
\hline Canberra 861733 & DEC VT340 terminal \\
\hline Canberra 862199 & DEC LA-75 printer \\
\hline Canberra 8233 & Two point digital stabilizer \\
\hline Canberra 8706 & $450 \mathrm{MHz}$ Wilkinson ADC, $16 \mathrm{~K}$ channels \\
\hline
\end{tabular}

The scan table serves to position the sample in the proper counting geometry in front of the detector. The table both rotates and moves vertically. When in the load position, the top surface of the scan table is $19 \mathrm{in}$. above the floor. The top of the rotating turntable is flush with the nonrotating part of the scan table, which in turn is even with an adjacent platform raised 19 in. above the floor. The table is designed to allow a circular drum dolly to roll from the platform onto the scan table with minimal effort. Locating pins position the dolly and barrel in the center of the turntable. After the dolly is in place, a locking pin is inserted to lock the dolly and barrel in the center of the turntable. 
The scan table is 30 in. in diameter and can accommodate samples up to 30 in. in diameter and 48 in. tall. Although the scan table is designed to safely carry a weight of $750 \mathrm{lb}$, the maximum recommended sample weight is $500 \mathrm{lb}$. The total vertical travel is $48 \mathrm{in}$., with an accuracy and reproducibility of better than 0.05 in. over the entire range of load and displacement. The turntable can rotate at any speed between $12 \mathrm{rpm}$ and $20 \mathrm{rpm}$.

The detector is a coaxial high-purity GE detector with the following specifications:

Type:

High purity p-type GE

Relative efficiency: 18 percent at $1332 \mathrm{keV}$

FWHM resolution: $\quad<1.80 \mathrm{keV}$ at $1332 \mathrm{keV}$

$<0.80 \mathrm{keV}$ at $122 \mathrm{keV}$

Peak shape:

FW.02M/FWHM $<2.50$ at 1332 and $122 \mathrm{keV}$

Preamplifier:

Resistive feedback preamplifier with energy rate $>145,000 \mathrm{MeV} / \mathrm{s}$

Cryostat:

Horizontal dipstick cryostat with 30 liter $\mathrm{LN}_{2}$ dewar

Detector capsule:

"Pop top" design with streamline preamplifier

Detector protection: Automatic bias disablement if detector warms up.

\subsection{Handheld/Portable Radiation Monitors}

The disposal facilities have used portable radiation monitors extensively to verify the shipper's conformance to the applicable DOT requirements. The portable instrumentation discussed within this subsection is a hand-held version, which implies that the instrument is a lightweight battery-operated variety. The three instruments summarized below only represent a small sample of the suitable instrumentation available for LLW radiation survey requirements. Each instrument is described by defining the detection system and data storage/interpretation capabilities.

\subsubsection{PRM-470A Portable Radiation Monitor - TSA Systems, Ltd.}

The portable radiation monitor, model PRM-470A, is a lightweight hand-held gamma monitor. The monitor, internally powered by nickel-cadmium batteries, features a miniaturized low-power, high-voltage power supply, and uses a low-power Computer Management Operating System microprocessor for signal analysis. It can be fitted with a $1 \times 2$-in. NaI detector or a 2-7/8 x 4 x 1-1/4-in. plastic scintillator.

The PRM-470A is especially useful for applications where high sensitivity is critical, and where frequent battery charging is not always possible because of heavy use or remote location. The simplified design allows inexperienced personnel to make consistently accurate surveys. A special software version with limited operator control access is also available. 
The detector is $1 \times 2$-in. NaI crystal or a size 2-7/8 $\times 1-1 / 4$-in. organic plastic scintillator. The alarm level has user defined settings inside the unit. In SEARCH mode, the monitor alarms continuously if radiation intensity is too high (typically over $45,000 \mathrm{cps}$ ). The counting time in SEARCH mode is 0.05 second count with a 0.4 -second moving average and the counting time in BACKGROUND mode is a 10-second interval.

\subsubsection{NNV-470 - TSA Systems, Ltd.}

The NNV-470 (non-nuclear verification) is a gamma-neutron sensitive version of the PRM-470A. The basic electronic package is identical, with the exception of the detector assembly. The gamma sensitive NaI or plastic scintillator is replaced with a thin $\mathrm{LiI}(\mathrm{Eu})$ detector, which is shielded by a neutron thermalizing plastic to achieve neutron sensitivity. A "calibrate" switch accesses a low-level discriminator to allow gamma counting to verify instrument operation.

The NNV-470 unit was designed specifically to verify neutron flux in high gamma backgrounds, as would be the case in SNM environments. The design of the NNV-470 allows a gamma check source to be used to verify proper instrument operation on power-up and then automatically switch to neutron measuring mode without operator input. Operation is very similar to the PRM-470A.

All NNV-470 specifications are identical to the PRM-470 in terms of size, weight, battery life, and back-lighted display. Counting timers and sequencing of gamma and neutron count rates are factory-changeable to meet operator requirements. The NNV-470, in addition, features a fold-over handle for ease of transporting.

\subsubsection{Portable Hand-Held Multichannel Analyzer MCA-465 - TSA Systems, Ltd.}

The MCA-465 provides a full-featured 256-channel MCA in a portable, battery-powered package. The MCA-465 can be fitted with an internal NaI crystal or used with a variety of external probes. The MCA-465 has 256 x 128-pixel liquid crystal display to view the spectral data graphically or to check parametric information during set up and calibration. User interface is provided via eight membrane switches on the front panel of the instrument. These switches provide operator access to all functions of the MCA- 465 through a series of menus.

Access to the set up is controlled by an internal dip switch setting. This allows the customer to control whether the operator can access the set up mode or only collect data. From the setup mode a "field calibration" may be performed. This allows fine tuning the gain from the front panel of the instrument. The field calibration requires the use of an external source, and allows the operator to place the energy peak in precisely the desired channel.

The MCA-465 provides both real-time and live-time modes of operation. The MCA further provides four user programmable regions of interest (ROIs). The ROIs are set by channel number from the ROI setup menu. The MCA-465 can store 14 scans in its nonvolatile memory. The scans are labeled as background or data scans by the operator, and are automatically time and date stamped from the internal clock/calendar. These scans may be recalled for viewing on screen, or downloaded to a PC using the communications package. 


\subsection{Small Container/Bag Monitors}

The instruments summarized within this subsection are examples of the typical detection systems used for radiological screening of small containers and bags.

\subsubsection{Small Articles Monitor SAM-1 - TSA Systems, Ltd.}

The SAM-1 small articles monitor is an instrument designed to measure gamma contamination on any articles that can be placed within its $15 \times 15 \times 18$-in. chamber. Hard beta detection can be achieved with detector/liner modifications. A removable stainless steel liner protects the detectors from the articles being monitored. The four detectors and electronic subassemblies are mounted on a slide-out runner mechanism, providing accessibility for maintenance.

The unit's high sensitivity and accuracy result from its composite shielding materials, large area plastic scintillation detectors, and software algorithms.

The hand-held terminal (supplied) allows the user to adjust all of the system parameters once the password is entered. Changes can be made to monitor time, alarm level, false alarm rate, confidence level, and delta background sigma value, or system test functions can be run displaying counts, variance, or calibration routines.

The SAM-1 is easy to set up and use. Once set in operation, only routine checks will be required, as the detector system used displays a high degree of stability.

The SAM-1 includes 3/4-in. lead detector shielding and a hand-held terminal for set up. The SAM-1B includes 3/8-in. lead detector shielding and a hand-held terminal.

Performance

Monitor time

20 seconds

Probability of false alarm

$5 \%$

Probability of detection

$95 \%$

$1.6 \mathrm{nCi} \mathrm{Co-60} \mathrm{in} \mathrm{center} \mathrm{of} \mathrm{chamber} \mathrm{in} 10 \mathrm{uR} / \mathrm{hr}$ background

$3.5 \mathrm{nCi} \mathrm{Co}-60$ in center of chamber in $50 \mathrm{uR} / \mathrm{hr}$ background

Overall system efficiency $21 \%$ to Co-60 in center of chamber.

\section{Detectors}

Plastic scintillation

Number of detectors

Total detector volume

$10 \times 15 \times 1.5$ in.

4

$900 \mathrm{in}^{3}$

Location-both sides, top and bottom

\section{Range}

Gamma energies

Threshold adjustment

$40 \mathrm{KeV}-2.0 \mathrm{MeV}$

Window adjustment

$0 \mathrm{KeV}-2.0 \mathrm{MeV}$

$0 \mathrm{KeV}-2.0 \mathrm{MeV}$. 


\subsubsection{BM-285 Bag Monitor - TSA Systems, Ltd.}

The BM-285 bag monitor is designed to measure gamma contamination of containerized material. The BM-285 can accommodate containers of up to $400 \mathrm{lb}$.

A stainless steel liner protects the detectors from the articles being monitored. The load platform, containing the weight monitoring load cells, is mounted on sliding runners to facilitate the loading of heavy samples. Six plastic scintillation detectors are mounted top, bottom, left, right, back, and door, to provide uniform measurement throughout the chamber. Radiometric identification of radioactive material is possible with an optional NaI detector, multichannel analyzer, and applicable software.

The large size of the unit permits monitoring of large amounts of material in a minimum number of operations. The high sensitivity of the unit derives from large surface area plastic detectors, coupled with microprocessor-controlled electronics and software algorithms.

From the PC, the operator can change monitoring time, background measurement time, high alarm level, and low alarm level. Changes in system operating parameters are password protected. Report generation is automatic and continuous.

After the unit has been powered up long enough for a background count to be taken, monitoring is automatic whenever the door has been opened and reclosed, and weight is detected on the platform. When the chamber is empty, the unit continuously updates background radiation.

The detectors for the BM-285 include six plastic scintillation detectors, $12 \times 19$ in. each (left, right, back, door, top and bottom) with an optional $3 \times 3$-in. NaI detector for spectral measurements.

\subsection{Radioscopic/Tomographic Waste Inspection Equipment}

The radioscopic/tomographic waste inspection equipment is capable of verifying waste forms in order to demonstrate generator compliance with the LLW facility WAC. This subsection describes the state-of-the-art radioscopic/tomographic systems that are available for real-time radiography analysis of LLW containers. The systems consist of an x-ray generation unit and a camera-based viewing system. The systems are very expensive in comparison to the previously described instrumentation. Each system is described by identification of the main components followed by a brief description of the operating advantages.

\subsubsection{ISOCON Camera-Based Imaging System - LumenX Company}

The LumenX Company has developed a radioscopic system designed to meet the imaging demands of the hazardous and radioactive waste management industry. This system is capable of handling drums up to $10,000 \mathrm{lb}$. Container handling requirements from manual loading to fully automated remote conveyorized handling are also taken into account. The major components and subsystems are: 
- ISOCON camera-based imaging system

- Container handling and manipulation system

- Imaging and $\mathrm{x}$-ray unit manipulator

- $\quad \mathrm{X}$-ray generation unit

- Radiation enclosure

- Ergonomically designed control system.

The system is manufactured using a modular design concept that is supported with a high level of documentation. In addition, the inclusion of digital and analog image recording, data archival, digital image processing and video accessories, etc., can be accommodated.

It is necessary for the radioscopic technique, also referred to as real-time radiography, to discern low- and high-density objects adjacent to each other in the same scene. The ISOCON camera-based imaging system has a wide dynamic range of 10,000 to 1 . This gives the ability to reproduce information in very dark areas of the image that is surrounded by or adjacent to intense highlights.

The ISOCON camera-based system is able to view a large area of the waste container at one time. This feature improves the operator's ability to interpret the radioscopic image with the added benefit of reducing the inspection time. In addition to the large field of view, the ISOCON camera-based system exhibits a uniform and distortion free image. The light intensity is the same in the center of the radioscopic scene as it is at the edges.

The ISOCON camera-based system has a high resolution capability and contrast performance. Since resolution and contrast are interrelated, both image characteristics are required to produce the high quality image demanded in the $\mathrm{x}$-ray inspection of waste.

Additionally, the system exhibits a low inherent noise level. Little or no video frame integration is required to produce a noise-free image, making the detection of free liquids easily achieved. The detection of free liquids is accomplished by the introduction of a jogging or vibrating action into the container manipulator during the radioscopic inspection. The operator determines the presence of liquid by simply noting the movement of the liquid within the image.

The system is manufactured under a program that takes into account industrial codes and standards such as NEC, NEMA, OSHA, AISC, and 21 CFR 1020.40.

\subsubsection{Waste Inspection Tomography System - Bio-Imaging Research, Inc.}

Bio-Imaging Research, Inc. (BIR) and LANL will be developing the waste inspection tomography (WIT) system through funding from DOE for a research and development and demonstration program, directed by the Morgantown Energy Technology Center. In a five-phase, two-and-a-half year program, a mobile WIT system will be developed that can be used at any site 
where characterization of new or previously stored drums is required. The WIT system will be based on the following inspection technologies:

- $\quad$ Transmission x-ray computed tomography (CT)

- Active and passive gamma-ray CT

- $\quad$ Single photon emission CT

- Gamma-ray spectrometry.

Transmission CT will be used to determine the presence and quantity of free liquids in a drum that could cause corrosion and leakage. The transmission CT can also be used to identify densities and locations of nonradioactive materials in the drum, heavy metals, and drum wall thickness. The emission techniques can identify and locate radionuclides in a drum, measure external radiation levels, identify internal radiation shielding, and calculate internal radiation.

BIR is currently investigating the use of two advanced $x$-ray imaging techniques for characterizing containers of solidified radioactive waste. These techniques, digital radiography and CT, are performed by computerized imaging systems that can automatically inspect containers using a set of imaging parameters chosen by the operator. Both inspection techniques can be performed by the same imaging system. The inspection result is a computer image, or series of images, that can be manipulated by the operator to show a wide variety of features within the inspected object.

WIT offers both two-dimensional and three-dimensional imaging results. Inspection will be fast (with a throughput of up to four drums per hour) as well as non-invasive. The digital data collection offers sophisticated image review capabilities.

The choice of radiological or radiographic instrumentation must be based on a number of considerations. Among these considerations are the typical form of wastes being disposed, the type of packaging, and the overall volume of waste generated on an average basis by a facility. Large-scale multi-drum handling systems may not be cost-effective for medium or small volume LLW generators, and a hand-held instrument or small article monitor may prove more effective for a limited volume application. Large volume generators, however, may actually save time and money in the long run by using a system that can efficiently and effectively handle a large number of drums in a reasonable time frame. Fortunately, the wide variety of applicable instrumentation available on the market enables one to select the instrumentation that most suits the needs of the specific facility, however large or small. 



\section{MODEL INSPECTION AND VERIFICATION PROGRAM}

A key goal of this report is to develop a model inspection and verification program (MIVP) that suggests program elements that could be practically adopted by a regulator or operator responsible for the oversight of newly developed or existing LLW disposal facilities. The overall objective of the MIVP, therefore, is to provide a reasonable degree of assurance that LLW received for disposal meets the applicable WAC, thus ensuring that the performance objectives of 10 CFR 61, Subpart C, are met.

The performance objectives of 10 CFR 61, Subpart C, require LLW disposal facility operators to comply with the radiation protection standards in 10 CFR 20, and to make every reasonable effort to minimize radiation exposure to workers, including inspection personnel, ALARA. In addition, annual radiation dose equivalents to any member of the public resulting from radioactive material releases must not exceed 25 millirems to the whole body, 75 millirems to the thyroid, and 25 millirems to any other organ. Releases of radioactive material are primarily postulated to occur following closure of new engineered disposal facilities. The releases are a natural consequence of the gradual degradation of the waste containers and the waste form, which have been designed to impart long-term stability to the waste. Many of the WAC established for disposal facility operations are intended to contribute to the overall performance of the disposal facility by ensuring long-term stability of the waste.

To attain a reasonable degree of assurance that the WAC have been met, specific inspection and verification requirements should be established that are determined by the regulator or operator as necessary for a given disposal facility accepting variable types and quantities of LLW streams. These requirements could include both operational and administrative inspection and verification measures. To minimize the impact on waste generators, the incurred cost of the inspection and verification requirements should remain reasonable, adding only an incremental cost to the existing unit price of LLW disposal.

Given that the long-term environmental factors affecting the performance of a disposal facility are geographically variable and that these factors drive the long-term performance requirements of waste packages, the waste container and waste form acceptance criteria may vary somewhat by facility. Although the essential qualities of a MIVP can be defined, it would not be practical to recommend a uniform set of specific inspection and verification procedures applicable to all LLW disposal sites. It is also possible that the nature of the waste streams received for disposal and the affordable state-of-the-art technology for verification may significantly change during the operating life of a facility. This suggests that the inspection and verification program should be periodically reviewed for adequacy, and that the overall program should provide for timely revision of its components.

Therefore, four objectives for developing the MIVP are to:

- Keep radiation doses to inspection personnel ALARA

- Verify waste characteristics and waste packaging in accordance with long-term performance requirements 
- Contain the cost of the MIVP so that it adds only incrementally to the unit disposal price

- Apply it to all LLW disposal sites and allow it to be periodically reviewed and revised as required to match changes in incoming waste streams and the level of affordable verification technology.

The MIVP presented in this report is primarily intended to provide a compilation of actual and potential inspection and verification practices for consideration by regulatory agencies and operators at commercial LLW disposal facilities. The MIVP is not intended to imply that the existing inspection and verification programs are deficient. In this regard, the licensing representatives of both the State regulatory agencies and the disposal facility operators contacted while preparing this report uniformly pointed out that existing inspection and verification policies and procedures provide more than adequate assurance that received waste complies with respective disposal site WAC. They cited the low rates of waste package noncompliance actually experienced at the facilities as compelling evidence to support this conclusion. The MIVP is merely an alternative with some possible enhancements to current inspection and verification programs that incorporates many elements of current programs to provide reasonable assurance that treated LLW will comply with applicable WAC.

\subsection{Model Inspection and Verification Program Development}

Development of the MIVP was based on an analysis of supporting information that included:

- The existing commercial LLW disposal facility inspection and verification programs conducted by disposal facility operators discussed in Section 4

- The Washington Department of Health Point of Origin Inspection Program discussed in Section 4

- Available waste assay instruments and waste form verification technologies presented in Section 5

- A review of DOE LLW disposal site WAC and certification program documents.

The components and relative merits of each of the above programs, as well as the instruments and technologies, were evaluated for their relative contribution toward meeting the four objectives of the MIVP. Based on this evaluation, the most functional and cost effective elements were incorporated in the MIVP.

\subsection{Structure of the Model Inspection and Verification Program}

The MIVP provides multiple assurance measures for WAC compliance. Disposal facility inspection and verification procedures currently used by all facilities could remain essential elements of the program. The primary differences between the MIVP and the current commercial site programs focus on the integration of a number of administrative program 
measures aimed at providing assurance of WAC compliance before site access is granted to the generator, and the addition of a generator inspection program. Incorporation of these elements can be a favorable alternative to increasing the frequency of disposal facility inspections, particularly opening packages for internal verification of waste characteristics, which increases personnel exposure. Additional administrative measures and generator inspections can also provide verification of WAC compliance with only minimal or no increase in personnel exposure.

An administrative program could be implemented for the purposes of reducing radiation dose to workers involved with handling this material (an administrative control program). Each generator could be requested to submit an application to be preapproved to ship LLW. This application would be reviewed by the disposal facility operator and/or facility regulator for completeness. Within the application, the following items could be described in detail:

- Generator information (identification numbers, names, and contacts)

- Waste certification program

- Waste stream characterization plan

- Procedures and documentation

- Variances.

The disposal facility operators and/or facility regulator could review the application and possibly conduct an audit. A cost-benefit analysis could be required to determine what volume and frequency of LLW shipment would justify a generator site audit.

Unannounced audits, surveillance, and inspections could also be incorporated into the generator application process. Upon receipt of an application to dispose of LLW in accordance with the disposal facility WAC, the facility operator and/or facility regulator could require a generator site audit as part of their decision process. A re-audit of the generator could be performed if necessary. Whenever a significant change in the waste stream occurs at a generator facility, a recertification could be required. The waste would be recharacterized and certified. In addition to this recertification requirement, some generators could be required to submit periodic recertifications on all waste streams disposed at the LLW facility.

If the disposal facility or facility regulator determines significant findings after completing the application review and the generator site audit, corrective action could be required. Upon review of the findings from the audit process, a decision by the disposal facility manager or facility regulator would approve or reject the application.

Each generator could be required to submit a completed application package in conformance with the LLW facility WAC. The general requirements of each key item of the application is discussed in the following paragraphs. 


\subsubsection{Generator Information}

The following information could be required in this section of the application:

- Generator/facility name and location

- $\quad$ Primary contacts (radiation safety officer, facility manager).

Updates on these items could be required when any changes occur.

\subsubsection{Waste Certification Program}

Each LLW generator could be required to certify that any waste to be sent to the disposal facility meets the WAC. The elements of the waste certification program should provide assurance that DOT, NRC, and State regulations are met. Sufficient detail should be presented to demonstrate knowledge and experience in the subject area. The waste certification program should fit within the generator's established site organizational structure.

The objectives of the waste certification program are to:

- $\quad$ Require generators to properly identify and characterize the material

- Provide a system for transmitting information about wastes to the LLW disposal operator

- Provide an auditable system for verifying that the generators are properly characterizing their wastes.

The waste application process includes an audit function. This audit could also review the generator waste certification program. The generator should also prepare a plan for implementing the waste certification program.

The waste certification program requires that an individual having the appropriate authority and knowledge sign a certification statement. This individual would become the generator's certification official. This official would be responsible for certifying that each package meets the WAC, NRC, DOT, and State regulations.

As part of the waste certification program, the generator would be required to submit a quality assurance (QA) program. The requirements may include that an independent group be assigned within the generator organization to oversee activities involving packaging, characterization, certification, storage, and shipping of LLW. A general statement of the generator's QA policy and independence of this function should also be included. A functional organization chart would also be requested. The QA program should be developed in accordance with ANSI/ASME NQA-1 or other applicable QA standards acceptable to the regulatory agency. 


\subsubsection{Waste Stream Characterization Plan}

The waste stream characterization plan consists of methods and procedures to verify that the waste meets the WAC. The characterization plan should include a waste sample and analysis plan, which include the following items:

- Sample collection methodologies suitable to the types of waste being sampled. The number location and frequency of sampling are addressed.

- Descriptions of containers to be used for sampling, sample handling, packaging, and transport procedures

- Laboratory analysis to be performed for each sample to include the analytical methods, instrument calibration requirements, and laboratory quality control program

- Method for interpreting the analytical data.

The characterization plan should also address the analysis of incompatible waste forms. If the waste form is a difficult-to-sample physical form, or if there are other hazards preventing sampling, the indirect methods for determining radionuclide content should be presented, such as knowledge of process and conversion of gamma ray constants.

\subsubsection{Procedures and Documentation}

Activities critical to verifying that the LLW meets the disposal facility WAC require procedures and documentation under a controlled management system. Processes or functions requiring designs, instructions, or procedures need to be maintained and kept current. A document control system could be requested by the LLW disposal facility operators or regulator for the control of documents.

\subsubsection{Variances}

The model program described within this section may not be ideal for each type of LLW generator. Variances may be necessary for some generators. A program similar to the limited resource generator provision under the Resource Conservation and Recovery Act could be considered. There are a large number of LLW generators that fall into this category. Special provisions considering the cost impact and value gained from the administrative requirements of this program would need to be evaluated case by case.

\subsubsection{Generator Inspection Program}

The Washington Department of Health, Division of Radiation Protection, recently initiated a generator inspection program (described in Section 4 of this report) where waste generated or processed is inspected before the waste is shipped to the disposal facility. The basic principles involved in a generator inspection program provide an added measure of assurance of WAC compliance. The merits of the generator inspection program are that it: 
- Allows direct verification of waste stream contents through knowledge of the process that generates the waste

- Permits direct assessment of the adequacy of the generator's characterization program

- Permits independent evaluation of waste stream sampling and analysis results

- Provides an opportunity to educate the generator about the underlying reasons for the various WAC

- Provides face-to-face communication between the regulator/facility operator and the generator, which is likely to promote trust and respect for the problems encountered by each party.

The overall benefit of a generator inspection program is that it might permit a significant reduction or elimination of inspections at disposal facilities, thereby potentially reducing personnel exposure, while greatly increasing the level of assurance that the waste complies with the applicable WAC.

\subsubsection{Disposal Facility Inspection Program}

Historically, commercial LLW disposal sites have relied on two major methods to achieve compliance with the WAC contained in license conditions:

- Disposal facility verification of the waste by random package selection and breach of waste packages to visually inspect the waste form, and possibly sample and analyze the waste for nuclide and chemical content

- The deterrence associated with penalties, including refusal of waste and continued denial of access to the site, imposed on generators whose waste is determined to be noncompliant.

The disposal facility method could be termed "after-the-fact," since verification does not occur until after the waste has been shipped to the disposal site. This method incorporates only a single point of inspection in the WAC verification program, and relies heavily on the package selection frequency being high enough to accurately reflect the rate of noncompliance. And, without remote handling, sampling, and analysis technology, it also necessarily involves the exposure of inspection and verification personnel to potentially high radiation dose rates. While continued use or some modification of this method would appear to provide ultimate assurance of WAC compliance and create a deterrent against noncompliance, the attendant personnel exposure and relative uncertainty of unopened waste package contents could justify improved verification methods.

The deterrence by penalty method is a valued component of a compliance verification program, especially given the rapidly escalating unit price of LLW disposal and the limited site access currently experienced by generators. This method should continue to be used by current and future commercial LLW disposal facilities. 


\subsection{Revisions to the Model Inspection and Verification Program}

The MIVP should be updated to incorporate any changes in the regulatory performance requirements. The performance objectives for LLW facilities are defined to 10 CFR 61 in Section 2 of this report. The key elements of the MIVP can change according to regulatory mandate or other socioeconomic conditions relating to cost. It is recommended that a proactive program, such as the MIVP, be continuously updated to reflect the current activities. 



\section{CONCLUSION}

This report presented a summary of the methods for verifying that LLW received at commercial disposal facilities complies with the applicable WAC. The applicable WAC include basic criteria related to:

- $\quad$ Proper preparation of the waste for transport as required by 10 CFR 20.311

- $\quad$ Correct packaging in accordance with 10 CFR 71 and 49 CFR 173

- $\quad$ Proper classification of LLW

- Characterization

- Stabilization as required by 10 CFR 61.55 and 61.56 , respectively.

In addition to these basic criteria, individual host States and LLW disposal facilities impose WAC especially with regard to stability that are intended to support the disposal facility's longterm performance capability. A trend of near-surface LLW disposal is toward a more prescriptive regulation of facility design and operation, including strict requirements on waste form to enhance stability of the disposal units.

LLW generators conduct internal waste verification programs to ensure that LLW shipped for disposal, whether directly or through a waste processor, complies with applicable disposal facility WAC. Commercial nuclear utilities appear to conduct the most extensive waste verification programs, including strict $\mathrm{QC}$ programs, to ensure that waste sent to processors is completely solidified and absent of free-standing water, and that waste streams are correctly characterized.

LLW disposal facilities conduct rigorous inspection and verification programs to ensure that waste received for disposal is in full compliance with applicable WAC, including those WAC that are established by regulations of the NRC, DOT, and host States. The disposal site WAC are contained within the radioactive materials licenses issued to the sites by the host State regulatory agency. In some cases, the host State conducts an independent verification program at the waste generator locations as overall QC on LLW destined for disposal at the host State facility. The individual LLW disposal facilities conduct their verification programs in accordance with detailed waste inspection procedures. Incoming waste that is in noncompliance with the site WAC may result in rejection of the shipment and possibly denying the generator future access to the disposal facility. The existing commercial LLW disposal facilities that are currently accepting waste implement inspection and verification programs that are intended to maintain compliance with the majority of the requirements of 10 CFR 61.

A MIVP was developed to summarize the key elements of meeting a LLW disposal facility WAC. The model program focused on the generator's ability to provide a program that will ensure that the LLW types are properly characterized and certified to be in conformance with the WAC and with DOT, NRC, and host State regulations. 
There is a wide variety of instrumentation and equipment available to support the verification of waste acceptance criteria. This equipment is commercially available to both LLW generators and the LLW disposal facilities. In general, the more complex instrumentation is being used on a limited basis at the disposal facilities. Instrumentation and equipment vendors have developed a wide variety of state-of-the-art barrel monitors and hand-held portable radiation monitors designed to provide accurate assays of waste package contents. The development of systems such as the segmented drum scanners can provide detailed quantitative radiological analyses with a high throughput and a significant decrease in worker exposures during handling. At present, several technologies are used for inspecting large waste containers such as drums. Among these technologies are coring, digital radiography, real-time radiography, hardness testing, computed tomography, and lately, the use of ultrasonic imaging, which is still in the development stage. 


\section{REFERENCES}

6 NYCRR 383, "Regulations for Low-Level Radioactive Waste Disposal Facilities" (Design, Construction, Operation, Closure, Post-Closure, and Institutional Control).

Canberra Nuclear Products Group, Meridian, Connecticut, personal communication, March 1993.

Chem-Nuclear Systems, Inc., Disposal Criteria, Document No. S20-AD-010.

Code of Federal Regulations, Title 10, Part 61, "Licensing Requirements for Land Disposal of Radioactive Waste," Office of Federal Register, 1993.

Code of Federal Regulations, Title 10, Part 20, "Standards for Protection Against Radiation," Office of Federal Register, 1992.

Code of Federal Regulations, 49 CFR Part 173, "General Requirements for Shipments and Packaging," Office of Federal Register, 1992.

Code of Federal Regulations, Title 10, Part 71, "Packaging and Transportation of Radioactive Material," Office of Federal Register, 1992.

Eberline Instrument Corporation, Santa Fe, New Mexico, personal communication, March 1993.

EG\&G Nuclear Ortec, Oak Ridge, Tennessee, personal communication, March 1993.

Nevada State Health Division Radioactive Material License Number 13-11-0043, Amendment No. 13, issued to U.S. Ecology, Inc., Beatty Site.

New York State regulation, 6 NYCRR Part 382, "Regulations for Low-Level Radioactive Waste Disposal Facilities (Certification of Proposed Sites and Disposal Technologies)," Subpart J (Sections 382.80 through 382.99).

South Carolina Department of Health and Environmental Control, Radioactive Material License Number 097, Amendment No. 45, issued to Chem-Nuclear Systems, Inc., Barnwell Waste Management Facility.

U.S. NRC Information Notice No. 90-09: "Extended Storage of Low-Level Radioactive Waste by Fuel Cycle and Materials Licensees."

U.S. NRC Generic Letter 81-38: "Storage of Low-Level Radioactive Wastes at Power Reactor Sites."

U.S. Nuclear Regulatory Commission, Low-Level Waste Management Branch Division of LowLevel Waste Management and Decommissioning, "Technical Position on Waste Form," Revision 1, January 1991. 
U.S. Nuclear Regulatory Commission, Low-Level Waste Disposal Licensing Program, Standard Review Plan, Section 4.1, "Receipt and Inspection of Waste," NUREG-1200, January 10, 1987.

U.S. Nuclear Regulatory Commission, "Branch Technical Position on Waste Form," 1983.

U.S. Ecology, letter and phone communications regarding low-level radioactive waste acceptance criteria, March 1993.

Washington Department of Health Radioactive Materials License Number WN-I019-2, Amendment No. 18, issued to U.S. Ecology, Inc., Richland facility. 
Appendix A

Samples of ConEd's Classification and Characterization Procedures 
A-2 


\section{Appendix A}

\section{Samples of ConEd's Classification and Characterization Procedures}

The following documents are included in Appendix A:

- Checklist For Vendor Process Control Program (PCP), ConEd Attachment 8.1 to procedure RW-SQ-4.007, "Process Control Program."

- ConEd Attachments 7.1, 7.2, 7.3, and Addendum 8.1 to procedure RW-Q-4.103 Rev. 3, "10 CFR 61 Waste Classification Worksheet."

- ConEd Attachments 8.1, Shipment Compliance Verification Record; 8.2 Incoming Shipment Verification Record; and Addendum 9.1, Radioactive Materials Packages Radiation and Contamination Level Limitations, to procedure RW-SQ-4.000 Rev. 9, "Shipment Final QC Inspection."

- ConEd Attachments 8.1, "CNSI Radioactive Shipment Manifest," 8.2, "USEI Radioactive Shipment Manifest" and 8.3, "Class C Waste Classification Record" to procedure TS-SQ-4.002 Rev. 5, Completion of Radwaste Shipping Manifests. 
2. PCP MEETS :
a. NRC Solidification Standards
b. Disposal Site Specifications for Dewatered OR Solidified Liquids
c. DOT Shipping Regulations
d. Con Edison Radiation Protection Procedures and Practices

YES

YES

3. PCP Contains the Following:
a. A general description of the laboratory mixing of a sample of the waste to arrive at process parameters PRIOR TO commencing the solidification process.

b.

A general description of the solidification process including type of solidification agent, process control parameters, parameter boundary conditions, proper waste form properties, AND operated WITHIN the established process parameters. This shall include a discussion of sample mixing, curing as it relates to what the full scale product will undergo and waste analysis.

c. For cement solidification, a general description of the results of Topical Report testing to satisfy the qualification test requirements for the new Branch Technical Position as summarized in Addendum 9.1. See Reference 7.16 for details. 
CHECKLIST FOR VENDOR PROCESS CONTROL PROGRAM (PCP)

d. A general description of sampling of AT LEAST one representative sample from EVERY

batch to ensure solidification AND the action to be taken IF the sample fails to verify solidification. A batch is defined as any quantity of waste from a single source (e.g., a holding tank) that is processed in a single batch, even if it is in several liners. A chemically similar but non-radioactive sample may undergo test solidification IF worker ALARA conditions warrant it.

e. The provisions to verify the absence of free liquid in solidified OR dewatered waste. A compressive strength test for PCP test specimens.

f. The provisions to reprocess containers containing solidified OR dewatered waste where free liquids are detected.

g. IF the solidification process is exothermic, the process control parameters that shall be met PRIOR TO capping the container. This includes the use of an in situ temperature probe.

h. A general description for the treatment of oily wastes that are to be transported offsite for burial.

i. As appropriate, a sketch of the process systems.

j. A statement that ALARA considerations were addressed in ALL phases of the solidification AND dewatering process.

k. A description of the dewatering technique AND control procedures (applicable to solidification liners AND HICs). 


$$
\begin{gathered}
\text { ATTACHMENT } 8.1 \\
\text { Page } 3 \text { of } 3
\end{gathered}
$$

\section{CHECKLIST FOR VENDOR PROCESS CONTROL PROGRAM (PCP)}

1. A description of provisions to reprocess wastes through the dewatering system IF excess free water is observed.

m. Sample solidification worksheet.

n. Guidance to the utility for surveillance specimen storage and testing.

4. Verification of Checklist Entries

This checklist is applicable to any shipment which utilized the attached procedures and documents and their specified revisions.

Name

Sr. Radwaste Supervisor 
RADWASTE

ATTACHMENT 7.1

\section{CFR 61 WASTE CLASIFICATION WORKSHEET}

A) Type of Waste

B) Type of Container

C) Container Burial volume $\left(\mathrm{ft}^{3}\right)$

D) Waste Volume (CC)

E) Container wt-Empty (g)

F) Media wt-Full (g)

G) Container wt-Full (g)

H) Individual Concentrations of

Key Gamma Nuclides:

Nuclide (Gamma)

Cs -134

Cs -137

Co-58

Co-60

$\mathrm{Mn}-54$

$\mathrm{Ce}-144$

Total
Total Activity

(uCi)

$$
\begin{aligned}
& \text { ( } \mathrm{ft}_{3}^{3} \times 28317=\mathrm{cc} \text { ) } \\
& \text { ( } \mathrm{ft}^{3} \times 28317=\mathrm{Cc} \text { ) } \\
& \text { (lbs } \times 454=g \text { ) } \\
& \text { (1bsx454=g) }
\end{aligned}
$$

I) Part 61 Isotope Calculation

(A)

Scaled Nuclide

(Part 61 Isotope) Scaling Factor (SF)
Specific Activity (uCi/cc)

\begin{tabular}{l|l} 
TC-99 & $\mid$ \\
\hline $\mathrm{I}-129$ & 1 \\
\hline $\mathrm{Am}-241$ & \\
\hline $\mathrm{Pu}-241$ & \\
\hline $\mathrm{Cm}-242$ & 1 \\
\hline $\mathrm{Ni}-63$ & 1 \\
\hline $\mathrm{S} r-90$ & \\
\hline $\mathrm{C}-14$ & \\
\hline $\mathrm{H}-3$ & $\mathrm{I}$ \\
\hline
\end{tabular}

J) TRU Isotope Concentration Conversion

$\begin{array}{llcl}\text { TRU Isotope Conc (Kn) } & \begin{array}{c}\text { Conversion Factor } \\ (\mathrm{KW})\end{array} & \begin{array}{c}\text { Conversion Factor } \\ (\mathrm{KC})\end{array} & \begin{array}{c}\text { TRU Conc } \\ \text { (nCi/gm) }\end{array} \\ \mathrm{Am}-241 & & 1 \times 10^{3} \\ \mathrm{Pu}-241 & & 1 \times 10^{3} \\ \mathrm{Cm}-242 & & 1 \times 10^{3} & \end{array}$

*For Solidified waste OR DAW the waste volume is EQUAL TO the Container Burial Volume: IF the waste fills the container $90 \%$ OR MORE. FOr dewatered waste the waste volume is used UNLESS the waste fills the container MORE THAN 908 full, TFEN the container burial volume is used. 
CON EDISON

INDIAN POINT STATION

RADWASTE

ATTACHMENT 7.2

Page 1 of 1

BREAKDOWN OF ISOTOPES AND ACTIVITY LESS THAN FIVE YEAR $T-1 / 2$ AND GREATER THAN FIVE YEAR $T-1 / 2$

DATE :

SHIPMENT NO:

ACTIVITY DETERMINED:

PACKAAGE NO:

DECAY CORRECTED TO:

NOTE :

NP $=$ Not Present

\section{ISOTOPES LESS THAN FIVE YEAR HALF-LIFE}

$\begin{array}{ll}131 \mathrm{II} & \mathrm{uCi} / \mathrm{cc} \\ 54 \mathrm{Mn} & \mathrm{uCi} / \mathrm{cc} \\ 134 \mathrm{Cs} & \mathrm{uCi} / \mathrm{cc} \\ 58 \mathrm{Co} & \mathrm{uCi} / \mathrm{cc} \\ 242 \mathrm{Cm} & \mathrm{uCi} / \mathrm{cc} \\ 187 \mathrm{~W} & \mathrm{uCi} / \mathrm{Cc} \\ 65 \mathrm{~N} & \mathrm{uCi} / \mathrm{cc} \\ 55 \mathrm{Fe} & \mathrm{uCi} / \mathrm{cc} \\ 59 \mathrm{Fe} & \mathrm{uCi} / \mathrm{cc} \\ 144 \mathrm{Ce} & \mathrm{uCi} / \mathrm{cc} \\ 141 \mathrm{Ce} & \mathrm{uCi} / \mathrm{cc}\end{array}$

$140 \mathrm{La}$

$125 \mathrm{Sb}$

$124 \mathrm{Sb}$

$51 \mathrm{Cr}$

$57 \mathrm{Co}$

Ag110m

Sr89

$2 r 95$

$\mathrm{uCi} / \mathrm{CC}$
$\mathrm{uCi} / \mathrm{cc}$ uCi/cc $\mathrm{uCi} / \mathrm{cc}$ $\mathrm{uCi} / \mathrm{Cc}$ $\mathrm{uCi} / \mathrm{cc}$ $\mathrm{uCi} / \mathrm{CC}$ $\mathrm{uCi} / \mathrm{CC}$ $u C i / c c$

TRU ISOTOPES GREATER THAN FIVE YEAR HALF-LIFE

$238 \mathrm{Pu}$

$239 \mathrm{Pu}$

$240 \mathrm{Pu}$

$242 \mathrm{Cm}$

$243 \mathrm{Am}$

$237 \mathrm{~Np}$
$\mathrm{nCi} / \mathrm{g}$

$\mathrm{nCi} / \mathrm{g}$

$\mathrm{nCi} / \mathrm{g}$

$\mathrm{nCi} / \mathrm{g}$

$n C i / g$

$\mathrm{nCi} / \mathrm{g}$
$241 \mathrm{Pu}$

$243 \mathrm{~cm}$

$244 \mathrm{Cm}$

$244 \mathrm{Cm}$

$241 \mathrm{Am}$

$242 \mathrm{Pu}$
$\mathrm{nCi} / \mathrm{g}$

$\mathrm{nCi} / \mathrm{g}$ $\mathrm{nCi} / \mathrm{g}$ $\mathrm{nCi} / \mathrm{g}$ $\mathrm{nCi} / \mathrm{g}$ $\mathrm{nCi} / \mathrm{g}$

Total of TRU Isotopes nci/g 
Page 1 of 2

DETERMINATION OF WASTE CLASSIFICATION WORK SHEET

Table I

I.

\begin{tabular}{l} 
NUCLIDE \\
\hline $\mathrm{C}-14$ \\
TC-99 \\
$\mathrm{I}-129$ \\
\\
$\mathrm{Pu}-241$ \\
$\mathrm{Cm}-242$ \\
TRU Nuclides with \\
T-1/2 GREATER THAN \\
Five Years \\
Total Quotient
\end{tabular}

\begin{tabular}{lc}
\multicolumn{2}{c}{ CLASS A } \\
\hline Limit & $\begin{array}{c}\text { Quotient } \\
\star \star\end{array}$ \\
\hline uCi/cc
\end{tabular}

NUCLIDE

CONC

$\underline{\mathrm{uCi} / \mathrm{CC}}$
$8 E-1$

$3 \mathrm{E}-1$

$8 E-3$

\author{
$\underline{\mathrm{nCi} / \mathrm{g}}$
}

$\mathrm{nCi} / \mathrm{g}$

$\frac{\mathrm{Ci} / \mathrm{g}}{3.5 \mathrm{E}+2}$

$2 \mathrm{E}+3$

$1 E+1$

\begin{tabular}{|c|c|}
\hline \multicolumn{2}{|c|}{ CLASS C } \\
\hline $\begin{array}{l}\text { Limit } \\
\mathrm{uCi} / \mathrm{cc}\end{array}$ & $\underset{\star \star}{\text { Quotient }}$ \\
\hline
\end{tabular}

$8 \mathrm{E} 00$

$3 \mathrm{E} 00$

$8 \mathrm{E}-2$

$\mathrm{nCi} / \mathrm{g}$

$3.5 \mathrm{E}+3$

$2 \mathrm{E}+4$

$1 E+2$

$>\overline{1.0 \text { THEN Class } C}$

$>\overline{1.0 \text { THEN waste CANNOT }}$

Table I Classification

\section{Table II}

\section{NUCLIDE \\ CONC}

II. NUCLIDE UCi/CC

$\mathrm{H}-3$

Co- 60

$\mathrm{Ni}-63$

Sr -90

Cs -137

Nuclides with

T-1/2 GREATER THAN

Five Years

Total Quotient***

\section{$\frac{\text { CLASS A }}{\text { Limit Quotient }}$}

uCi/cc

$4 \mathrm{E}+1$

$7 \mathrm{E}+2$

$3.5 \mathrm{E} 00$

$4 \mathrm{E}-2$

$1 \mathrm{E} 00$

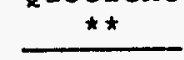

$\frac{\text { CLASS B }}{\text { Limit Quotient }}$

uCi/cc

$\star \star$

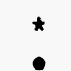

$7 \mathrm{E}+1$

1. $5 E+2$

4. $4 \mathrm{E}+1$

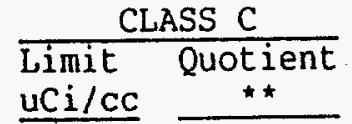

uCi/cC

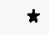

$7 \mathrm{E}+2$

$7 \mathrm{E}+3$

4. $6 E+3$

$7 E+2$
$>\overline{1.0 \text { THEN Class } B}>\overline{1.0 \text { THEN Class C }}$
$>1.0$ THEN waste CANNOT be shipped

Table II Classification

Therefore waste is 
* No Limit

* * The Quotient is the Nuclide Concentration - the Class A, B, OR C limit It is NOT necessary to list on the manifest ANY nuclide whose quotient is LESS TTAN 0.01 EXCEPT C-14, TC-99, H-3.

*** IF Class $A$ is EXCEEDED the waste is Class $B$, IF Class $B$ is EXCEEDED the waste is Class $C$, IF Class $C$ is EXCEEDED the waste CANNOT be shipped.

*** IF the waste contains a combination of Table I AND II isotopes, the final waste classification shall be:

- IF the waste is class " $A$ " in Table I THEN its final classification will be its Table II classification.

- IF the waste is class " $C$ " in Table I its final classification will be Class C UNLESS C limit in Table II is EXCEEDED.

IF the waste DOES NOT contain a combination of Table I AND Table II isotopes THEN its classification will be based on Table I OR Table II alone. 
CON EDISON

INDIAN POINT STATION

RADWASTE
$R W-Q-4.103$

Rev. 3

ADDENDUM 8.1

Page 1 of 1

FRACTIONAL ABUNDANCE OF DRY ACTIVE WASTE

(GAMMA EMITTER)

\begin{tabular}{lll} 
NUCLIDE & FRACTION TOTAL \\
\hline Co-58 & $\vdots$ & 0.09 \\
Co-60 & 0.84 \\
Cs-137 & $\vdots$ & 0.05 \\
Ce-144 & $\vdots$ & 0.02 \\
&
\end{tabular}


1. Shipment Number: Date:

2. Consignee:

Telephone :

3. Shipment Description:

4. Type of Shipment:

RADWASTE

NON-RADWASTE

5. Mode of Transport:

HIGHWAY

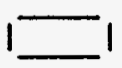

RAIL $\square$

AIRCRAFT

6. Carrier Name and Address:

Telephone:

7. Exclusive Use:

YES

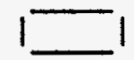

NO

8. Total Number Containers Shipped:

Package Type:

Container Type:

9. Shipment A. Vehicle (Empty)

B. Package Weight

C. Total Weight
1 bs.

1 bs.

lbs.

10. This shipment (is, is NOT) overweight for ANY state to be transited. ANY vehicle with a total weight GREATER THAN $80,000 \mathrm{lbs}$. shall have overweight permits.

11. Overweight permit required for ANY vehicle EXCEEDING weight limit shown in Item 10. ( ) YES ( ) N/A

12. ALL transport vehicles carrying radwaste shall have a copy of their New York State $\overline{D E C}$ Waste Transport Permit in the vehicle. The transport vehicle shall meet the requirements of the Waste Transport Permit PRIOR TO release from the Protected Area.

NY DEC Waste Transport Permit verified (in vehicle): ( ) YES ( ) NO ( ) N/A

NY DEC Waste Transport Permit \# $\ldots \ldots$

The permit number shall be placarded on both sides AND rear of vehicle. 


\section{ATTACHMENT 8.1 \\ Page 3 of 15 \\ SHIPMENT COMPLIANCE VERIFICATION RECORD \\ PREREQUISITE DOCUMENTATION}

Shipment No:

4. For shipments of radwaste to Richland Facility, Washington:

a. Indian Point 2 possesses a current Site Use Permit from the state of washington.

NO ( ) YES ( ) NA ( )

b. Indian Point 2 possesses a current copy of the Radioactive Materials License for the Richland Facility.

c. PRIOR notification has been provided to the State of Washington AND to the Richland Facility (utilizing the Prior Notification of Shipments of Low Level Solid Waste form, Reference 7.6).

5. For shipments in USNRC Certified OR Licensed Packaging (Casks):

a. Indian Point 2 possesses a controlled, updated Certificate of Compliance (C of $C$ ) for this Cask,

$C$ of $C$ No.

b. Indian Point 2 has provided written seven day advanced notice to the Governor's office of each state to be transited WHEN the criteria of Reference 7.6 are met. (Postal Receipt, letters to Governor).

NO ( ) YES ( ) NA ( )

NO ( ) YES ( ) NA ( )

NO ( ) YES ( ) NA ( )

NO ( ) YES ( ) NA ( )

NO ( ) YES ( ) NA ( )

6. Transport vehicle has been surveyed for radiation AND contamination in accordance with Reference 7.10 PRIOR TO entering the RCA AND meets the contamination AND radiation limits in Reference 7.10 .

ALL prerequisite documentation required above is complete AND in compliance with regulations AND criteria pursuant to Indian Point 2 Shipping Program procedures AND policy. Items of non-compliance have been resolved AND recorded on Compliance Resolution Section of this Attachment. 
1. Completed Bill of Lading
a. Number of packages.
b. Classification of radioactive material.
c. Description of material.
d. Hazardous material DOT identification number.
e. Chemical and physical form.
f. Predominant isotopes.
g. A value.
h. Transport Index. (Non exclusive use only)
i. Total Curies.
j. "Sole Use Vehicle only."
k. Placarded "Radioactive."

2. Completed Radioactive Waste Shipment Certification Form (DHEC-802) for Shipment to Barnwell Facility as per Reference 7.6.

3. Completed Low-Level Radioactive Waste Shipment Certification Form (RHF-31A) for Shipment to Richland Facility as per Reference 7.6.

4. Cask Documentation and Inspection Sheet for applicable cask completed as per Reference 7.13 .

5. For shipments of Pressure Vessels, High Integrity Containers, OR Dewatered Resins to the Barnwell Facility, verify the following as applicable:

a. A dewatering Completion Record has been completed which certifies free-standing water to be:

(1) LESS THAN 0.58 for Carbon Steel Liners. (As per C of $C$ for applicable liner, Check List).

(2) LESS THAN 1.08 of the total volume for High Integrity Containers. (Vendor Documentation) .

(3) LESS THAN $0.5 \%$ for 24 -inch pressure vesse containing activated carbon. (Vendor Documentation).
NO ( ) YES ( ) NA ( )

NO ( ) YES ( ) NA ( )

NO ( ) YES ( ) NA ( )

NO ( ) YES ( ) NA ( )

NO () YES ( ) NA ()

NO ( ) YES ( ) NA ( )

NO ( ) YES ( ) NA ( )

NO ( ) YES ( ) NA ( ) 
CON EDISON

INDIAN POINT STATION

RADWASTE
ATTACHMENT 8.1

Page 5 of 15

SHIPMENT COMPLIANCE VERIFICATION RECORD

RADWASTE SHIPMENT DOCUMENTATION
(4) LESS THAN 0.58 for 24-inch pressure vessels containing resins. (Vendor Documentation).

b. Certification Statement for Disposal of High Integrity Container.

c. Certification Statement for Disposal of FRP. High Integrity Container.

d. Certification Statement for DHEC-HIC-PL-001 (General).

e. Certification Statement for DHEC-HIC-FRP-003 (General).

f. User's check list for HIC completed. (Vendor Documentation).

g. User's check list for FRP HIC completed. (Vendor NO () YES () NA () Documentation).

h. IQC had performed a HIC container inspection AND has documented the inspection for the shipment file.

i. IQC has verified the completion of dewatering activities for container(s) in this shipment AND has provided a copy for the shipment file.

j. For resin, charcoal, on filter cartridges, a copy of the Radionuclide Analytical Data is attached to the shipping papers.

k. For shipments containing chelated wastes, PRIOR NO ( ) YES ( ) NA ( ) approval shall be obtained from Barnwell Regulatory Affairs/Licensing Department.

NOTE:

NO ( ) YES ( ) NA ( )

NO ( ) YES : I NA ( )

NO ( ) YES ( ) NA ( )

NO ( ) YES ( ) NA ( )

NO $($ ) YES ( ) NA ( )

NO ( ) YES ( ) NA ( )

NO ( ) YES ( ) NA ( )

NO ( ) YES ( ) NA ( )

NO ( ) YES ( ) NA ( )
$\mathrm{RW}-\mathrm{SQ}-4.000$

Rev. 9

Shipment No:

ITEMS 1 AND $m$ BELOW APPLY ONLY TO RADIONUCLIDES WITH HALF-LIVES GREATER THAN FIVE YEARS.

1. IF the waste is unsolidified, the activity

NO $(1$ YES ( 1 NA 1$)$

WITHIN a carbon steel vessel does NOT

EXCEED $1 \mathrm{uCi} / \mathrm{cc}$ average over the volume

of the media being shipped. 


\section{ATTACHMENT 8.1 \\ Page 6 of 15 \\ SHIPMENT COMPLIANCE VERIFICATION RECORD RADWASTE SHIPMENT DOCUMENTATION}

Shipment No:

m. For shipments in High Integrity Containers, dewatered resin activity does NOT EXCEED $350 \mathrm{uCi} / \mathrm{cc}$ averaged over the volume of the resin being shipped.

n. For shipments in High Integrity Containers of dewatered resin, fill the containers to NO ( ) YES ( ) NA ( ) a MINIMUM of $85 \%$ full. Filters in a HIC do NOT have to be 858 full.

o. For shipments of solidified waste in carbon steel liners, the final waste product is a uniform monolith with NO free-standing water AND resists penetration with a 1-inch diameter wooden dowel.

p. The Process Control Program checklist for processed waste is completed AND signed, which is applicable to the solidification OR dewatering process for this shipment.

q. IQC has performed a surveillance of a Process Control Program sample solidification AND the solidification of the carbon steel liner. A copy of this surveillance shall be provided to Radwaste for the shipment file.

6. For radwaste shipments, Part 61 Classification Documentation has been completed in accordance with Reference 7.1 OR Reference 7.7 .

7. Radwaste has performed a check of Radman output (Reference 7.1) AND an IQC Inspector has been provided with an opportunity to do a surveillance of Radman operations.

8. For radwaste shipments to and Disposal Manifest (RSDM) has been completed the Radioactive Shipment per Reference 7.8 .

9. For radwaste shipments to Richland Facility, the Radioactive Waste Shipment and Disposal Manifest (RSDM) has been completed per Reference 7.8.

NO ( ) YES ( ) NA ( )

NO ( ) YES ( ) NA ( ) NO () YES ( ) NA ( ) NO ( ) YES ( ) NA ( ) 
RADWASTE

\author{
ATTACHMENT 8.1 \\ Page 7 of 15 \\ SHIPMENT COMPLIANCE VERIFICATION RECORD \\ RADWASTE SHIPMENT DOCUMENTATION
}

Shipment No:

10. For Highway Route Controlled quantities, driver has been provided route instructions from site to destination, including precautions on route modifications.

11. Special handling instructions. (Exclusive Use)
a. Instructions in case of accident/Emergency Response.
b. Tractor-Trailer configuration precautions.
c. Transfer and storage instructions.
NO ( ) $\operatorname{YES}(1)$ NA ( )

NO ( ) YES ( ) NA ( )
NO ( ) YES ( ) NA ( )
NO ( ) YES ( ) NA ( )
NO ( ) YES ( ) NA ( )

ALL shipment documentation required by 49 CFR; 10 CFR Parts 10, 30, 61, 71; Consignee's License; AND Package User Requirements (Certificate of Compliance) have been performed pursuant to Indian Point 2 Shipping Program procedures AND policy. Items of non-compliance have been resolved AND noted in the Compliance Resolution Section of this Attachment. 


\section{ATTACHMENT 8.1 \\ Page 8 of 15 \\ SHIPMENT COMPLIANCE VERIFICATION RECORD \\ NON-RADWASTE SHIPMENT DOCUMENTATION}

Shipment No:

1. Completed Bill of Lading

NO ( ) YES ( ) NA ( )
a. Number of packages.
b. Classification of radioactive material.
c. DOT identification number.
d. Chemical and physical form.
e. Predominant isotopes.
f. $A_{2}$ Value.
g. Transport Index. (Non exclusive use only)
h. Total Curies.

NOTE:

INFORMATION ON BILL OF LADING MAY VARY, DEPENDING ON THE ACTIVITY OF THE MATERIAL AND THE DOT CLASSIFICATION.

2. Consolidated Edison, Indian Point Station

NO ( ) YES ( ) NA ( ) Radioactive Shipment Record. (Reference 7.5).

3. For Exclusive Use shipments, drivers instructions. (Reference 7.5).

NO ( ) YES ( ) NA ( )

4. Vehicle Survey Data Sheets. (Reference 7.4).

NO ( ) YES ( ) NA ( )

5. For Limited Quantity shipments, Excepted

NO ( ) YES ( ) NA ( )

Radioactive Material Form. (Reference 7.9).

6. Container/Package Survey Data Sheet. (Reference 7.4).

NO ( ) YES ( ) NA ( )

ALL shipment documentation has been performed pursuant to 49 CFR AND Indian Point Shipping Program procedures. Items of non-compliance have been resolved AND noted in the Compliance Resolution Section of this Attachment. 
ATTACHMENT 8.1

Page 9 of 15

SHIPMENT COMPLIANCE VERIFICATION RECORD

CONTAINER INSPECTION

Shipment No:

Container No:

1. EACH container of radwaste/radioactive material is properly labeled AND the stability class (radwaste $\underline{\mathrm{ONLY}}$ ) recorded.

2. The proper shipping name of the media being shipped has been determined AND noted on the shipping document AND container.

3. The hazard class of the media being shipped has been determined AND noted on the shipping document AND container.

4. The USDOT shipping classification (LSA, Type A, etc.) has been determined AND noted on the shipping document AND container.

5. This container has been surveyed for radiation AND loose surface contamination, survey results have been reviewed AND attached to the Shipment Record (Reference 7.4).

6. Survey instruments used were calibrated. Serial numbers AND calibration due dates have been recorded on the Container/Package Survey Data Sheet (Reference 7.4).

NO ( ) YES ( ) NA ( )

NO ( ) YES ( ) NA ( ) NO $(1)$ YES ( ) NA ( ) NO ( ) YES ( ) NA ( ) NO ( ) YES ( ) NA ( ) NO $(1)$ YES ( ) NA ( )

This container complies with the requirements of 49 CFR, 10 CFR 71, AND Burial Facility Criteria as specified in References listed in Section 7.0. Discrepancies have been resolved AND recorded on the Compliance Resolution Section of this Attachment. 
CON EDISON

INDIAN POINT STATION

RADWASTE
$\mathrm{RW}-\mathrm{SQ}-4.000$

Rev. 9

ATTACHMENT 8.1

Page 10 of 15

SHIPMENT COMPLIANCE VERIFICATION RECORD

VEHICLE INSPECTION DATA SHEET

SHIPMENT NO:

DATE :

VEHICLE NO:

TRACTOR: TRAILER :

A. Driver Data

1. Name:

2. License No.:

State:

3. Fitness/Training:

SAT ( ) UNSAT ( )

B. Receipt of Vehicle

1. Structural damage to package exterior.

SAT ( ) UNSAT ( ) NA ( )

2. Structural damage to package tie-downs.

SAT ( ) UNSAT ( ) NA. ( )

3. Missing $\mathrm{OR}$ loose bolts in tie-down SAT ( ) UNSAT ( ) NA ( ) assembly.

4. ALL lid/cover hold-down hardware in place.

SAT ( ) UNSAT ( ) NA ( )

5. General inspection of vehicle, for damage

SAT ( ) UNSAT ( ) NA ( )

OR broken lights, flat tire, obvious frame cracks.

6. Verify vehicle registration is current.

SAT ( ) UNSAT ( ) NA ( )

\section{Vehicle Safety}

1. Tire Tread:
a. NO recaps on front
b. $\overline{4 / 32}$ on front AND spare
c. 2/32 on ALL others
d. Tires properly inflated

SAT ()
UNSAT ( )
SAT () UNSAT ()
SAT () UNSAT ()

2. Brakes:
a. Service
b. Connections to trailer
c. Parking
d. Air pressure (MINIMUM $100 \mathrm{psi}$ )

SAT ( ) UNSAT ( ) SAT () UNSAT ( )

3. Parking Brake:

a. Parking brake operable

b. Set during loading operations 
CON EDISON

INDIAN POINT STATION

RADWASTE
ATTACHMENT 8,1

Page 11 of 15

SHIPMENT COMPLIANCE VERIFICATION RECORD VEHICLE INSPECTION DATA SHEET
$R W-S Q-4.000$

Rev. 9

DATE :

SHIPMENT NO:

SAT ( )
SATSAT ( )
SAT ( ) UNSAT ( )
UNSAT ( !
SAT ( ) UNSAT ( )
SAT ( ) UNSAT ( )

EQUAL TO $10 \mathrm{BC}$ ).

9. Windshield wipers

10. Rear-view mirrors

11. Trailer/tractor coupling (driver shall apply trailer brakes AND load test the fifth wheel pin).

12. Trailer/vehicle frame crack inspection.

13. Cask AND external tie-down system.

14. All non-fixed lifting devices are removed.

15. Load has been properly placed AND bracing is installed.

16. Evidence of driver daily log.

D. Vehicle Final Checks

1. Placarding is placed on front, back, AND both sides of trailer AND in front of the tractor (verify that placarding complies with the Bill of Lading description).

NOTE :

PLACARDING THE FRONT OF THE TRAILER IS OPTIONAL.

2. Emergency Kit provisions checked (Rad. SAT ( ) UNSAT () rope, Anti-C's, signs, etc.)

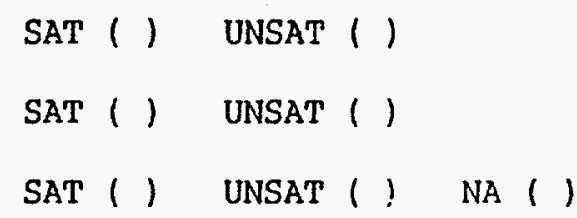


RADWASTE

\author{
ATTACHMENT 8.1 \\ Page 12 of 15 \\ SHIPMENT COMPLIANCE VERIFICATION RECORD \\ VEHICLE INSPECTION DATA SHEET
}

SHIPMENT NO:

DATE :

3. Vehicle load inspection completed AND vehicle doors secured with locking device (seal).

4. ALL vehicle external loose contamination surveys have been completed AND are WITHIN the Administrative Guidelines specified in Addendum 9.1. ALL vehicle external radiation surveys have been completed and are WITHIN the USNRC/USDOT limits AND Administrative Guidelines, as specified in Addendum 9.1.

5. Photographs made of ALL sides of vehicle and placed in the Shipment Record.

6. Driver provided copies of shipping papers, waste manifest, Bill of Lading, AND other applicable shipping documents.
YES ( ) NO ( ) NA ( )

$\operatorname{YES}(1)$ NO ( ) NA ( )

YES ( ) NO ( ) NA ( )

The vehicle is certified to be in compliance with applicable USNRC/USDOT requirements for shipping radioactive materials. Compliance has been verified through document inspection AND field checks. Items of non-compliance were resolved as indicated on the Compliance Resolution Section of this Attachment. 
ATTACHMENT 8.1

Page 13 of 15

SHIPMENT COMPLIANCE VERIFICATION RECORD

COMPLIANCE RESOLUTION AND COMMENTS

SHIPMENT NO:

DATE :

A. Items of Non-Compliance - Resolution: (IF none, mark "NONE" AND sign.)

B. Comments: 
CON EDISON

INDIAN POINT STATION

ATTACHMENT 8.1

$R W-S Q-4.000$

RADWASTE

Page 14 of 15

Rev. 9

INDIAN POINT UNIT 2 IQC NOTIFICATION ACKNOWLEDGMENT RECORD

Container ID No.

1. Operation AND Dewatering of Vendor Demineralization System

1.1 The Radwaste Supervisor has notified an IQC Inspector of the arrival on site of HIC/FRP to be used for waste processing.

IQC Inspector

1.2 The Radwaste Supervisor/Vendor operator has notified an IQC Inspector of the intent to begin dewatering operations.

$\frac{1}{\text { IQC Inspector }}$

2. RW-SQ-4.011, Radman Program Operation

2.1 The Radwaste Supervisor has notified an IQC Inspector of the intention to perform hand/computer-based calculations to verify the Radman Program.

$\frac{1}{\text { IQC Inspector }}$

3. RW-SQ-4.007, Process Control Program

3.1 The Sr. Radwaste Supervisor has reviewed the vendor's Process Control Program AND has completed the Checklist for Vendor Process Control Program (Attachment 8.1 of RW-SQ-4.007).

IQC Inspector


4. RW-SQ-4.201, Replacement and Dewatering of Filters

4.1 The Radwaste Supervisor has notified an IQC Inspector to afford them the opportunity to perform a receipt inspection on ANY HIC to be dewatered.

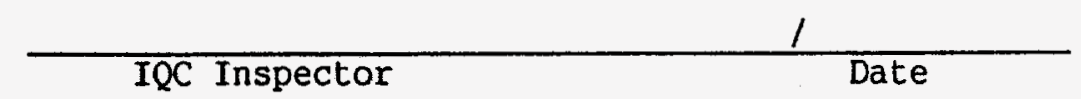

4.2 The Radwaste Supervisor has notified an IQC Inspector to afford them the opportunity to perform a dewatering surveillance.

$\frac{1}{\text { IQC Inspector }}$


1. Shipment Number:

Date:

2. Consignor:

Telephone:

3. Shipment Description:

4. Type of Shipment:

RADWASTE<smiles>C1I2CI12</smiles>

NON-RADWASTE

5. Mode of Transport:

HIGHWAY

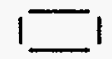

RAIL

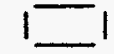

6. Carrier Name and Address:

Telephone:

7. Exclusive Use:

$$
\text { YES }
$$

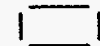

NO

8. Total Number Containers Shipped:

Package Type:

Container Type:

NO ( ) YES ( ) NA ( )

9. Completed Bill of Lading

a. Number of packages

b. Classification of radioactive material

c. DOT identification number

d. Chemical and physical form

e. Predominant isotopes

f. A, Value

g. Transport Index (Non exclusive use only)

h. Total Curies 
CON EDISON

INDIAN POINT STATION

RADWASTE
$\mathrm{RW}-\mathrm{SQ}-4.000$

Rev. 9

ATTACHMENT 8.2

Page 2 of 3

INCOMING SHIPMENT VERIFICATION RECORD

Shipment No:

NOTE:

INFORMATION ON BILL OF LADING MAY VARY, DEPENDING ON THE ACTIVITY OF THE MATERIAL AND THE DOT CLASSIFICATION.

10. Consignor's Radioactive Shipment Record

11. For Exclusive use shipments, drivers instructions

12. Vehicle Survey Data Sheets

13. For Limited Quantity shipments, Excepted Radioactive Material Form

14. Container/Package Survey Data Sheet

15. Incoming shipment contains the types of isotopes and quantities of material allowed by the station radioactive material license

16. Incoming shipment vehicle and package radiative and contamination limits fall within the limits in Addendum 8.1 of Reference 7.10

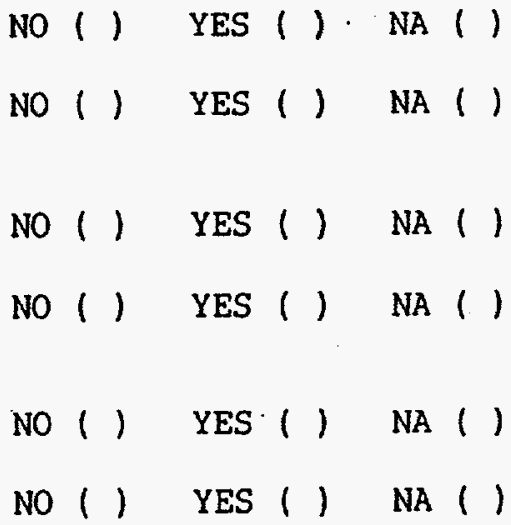

NO ( ) YES ( ) NA ( ) 
CON EDISON

INDIAN POINT STATION

RADWASTE
$\mathrm{RW}-\mathrm{SQ}-4.000$

Rev. 9

\section{ATTACHMENT 8.2 \\ Page 3 of 3}

\section{INCOMING SHIPMENT VERIFICATION RECORD VEHICLE INSPECTION DATA SHEET}

Shipment No:

17. Receipt of Vehicle

1. Structural damage to package exterior.

SAT ( ) UNSAT ( $)^{\circ}$ NA ( )

2. Structural damage to package tie-downs.

SAT ( ) UNSAT ( ) NA ( )

3. Missing $\mathrm{OR}$ loose bolts in tie-down

SAT ( ) UNSAT ( ) NA ( ) assembly.

4. ALL lid/cover hold-down hardware in place.

SAT ( ) UNSAT ( ) NA ( )

5. General inspection of vehicle, for damaged OR broken lights, flat tire, obvious frame SAT ( ) UNSAT ( ) NA ( ) cracks.

6. Verify vehicle registration is current.

SAT ( ) UNSAT ( ) NA ( )

The incoming shipment meets the standards pursuant to $49 \mathrm{CFR}$ and Indian Point shipping program procedures. 
CON EDISON

INDIAN POINT STATION

RADWASTE
ADDENDUM 9.1

Page 1 of 3
$\mathrm{RW}-\mathrm{SQ}-4.000$

Rev. 9

RADIOACTIVE MATERIALS PACKAGES

RADIATION AND CONTAMINATION LEVEL LIMITATIONS

\section{USNRC/USDOT LIMITS}

\section{Radiation Levels}

Radiation Level (dose rate) at $\underline{A N Y}$ point on the external surface of ANY package of R.A.M. maY NOT EXCEED:

A. 200 millirem per hour.

B. 10 millirem per hour at one meter* (Transport Index may NOT EXCEED 10).

UNLESS the packages are transported in an "Exclusive Use" closed transport vehicle (aircraft prohibited) - THEN the MAXIMUM radiation levels may be:

A. 1000 millirem per hour on the accessible external package surface. (Closed van ONLY).

B. 200 millirem per hour at ANY point on the external surface of the vehicle.***

C. 10 millirem per hour at two meters* from external surface of the vehicle.

D. 2 millirem per hour in ANY position of the vehicle which is occupied by a person. ${ }^{\star \star \star \star \star}$

$\star \quad 3.3$ feet

* 6.6 feet

*** The external surface includes the top AND underside of the vehicle. For a flatbed, external surface means at ANY point on the vertical planes projected from outer edge of the truck AND on the upper surface of the load oR enclosure (IF used).

$\star \star \star \star$ Excluding the top AND underside of the vehicle.

****Does NOT apply to private carriers with dosimetry who operate under a state $\underline{\text { OR }}$ Federally regulated Radiation Protection Program. 
RADIOACTIVE MATERIALS PACKAGES

RADIATION AND CONTAMINATION LEVEL LIMITATIONS

\section{CON EDISON SITE ADMINISTRATIVE GUIDELINES}

\section{Radiation Levels}

Radiation Level (dose rate) at ANY point on the external surface of ANY package of R.A.M. may NOT EXCEED the following Site Administrative Guidelines without permission from the Radwaste Supervisor.

A. 160 millirem per hour.

B. 8 millirem per hour at one meter (Transport Index may NOT EXCEED 10).

UNLESS the packages are transported in an "Exclusive Use" closed transport vehicle (aircraft prohibited) - THEN the MAXIMUM Administrative radiation levels may be:
A. 800 millirem per hour on the accessible external package surface. (Closed van ONLY).
B. 160 millirem per hour at ANY point on the external surface of the vehicle.**
C. 8 millirem per hour at two meters * from external surface of the vehicle. $* \star \star \star$
D. 1.5 millirem per hour in ANY position of the vehicle which is occupied by a person. ${ }^{\star \star \star \star \star}$

NOTE :

SURVEYS SHALL BE CONDUCTED A MINIMUM OF TWO TIMES IF THESE LEVELS ARE EXCEEDED. INSTRUMENTS USED SHOULD BE COMPATIBLE WITH THE DISPOSAL, REPROCESSING OR OTHER LICENSEE RECEIVING THE WASTE/MATERIAL.

- $\quad 3.3 \mathrm{feet}$

$\star * \quad 6.6$ feet

** The external surface includes the top AND underside of the vehicle. For a flatbed, external surface means at ANY point on the vertical planes projected from outer edge of the truck AND on the upper surface of the load OR enclosure (IF used).

$\star \star \star *$ Excluding the top AND underside of the vehicle.

$\star \star \star * *$ Does NOT apply to private carriers with dosimetry who operate under a state $\underline{O R}$ Federally regulated Radiation Protection Program. 
CON EDISON

INDIAN POINT STATION

RADWASTE
ADDENDUM 9.1

$\mathrm{RW}-\mathrm{SQ}-4.000$

Rev. 9

RADIOACTIVE MATERIALS PACKAGES RADIATION AND CONTAMINATION LEVEL LIMITATIONS

II. Con Edison Site Administrative Guidelines (Continued)

Contamination Levels

A. WHEN shipped in a shielded cask, $\mathrm{ALL}_{2}$ external surfaces of ANY contajner shal1 be LESS THAN $40,000 \mathrm{dpm} / 100 \mathrm{~cm}^{2}$ beta-ganma AND $220 \mathrm{dpm} / 100 \mathrm{~cm}^{2}$ alpha.

B. WHEN shipped by OTHER THAN a shielded cask, ALL external surfaces of ANY container shall be LESS THAN $1,000 \mathrm{dpm} / 100 \mathrm{~cm}$ beta-gamma AND 20 $\overline{\mathrm{dpm}} / 100 \mathrm{~cm}^{2}$ alpha. 
CON EDISON

INDIAN POINT STATION

TECHNICAL SERVICES

(1) GENERATOR NAME

FACILTY

RDDRESS

CITY STATE ZIP

CONTACT PHONE( 1

EMERGENCY RESPONSE CONTACT $\because \ldots \ldots, \ldots \ldots$

(2)

WAC

Attachment 4

TS-SQ-4.002

Rev. 5

\section{ANIFEST}

BARNWELL WHO IL ............ Operaled by CHEM-NUCLEAR SYSTEMS, INC PO Box 726, Barmwell, South Carolina 29812

AADIOACTIVE SHIPMENT MANIFEST FORM

(3A) RADIOACTIVE WASTE TRANSPORTATION PERMIT NO.

\section{(4) USE THIS NUMBER ON
ALL CONTINUATION PAGES}

B) NUMBER OF GENERATORS

SHIPMENT TOTALS

\begin{tabular}{|c|c|c|c|c|}
\hline \multicolumn{2}{|c|}{$\begin{array}{l}\text { 16) TOTAL FOA } \\
\text { EACH CUSS }\end{array}$} & $\begin{array}{l}\text { PAOPER SHIPPING NAME \& HAZARD CLASS } \\
\text { (PEA A9 GFA 172 101) }\end{array}$ & $\begin{array}{l}\text { M.D. } \\
\text { NUIABEa }\end{array}$ & Peponable \\
\hline NOO OF & WEIGHI & $\because \therefore \ldots$ & & \\
\hline & & 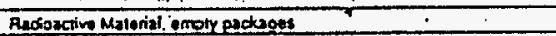 & UN2000 & \\
\hline & 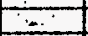 & 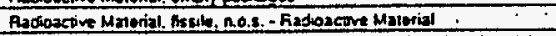 & unzeg1日 & \\
\hline & & 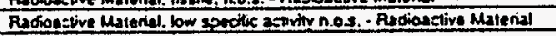 & Uw12912 & \\
\hline$\because$ & $\because$ & 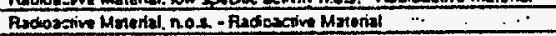 & UN2982:- & \\
\hline & $\vdots$ & 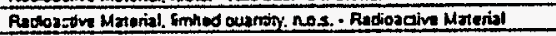 & UNz910. & \\
\hline & $\therefore$ & 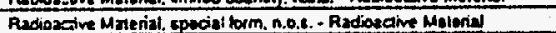 & Unz2074: & \\
\hline & & 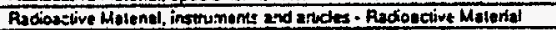 & UNखgin & \\
\hline & & Oner (Sosoly) & & \\
\hline
\end{tabular}

is

(13) PHYSICAL

(12) WASTE DESCRIPTION

(168) ( I Yes ( I No This waste(s) must be disposed in South Carolina Deparment of Heallh and

(17) ( I Yes ( ) NO THIS VEHICLE IS CONSIGNED EXCLUSIVE USE. LOADING AND UNLOADING MUST BE ACCOIMPLISHED BY CONSIGNOR OR CONSIGNEE OR HIS DESIGNATED AGENT.

(18) MMPOATANT: This is to centily that the above named traterials are properly classified. described. packaged.

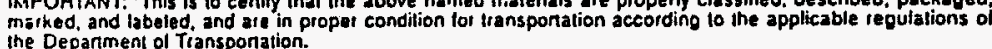

Signature

Company _____ Dale

\begin{tabular}{|c|c|c|c|c|c|c|c|c|c|c|}
\hline \multicolumn{3}{|l|}{ (7) } & \multicolumn{5}{|c|}{ SHIPMENT TOTALS } & \multicolumn{3}{|c|}{ TOTAL SNM } \\
\hline \multirow{4}{*}{$\begin{array}{c}\text { Disposas } \\
\text { volume } \\
\text { (th. i) }\end{array}$} & \multirow{4}{*}{$\begin{array}{c}\text { Tolal } \\
\text { No.of } \\
\text { Packages }\end{array}$} & \multicolumn{5}{|c|}{$\begin{array}{l}\text { ACTIVITY (10CFA20.311) } \\
\text { Millicuries }\end{array}$} & \multirow{3}{*}{$\begin{array}{l}\text { Source } \\
\text { (Pounds) }\end{array}$} & isolope & Giams & 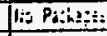 \\
\hline & & & & & & & & U.233 & & \\
\hline & & isolopes & Tritium & C.14 & TC-99 & 1.129 & & u.235 & & \\
\hline & & & & & & & & Tolal & & \\
\hline
\end{tabular}

MINIMUIN WASTE

(14)

SOLIOIFICATION

CHEMICAL

NAME AND \% OF

(16 A)

(19) 'Cenilicalion is hereby made to the South Carolina Depantmenl of Heath and Environmental Constol that this shipment of lox'le:el

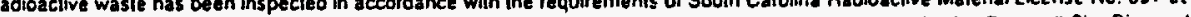
amended, and the Nuclear Regulalony Commission's License No. 12-13536-01 as amended, and the etikecive Earnweit Silt Dispasal Criteria within 48 hours prior to shipment, and turher centilication is made that the inspection fevealed no iltems of non-compliarse with all applicable laws, cules and regulations. Signature.

DISPOSAL SITE COPY

Tille and Organization

Telephone No. 1 (1-90)

SEE WSTAUCTIONS ON RE NE RSE SIDE

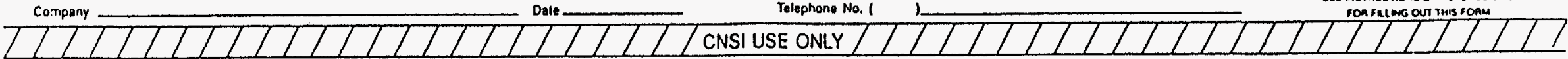

$\square$ This malerial meels all license requirements.

$\square$ This material was disposed of in accordance wilh hicense.

Crane $\square \quad$ Forklill $\square$

Shietded $\square \quad \begin{aligned} & \text { Pe:sonnel } \\ & \text { Bartier }\end{aligned}$

$\square$ Discrepancy.

Dale

Overpack $S N$

Overpack Lid SN

Orhor

Authorized Signalure
Arrival Dale

Date,Time Buried

Tench

Waste Class Code

Trench No. Location Code

Waste Class Code

Personnel Exposure 
CON EDISON

INDIAN POINT STATION

TECHNICAL SERVICES
ATTACHMENT 8.1

Page 2 of 2

CNSI RADIOACTIVE SHIPMENT MANIFEST
TS $-S Q-4.002$

Rev. 5

BARNWELL WASTE MANAGEMENT FACILITY

Operated by: CHEM-NUCLEAR SYSTEMS, INC.

GENERATOR NAME

CONTINUATION SHEET

USE THIS NUMBEA ON

SHIPUENTIO MUUBER

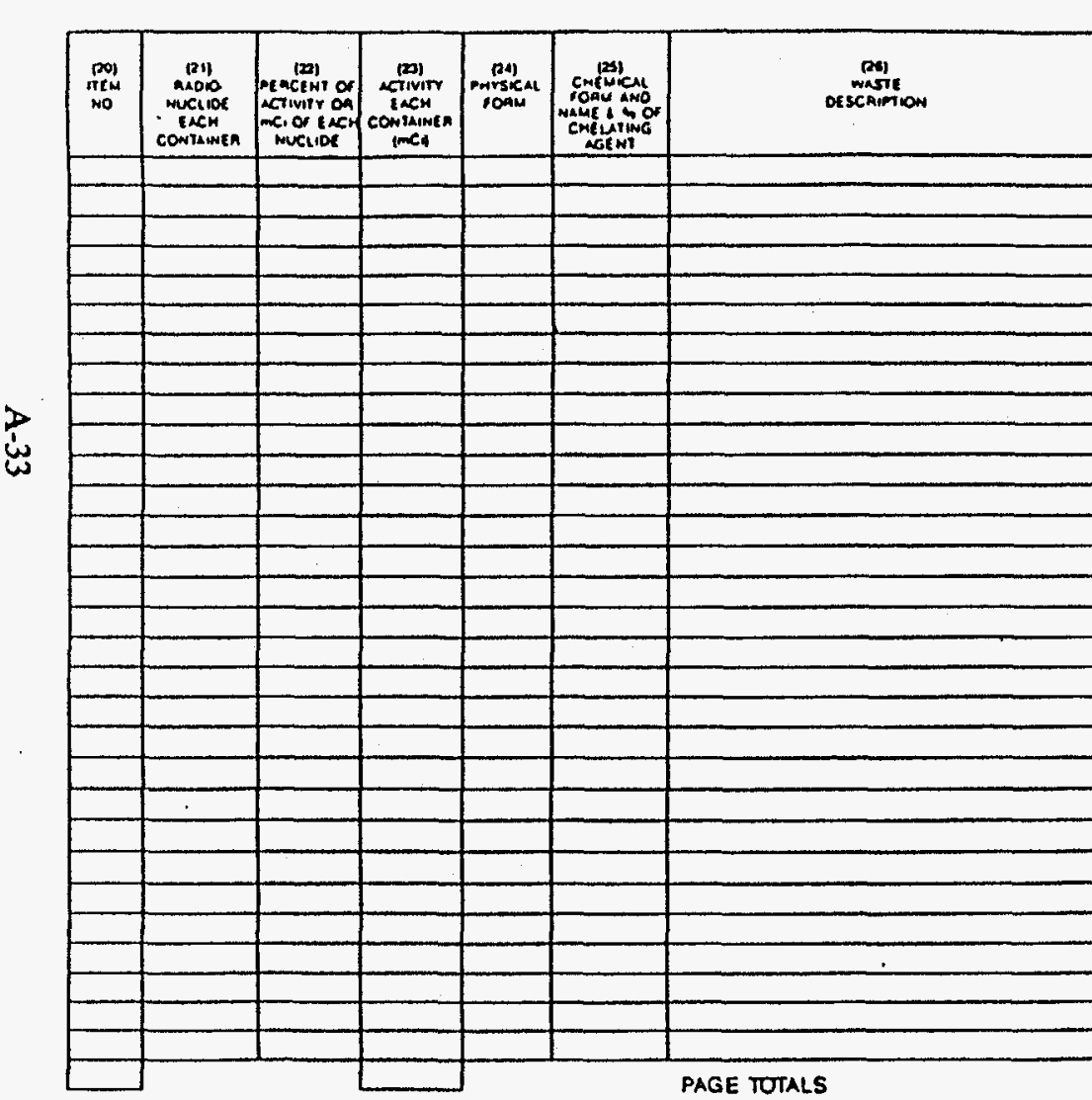

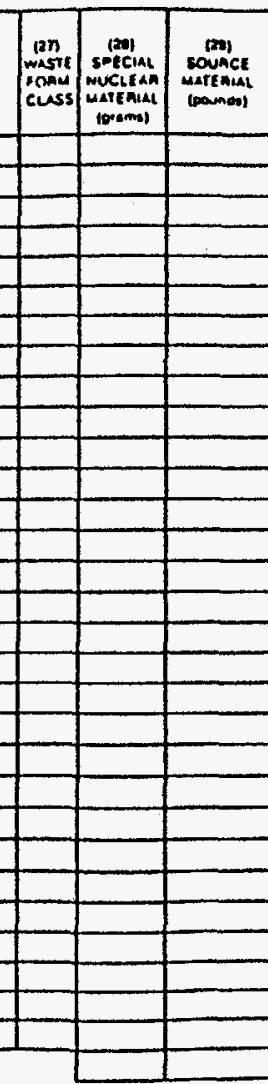

ALL CONTINUATION PAGES

PAGE $=$ OF -

\begin{tabular}{|c|c|c|c|c|c|c|c|}
\hline 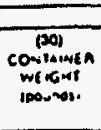 & 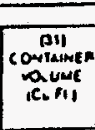 & 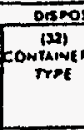 & 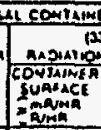 & 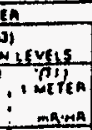 & 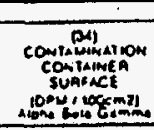 & $\begin{array}{l}\text { iss } \\
\text { issuf } \\
\text { Giass }\end{array}$ & 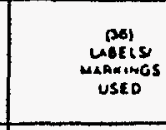 \\
\hline & & & & & & & tonounen- \\
\hline & & & & & $!$ & & 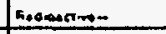 \\
\hline & & & & & $\therefore$ & & s.osenco- \\
\hline & & & & & $\vdots$ & & a.sosen- \\
\hline & & & & & $\therefore$ & & Fo.000000- \\
\hline & & & & & & & noosenom=- \\
\hline & & & & & $i$ & & A.easono- \\
\hline & & & & & $\therefore$ & & a.sosecine- \\
\hline & & & & & $i$ & & $0.00000=$ \\
\hline & & & & & $\div$ & & anoconos- \\
\hline & & & & & & & $\sigma_{0.0000000}$ \\
\hline & & & & & $\dot{0}$ & & foosecono- \\
\hline & & & & & $\div$ & & no. \\
\hline & & & & & $\therefore$ & & a.0.04no- \\
\hline & & & & & $\dot{-}$ & & a.togen- \\
\hline & & & & & $\vdots$ & & Rosengen- \\
\hline & & & & & $\vdots$ & & a oesosonos- \\
\hline & & & & & 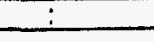 & & nososono- \\
\hline & & & & & & & Aotosano- \\
\hline & & & & & & & noocam- \\
\hline & & & & & & & a.ososenco \\
\hline & & & & & & & noosenan- \\
\hline & & & & & & & nosomane \\
\hline & & & & & & & 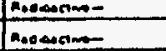 \\
\hline & & & & & & & $0,0000000-$ \\
\hline & & & & & & & 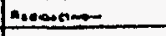 \\
\hline & & & & & & & A.sonsone \\
\hline & & & & & & & 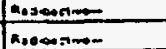 \\
\hline & & & & & & & \\
\hline
\end{tabular}


CON EDISON

INDIAN POINT STATION

TECHNICAI SERVICES
ATTACHMENT 8.2

Page 1 of 2
TS-SO-4.002

Rev. 5

\section{USEI RADIOACTIVE SHIPMENT MANIFEST}
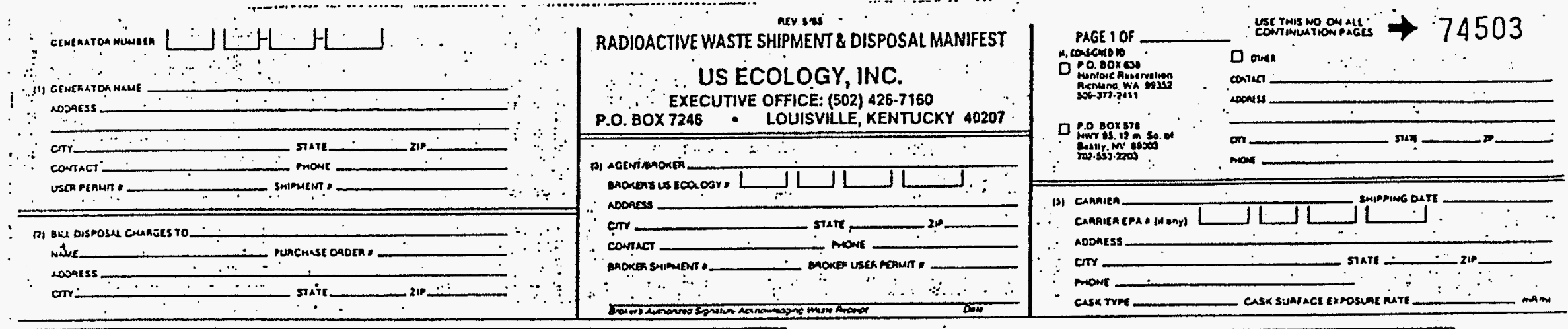

\begin{tabular}{|c|c|c|c|}
\hline \multicolumn{2}{|c|}{ VOTN FOA LRCHCUSS } & \multirow{2}{*}{ 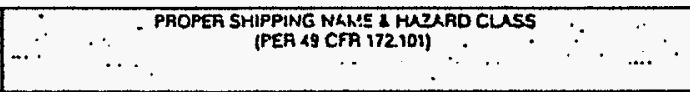 } & \\
\hline DACKAGES & Titiam & & \\
\hline & & Irioselve Milerial emply packajes & $=$ \\
\hline 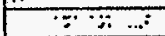 & $\bar{*}=$ & 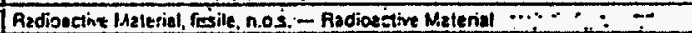 & 29 \\
\hline 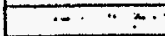 & $\because$ & 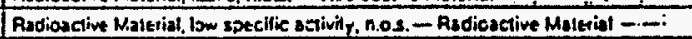 & 12312 \\
\hline 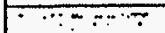 & $\because=2$ & Fodioneline Malerial nos: - Rastionctive Material & UN2989 \\
\hline$\because \therefore \quad \therefore$ & $-\because \cdot$ & Gouctive Malerial " & 2910 \\
\hline 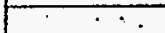 & 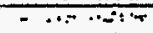 & ve Material - & 0 \\
\hline$\because \because$ & $\because=$ & ilces - Radioactive Malerial $=\because \div \cdots$ & 2211 \\
\hline$\therefore$ & $\therefore \ldots$ & 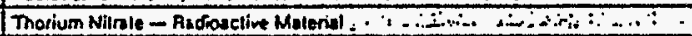 & \\
\hline$\because \cdots$ & & dine Halerial ....: & N29180 \\
\hline$\because \ldots$ & 7 & 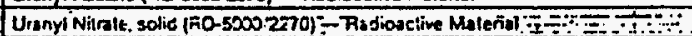 & UNE299 \\
\hline
\end{tabular}

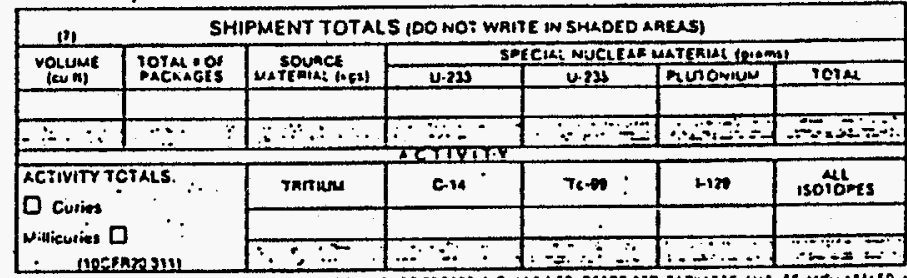

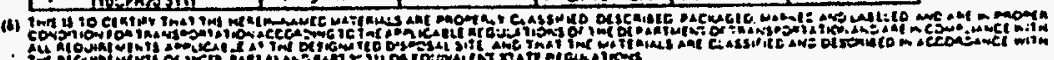

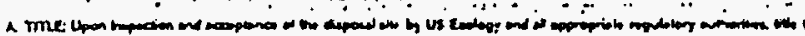

A mest moouct a

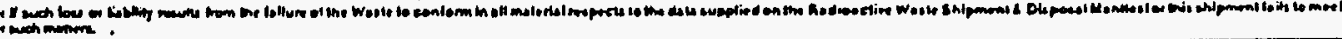

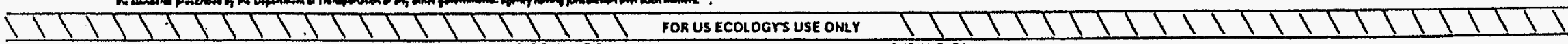

\begin{tabular}{|c|c|c|c|}
\hline $\begin{array}{l}\text { MPE OF } \\
\text { COMAINE }\end{array}$ & 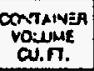 & Pof & 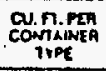 \\
\hline \multicolumn{4}{|l|}{ 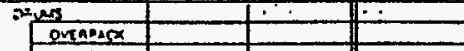 } \\
\hline & 18 & & \\
\hline & $\frac{.11}{610}$ & & \\
\hline 3 & & & \\
\hline \multicolumn{4}{|l|}{$\frac{10126}{253}$} \\
\hline \multicolumn{4}{|l|}{ 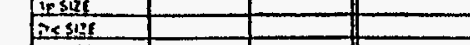 } \\
\hline \multicolumn{4}{|l|}{ resing } \\
\hline \multicolumn{4}{|l|}{ 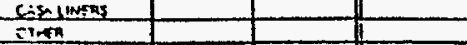 } \\
\hline cines & & &. \\
\hline S-9ing & & & \\
\hline
\end{tabular}

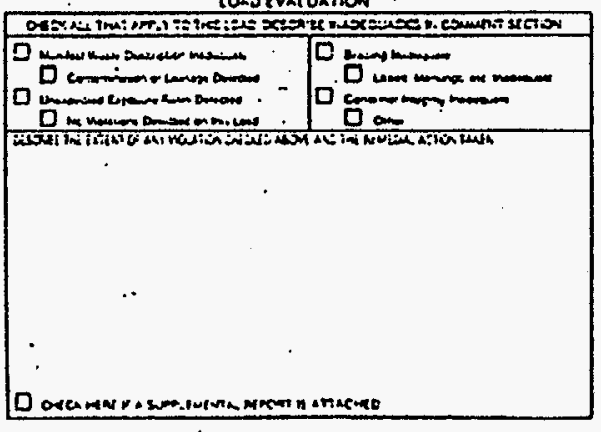

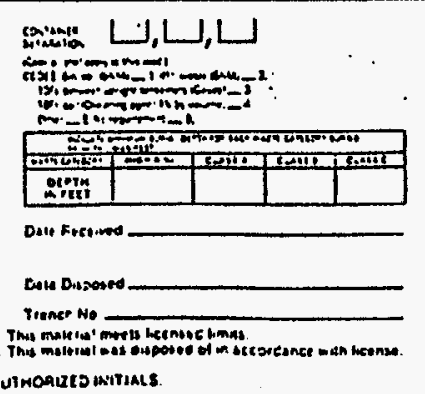

sainin

$=0$

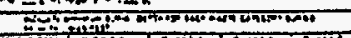

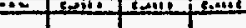

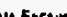

turmanuis anitials.

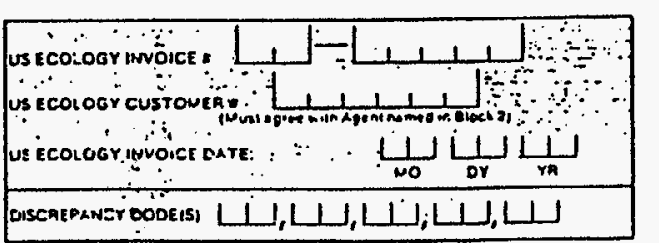

BATES \# 


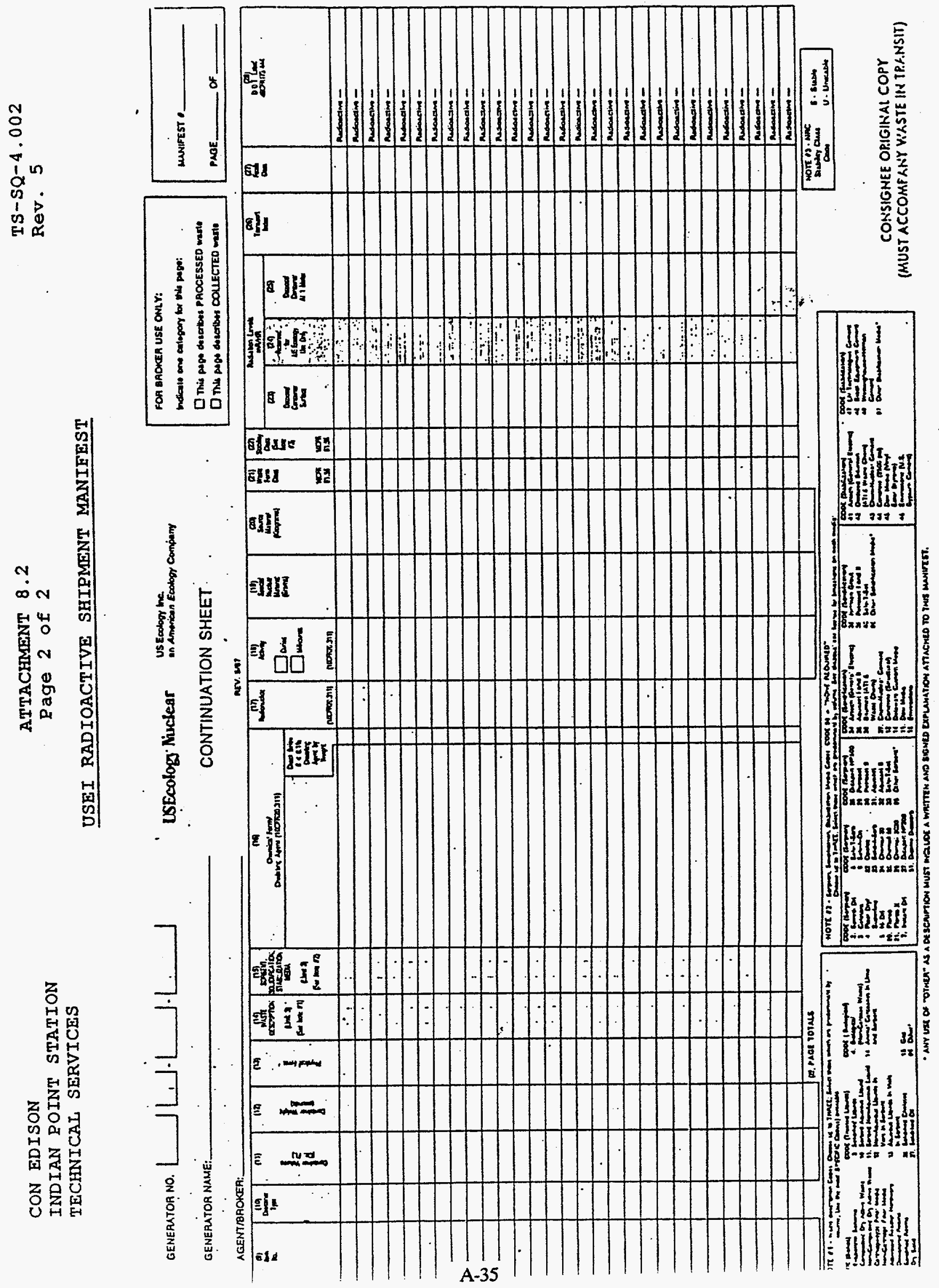


1. Waste description:

2. Volumes: (a) Container volume $\left(\mathrm{Et} \mathrm{t}^{3}\right.$ ) (b) Waste volume $\left(\mathrm{cm}^{3}\right)$

3. Container type:

4. Radiation levels: MAXIMUM Dose Rate of Disposal Container at one (1) Foot:

5. Total curie content:

6. Radionuclide concentrations:

\begin{tabular}{lccc} 
Each Radionuclide & $\begin{array}{c}\text { Total Activity Each Transuranic } \\
\text { Concentration } \\
\text { Radionuclides }\end{array}$ (Microcuries/cc) & $\begin{array}{c}\text { Each } \\
\text { Radionuclide }\end{array}$ (Nanocuries/gm) \\
\hline
\end{tabular}

Total Concentration of ALL Transuranics

$(3723 \mathrm{~g})$ 
CON EDISON

INDIAN POINT STATION

TECHNICAL SERVICES
TS-SQ-4.002

Rev. 5

ATTACHMENT 8.3

Page 2 of 2

CLASS "C" WASTE CLASSIEICATION RECORD

Generator Name

7. Waste Classification Methods:

- (a) Describe method:

\section{SIGNATUPBE:}

TITLE :

IF a vendor is used, also include vendor's name, primary contact, AND telephone number.

(3723g)
DATE :

COMPANY :
Shipment ID Number 
Appendix B

Radioactive Material Licenses for Low-Level Radioactive Waste Disposal Facilities 
B-2 


\section{Appendix B}

\section{Radioactive Material Licenses for Low-Level Radioactive Waste Disposal Facilities}

The following licenses are included in Appendix B:

- $\quad$ Chem-Nuclear Systems, Inc., Barnwell, SC (Amendment No. 45)

- U.S. Ecology, Inc., Beatty, NV (Amendment Nos. 13 and 14)

- U.S. Ecology, Inc., Richland, WA (Amendment No. 18)

- $\quad$ Envirocare of Utah, Inc., Clive, UT (Amendment No. 12). 
B-4 


\section{CHEM-NUCLEAR SYSTEMS, INC.}

REASON FOR CHANGE:

CHANGES MADE TO UPDATE CRITERIA TO REFLECT CURRENT

LICENSE AMENDHENT

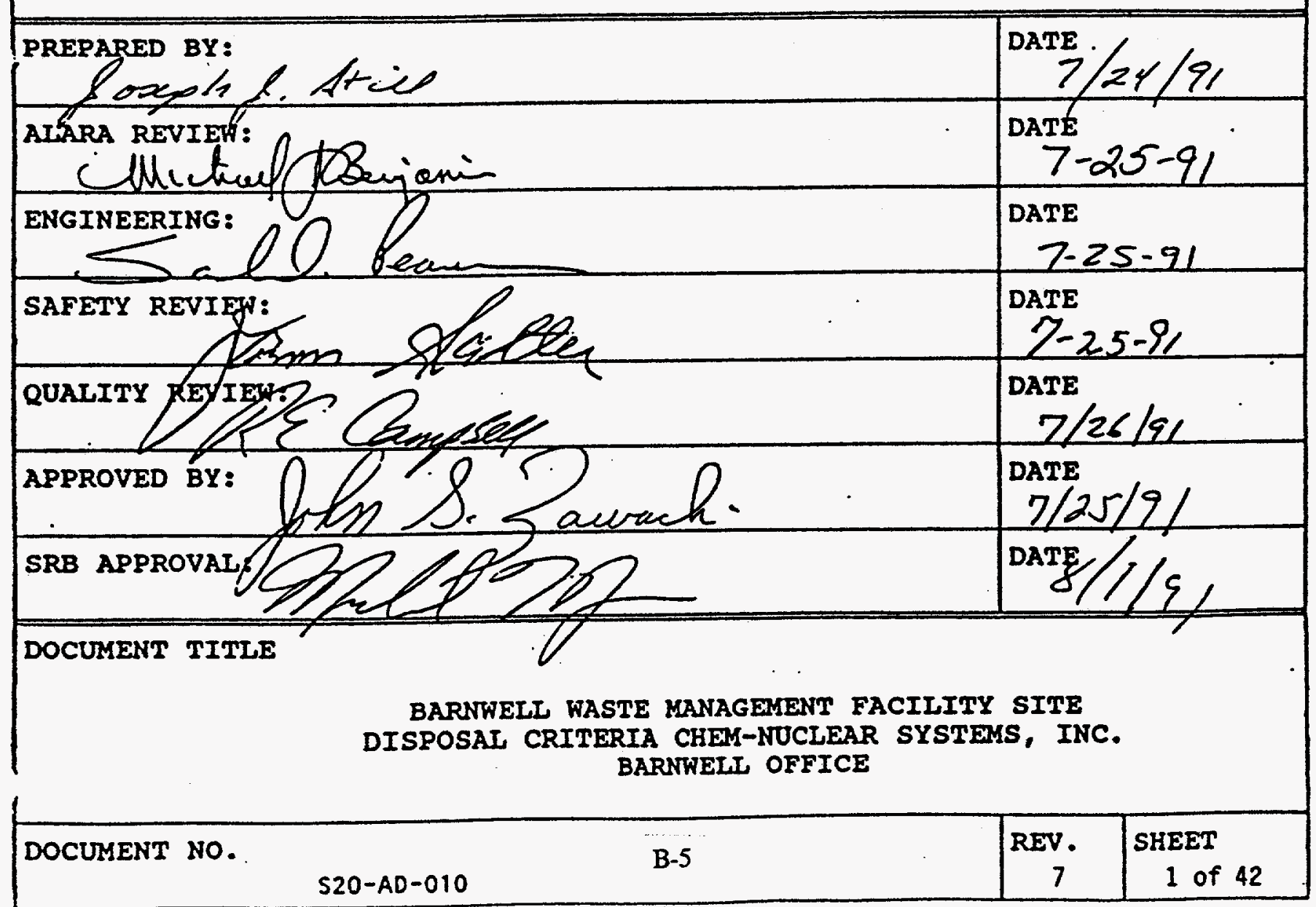




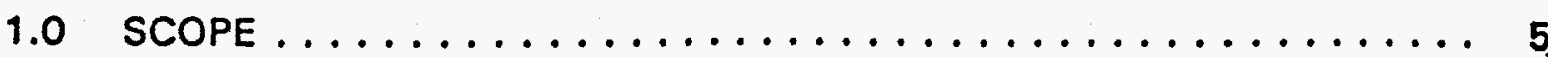

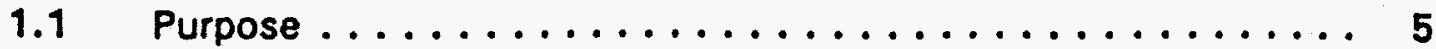

1.2 Applicability ..................... 5

2.0 REFERENCES $\ldots \ldots \ldots \ldots \ldots \ldots \ldots \ldots \ldots \ldots \ldots \ldots \ldots$

3.0 GENERAL INFORMATION $\ldots \ldots \ldots \ldots \ldots \ldots \ldots \ldots \ldots \ldots$

3.1 CNSI Telephone Numbers $\ldots \ldots \ldots \ldots \ldots \ldots \ldots \ldots \ldots 6$

3.2 Normal Hours of Operation . . . . . . . . . . . . . 6

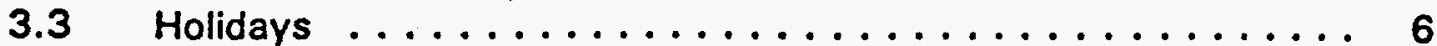

3.4 Pre-Shipment requirements ............... 6

3.5 Shipment Prior Notification ............... 8

3.6 Shipment Documentation ................ 8

3.7 Offloading Schedule $\ldots \ldots \ldots \ldots \ldots \ldots \ldots \ldots \ldots$

3.8 Driver Check-In Procedure ................ 10

3.9 Delays ......................... 10

3.10 Retrievability of Disposed Material .............. 10

3.11 Equipment Storage ................... 10

4.0 WASTE SHIPMENT SCHEDULING PLAN (WSSP) $\ldots \ldots \ldots \ldots \ldots 11$

$4.1 \quad$ General $\ldots \ldots \ldots \ldots \ldots \ldots \ldots \ldots \ldots \ldots \ldots \ldots \ldots 11$

4.2 Shipment Scheduling ................... 11

5.0 PRIOR NOTIFICATION PLAN (PNP) $\ldots \ldots \ldots \ldots \ldots \ldots \ldots \ldots$

5.1 General ........................ 11

5.2 Instructions $\ldots \ldots \ldots \ldots \ldots \ldots \ldots \ldots \ldots \ldots \ldots \ldots \ldots$

5.3 PNP Notifications $\ldots \ldots \ldots \ldots \ldots \ldots \ldots \ldots \ldots \ldots \ldots \ldots$

6.0 RADIOACTIVE SHIPMENT MANIFEST (RSM) FORMS (CNS-201) . . . 12

6.1 General ......................... 12

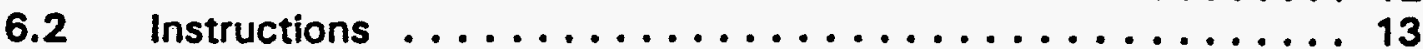

6.3 Special Considerations ................... 13

6.4 Individual Packages Containing Multiple Waste Forms ...... 14

7.0 VOlUME MEASUREMENT CRITERIA .............. 15

8.0 WASTE CLASSIFICATION AND PACKAGING $\ldots \ldots \ldots \ldots \ldots \ldots 16$

\begin{tabular}{|l|l|l|l|}
\hline DOCUMENT & B-6 & SHEVT & \\
& S20-AD-010 & 7 & 2 \\
\hline
\end{tabular}




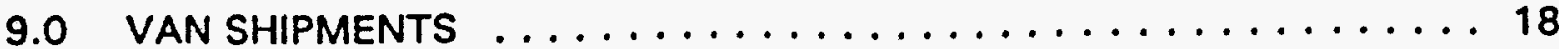

9.1 Drums .............................. 18

9.2 Packages Weighing Less Than 8,000 Pounds ICNSI Forklift

Capacityl ........................... 19

9.3 Packages Weighing More Than 8,000 Pounds . . . . . . . . . . . 19

9.4 Mixed Shipments (Drums, Boxes, Liners, etc., Containing

Class A, B and C Waste) .................. 20

10.0 FLATBED TRAILER SHIPMENTS . . . . . . . . . . . . . . . . . . 21

11.0 CASK SHIPMENTS ......................... 21

12.0 CONTAMINATION LIMITS OF PACKAGENEHICLE . . . . . . . . . . 23

12.1 General .......................... 23

12.2 Floor Covering .......................... 24

12.3 Decontamination Prior to Release ... . . . . . . . . . . . . . 24

12.4 Contamination Release Limits for Vehicles Exiting the Barnwell

Site .......................... 24

13.0 SPECIAL CATEGORIES ....................... 25

13.1 Biological Material . . . . . . . . . . . . . . . 25

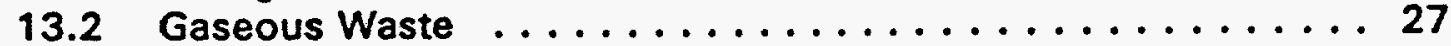

13.3 Sealed Sources or Special Form Radioactive Materials . . . . . . 28

13.4 Liquid Radioactive Waste .................... 28

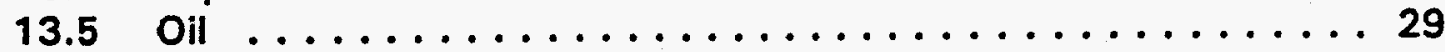

13.6 Pyrophoric Materials or Flammable Solids . . . . . . . . . . . . 29

13.7 Special Nuclear Material (SNM) (U-233 and U-235 Only) . . . . 29

13.8 Hazardous chemicals . . . . . . . . . . . . . . . . . 30

13.9 Transuranics (Elements with Atomic Numbers greater than 92) . 30

13.10 Uranium Oxide ......................... 31

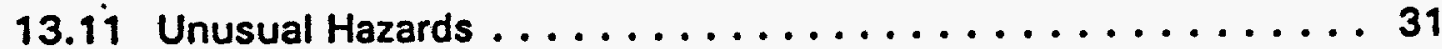

13.12 High Integrity Containers ................... 32

13.13 Filters/Filter Media ..................... 32

13.14 Slit Trench Shipments ..................... 33

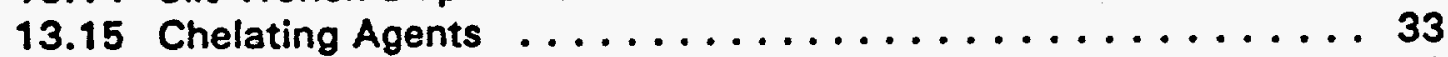

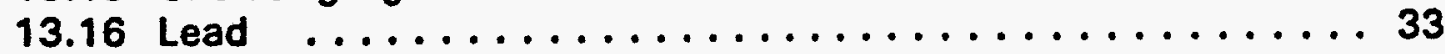

13.17 Mixed Waste ......................... 33

14.0 SHIPMENTS NOT AUTHORIZED BY CNSI RADIOACTIVE

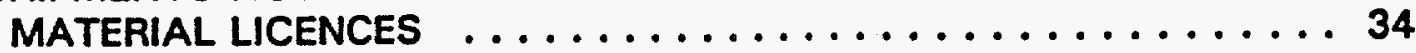

15.0 SHIPMENTS VIOLATING REGULATIONS OR CRITERIA . . . . . . . . . 35

\begin{tabular}{c|c} 
REV. & SHEET \\
7 &
\end{tabular}


APPENDIX A - TABLE OF ABBREVIATIONS ................ 36

APPENDIX B - DOCUMENTATION REQUIRED FOR CLASS C WASTE SHIPMENT ACCEPTANCE AT BARNWELL SITE $\ldots \ldots \ldots 37$

APPENDIX C - DISPLACEMENT VOLUME FOR STEEL DRUMS AND STANDARD B-25 BOXES . . . . . . . . . . . . 38

APPENDIX D - CNSI TELEPHONE NUMBERS . . . . . . . . . . . . . 39

APPENDIX E - DIRECTIONS FOR COMPLETING THE BROKER/PROCESSOR FORM .......................... 40

APPENDIX F - LEAD SHIELDING REQUEST $\ldots \ldots \ldots \ldots \ldots$

APPENDIX G - MANIFEST CONTINUATION SHEET . . . . . . . . . . . . . . . 42 


\subsection{SCOPE}

\subsection{Puroose}

Chem-Nuclear Systems, Inc. (CNSI) accepts low-level radioactive waste (radwaste) material for disposal at the Barnwell Waste Management Facility (Site) based upon compliance with the requirements described in this document, "Barnwell Waste Management Facility Site Disposal Criteria" (Site Criteria). This document outlines the responsibilities of the customer and CNSI and describes what constitutes an acceptable shipment for disposal at the Barnwell Site.

Any deviations from the requirements of the Site Criteria must be approved by the General Manager, Barnwell Site or his designee to avoid refusal or surcharges.

\subsection{Applicability}

This document applies to any individual shipping radwaste to the Site and to CNSI personnel involved with shipping and receiving waste shipments for disposal at Barnwell. A copy of the Site Criteria should be retained by the customer's employees responsible for the packaging and shipping of radwaste to the Barnwell Site for disposal.

Any questions regarding the Site Criteria, CNSI Licenses, Prior Notification Plan or Waste Shipment Scheduling Plan should be directed to the Barnwell Regulatory Affairs/Licensing Department (Telephone: 803-259-1781) unless otherwise specified.

\subsection{REFERENCES}

All customers shipping radwaste material to the Barnwell Site shall comply with the following applicable documents:

2.1 CNSI's South Carolina Department of Health and Environmental Control (DHEC) Radioactive Materials License, No. 097

2.2 CNSI's United States Nuclear Regulatory Commission (NRC) Radioactive Materials License, No. 12-13536-01.

2.3 U.S. Department of Transportation (DOT), Code of Federal Regulations, Title 49

2.4 U.S. NRC, Code of Federal Regulations, Title 10 


\subsection{S.C. DHEC Regulation 61-83, Transportation of Radioactive Waste Into or With South Carolina}

2.6 U.S. NRC IE Information Bulletin No. 83-10.

\subsection{GENERAL INFORMATION}

3.1 CNSI Telephone Numbers

The telephone numbers of CNSI offices are listed in Appendix D.

\subsection{Normal Hours of Qperation}

The normal hours of operation are Monday through Friday, 8:00 a.m. to 5:00 p.m.

\subsection{Holidays}

CNSI normally observes the following holidays and the Barnwell Site will be closed for business on the indicated dates or as specifically noted in separate correspondence:

New Year's Day

Good Friday

Memorial Day

Independence Day

Labor Day

Thanksgiving Day and the day after

Christmas Day and the day before/after

The Site will normally be closed all three days during a three-day weekend holiday.

\subsection{Pre-Shipment requirements}

The Site accepts radwaste by public highway only. The following requirements shall be met before shipping any radwaste to the Site.

3.4.1 Before the receipt of any radwaste, a contract, purchase order or a written letter of authorization in form and substance acceptable to CNSI, certifying compliance with the Site Criteria, References 2.1 and 2.2, and any subsequent changes, should be in the possession of CNSI's Marketing Department. 
3.4.2 Unless prior agreement has been made between CNSI Marketing and the customer, "collect" freight shipments shall not be accepted at the Site. Any demurrage charges shall be paid by the customer.

3.4.3 All waste generators, unless otherwise exempted by the State of South Carolina, shall have a valid S.C. Radioactive Waste Transport Permit (See Reference 2.5).

3.4.3.1 Before any shipper transports or causes to be transported radioactive waste into the State of South Carolina, they shall purchase an annual Radioactive Waste Transport Permit, (RWTP), from South Carolina Department of Health and Environmental Control, (DHEC). Shipper/ generator shall ensure that the RWTP is current and valid.

3.4.3.2 All sections of RWTP applications shall be completed, signed and received by DHEC 30 days before shipping date.

3.4.3.3 Permit Fees will be annually determined and assessed by DHEC based on the following classifications:

3.4.3.2.1 Class $X$. More than an annual total of 75 cubic feet or more than 100 curies of radioactive waste for disposal within the State.

3.4.3.2.2 Class $Y$. An annual total of 75 cubic feet or less of radioactive waste consisting of 100 curies or less total activity for disposal within the State.

3.4.3.2.3 Class Z. Any shipment of radioactive waste which is not consigned for storage or disposal within this State, but is transported into or within the State. 
Reference 2.5 and permit applications may be obtained from the following office:

S.C. DEPARTMENT OF HEALTH AND ENVIRONMENTAL CONTROL

Bureau of Radiological Health

Division of Radioactive Material

Licensing and Compliance

2600 Bull Street

Columbia, S.C. 29201

Telephone: 803/734-4626 or 4632

Fax Number: 803-799-6726

3.4.4 All waste shippers shall obtain a Shipment Identification (ID) Number from the CNSI Barnwell Waste Shipment Scheduling Plan/Prior Notification Plan Department, (WSSP/PNPI prior to shipping.

3.4.5 The Shipment ID Number shall be placed on the proper shipping papers to provide verification to carriers and others involved in radwaste transport and the Site receiving personnel that the radwaste shipment has been authorized and space is available.

3.4.6 Radwaste shipments that arrive at the Site without a Shipment ID Number shall NOT be accepted.

3.4.7 All shipments shall meet the requirements of Reference 2.3 for acceptance at the Site.

NOTE: INDIVIDUAL WASTE CONTAINERS MAY BE INSPECTED TO DETERMINE CONTENT AND/OR PHYSICAL FORM.

3.5. Shipment Prior Notification

Shippers shall comply with all notifications (written and telephone) in accordance with Step 5.3.

3.6 Shipment Documentation

The following documents shall accompany the shipment:

3.6.1 The Barnwell Waste Management Facility's Radioactive Shipment Manifest Form, No. CNS-201, (RSM).

NOTE: BROKER/PROCESSORS ARE REQUIRED TO USE THE CNS-201-B MANIFEST FORM (RSM) 
3.6.2 A Broker/Processor Form is required when more than one generator's waste is present in the shipment. (See Appendix E).

3.6.3 S.C. DHEC Radioactive Waste Shipment Prior Notification and Manifest Form (DHEC 802 Form).

NOTE: APPLICABLE ONLY TO SHIPMENTS GREATER THAN 75 CUBIC FEET AND/OR GREATER

THAN 1 CURIE

3.6.4 S.C. DHEC Radioactive Waste Shipment Certification Form (DHEC 803 Form).

3.6.5 Complete isotopic analysis printout or equivalent for aqueous filter media, filters and resins. (See Step 13.13).

3.6.6 Documentation Required for Class " $\mathrm{C}$ " Waste Shipment (See Appendix B).

3.6.7 Written statement of any unusual hazards and/or precautions that must be taken. (Refer to Step 13.11).

3.6.8 High Integrity Container Certification. (Refer to Step 13.12).

3.6.9 A DOE/NRC Form 741 for SNM when required.

\subsection{Offloading Schedule}

3.7.1 All arriving shipments shall be offloaded in order of arrival.

3.7.2 Special shipments shall be offloaded in accordance with contractual or other arrangements made in advance.

3.7.3 Special casks and other shipments that require non-routine operations for offloading may be deferred in the offloading routine to an appropriate time for commencement of handling such as 8:00 a.m. of the next day.

3.7.4 License and criteria limitations, weather or Site ground conditions, darkness and crane availability are all key items that may cause delays or rearrangements of shipments in offloading. 
3.8 Driver Check-In Precedure

3.8.1 Present shipping papers to Security guard at Main Gate Security.

3.8.2 Obtain tracking form and complete.

3.8.3 CNSI Security guard shall time stamp the driver's tracking form, RSM form and/or the Bill of Lading.

3.8.4 CNSI Security guards shall copy paper work and notify Health Physics (Incoming) of shipment arrival.

3.8.5 Health Physics will obtain shipping papers and tracking form from CNSI Main Gate Security.

3.9 Delays

3.9.1 CNSI shall not be responsible for transport equipment detention or special equipment demurrage charges assessed by the carrier. Payment of detention charges shall be the responsibility of the customer.

3.9.2 CNSI assumes no responsibility for transport equipment delays or special detention charges assessed by the carrier due to weather delays, improper paperwork, decontaminating vehicles or containers, violation of Federal and/or state requirements or other shipment discrepancies.

\subsection{Retrievability of Disposed Material}

All materials disposed of at the Site become the property of the

- State of South Carolina. No provision or authority exists for material retrieval following disposal.

\subsection{Equipment Storage}

Loading, storage or exchange of pallets, liners or centainers for third parties will not be accommodated at the Barnwell Site.

\begin{tabular}{|l|l|l|l|}
\hline DOCUMENT & $\begin{array}{c}\text { AEV. } \\
\vdots\end{array}$ & SHEET & 10 \\
\hline
\end{tabular}




\subsection{WASTE SHIPMENT SCHEDULING PLAN (WSSPI}

\subsection{General}

4.1.1 Due to a yearly volume limitation imposed by the State of South Carolina, it has been necessary for CNSI to develop and implement a Waste Shipment Scheduling Plan. The Waste Shipment Scheduling Plan, (WSSP), replaces the Volume Allocation Plan for the Barnwell Site.

4.1.2 The WSSP is established to conform to the Low-Level Radioactive Waste Policy Amendments Act of 1985 (ACT). Under this Act, all radwaste generated by the Southeast Compact states will be accepted for burial provided the waste meets requirements of Reference 2.1 and 2.2. Out-of-region generators may dispose of waste as volume is available in accordance with the Act.

4.1.3 Any questions regarding this plan should be addressed to the General Manager, Barnwell Site or his designee.

\subsection{Shipment Scheduling}

4.2.1 Shipment scheduling shall be performed by the radwaste generator or his authorized agent.

4.2.2 All customers shall contact the CNSI WSSP/PNP Department to request volume and schedule shipments. A CNSI Shipment ID Number shall be assigned to each shipment.

4.2.3 All Southeast Compact generators should schedule monthly waste volume under Shipment ID Numbers by the 10 th of the month that waste will be shipped.

\subsection{PRIOR NOTIFICATION PLAN (PNP)}

\subsection{General}

The Prior Notification Plan is required by Reference 2.5 and CNSI. Questions concerning DHEC notifications shall be directed to DHEC. DHEC 802 Form and DHEC 803 Form must be obtained from DHEC.

\subsection{Instructions}

5.2.1 Complete forms as indicated on the reverse side.

B-15 


\subsubsection{Shippers shall use the CNSI Shipment ID Number in Item 4 (Shipment Identification Number) of the DHEC 802 Form.}

5.2.3 Distribute the DHEC 802 Form as follows:

5.2.3.1 One copy mailed or faxed to the DHEC office in Columbia, South Carolina.

5.2.3.2 One copy mailed or faxed to CNSI WSSP/PNP Department at Barnwell.

5.2.3.3 One copy to accompany the shipment.

5.2.4 A completed copy of the DHEC 803 Form shall accompany the shipment.

\subsection{PNP Notifications}

5.3.1 CNSI and DHEC must receive the 802 Form 72 hours prior to shipment being transported into or within the State of South Carolina.

5.3.2 Shippers shall keep CNSI's WSSP/PNP Department and DHEC (803/253-6497) informed of all data changes concerning the DHEC 802 Form and all shipment cancellations.

5.3.3 Shipment departure notification and updates shall be given to the CNSI's WSSP/PNP Department when the shipment leaves the customer's facility.

\subsection{RADIOACTIVE SHIPMENT MANIFEST (RSM) FORMS (CNS-201)}

\subsection{General}

6.1.1 Unless otherwise approved by the Barnwell Regulatory Affairs/Licensing Department, only the CNSI RSM forms shall be accepted.

6.1.2 RSM forms are obtainable from the CNSI WSSPIPNP Department.

6.1.3 RSM Forms are inspected by CNSI personnel and the onsite DHEC official prior to shipment acceptance. Other state and federal regulatory agency inspections may also be performed. 
6.1.4 Improperly prepared RSM Forms will result in acceptance delays or refusal of the shipment.

6.1.5 A signed copy of the shipment manifest shall be returned to the shipper within seven days after the shipment has been acceated for disposal at the Site.

\subsection{Instructions}

6.2.1 RSM forms shall be completed per instructions located on the reverse side of the form and in accordance with Section 6.4 below.

NOTE: SEE SECTION 6.4 FOR COMPLETING MANIFEST CONTINUATION SHEET WHENEVER AN INDIVIDUAL DISPOSAL PACKAGE CONTAINS MORE THAN ONE WASTE FORM (I.E., DRUM CONTAINING DEWATERED RESIN AND DEWATERED FILTERS). AN EXAMPLE OF COMPLETED FORM IS PROVIDED IN APPENDIX $\mathbf{G}$.

6.2.2 The disposal site copy of RSM forms shall accompany the shipment.

\subsection{Special Considerations}

6.3.1 All tetals shown on the RSM form shall match all accompanying paperwork for a given shipment.

6.3.2 All disposal volumes, activity, etc., shall be accurate when shipment is received for burial. If any changes are to be made after waste has been disposed, the generator shall make a written justification for necessity of change and an additional handling fee may be charged.

6.3.3 The weight listed on the RSM form is used by CNSI personnel to select the proper offloading technique for the particular package. Fallure to list correct package weight could result in personnel injury and/or equipment damage and/or DHEC investigation. Discrepancies of this type could result in a substantial penalty charge.

6.3.4 To determine the container volume or displacement volume of the package, refer to Step 7.0. 
6.3.5 The customer shall provide a written statement on or attached to the RSM form listing any unusual hazards. See Step 13.11.

NOTE: PRIOR TO SHIPMENT, NOTIFICATION OF UNUSUAL HAZARDS SHALL BE MADE TO THE BARNWELL REGULATORY AFFAIRS/LICENSING DEPARTMENT.

6.3.6 Additional dose rate information should be provided on the RSM if it is other than the highest dose rate on the disposable container. (i.e., $2000 \mathrm{mR} / \mathrm{hr}$ on top of liner).

\subsection{Individual Packages Containing Multiole Waste Forms}

6.4.1 Use manifest continuation sheets as necessary to fully describe each waste form within each disposal package.

6.4.2 List the radionuclides present in each waste form.

6.4.3 List the percent of activity or millicurie content of each radionuclide in each waste form.

6.4.4 List the total millicurie content for each waste form.

6.4.5 Indicate the physical form of each waste form.

6.4.6 Indicate the chemical form of each waste form. If the waste form contains chelating agents in quantities greater than $0.1 \%$, list the names and their weight percentages.

6.4.7 Describe each waste form. If the material is solidified, indicate what solidification media was used.

6.4.8 List the classification of each waste form, either AU, AS, B or C.

6.4.9 Provide gram weight of the Special Nuclear Material, (SNM), if present in the waste form.

6.4.10 Provide source pounds of source material if present in the waste form.

6.4.11 Provide the total weight of the disposal package and its content. 
6.4.12 Provide the cubic footage for each waste form. The combined cubic footage shall equal the total volume of the disposal container.

6.4.13 List the type of disposal container used, (i.e., steel drum, wooden box, HIC, etc.l.

6.4.14 Record the highest measured radiation level for each disposal container surface. Package surface may be the same as disposal container if a cask is not used.

Transport Index (TI) is applicable only to the actual N.R.C. or D.O.T. shipping package, (I.e., cask, drum, box, etc.) and not to liners and drums shipped inside of cask or other packages.

6.4.15 Record the results of contamination surveys performed on the disposal containers. Do not use "BKG" for background levels unless the background level is indicated in this column.

6.4.16 If fissile radioactive material is being shipped, record the fissile class of the material as appropriate.

6.4.17 Record the type of D.O.T. labels or markings are used on each container such as: Radioactive $W-1, Y-11, Y-111$, Radioactive LSA, etc.

\subsection{VOLUME MEASUREMENT CRITERIA}

7.1 Disposal charges shall be based on the total displacement volume of the package utilized.

7.2 Standard shaped packages, (square, rectangular, cylinder), shall be sized using routine external measurements. Displacement volumes of steel drums up to 100 gallons and standard B-25 boxes are provided in Appendix $\mathbf{C}$.

7.3 The volume of any off-shaped package (i.e., with protrusions, legs, flanges, etc.l, shall be agreed to by CNSI Marketing and the customer prior to shipment. Odd-shaped packages received on Site without prior agreement of total displacement volume shall be measured by $\mathrm{CNSI}$ and disposal charges shall be assessed accordingly.

7.4 All box shipments are routinely measured by CNSI. Measurements taken are rounded to the nearest one-half inch.

B-19 
7.5 External bracework is included in total gross box measurements and displacement volume calculations. These pieces shall hold one box away from another creating void space which cannot be utilized. In the case of bulging boxes, the measurements are taken at the bulge. (The bulge will keep the box from being "snugged" up against another).

NOTE: BULGING BOXES MUST MAINTAIN COMPLETE COMPLIANCE WITH REFERENCE 2.3.

7.6 Skids or pallets are not included in the measurements.

7.7 The individual container volume is rounded off to the nearest tenth of a cubic foot. (128.64 cubic feet would be 128.6 cubic feet).

7.8 Cylindrical liner measurements are based on the outside maximum diameter and the maximum planar height.

\subsection{WASTE CLASSIFICATION AND PACKAGING}

8.1 All shipments received at the Barnwell Site shall be properly classified and marked in accordance with $10 \mathrm{CFR}$ 61.55. The waste class (A-U, A-S, B or C) shall be durably marked on top of the disposable container and clearly legible.

NOTE: STABLE WASTE - WASTE THAT IS BY FORM STABLE (I.E.. METAL REACTOR COMPONENTS) OR HAS BEEN RENDERED STABLE BY PLACEMENT IN A HIGH INTEGRITY CONTAINER OR BY PROCESSING WITH AN APPROVED SOLIDIFICATION MEDIA. AN APPROVED MEDIA IS ONE FOR WHICH SPECIFIC APPROVAL HAS BEEN GRANTED BY DHEC. ANY SUCH PROCESSING WITH A MEDIA MUST ELIMINATE VOID SPACES IN CONTAINERS TO THE EXTENT PRACTICABLE. CLASS A STABLE, CLASS B AND CLASS C WASTES SHALL BE FILLED TO NO LESS THAN 85\% FILLED OR BE PLACED IN APPROVED HIGH INTEGRITY CONTAINERS, DISPOSED IN A CONCRETE DISPOSAL OVERPACK, OR PLACED IN THE SLIT TRENCH. UNSTABLE WASTE - ALL OTHER WASTE THAT COMPLIES WITH ALL OTHER LICENSE REQUIREMENTS EXCEPT THOSE LISTED FOR STABLE WASTE.

8.2 Additional information for Class $C$ waste shlpments shall be provided in accordance with Appendix $B$. Class $C$ documentation must be received by the Barnwell Regulatory Affairs/Licensing Department prior to shipment. 
NOTE: DISPOSAL OF CLASS C WASTE MUST BE ACHIEVED THROUGH ONE OF THE FOLLOWING: THE TOP OF THE WASTE MUST BE A MINIMUM OF FIVE METERS BELOW THE TOP SURFACE OF THE WASTE TRENCH; DISPOSED IN TRENCHES EQUIPPED WITH INTRUDER BARRIERS; OR PLACED IN SITE-PROVIDED CONCRETE OVERPACKS.

8.3 Radwaste containing Special Nuclear Material (SNM) (U-233 and U-235) shall comply with Step 13.7 .

8.4 Each disposable container shall be marked/labeled with one of the following waste classifications: Class A-U (unstablel, Class A-S (stable, Class B or Class C.

NOTE: THE RSM FORM SHALL INDICATE THE WASTE CLASS AS: A-U, A-S, B OR C FOR EACH DISPOSABLE CONTAINER LISTED.

8.5 The package identification and other required marking and labeling shall be clearly visible on the shipping package. Special emphasis should be directed to this whenever wrapping materials are placed on the shipping package.

8.6 The waste classification for disposal packages that contain two or more inner packages shall be determined for each inner container. The most restrictive classification shall be indicated on the outer disposal container. (Example: Overpack containing one Class A Stable and one Class $\mathrm{C}$ drum shall be marked as Class $\mathrm{C}$ wastel.

8.7 Cardboard boxes, corrugated paper drums, etc., are NOT acceptable containers for disposal.

8.8. Unless otherwise authorized by the Barnwell Regulatory Affairs/ Licensing Department, radwaste shall be contained in wooden or steel containers or approved high integrity containers.

NOTE: DISPOSAL CONTAINERS SHALL NOT BE CORRODED TO THE POINT OF CONTAINER DEGRADATION. CONTAINERS HAVING MINOR SURFACE RUST ARE ACCEPTABLE, BUT SHALL MEET AS A MINIMUM, STRONG TIGHT CONTAINER CRITERIA.

8.9 All wooden boxes shall be banded with metal bands.

8.10 Boxes shall be of waterproof construction or properly covered during transit. 
8.11 Drums or other containers filled with non-radioactive materials shalı NOT be used for shielding.

8.12 Any supplemental shielding, interior or exterior to the shipping container shall have approval from the Barnwell Regulatory

Affairs/Licensing Department prior to shipping.

8.13 A yan is not considered a shipping container.

\subsection{VAN SHIPMENTS}

\subsection{Drums}

CNSI utilizes a mechanical lifter for offloading drums weighing 1000 pounds or less. Open-top vans or flatbed trailers are the preferred method of shipment for drums weighing less than 1000 pounds.

NOTE: MAXIMUM GROSS WEIGHT OF ANY NON-PALLETIZED DRUM SHALL NOT EXCEED 1500 POUNDS. ALL DRUMS ABOVE 1500 POUNDS SHALL BE PALLETIZED.

9.1.1 Non-palletized drums greater than 1000 pounds shall have, prior to shipment, approval by the General Manager of Disposal Operations or his designee.

9.1.2 Drums shall not be placed on their sides.

9.1.3 Drum rings and bolts shall be secured properly and be structurally strong enough to support the weight of the drum while offloading.

9.1.4 Lever-lock closure devices shall have prior approval before receipt.

9.1.5 Drums shall comply with Reference 2.3. Bulging lids shall not exceed height of closure ring; bulging bottoms shall not extend below bottom ring of drums.

9.1.6 Drums may be double stacked with proper bracing, provided the heavier drums are on the bottom.

9.1.7 Class A Unstable waste shall not be placed on the same pallet with Class $\mathbf{B}$ or Class $\mathbf{C}$ waste.

9.1.8 Class A Unstable waste and Class A Stable waste may be loaded on the same pallet. 
9.1.9 Class A Stable waste and Class B and Class C waste may be loaded on the same pallet.

9.1.10 Palletized drums may be double stacked.

9.1.11 Pallets shall be considered sacrificial.

9.1.12 The recommended pallet for handling drums holds two parallel rows of three drums each (six drums total).

9.1.13 A three drum pallet (singular row of three drums) may be used if weight is a limitation.

9.1.14 Drums shall be banded together and secured to the pallet to prevent sliding off during handling.

9.1.15 Recommended pallet dimensions:

Length

6 Drum Pallet $72^{n}$

3 Drum Pallet 72"

$\frac{\text { Width }}{48^{\prime \prime}}$

$\frac{\text { Height }}{4^{n}}$

$4^{n}$

9.1.16 Small drums should be stacked in reasonable quantities so that a Radwaste Technician may remove the highest container without need of a platform.

9.1.17 Heaviest containers shall be on the bottom.

9.2 Packages Weighing Less Than 8,000 Pounds (CNSI Forklift Capacity)

9.2.1 Each package shall have a minimum clearance of three inches from the van walls.

9.2.2 Packages shall be elevated from the van floor and accessible to a forklift. The use of two $2^{\prime \prime} \times 4^{\prime \prime}$ boards nailed together is acceptable.

9.2.3 Each package shall have a top clearance of at least twelve inches in a closed van.

9.2.4 Steps 9.2.1 through 9.2.3 are not applicable to nonpalletized drums.

9.2.5 Dunnage used to establish spacing is considered sacrificial.

9.2.6 Package weight (See Step 6.3.3). 


\subsection{Packages Weighing More Than 8,000 Pounds}

9.3.1 Packages shall be provided with properly attached lifting devices.

9.3.2 Lifting devices shall be secured to the top of package for easy access.

9.3.3 Packages shall not be shipped in a closed, hard-top vehicle.

9.3.4 Each package shall have a minimum clearance of three inches from the van walls.

9.3.5 Shipments with boxes weighing more than 8,000 pounds and palletized drums shall be segregated.

9.3.6 Package weight (See Step 6.3.3).

9.3.7 Steps 10.2 and $\mathbf{1 1 . 1 2}$ are applicable.

9.4 Mixed Shipments (Drums, Boxes, Liners, etc. Contzining Class A, B and $C$ Wastel

9.4.1 Mixed shipments shall comply with Steps 9.1 through 9.3 as applicable.

9.4.2 Only Class A Unstable waste shall be segregated from Class $B$ and Class $C$ waste when shipped together on the same shipment.

9.4.3 When Class A Unstable waste is on the same shipment with Class $B$ and/or Class $C$ waste, the shipping papers shall list the location of the waste in the shipment.

EXAMPLE: "CLASS A UNSTABLE WASTE LOCATED IN THE FRONT WITH THE CLASS B IN THE REAR." THIS IS TO BE INDICATED ON THE BOTTOM OF THE RSM FORM.

9.4.4 Do not stack non-palletized drums on boxes nor boxes on non-palletized drums.

9.4.5 Palletized drums are considered as boxes. No segregation is necessary if boxes (less than 8,000 pounds) and palletized drums are on the same truck. 
9.4.6 Non-palletized drums or boxes may be loaded in the forward section of the van with definite segregation of the two types of containers. (Preferably non-palletized drums loaded in forward section of vanl.

9.4.7 Shipments containing palletized drums and boxes weighing more than 8,000 pounds shall be segregated.

9.4.8 Step 11.12 is applicable.

9.4.9 Improperly mixed shipments shall result in an additional offloading charge or refusal of the shipment.

\subsection{ELATBED TRAILER SHIPMENTS}

10.1 Flatbed trailer shipments shall comply with Step 9.0 as applicable.

10.2 Packages with attached lifting devices are not required to have bottom clearance.

10.3 Step 11.12 is applicable.

\subsection{CASK SHIPMENTS}

11.1 Customers using a licensed cask not owned by CNSI shall ensure that CNSI is a "Registered User" of the licensed cask prior to shipment to the Barnwell Site. This applies to all shipments requiring licensed containers.

11.2 All shipments shall strictly comply with the applicable Certificate of Compliance for the cask in use (lid torquing, sealing gaskets, weight restrictions, shoring requirements, etc.).

$11.3^{\circ}$ Failure to observe appropriate requirements shall result in the submission of noncompliance information to the appropriate regulatory agency.

11.4 Liners containing "Grapple Bails" are to be identified under the liner type section of the RSM.

11.5 All drums and/or boxes shall be palletized and pallets shall have proper lifting devices attached.

11.6 Disposable container and/or pallet shall have the lifting device secured at the top of the container(s). This is to prevent the cable from becoming caught under or between the container(s) or pallet. 
NOTE: LIFTING DEVICES SHALL BE OF SUFFICIENT LENGTH TO ALLOW RETRIEVAL AND CRANE HOOK-UP WITHOUT PHYSICALLY ENTERING THE CASK. THE BARNWELL REGULATORY AFFAIRS/LICENSING DEPARTMENT SHALL BE NOTIFIED PRIOR TO SHIPMENT OF ANY LIFTING DEVICE SUPPLIED WITH THE DISPOSAL CONTAINER THAT HAS BEEN ALTERED, REMOVED OR REPLACED.

11.7 For shipments consisting of high integrity container drums, Class A Stable, Class $B$ and Class $C$, the pallets on which the drums are placed are considered sacrificial since the pallets are used for proper placement in the trench.

11.8 When using pallets, the containers shall be positioned to remain balanced and stable on the pallet when lifted clear of the cask.

11.9 Class A Unstable waste shall not be placed on the same pallet with Class B or C waste. Class A Unstable waste and Class B or Class C waste may be placed in the same cask, but an additional charge will be added. The location of the waste shall be noted on the RSM form.

11.10 When tall, slender containers (i.e., demineralizers) are loaded on a pallet inside the cask, the containers shall be tied or secured together at the tops to prevent containers from falling off the pallets during offloading.

NOTE: THIS IS NOT REQUIRED FOR A SINGLE TIER OF DRUMS, I.E.: 55-GALLON, 83-GALLON ETC. WHICH ARE PLACED ON A PALLET.

11.11 Palletized drums inside a cask shall be loaded to prevent movement in such a manner that any shifted position of drums on the pallet will not increase radiation levels measured outside the cask. (Dunnage shall be removable with palletized loads).

11.12 A shipment consisting of individual disposal containers not on pallets shall have attached to each container a lifting device that will allow offloading by a single lift. EXAMPLE: Shipping 4 demineralizers without a pallet would require the use of a "D" ring with a 4-part spreader (spider). Each leg of the spider would be attached to one of the disposal containers.

11.13 Customer-provided lifting slings may be returned upon request at the customer's expense, provided:

11.13.1 The slings are not contaminated. 
11.13.2 Additional CNSI personnel exposure will not be accumulated.

11.13.3 Excessive loading time will not be incurred.

NOTE: THERE MAY BE AN ADDITIONAL CHARGE WHEN A RADIOLOGICAL SURVEY AND RELEASE OF SLINGS OR EQUIPMENT IS REQUESTED.

11.13.4 Metal/steel braided/twisted cables/fabric slings are not generally released from the Barnwell site due to difficulties in performing adequate radiological surveys.

\subsection{CONTAMINATION LIMITS OF PACKAGENEHICLE}

\subsection{General}

12.1.1 All shipments received at the Barnwell Site shall comply with contamination control limits of Reference 2.3.

12.1.2 Loose contamination on and between packages that may be obscured by various barriers (i.e., impact limiters, base plates, etc.) shall be considered. Contamination limits for the package, the barrier and the vehicie shall comply with References 2.3 and 2.6.

12.1.3 The receipt of excessive surface contamination on containers in casks or otherwise, is very undesirable from the standpoint of site cleanliness and contamination control. Customers should use all means at their disposal to ship containers with minimal surface contamination.

12.1.4 Notify the Barnwell Regulatory Affairs/Licensing Department prior to shipment of any smearable contamination on the disposal container and/or cask interior surface exceeding $50,000 \mathrm{dpm} / 100 \mathrm{~cm}^{2}$ betagamma and/or $2200 \mathrm{dpm} / 100 \mathrm{~cm}^{2}$ alpha.

12.1.5 Disposal containers that have been wrapped to prevent the spread of loose contamination shall have, prior to shipment, approval from the Barnwell Regulatory Affairs/Licensing Department. 
NOTE: THE CUSTOMER SHALL NOTIFY THE BARNWELL REGULATORY AFFAIRS/ LICENSING DEPARTMENT PAIOR TO DEPARTURE OF ANY SHIPMENT IN WHICH THE POTENTIAL EXISTS FOR AIRBORNE CONTAMINATION AND/OR EXCESSIVE SMEARABLE CONTAMINATION IS PRESENT. FAILURE TO PROVIDE TIMELY INFORMATION MAY RESULT IN SUBSTANTIAL SURCHARGES OR REFUSAL OF THE SHIPMENT. (SEE STEP 13.11)

\subsection{Floor Covering}

Plywood or other materials that are placed over the transport vehicle's flooring for contamination control shall be considered sacrificial, but will not be considered part of the burial volume. Time and/or supplies for floor covering removal will be chargeable.

\subsection{Decontamination Prior to Release}

Vehicles exiting the CNSI site shall be decontaminated to release limits described in Step 12.4 prior to release. Charges for decontamination services to comply with these levels shall be assessed as necessary.

12.4 Contamination Release Limits for Vehicles Exiting the Barnwell Site

12.4.1 Enclosed vehicles used solely for the transport of radioactive materials (Exclusive Use) and properly marked "For Radioactive Materials Use Only."

12.4.1.1 Fixed contamination shall not exceed $10 \mathrm{mR} / \mathrm{hr}$ on contact with the interior surface or $2 \mathrm{mR} / \mathrm{hr}$ at one meter from the interior surface.

12.4.1.2 Fixed contamination shall not exceed 0.5 $\mathrm{mR} / \mathrm{hr}$ at any exterior accessible surface.

12.4.1.3 Removable contamination shall not exceed 220 $\mathrm{dpm} / 100 \mathrm{~cm}^{2}$ alpha and $2200 \mathrm{dpm} / 100 \mathrm{~cm}^{2}$ beta-gamma in the interior or on the exterior of the vehicle.

12.4.2 Enclosed vehicles used solely for transoort of radioactive material (Exclusive Usel and NOT marked according to 12.4 .1

$$
\text { B-28 }
$$


12.4.2.1 Fixed contamination shall not exceed 0.5 $\mathrm{mR} / \mathrm{hr}$ at any accessible surface.

12.4.2.2 Removable contamination for beta-gamma shall not exceed $2200 \mathrm{dpm} / 100 \mathrm{~cm}^{2}$.

12.4.2.3 Removable contamination for alpha shall not exceed $220 \mathrm{dpm} / 100 \mathrm{~cm} 2$.

\subsubsection{Emoty Casks}

12.4.3.1 Fixed contamination shall not exceed 0.5 $\mathrm{mR} / \mathrm{hr}$ at any accessible surface unless cask is properly labeled and a completed Radioactive Shipment Record (RSR) accompanies the cask.

12.4.3.2 Removable external contamination for betagamma shall not exceed $2200 \mathrm{dpm} / 100 \mathrm{~cm}^{2}$.

12.4.3.3 Removable external contamination for alpha shall not exceed $220 \mathrm{dpm} / 100 \mathrm{~cm} 2$.

12.4.4 All Vehicles or Items for Unconditional Release

12.4.4.1 Fixed contamination shall not exceed 0.1 $\mathrm{mR} / \mathrm{hr}$ at any accessible surface.

12.4.4.2 Removable contamination for beta-gamma shall not exceed $220 \mathrm{dpm} / 100 \mathrm{~cm}^{2}$.

12.4.4.3 Removable contamination for alpha shall not exceed $22 \mathrm{dpm} / 100 \mathrm{~cm}^{2}$.

\subsection{SPECIAL CATEGORIES}

\subsection{Biological Material}

13.1.1 Plants, animals and by-products thereof are considered biological material. Glassware, etc., that at one time contained these materials may also be considered biological. All biological waste shall be packaged in accordance with this Section.

13.1.2 The inner container having a capacity of 55-gallons or less shall be in good condition and shall comply with DOT specifications for a strong tight container. 
13.1.3 The container shall have a watertight liner (i.e., polyethylene or equivalent) of at least 4 mils thickness.

13.1.4 The biological material shall be placed in the inner container and thoroughly layered with absorbent and slaked lime.

13.1.4.1 The lime used shall be commercially available slaked lime.

13.1.4.2 The absorbent used should be agricultural grade four vermiculite or medium grade diatomaceous earth.

13.1.4.3 The addition of lime and absorbent to biological material should be in a ratio of one part lime to ten parts absorbent to thirty parts biological material.

13.1.4.4 The addition of formaldehyde is strictly prohibited.

13.1.5 The watertight liner shall be hermetically (airtight) sealed by taping, tying or heat sealing.

13.1.6 The seal on the inner container is crucial to proper containment and shall be made in the following manner.

13.1.6.1 Crimp-top containers shall be closed with a 16lug closing tool.

13.1.6.2 The ring-and-bolt equipped containers shall be closed with an appropriate wrench.

13.1.6.3 Lever locks are not acceptable.

13.1.7 Inner container shall be placed upright in an outer container.

13.1.8 The Quter container shall be a new or properly recertified steel 17-H DOT specification container or equivalent.

13.1.9 The bottom of the outer container shall be covered with a minimum of four inches of absorbent material.

B-30 
13.1.10 After the inner container(s) is/are placed in the outer container, (two 5-gallon containers may be placed in a 30 gallon container or a 30-gallon container placed in a 55 gallon container, or one 55-gallon container placed in an 83-gallon container), it shall be completely surrounded to the top of the outer container with additional absorbent material and sealed.

13.1.11 Containers of small capacity may be used provided that the volume of the outer container is at least 1.5 times the volume of the inner container.

13.1.12 The outer container shall be equipped with a tamper-proof seal.

13.1.13 A refrigerated van shall be used to ship biological radwaste between April 1 and October 1, if transit time will exceed 48 hours from the time the biological radwaste is first removed from cold storage until arrival at the Site.

\subsection{Gaseous Waste}

13.2.1 Krypton 85 and Xenon 133 are acceptable in DOT specification cylinders or NRC approved sealed sources with internal pressures less than 1.5 atmospheres and less than 100 curies per container.

13.2.2 Sealed Tritium gas sources are acceptable provided:

13.2.2.1 The maximum activity of each source does not exceed 50 curies.

13.2.2.2 All sources are disposed of as entire devices to provide additional physical protection to the primary tritium source containment.

13.2.2.3 Sources requiring stabilization as determined by waste classification, (using the volume of the sealed source onlyl, are placed in high Integrity containers or encapsulated with an appropriate stabilization media.

13.2.2.4 The internal pressure of each source is less than 1.5 atmospheres. 
13.2.2.5 Methods used for stabilizing these sources shall be approved by the Barnwell Regulatory Affairs/Licensing Department prior to shipment.

\subsection{Sealed Sources or Special Form Radioactive Materials}

13.3.1 Sealed sources or special form radioactive material containing more than 5 curies of radioactive material with half-lives greater than 5 years shall not be received or disposed of except in a container which provides long-term containment.

NOTE: PRIOR TO SHIPMENT, THESE CONTAINERS SHALL BE EVALUATED AND APPROVED BY THE BARNWELL REGULATORY AFFAIRS/ LICENSING DEPARTMENT AND THE DEPARTMENT OF HEALTH AND ENVIRONMENTAL CONTROL.

13.3.2 Cement encapsulation of sealed sources to achieve stability may be acceptable provided the encapsulation method is approved by the Barnwell Regulatory Affairs/Licensing Department.

13.3.3 Waste classification for sealed sources is based on the actual source volume. Volumes for source housings or encapsulation media shall not be included.

\subsection{Liquid Radioactive Waste}

13.4.1 No liquid waste or solid waste containing liquids shall be received at the Barnwell Site.

13.4.2 Solidified liquid waste may be accepted provided it is solidified with one of the solidification media specified in Reference 2.1.

13.4.3 Hazardous organic solutions, solidified or otherwise, are not acceptable for disposal at the Site.

13.4.4 Solidified or processed waste containing non-hazardous scintillation products may be acceptable provided the scintillation products have been approved by S.C. DHEC. 
13.4.4.1 Scintillation products that have received S.C. DHEC approval shall be identified by product name on the shipment manifest.

\subsection{Qil}

Waste containing incidental or trace amounts of absorbed oil are acceptable, provided they do not exceed one percent $(1 \%)$ of waste volume in a container; however, waste streams can not be blended or mixed to obtain compliance.

\subsection{Pyrophoric Materials or Flammable Solids}

13.6.1 Pyrophoric or flammable solid material contained in waste shall be made inert to prevent self ignition during transport and disposal.

13.6.2 The inerting process shall be approved by the Barnwell Regulatory Affairs/Licensing Department prior to shipping.

13.6.3 No material that might react violently with water or moisture shall be accepted for disposal at the Barnwell Site.

\subsection{Special Nuclear Material (SNM) (U-233 and U-235 Onlv)}

13.7.1 All SNM waste shall be packaged in accordance with Reference 2.1 and 2.2.

13.7.2 The Barnwell Regulatory Affairs/ Licensing Department shall be notified prior to shipping SNM waste containing greater than 0.1 percent by weight chelating agents as determined prior to processing.

13.7.3 No package surface area on any side or projected plane shall be less than $2 \mathrm{ft}^{2}$. (Regular 30-gallon and larger packages are acceptable).

13.7.4 Shippers having individual packages in excess of 100 grams of U-235 shall provide with the shipment papers a statement indicating the percent confidence in their shipping values.

13.7.5 The Barnwell Regulatory Affairs/Licensing Department shall be notified prior to shipment of SNM packages exceeding 100 grams of U-235 in which the confidence in shipping value is less than 95 percent.

AEV.
7


13.7.6 No package shall contain greater than 350 grams of U-235 or 200 grams of U-233.

13.7.7 A vehicle shall not contain more than 4500 grams of $U$ 235 or 200 grams of U-233.

\subsection{Hazardous chemicals}

13.8.1 Waste material containing hazardous chemicals/agents and radioactive materials shall be acceptable for disposal only when the radiological hazard clearly exceeds the toxic chemical/agent hazard.

13.8.2 All shipments shall comply with Reference 2.1 regarding the assessment of chemical versus radiological hazards.

13.8.3 When any determination has been made as to the classification of the hazard, an independent evaluation of the radiological, biological and chemical hazards shall be performed and the reports shall be submitted to the Barnwell Regulatory Affairs/Licensing Department for review prior to shipment.

13.8.4 CNSI shall receive, review and maintain on file all reports of evaluations for DHEC review.

13.8.5 Upon completion of review and comment, the reports, if necessary, will be submitted by CNSI to DHEC for evaluation as to the acceptability of the waste material for disposal.

\subsection{Transuranics (Elements with Atomic Numbers greater than 92)}

13.9.1 Waste containing the transuranic nuclides are acceptable provided the following conditions are met.

13.9.1.1 The concentration limits specified in Reference 2.1 are not exceeded.

13.9.1.2 The transuranic nuclides are evenly distributed within a homogeneous waste form.

13.9.1.3 The transuranic content is incidental to the total activity.

13.9.2 All packages containing transuranics shall be clearly indicated on the accompanying RSM.

$\mid \begin{array}{r}\text { REV. } \\ 7\end{array}$


13.9.3 Smoke or gas detectors containing Americium-241 foils which exceed the limits specified in Reference 2.1 are acceptable for disposal provided the entire detector is received for disposal.

13.9.4 In-core detectors or other such devices which contain transuranics require approval by the Barnwell Regulatory Affairs/Licensing Department prior to shipping.

\subsection{Uranium Oxide}

Uranium oxide shipments are subject to heavy external contamination of containers. Precautions shall be taken to ensure that the shipping container contamination will be less than the limits specified in Reference 2.3.

\subsection{Unusual Hazards}

13.11.1 The shipper of radioactive material shall notify the Barnwell Regulatory Affairs/Licensing Department prior to departure of any shipment in which the possibility exists for unusual hazards.

13.11.2 Barnwell Regulatory Affairs/Licensing shall obtain approval of the General Manager, Barnwell Site, or his designee before authorizing the departure of any shipments with unusual hazards to the Site.

13.11.3 The shipper shall provide a written statement on or attached to the RSM Form containing information as to unusual hazards.

13.11.4 Wind, weather or other unusual circumstances may delay offloading this type shipment.

13.11.5 Unusual hazards include, but are not limited to, the presence of neutron sources or neutron emitters in the shipment, spills in or on shipping containers or vehicles, excessive external contamination levels on disposable containers (See Step 12.1.4), any non-routine waste processing event, any damage which has occurred to a disposable container or lifting device, etc.

\begin{tabular}{l|l} 
B-35 & $\begin{array}{r}\text { REV. } \\
7\end{array}$ \\
\hline
\end{tabular}




\subsection{High Integrity Containers}

13.12.1 Only high integrity containers approved by S.C. DHEC are acceptable for burial at the Site. Shippers shall ensure that a copy of the Certificate of Compliance $(C$ of $C)$ for the approved high integrity container as issued and amended by DHEC is on file with the Barnwell Regulatory Affairs/Licensing Department.

13.12.2 Polyethylene high integrity containers approved by DHEC containing Class $B$ or $C$ waste shall be disposed in approved concrete overpacks.

13.12.3 The Barnwell Regulatory Affairs/Licensing Department shall have signed documentation on file from the shipper or notification from DHEC that the shipper has received and will adhere to the requirements of the $C$ of $C$.

13.12.4 A certification that the shipper has stored, handled and used the high integrity container in accordance with the $\mathrm{C}$ of $\mathrm{C}$ shall accompany the shipment to the Barnwell Site.

\subsection{Filters/Filter Media}

For each shipment containing resin or other aqueous filter media (including filters), a complete isotopic analysis shall be provided with the shipment. The analysis shall identify the following:

\subsubsection{Disposal package number}

13.13.2 Waste description

13.13.3 Radionuclides present

13.13.4 Total curie content

13.13.5 Resin/filter media volume (cc or $\mathrm{Ft}^{3}$ )

13.13.6 The specific activity of each radionuclide and the total radionuclide concentration shall be expressed in microcuries/cubic centimeter or curies/cubic meter and transuranic radionuclides in nanocuries/gram.

NOTE: THESE REQUIREMENTS ARE NOT APPLICABLE TO AIR FILTERS. 


\subsection{Slit Trench Shipments}

13.14.1 Cask shipments which are required to be offloaded using the horizontal offload technique shall have approval of the General Manager, Barnwell Site or his designee prior to shipping.

13.14.2 Horizontally offloaded shipments shall have the liner removal device approved by the General Manager, Barnwell Site or his designee, prior to shipping.

13.14.3 Liners up to 61 inches in diameter offloaded vertically may be disposed in the slit trench.

\subsection{Chelating Agents}

13.15.1 Waste containing chelating agents with concentrations before solidification greater than 0.1 percent but less than 8 percent by weight is acceptable, provided it is stabilized with one of the solidification agents specified in Reference 2.1. These wastes are only acceptable as Class A-S, B or c.

13.15.2 Waste containing chelating agents greater than 8 percent by weight, before solidification, is not acceptable.

13.15.3 Waste containing chelating agents shall be segregated from other Class $B$ and $C$ waste. Segregation can be achieved by placement in concrete overpack, or segregation by at least ten feet in all directions of nonconcrete overpack waste.

13.15.4 The name and percent of chelating agents in the waste, before solidification, shall be listed on the RSM form.

\subsection{LEAD}

Non-radioactively contaminated lead specifically used for shielding purposes may be acceptable for disposal, but shall be evaluated by the Barnwell Regulatory Affairs/Licensing Department. Information requested on Appendix $F$ shall be provided for evaluation.

\subsection{MIXED WASTE}

13.17.1 No mixtures of radioactive waste and hazardous waste as defined by Title 40 Code of Federal Regulations (CFR) Part 261 and S.C. Management Regulation 61-79.261 will be accepted.

TREY.

SHEET 
13.17.2 A mixture of radioactive waste and waste which was classified as hazardous solely because it exhibited one or more of the hazardous characteristics defined in 40 CFR 261 Subpart $C$ but has been treated in a manner such that it no longer exhibits any of the characteristics, will be reviewed for acceptance on a case-by-case basis. As required by 40 CFR 261.24, the Toxicity Characteristic Leaching Procedure shall be used.

13.17.3 A description of the treatment process and results of the analytical tests of the final waste shall be submitted to CNSI for evaluation prior to shipment.

\subsection{POLYCHLORINATED BIPHENYL WASTE (PCB)}

13.18.1 No PCB's or PCB items as defined in 40 CFR 761 will be accepted for disposal.

13.18.2 The Barnwell Regulatory Affairs/Licensing Department shall have documentation or analytical results from the shipper substantiating the absence of PCB's for PCB suspect waste. This information shall be provided prior to shipment.

\subsection{ASBESTOS}

13.19.1 Packages containing radioactively contaminated asbestos waste only shall be identified as asbestos under the waste description of the RSM and continuation sheet.

13.19.2 Packages containing asbestos waste $10.1 \%$ or greater by weight) shall be identified on the manifest continuation sheet as specified in Section 6.4.

13.19.3 OSHA Asbestos standard 29 CFR 1910.1001 requires affixment of warning labels on asbestos containing waste packages.

\subsection{SHIPMENTS NOT AUTHORIZED BY CNSI RADIOACTIVE MATERIAL LICENSES}

14.1 If a proposed shipment does not conform to the requirements of References 2.1 or 2.2, CNSI Marketing shall be contacted by the customer and provided with detailed information on the packaging and contents of the shipment. 
14.2 CNSI Marketing should be contacted for the procedures for obtaining a variance. Shipments requiring variances shall be subject to a special surcharge.

\subsection{SHIPMENTS VIOLATING REGULATIONS OR CRITERIA}

15.1 The customer shall be notified by telephone of any nonconformance with References $2.1,2.2,2.3,2.4,2.5,2.6$ or this Site Criteria.

15.2 DHEC officials shall be notified of any waste shipments where a violation of applicable regulations or license conditions has been found.

15.3 The customer shall have twenty-four hours to send a representative to inspect the shipment provided the violation is discovered during receipt inspection or early stages of offloading.

15.4 Twenty-four hours after customer notification, if customer inspection is waived, or if efforts to contact the customer are unsuccessful, the shipment may be offloaded with DHEC approval.

15.5 If deemed necessary and with the approval of DHEC, the shipment may be returned to the customer.

15.6 The customer shall be billed for any special services, detention and additional handling charges on shipments received with violations/ discrepancies. 
APPENDIX A

TABLE OF ABBREVIATIONS

(1 PAGE) 


\section{APPENDIX B \\ DOCUMENTATION REQUIRED FOR CLASS C WASTE SHIPMENT ACCEPTANCE AT THE BARNWELL SITE \\ (4 PAGES)}




\section{ABBREVIATIONS}

C of C

CFR

CNS1

DHEC

DOE

DOT

DPM

HIC

LPRM

LSA

NRC

OSHA

PCB

PNP

RADWASTE

RSM

RWTP

SITE

SITE CRITERIA

SM

SNM

TCLP

WSSP
Certificate of Compliance

Code of Federal Regulations

Chem-Nuclear Systems, Inc.

South Carolina Department of Health and

Environmental Control

Department of Energy (U.S.)

Department of Transportation (U.S.)

Disintegrations Per Minute

High Integrity Container

Low Power Range Monitor

Low Specific Activity

Nuclear Regulatory Commission (U.S.)

Occupational Safety and Health Administration

Polychlorinated Biphenyl

Prior Notification Plan

Low-Level Radioactive Waste

Radioactive Shipment Manifest

Radioactive Waste Transport Permit

Barnwell Waste Management Facility

Barnwell Waste Management Facility Site

Disposal Criteria

Source Material

Special Nuclear Material

Toxicity Characteristic Leaching Procedure

Waste Shipment Scheduling Plan 


\section{DOCUMENTATION REQUIRED FOR CLASS C WASTE SHIPMENT ACCEPTANCE AT THE BARNWELL SITE}

These instructions outline documentation required for Class $\mathbf{C}$ waste shipment acceptance. This documentation is required in addition to other applicable requirements of S.C. License 097, Barnwell Site Criteria and State and Federal regulations. Waste classification must be performed in accordance with 10 CFR 61.55, "Waste Classification" and License 097, Amendment 45, Condition 31. Detailed explanation is provided in the NRC Low Level Waste Licensing Branch Technical Position on Radioactive Waste Classification.

This additional information will be used to evaluate the shipment for acceptance. In order to have consistency, the information provided on the attached form shall be completed and sent with each shipment.

\section{Waste Description}

The item, component or medium in which the radioactivity is present and the physical nature of the waste should be described. Example: irradiated nonfuel bearing reactor components, control rod blades, 304 stainless steel.

\section{Container Volume}

The disposal volume $\left(\mathrm{ft}^{3)}\right.$ is used to determine allocations and disposal fees. The volume of waste materials only shall be used in determining radionuclide concentrations.

\section{Container Type}

The disposal container should be clearly identified in terms of its size, composition and construction. The approximate arrangement of the waste inside the container shall also be specified. 
4. Radiation Levels

The maximum dose rate of the disposal container in air at one (1) foot shall be clearly stated.

5. Total Curie Content

Self explanatory.

6. Radionuclide Concentrations

A detailed list of the concentrations of contained radionuclides in microcuries per cubic centimeter and concentrations of each transuranic radionuclide in nanocuries per gram shall be provided. The total activity of each radionuclide in the waste material shall also be given.

7. Waste Classification Method

The methods used to calculate radionuclide concentrations in Class $\mathrm{C}$ waste shall be specified. The NRC's Branch Technical Position discusses acceptable methods that can be used to classify wastes. Briefly describe the methods used to determine radionuclide concentrations. 


\section{CLASS "C" WASTE CLASSIFICATION RECORD}

Generator Name

Shipment Number

Volume Allocation Number

1. Waste Description:

2. Volumes: (a) Container Volume $\left(\mathrm{Ft}^{3}\right)$ (b) Waste Volume $\left(\mathrm{cm}^{3}\right)$

3. Container Type:

4. Radiation Levels: Maximum Dose Rate of Disposal Container at One (1) Foot:

5. Total curie content:

6. Radionuclide concentrations:

$\begin{array}{llll} & \text { Each Radionuclide } & & \text { Each Transuranic } \\ & \text { Concentration } & \text { Total Activity of } & \text { Concentration } \\ \text { Radionuclides } & \text { (Microcuries/cc) } & \text { Each Radionuclide } & \text { (Nanocuries/gm) }\end{array}$

Total Concentration of all Transuranics 


\section{CLASS " $C$ " WASTE CLASSIFICATION RECORD}

\section{Generator Name}

7. Waste Classification Methods:

(a) Describe method:

TITLE:

COMPANY: 


\section{APPENDIX C}

DISPLACEMENT VOLUME FOR STEEL DRUMS AND STANDARD B-25 BOXES

(1 PAGE) 


\section{DRUM VOLUMES}

*STANDARD B-25 BOX

\author{
5-GALLON DRUM \\ 30-GALLON DRUM \\ 52-GALLON DRUM \\ 55-GALLON DRUM \\ 79-GALLON DRUM \\ 83-GALLON DRUM \\ 85-GALLON DRUM \\ 89-GALLON DRUM \\ 96-GALLON DRUM
}

95 CUBIC FEET
.68 CUBIC FEET
4.10 CUBIC FEET
7.10 CUBIC FEET
7.50 CUBIC FEET
10.80 CUBIC FEET
11.30 CUBIC FEET
11.60 CUBIC FEET
12.10 CUBIC FEET
13.10 CUBIC FEET

- Volumes for other B-25 type boxes (i.e.: type A, drum overpacks, etc.) are to be obtained through the use of Section 7.0, Volume Measurement Criteria.

NOTE: TO OBTAIN A VOLUME FOR A DRUM OTHER THAN LISTED ABOVE, CONTACT THE BARNWELL REGULATORY AFFAIRS/LICENSING DEPARTMENT. 
APPENDIX D

CNSI TELEPHONE NUMBERS

(1 PAGE) 


\section{CNSI TELEPHONE NUMBERS}

Barnwell Office

Barnwell Fax

Waste Shipment Scheduling Office

Notification Plan Office

Mid-Western Region

Corporate Office/Southeast Region

Northeast Region

Western Region
1803) 259-1781

(803) 259-7230

(803) 259-3577

(803) 259-3578

(815) 467-3000

(803) 256-0450

(203) $677-0457$

(803) 256-0450
Barnwell, SC

Barnwell, SC

Barnwell, SC

Barnwell, SC

Channahon, IL

Columbia, SC

Avon, CT

Columbia, SC 


\section{APPENDIX E}

DIRECTIONS FOR COMPLETING THE BROKER/PROCESSOR FORM

(3 PAGES)

B-51

REV.

SHEET 


\section{DIRECTIONS FOR COMPLETING THE BROKER/PROCESSOR FORM}

1. Shipper - Person or Company making the shipment.

2. Shipment 1.D. Number - Enter acquired number from the Chem-Nuclear WSSP/PNP Department - (803)259-3577.

3. Waste Generator - List the waste generator, along with city and state location. A generator having more than one facility must identify the facility that generated the waste.

4. Permit Number - Enter the S.C. Radioactive Waste Transport Permit Number.

5. Waste Description - Provide general description of each waste form (i.e.: dewatered resins, solidified sludge in cement, lab trash consisting of paper and plastic, etc.).

6. Waste Volume - Enter the cubic footage for each waste form.

7. Nuclide - List the individual radionuclides for each waste form.

8. Nuclide Activity - List the radionuclide activities in millicuries for each waste form.

9. Total Activity - List the total activity in millicuries for each waste form.

10. Waste Class - List the appropriate waste class (A-U, A-S, B or C) for each waste form. 
CCHCMATOR VOLUAE AHO RCTIVITY TORH (onoxin/rnoclsson roan)

IHIPIA CHEM-NUCLEAR SYSTEIIS, INC. - CHANNAHON (1)

Ter

sutpneкт 1.0, но. 1190-190

(2)

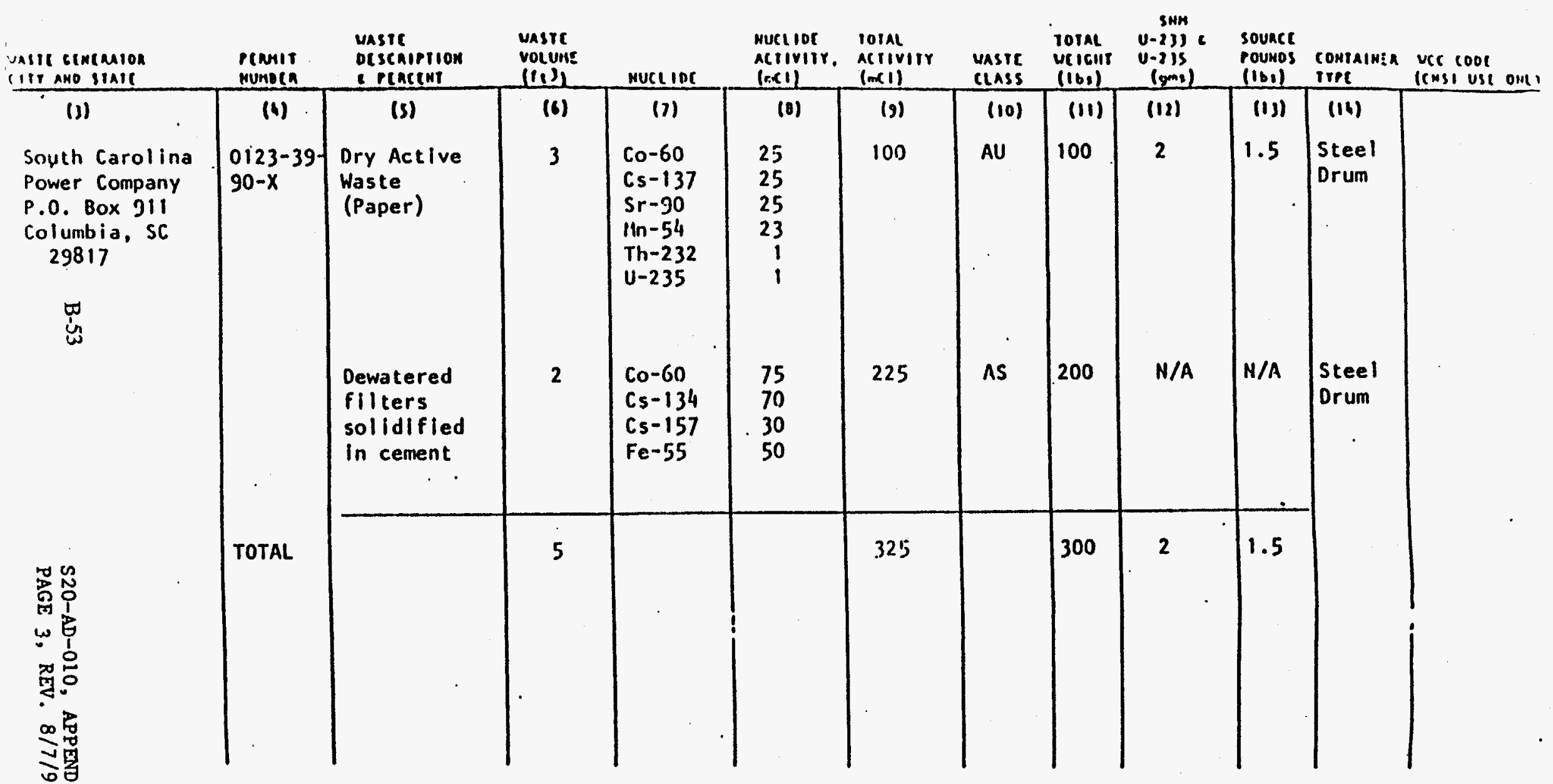


11. Iotal Weight - Enter total weight for each generator's waste.

12. Special Nuclear Material - List the total SNM grams for U-233 and U235 for each generator.

13. Source Pounds - List the source pounds for each generator.

14. Container Type - List the type of disposal container, (i.e.: steel box, wooden box, HIC, etc.).

INFORMATION ON THIS FORM MUST CORRESPOND WITH ALL DOCUMENTS PROVIDED WITH THE SHIPPING PAPERS. 
APPENDIX F

LEAD SHIELDING REQUEST

(1 PAGE) 


\section{LEAD SHIELDING REQUEST}

Lead used for radiation shielding purposes may be acceptable for disposal at the Barnwell Site. Requests for acceptance of non-radioactively contaminated lead specifically used for shielding purposes must be evaluated by Chem-Nuclear Systems, Inc., to ensure regulatory compliance. In order for Chem-Nuclear to evaluate your request, please provide the following information prior to making waste shipments containing lead shielding.

1. type of lead used (sheet, shot, etc.)

2. amount of lead used (pounds/thickness): please provide a detailed sketch of the waste packaging specifically showing the location and thickness of the lead.

3. container type and size (can be shown in sketch)

4. location of lead in container, i.e.: top, bottom, sides (can be shown in sketch)

5. description of waste requiring shielding (waste form, total activity, isotopic distribution and total volumel

6. waste classification (A, B or $C)$

7. approximate radiation dose rate prior to shielding

8. approximate radiation dose after shielding 
APPENDIX G

MANIFEST CONTINUATION SHEET

(1 PAGE) 


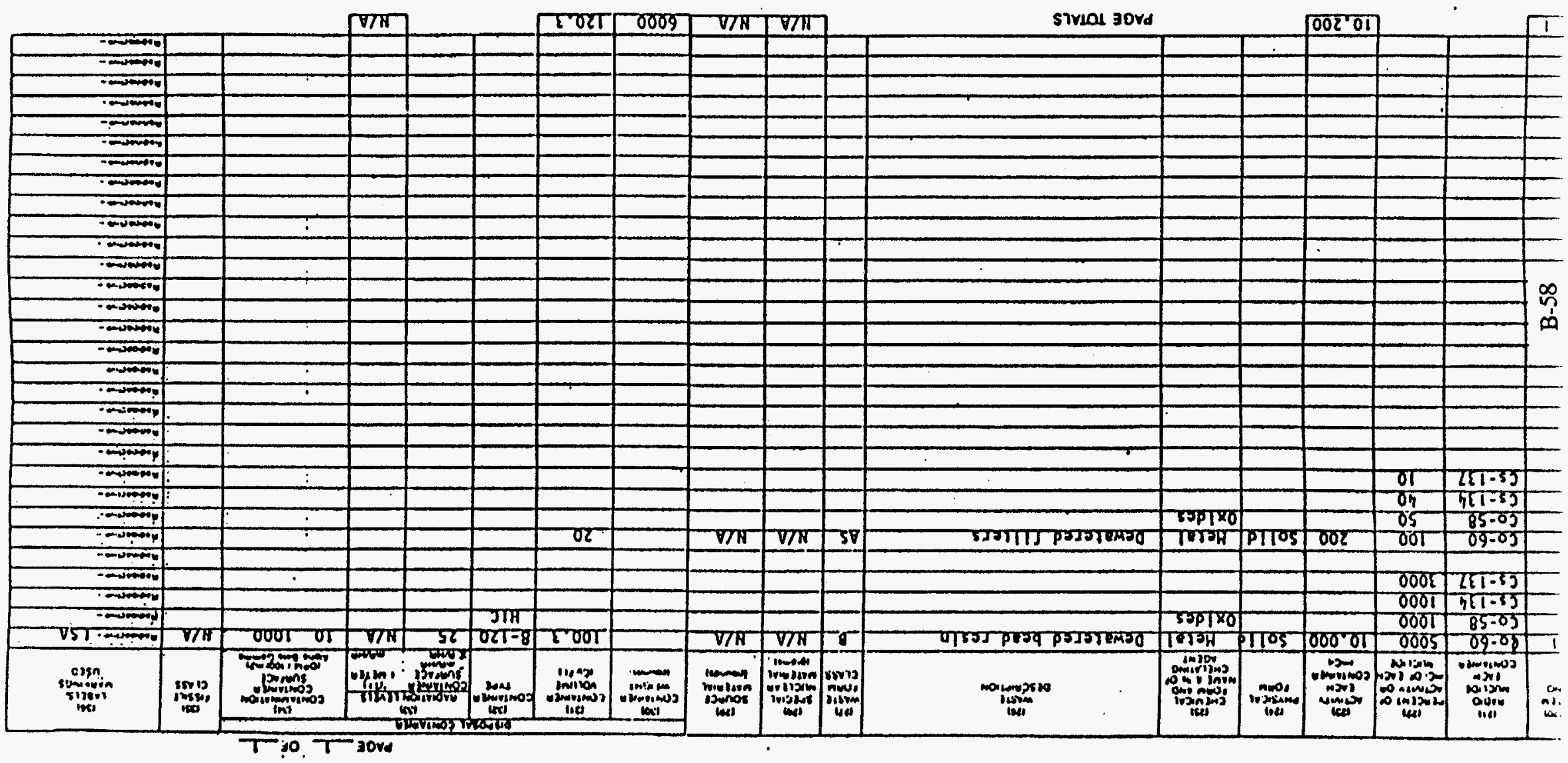

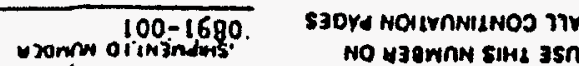

IJZHS NOIIYNNIINOJ

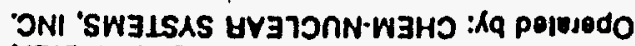

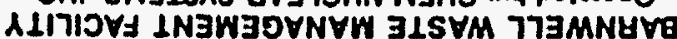


Papel of 26

\section{SOUTH CAROLIYA DEPARTMENT OF HEALTH A.ND ENIIRONMENTAL CONTROL}

\section{RADIOACTIV MATERIAL LICENSE}

Pursuant :o the Atomic Eaergy and Radiation Control Act Sec::on 13-i-20 et. seq. of S. C. Code of Laws of 19:6. as ameaded. and Supplenents the:eto, and the Soutb Carolina Deganment of Health and Environmental Control Regulation 61-6j. Radioactive. Material (Title $A$ ), and in reliance on statements and representacions beretolore aade by the a pplieane. a licerse is bereby issued authorizing the licensee to receive, acquire, possess and transfet radioactive axaterial listed below, and to use such radiozetive razterial for :he purpose(s) and at she place(s) designated below. This license is subject to all applicable rujes and regulatioas of the Sourb Carolina Depariment of Health and Environmental Control aow or hereafier in esteet and to any conditions specified below.

Anendinent in 45 amends

LICENSEE

1. Vame Chem-Nuclear Systems, Inc. Barnwell waste Management Facility

A Subsidiary of Waste Management, Inc.

2. Address

$$
\text { P.O. Box } 726
$$

Barnwell, S.C. 29812
3. License . Sumber

097 in its entirety.

4. Expiration Date

December 31, 1992
5. Radioactive Material (Element and Mass Number)

A. Any radioactive material excluding source material and special nuclear material.

B. Source material.

\section{Chemical and/or} Physical Form

A. Dry packaged radioactive waste except as authorized in this license.

B. Dry packaged radioactive waste except as authorized in this license.
7. Maximum Radioactivity

- andior quantity of maierial which licensee may possess at any one time.

A. 50,000 curies.

B. 60,000 pounds.

8. Authorized Use:

$A$ and $B$.

Radioactive material as low-level radioactive waste may be received, stored, and dispased of by shallow land burial. The licensee shall comply with all applicable terms and conditions of the southeast Interstate Low-Ievel Radioactive Waste Management compact and Section 5 of the Low-Level Radioactive Waste Policy Amendments Act of 1985 (P.L. 99-240), regarding volume limitations and allocation of disposal capacity; provided however, the licensee shall not receive an 


\section{Page 2 or 26 P2gs}

SOUTH CAROUNA DEPART.EEYT OF HEALTH A.VD E.YTROYMEYTAL CONTROL

Radioactive Material License

Supplementary Shees

License Yiumber $\frac{097}{45}$
Acend=ext Vo. $\quad 45$

annual volume of more than one million, two hundred thousand ( $1.2 \mathrm{million}$ ) cubic feet of waste per calendar year beginning January 1, 1986; however, the licensee is authorized to increase the volume in ten (10) per centur increments in accordance with the provisions of section 5 (a) (3) (b) of the Low-Level Radioactive Waste Policy Amendments Act of 1985; provided the Department is notified in writing no later than thirty (30) days in advance of such increases.

Unless otherwise authorized by the Department, only radioactive waste consigned for burial shall be received at the location specified in Condition No. 9 of this license. The maximum radioactivity and/or quantity of radioactive material indicated in Item 7. A and B applies only to above ground activities.

\section{General Conditions}

9. Unless otherwise specified, the authorized place of use is a site located approximately five miles northwest of Barnwell, South Carolina, in the Seven Pines School District, Red Oak Township, Barnwell county, South Carolina, within the boundary of the land area described in Lease Agreement dated April 6, 197.6, as amended.

10. The licensee shall comply with the provisions of Department Regulation 61-63, Radioactive Material, (Title A), Part I - General Provisions; Part II - Licensing of Radioactive Materials; Part III - standards for Protection Against Radiation; Part VI - Notices, Instructions, and Reports to workers; Inspections, and Part VII - Licensing Requirements for Land Disposal of Radioactive Waste; Department Regulation 61-83, Transportation of Radioactive Waste Into or Within South Carolina.

11. Operations authorized by this license shall be conducted in accordance with Chem-Nuclear systems, Inc. procedures and subsequent revisions and additions approved by the Department. However, the licensee may, upon notification to the Department but without Department approva?, make minor changes to these procedures provided that:

a. The change does not affect requirements of any other license condition in this license: 


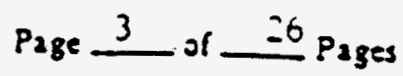

SOUTH CAROLNA DEPARTMEVT OF HEALTH AVD E.YHRONMENTAL CONTROL

Radioscive Mtacerial License

Suppleraentary Sheet

\begin{tabular}{ll} 
Lieense Number & 097 \\
Amend ment . .o. & 45 \\
\hline
\end{tabular}

General Conditions continued

b. The change does not increase the potential for personnel exposure;

c. The change does not diminish operational safety;

d. The change does not increase the potential for release of radioactive material to unrestricted areas; and

e. The change does not reduce the licensee's record keeping and reporting system.

The licensee shall maintain records of these changes including evaluations which provide the basis for the change.

12. Operations shall be conducted by or under the supervision of: John $\mathrm{S}$. Zawacki, Joseph J. Still, George Hurst, Michael T. Ryan (RPO), William B. House or other individuals designated by the licensee's Radiation Protection officer upon successful completion of the licensee's training program.

13. The licensee shall, to the extent necessary, continue the employment of all personnel involved in the operation of the Barnwell waste Management Facility in accordance with all reguirements of the license and applicable regulations and, in the event replacement of employees becomes necessary, only individuals of comparable qualifications and experience will be hired.

14. The licensee shall insure that all site personnel have satisfactorily completed the training program requirements as specified in the chemNuclear systems, Inc. Barnwell site Training Program. Changes and additions to the program shall be submitted to the Department for review. Time intervals for personnel indoctrination, training, examination, certification, retraining specified in standard operating Procedures S20-AD-004, "Barnwell Radioactive Waste Burial site Personnel Training" shall not be changed without Department approval.

15. A documented weekly inspection of site operations and the restricted area of the site for compliance with applicable conditions of this license shall be conducted by a named designee in Condition 12 . 


\section{SOUTH CAROLINA DEPARTMEYT OF HEALTH A.V EYVTRONMEYTAL CONTROL Radionctive Material License Suppletrentary Sbeet}

License viumber $\quad 097$

Aaendaent . Vo.

45

\section{General conditions Continued}

16. The transportation of radioactive materials and radioactive waste within the state of South Carolina shall be in accordance with applicable regulations of the U.S. Department of Transportation, the U.S. Nuclear Regulatory Commission, section RHA 2.22, Department Regulations 61-63, Radioactive Material, (Title A), and Department Regulation 61-83, "Transportation of Radioactive Waste Into or within South Carolina."

17. The licensee shall maintain all records and shipment manifests pertinent to the transportation, receipt, and disposal of radioactive material at the location specified in Condition 9 of this license until authorization is given by the Department for transfer of disposal of such records.

18. The licensee shall maintain a record for each shipment of waste disposed of at the site. As a.minimum, the record shall include:

a. the date of disposal of the waste;

b. the location of waste in the disposal site;

c. the condition of the waste packages received:

d. any discrepancy between the waste listed on the shipment manifest or shipping papers and the waste received in the shipment;

e. a description of any evidence of leaking or damaged packages or radiation or contamination in excess of applicable regulatory limits; and

f. a description of any repackaging operations of any of the waste packages in the shipment.

19. A monthly site receipt and burial activities report shall be submitted no later than the loth day of the following month to the Chief, Bureau of Radiological Health, S.C. Department of Health \& Environmental Control, 2600 Bull Street, Columbia, South Carolina 29201. 
Page 5 of 26 Pages

\section{SOUTH C.AROUNA DEPARTMENT OF HEALTH A.VD E.VVTRONMEYTAL CONTROL Radionerive Material License \\ Supplementer! Sbeet}

License Vumber

deendaent .io. 45

General Conditions Continued

20. Except as specifically provided otherwise by this license, the licensee shall possess and use radioactive material described in Items 5,6 , and 7 of this license and conduct site operations in accordance with statements, representations, operating procedures, and disposal criteria, heretofore made by the licensee or his authorized representative in application for and subsequent to issuance of S.C. Radioactive Material License No. 097, and amendments thereto.

21. Unless otherwise specified in this license, the licensee shall make no changes in the personnel training program, the internal safety audits, Safety Review Board, ALARA Review Committee, Site Criteria, or Procedures Manual and Standard operating Procedures, without approval from the Department.

\section{Receipt, Acceptance and Inspection Conditions}

22. The licensee shall not accept radioactive waste for storage or disposal unless the shipper has completed the required information for the waste shipment on a Barnwell waste Management Facility's Radioactive Shipment Manifest form or approved equivalent. Such form or revisions thereto shall be approved by the Department.

23. The licensee shall not accept radioactive waste for storage or disposal unless the shipper of such waste has a valid, unsuspended Radioactive Waste Transport Permit issued by the S.C. Department of Health ard Environmental Control.

24. The Iicensee shall not accept radioactive waste for storage or disposal unless the shipper has provided a properly executed Department Form, DHEC-803, Radioactive waste shipment Certification Form, Part I and II. For shipments consisting of more than 75 cubic feet or containing more than one (1) curie shall also be accompanied by a properly completed and executed Department Form, DHEC-802, Radioactive waste Shipment Prior Notification and Manifest Form.

25. The licensee shall only accept radioactive waste shipments for storage or disposal which have been inspected by a representative of the Department. 
Page of of $\rightarrow$ Pages

\section{SOUTH CAROUNA DEPARTMENT OF HEAITH A.VD ENITRONMEYTAL CONTROL Radioscive Material Lieense \\ Supplementery Steet}

\begin{tabular}{ll} 
License Number $\frac{097}{1}$ \\
deendment No. $\quad 45$ \\
\hline
\end{tabular}

26. Notwithstanding other conditions of this license, the licensee shall not accept radioactive waste for storage or disposal unless he has received advance written notification of any waste shipment containing unusual hazards or potential hazards including but not limited to, physical, gaseous, chemical, pyrophoric, or excessive removable contamination on disposal containers shipped inside casks or excessive internally contaminated casks, and unexpected high radiation levels at disposal container surfaces.

27. The licensee shall immediately notify the Department or the Department's on-site representative of any waste shipments where a violation of applicable regulations or license conditions has been found.

28. The licensee shall notify the shipper and the Department when any shipment of radioactive waste or part of a shipment has not arrived within 60 days after the advance copy of the shipment manifest or shipping papers was received by the Iicensee.

29. The licensee shall notify the shipper when it has been determined that a radioactive waste shipment or part of a shipment cannot be accepted for disposal by the licensee.

30. The licensee shall acknowledge receipt of the waste within 7 days of its acceptance for disposal by returning a signed copy of the shipment manifest or shipping papers to the shipper. The licensee shall indicate on the returned copy of the shipment manifest or shipping papers any discrepancy between waste descriptions listed on the manifest or papers and the waste materials received in the shipment.

\section{Waste Characteristics and waste Form conditions}

31. The licensee shall not accept any radioactive waste for storage or disposal unless the shipper has marked each package, as specified by the licensee, to identify its classification as either class A, stable or unstable, Class $B$, or class $C$ waste, and certifies that the waste materials have been classified and prepared for disposal in accordance with the following waste classification table: 


$$
\text { Page } 7 \text { of } 26 \text { Pages }
$$

SOUTH CAROLINA DEPARTMEYT OF HEALTH AVD EXVTRONMEYTAL CONTROL

Radioserive Mtaterial License

Supplementary Sheet

License Number

097

Aoendsent io

45

\section{Waste Classification Table}

\section{CONCENTRATION LIMITS IN CURIES/} CUBIC METER

RADIONUCLIDES

Table I (long-lived)

Class A Class B Class C

$c-14 \ldots \ldots \ldots \ldots \ldots \ldots \ldots \ldots$

C-14 in activated metal........

$\leq 0.8$

$\leq 8$

$\leq 22$

$\leq 0.02$

$\leq 0.3$

$\mathrm{Nb}-94$ in activated metal........

Tc-99.....................

$\leq 0.008$

$\leq 8$
$\leq 80$
$\leq 220$
$\leq 0.2$
$\leq 3$
$\leq 0.08$

CONCENTRATION LIMITS IN NANOCURIES/GRAMS

Ilpha emitting transuranics with nalf-life greater than 5 years... Pu-241..................... $\mathrm{Cm}-242 \ldots$

$\leq 10$

$\leq 350$

$\leq 2000$

$\leq 100$

$\leq 3500$ $\leq 20000$

Table II (short-lived)

Class $A$ Class B Class C

Total of all with half-life less

than 5 years................



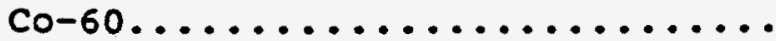

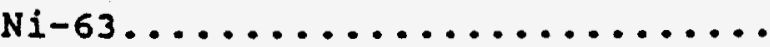

$\mathrm{Ni}-63$ in activated metal.......

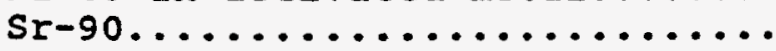

$c_{s-137 \ldots \ldots \ldots \ldots \ldots \ldots \ldots \ldots} \ldots \ldots \ldots \ldots$

* curies/cubic meter is equivalent to microcuries/cubic centimeters. 
Page 8 or 26 Pages

SOUTH CAROLINA DEPARTWEYT OF HEALTH A.VD EYYURONMEYTAL CONTROL Radionctive itateriel License Supplementary Sheet

License Number $\frac{097}{4}$
daendzenc Vio. $\quad 45$

Condition 31 . continued

a. The concentration of a radionuclide or radionuclide mixture may be averaged over the volume of the waste and, if used, the solidification agent or. matrix if the waste form is a homogeneous mixture. The concentration of radionuclides in filters/sealed sources encapsulated with a solidification agent or matrix shall be averaged over the volume of the filters/sealed sources not. the solidification agent. The volume of packaging, containers, liners or overpacks shall not be included in this calculation, nor shall the volume of the waste mixture be artificially increased by the addition of non-disperable solids or objects even if considered as waste.

- If expressed in units of nanocuries per gram, concentrations may be averaged over the weight of the waste and, if used, the solidification agent if homogeneous, except in the case of encapsulated filters which shall be over the weight of the filter. The weight of packaging containers, liners or overpacks shall not be included in this calculation, nor shall the weight of the waste mixture be artificially increased by the addition of heavy, non-disperable. solids or objects even if considered as waste.

b. The waste is class $A$ if none of the listed radionuclides are present. Radium waste as authorized by Condition 44 of this license shail be class $A$, stable or unstable.

c. There are no upper limits in Class B waste for the first three (3) radionuclides. Iisted in Table II.

d. There are no Class $B$ values for the first nine (9) radionuclides listed; their presence classifies the waste as either class $A$ or class $c$ according to their concentrations.

e. The waste class for mixtures of the Iisted radionuclides is determined by deriving for each radionuclide the ratio between its concentration in the rixture and its concentration limit in the table and adding the resulting ratio values for each radionuclide group. All limits used in the calculation must be for the same waste class. The sum of the ratios for each radionuclide group must be less than 1.0 or the waste is of a higher classification than that used for the calculation. 
Page $\stackrel{0}{2}$ or 26 Pages

SOUTH C.AROLINA DEPARTMEVT OF HEALTH A.VD E.VIRONMEYTAL CONTROL

Radioactive Material License

Supplementary Sheet

License Number

097

torend=ene tio.

45

f. If class $c$ limits are used in the calculation and the sum of ratios for either group is equal to or exceeds 1.0 , the waste is not acceptable for disposal without prior written approval from the Department.

g. If concentrations for any single radionuclide exceed the class $C$ values in the table, the waste is not acceptable for disposal without prior written approval from the Department.

32. A. Unless otherwise specified in this license, the licensee shall not receive any liquid radioactive waste regardless of the chemical or physical form. Absorbent materials may be placed in packages of dry, solid waste to absorb unintentional and incidental amounts of liquids. Further, liquids in the interstitial spaces of transport casks and containers shall be removed to the extent practical.

B. Solidified radioactive waste shall have no detectable free standing liquids in excess of one-half percent $(0.5 \%)$ by waste volume of non-corrosive liquids per container.

C. In lieu of the requirements of paragraph B. above, solidified waste containing non-corrosive liquids in excess of one-half percent $(0.5 \%)$ by waste volume, and less than one percent (1\%) noncorrosive liquids by waste volume, may be received and disposed of in high integrity containers approved by the Department.

33. A. Unless otherwise specified, the licensee shall only receive aqueous liquids and other applicable waste forms which have been solidified or otherwise stabilized with one of the following solidification media:

1. Vinyl Ester styrene

2. Cement

3. Bitumen (see Subparagraph E. below)

4. Vinyl Chloride

B. Solidification media and processes used to stabilize class A aqueous liquids and other applicable waste forms containing isotopes with greater than five (5) year half-lives having a total specific activity of all these isotopes of 1 microcurie/cubic centimeter or greater, and all applicable class $B$ and $C$ waste, shall meet and have been evaluated in accordance with the "Stability Guidance" requirements of the U.S. Nuclear Regulatory Commission's Low-Level Licensing Branch, Technical Position on 


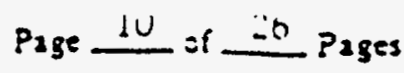

SOLTH C.AROLYA DEPARTMENT OF HEALTH AYD E.WTRONMENTAL CONTROL

Radioscrive Macerial License

Supplementary Sheet

License liumbe:

$\infty$

Aaeadmene Vio.

45

Waste Form, dated May 1983, or other evaluation criteria specifically approved by the NRC or the Department.

c. Solidified Class $\mathrm{A}$ aqueous 1 iquids and other applicable waste forms with a specific activity of less than 1 microcurie/cubic centimeter, shall meet the requirements of the "solidified class A Waste Products" of the NRC Branch Technical Position on Waste Forms, dated May 1983.

D. Other solidification media and processes shall be acceptable for which a topical report has been prepared and received approval from the U.S. Nuclear Regulatory Commission, and final approval by the Department.

E. The licensee shall only receive for disposal, full formula, oxidized bitumen (asphalt) solidified waste, and certified as such by the waste generator. Regardless of the waste classification; bitumen solidified waste received for disposal shall be a freestanding monolith and shall not demonstrate the characteristic of a free flowing, viscous fluid.

The licensee shall dispose of bitumen solidified waste in trenches commensurate with the applicable waste classification, and in all cases, provide sufficient backfill material to fill all voids around the waste to provide structural stability and minimize trench subsidence. The licensee may construct segregated trenches for disposal of bitumen waste provided approval is granted by the Department.

34. Except as specifically provided in this license, the licensee shall not accept 1 iquid radioactive waste packaged in absorbent materials, or where absorbent materials have been used to absorb liquids rather than properly solidified with an approved media.

35. Regardless of the waste classification of condition 31, and unless otherwise authorized by the Department, the licensee shall not receive evaporator bottoms or concentrates, residues, sludges, or other waste which may contain free standing liquids, unless they are solidified in accordance with condition 33 , and meet the requirements as specified in Condition 32 . 
Page 11 of 26 Pages

\section{SOUTH C.AROLINA DEP.ARTMEYT OF HEALTH A.V EYYTRONMEYTAL CONTROL Radioscaire Material License \\ Supplementar? Sheet}

License Numbe: 097

Aneadreat Yo. 45

36. The licensee may receive resins and filter media in a dewatered form provided that the free standing liquid requirements of condition 32 and the requirements of Condition 38 are met.

37. The licensee shall not receive containers of ion exchange resins or filter media (dewatered or solidified) unless records of complete radiological analyses (quantitative and qualitative) are provided. The records must specify the specific activity of each radionuclide expressed in microcuries/cubic centimeter and transuranic radionuclides in nanocuries/gram.

38. Regardless of the waste classification of condition 31, ion exchange resins and filter media containing isotopes with greater than five (5) year half-lives having a specific activity of all these isotopes of 1 microcurie/cubic centimeter or greater must be stabilized by solidification in accordance with Condition 33 and meet the free standing liquid requirements of condition 32.B. However, in lieu of solidification, the Department will authorize disposal of these waste forms meeting the free standing liquid requirements of condition $32 . c$. in approved high integrity containers or other approved methods of stabilization.

39. A. The licensee shall not receive solidified class A waste containing isotopes with greater than five (5) year half-lives having a totally specific activity of all these isotopes of 1 microcurie/ cubic centimeter, and Class $B$ and $C$ waste, unless it is structurally stable and provides reasonable assurance that the waste will maintain its general physical dimensions and its form under the expected disposal condition, which include the weight of soil overburden and compaction equipment, the presence in the burial environment of moisture and microbial activity, and factors internal to the waste itself such as radiation effects and chemical changes.

B. Structural stability can be provided by the waste form itself if it is a solid monolith, processing the waste to a stable form or placing the waste in a high integrity container that provides stability after disposal. Such containers shall have prior approval of the Department. Polyethylene high integrity containers which serve to provide stability for Class $B$ and $C$ wastes must additionally be placed in a Departmentally approved concrete overpack, which are to be provided by the site operator. 


\section{SOUTH C.AROLIA DEPARTMEYT OF HEALTH A.ND ENYTRONMEYIAL CONTROL Radiosctive Material License Supplementery Sheet}

License Sumber

deend =ere Vo.
097

45

c. Void spaces within the waste and between the waste and its packaging shall be reduced to the extent practicable, but in no case shall less than eighty-five percent (85\%) of the capacity of the containers be filled for Class A Stable, Class B and Class C waste unless placed in a High Integrity Container or in a concrete overpack. The licensee may allow a variance from this condition in certain instances, but only after receiving a written justification from the waste generator prior to receiving the waste shipment. Variance justifications and approvals shall be maintained for review by the Department.

40. Except as specified in the waste classification table of Condition 31 of this license, the licensee shall not receive waste containing any transuranic radionuclides. Radioactive waste containing transuranic radionuclides specified in Condition 31 are acceptable provided that the transuranic radionuclides are evenly distributed within a homogeneous waste form and are incidental to the total radioactivity. This license does not authorize the receipt of disposal of components or equipment primarily contaminated with transuranic radionuclides. on vehicles, equipment, or components, with contamination limits in excess of those specified in condition 55 in. a controlled environment.

41. Household or industrial smoke or gas detectors containing Americium-24I foils which may exceed the transuranic radionuclide limit specified in Condition 31 of this license may be accepted for disposal provided the entire detector is received for disposal.

42. The licerisee shall not receive or dispose of sealed sources or special form radioactive materials containing more than 5 curies of radioactive material with half-lives greater than 5 years except in a container which provides long term containment. such containers are subject to approal by the Department. Irradiated metal components which have similar characteristics of special form radioactive materials are subject to Department review for disposal container requirements.

43. The licensee shall not receive toluene, xylene, dioxane, scintillation liquids which exhibit hazardous properties or other organic liquids or solids with similar chemical properties or containers which have at any time contained any of the liquids mentioned above. However, after complete incineration, the ash and/or residue from these wastes are acceptable not withstanding the requirements of Condition 45 of this iicense, unless otherwise authorized by the Department. 
Page 13 of 26 Pages

\section{SOUTH C.AROUNA DEPARTMEYT OF HEALTH A.ND E.YYTRONMEVIAL CO.VTROL Radionctive Material License \\ Suppleroentary Sheet}

Licerse Vumber

dareadrear io.

45

44. Unless otherwise authorized by the Department the licensee shall not receive any radioactive waste containing Radium except for:

a. Radium contained in solid homogeneous waste forms in which the Radium activity is incidental to the total activity and the concentration of Radium has not been technologically enhanced or,

b. Radium contained in the following devices: self-luminous dials, hands of dials, timepieces, compasses, and electron tubes provided that the entire device is received and buried, or

c. Radium contained in biological research waste.

45. The licensee shall not receive radioactive waste in the forms of incinerator ash or powder which may be dispersable unless solidified with a media specified in Condition 33 of this license, or packaged to prevent dispersion as specifically approved by the Department. In lieu of solidification, these waste forms may be received in high integrity containers approved by the Department, provided the waste is stabilized with a binding matrix.

46. The licensee shall not receive waste containing chelating agents with concentrations greater than 8 percent by weight. Radioactive waste containing chelating agents within the range of 0.1 to 8 percent by weight shall not be accepted by the licensee unless stabilized by solidification with a media specified in Condition 33 of this license. The concentration limits apply to wastes prior to solidification: dilution'by solidification media is not allowable. Wastes containing chelating agents shall be segregated from $C$ lass $B$ and $C$ wastes by at least ten (10) feet in the all directions in the burial trench. Use of a Departmental approved concrete overpack constitutes adequate separation.

47. The licensee may only receive gaseous radioactive materials of Krypton 85 and Xenon 133 for burial provided they meet the following criteria:

a. Burial containers must be U.S. Department of Transportation specification cylinders or U.S. Nuclear Regulatory Commission approved sealed sources.

b. Internal pressure of containers may not exceed 1.5 atmospheres.

c. - Total activity of containers shall not exceed 100 curies each. 
Page th of -is Pages

SOLTH CAROLNA DEPARTMENT OF HEALTH A.D ENITRONMENTAL CONTROL Radionctive Material License Supplementerg Sheet

\begin{tabular}{ll} 
License Number & 097 \\
Acend.enent Vo. & 45 \\
\hline
\end{tabular}

48. A. Unless otherwise authorized, the licensee shall not receive for storage nor disposal any mixed low-level radioactive waste defined as waste that satisfies the definition of low-level radioactive waste specified in the Low-Level Radioactive Waste Policy Amendments Act of 1985 (P.L. 99-240), and contains waste that either (1) is listed as hazardous waste in subpart D, 40 CFR 261, or (2) causes the waste to exhibit any of the hazardous waste characteristics indentified in subpart C, 40 CFR Part 261.

B. The licensee may however receive waste that has been treated by acceptable methods to render it nonhazardous and therefore not subject to the jurisdiction of the Resource Conservation and Recovery Act (RCRA). Waste which may contain discrete quantities of hazardous or toxic materials may be evaluzted for disposal by the licensee and such evaluations provided to the Department for consideration of approval.

9. The licensee shall not receive radioactive waste that is readily capable of detonation or of explosive decomposition or reaction at normal pressures and temperature, or of explosive or exothermic reaction with water.

50. The licensee. shall not receive radioactive waste which contains or is capable of generating quantities of toxic gases, vapors, or fumes harmful to persons transporting, handling or disposing of the waste. This does not apply to radioactive gaseous waste packaged in accordance with Condition 47 of this license.

51. The Iicensee shall not receive or dispose of any pyrophoric material or flammable solids. These materials contained in wastes shall be treated, prepared and packaged to be nonflammable and the final waste form rendered nonpyrophoric and nonflammable prior to transportation and receipt.

52. The licensee shall not receive or bury oil or petroleum based materials in any physical form. However, this does not prohibit the receipt and disposal of waste containing incidental or trace amounts of oil or petroleum based materials which have been absorbed, provided - that the amount of absorbed oil and petroleum based materials does not exceed one percent (1\%) by waste volume in a container. 
Page LI of $=0$ Pages

SOLTH CAROLINA DEPARTMEYT OF HEALTH A.YD ENITRONMEYTAL COYTROL

Radioactive Macerial License

Suppieraentar: Sbeet

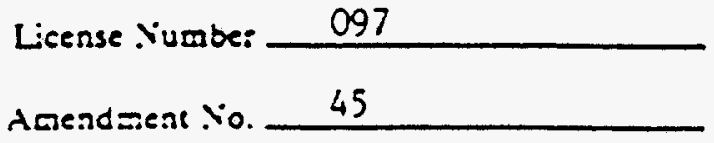

53. The licensee shall not receive radiaoctive waste containing hazardous biological, pathogenic, or infectious material unless treated to reduce to maximum extent practicable the potential hazard from the materials. In addition, radioactive waste containing biological, pathogenic, or infectious material shall be doubly packaged in new or properly recertified 17-H DOT specification containers or equivalent as follows:

a. First, the inner container having a capacity of 55-gallon or less shall have a water tight liner at least $4 \mathrm{mils}$ thick hermetically sealed after filling.

b. The biological material shall be throughly layered in the inner container in a ratio of thirty (30) parts biological material to

- at least one (1) part slaked lime and ten (10) parts absorbent, which shall be agricultural grade 4 vermiculite or medium grade diatomaceous earth, by volume. The addition of formaldehyde is strictly prohibited.

c. The closure on the inner container shall be made with a 16-lug closing tool or standard lid with securely attached ring and bolt. Lever locks are not acceptable.

d. The outer container, 55-galion capacity for a 30-gallon inner container, or 83-gailon capacity for a 55-gallon inner container, shall be filled initially with at least 4 inches of absorbent mateial, specified in b., the inner container in an upright position, and the remaining volume filled with the absorbent material; then securely closed and properly sealed.

e. Containers of small capacity may be used provided that the volume of the outer container is at least 1.5 times the volume of the inner container.

\section{Contamination Limit conditions}

54. For receipt at the Barnwell site, all shipments shall comply with contamination control limits as prescribed in U.S. Department of Transportation Regulations, 49 CFR 173.443. 
Page + of of Pages

SOUTH C.AROLINA DEPARTMEYT OF HEALTH A.YD EYVTRONMEYTAL CONTROL

Radioacrive Material License

Supplementary Sbeet

\begin{tabular}{l} 
License Number $\frac{097}{}$ \\
denendzent . .o. $\quad 45$ \\
\hline
\end{tabular}

Enclosed radiaoctive material transport vehicles used solely for transporting radioactive materials and marked "For Radioactive Material Use Only" and accessible surface of transport casks and trailers shall not be released from the site if contamination limits exceed the following:

a. Fixed contamination of $10 \mathrm{mR} / \mathrm{hr}$ on contact with the interior surface or $2 \mathrm{mR} / \mathrm{hr}$ at 1 meter from the interior surface.

b. Removable contamination of $2200 \mathrm{dpm} / 100 \mathrm{sq}$. cm. Beta-gamma or 220 $\mathrm{dpm} / 100 \mathrm{sq} \cdot \mathrm{cm}$. Alpha. This applies to interior and exterior surfaces.

c. Fixed contamination of $0.5 \mathrm{mR} / \mathrm{hr}$ on contact with any exterior surface.

Internally contaminated (fixed or removable) shipping casks released from the site are subject to applicable shipping regualtions of the U.D. Department of Transportation. The licensee shall also inform the recipient of such casks in advance of the contaminated nature of the cask. Records of such notifications shall be retained for review by the Department.

55. Vehicles used solely for transporting radioactive material and are not marked "For Radioactive Material Use only" shall not be released from the site if the contamination Iimits exceed the following:

a. Fixed contamination of $0.5 \mathrm{mR} / \mathrm{hr}$ at any accessible surface.

b. Removalbe contamination of 2200 dpm/100sq. cm. Beta-gamma, or 220 $\mathrm{dpm} / 100 \mathrm{sq}$. cm. Alpha.

56. Vehicles or items for unrestricted use shall not be released from the site if the contamination limits exceed the following:

a. Fixed contamination of $0.1 \mathrm{mR} / \mathrm{hr}$ at any accessible surface.

b. Removable contamination of $220 \mathrm{dpm} / 100 \mathrm{sq}$. cm. Beta-gamma, or 22 dpm/100sq. cm. Alpha.

57. The licensee shall perform sandblasting for decontamination purposes on vehicles, equipment, or components, with contamination limits in excess of those specified in condition 55 in a controlled environment. 
SOLTH CAROUNA DEPARTMENT OF HEALTH A.VD E.WTRONMENTAL CONTROL

Radioacrive Mlaterial License

Supplerientary Sbeet

License Numbe: $\frac{097}{45}$
desend-neart .Oo. 4

58. The licensee shall not use its vehicle wash-down facility for any vehicles or equipment with removable contamination limits in excess of those specified in condition 55 unless specifically approved by the Department.

\section{General Packaging conditions}

59. All radioactive waste shall be packaged and loaded in accordance with applicable U.S. Department of Transportation Regulations, U.S. Nuclear Regulatory Commission Regulations $10 \mathrm{CFR}$ Part 71 , the requirements of this license, and the disposal site criteria.

60. Unless otherwise authorized, all radioactive waste shall be received and buried in closed containers. Containers which have been altered, and solidification or encapsulation media intended to serve as containers or container closures, are not acceptable unless approved by the Department. Loose radioactive waste and solidification residuals within shipping casks are prohibited.

61. The licensee shall not receive any package to be used as the final burial container that is corroded to the point of degradation or damaged. Any package used as the final burial container shall be of such material and construction that there will be no significant chemical, galvanic, or other reaction among the packaging components, or between the packaging components and the package contents.

62. The licensee shall, to the extent practicable, repair or repackage any damaged package used as the final burial container if such packages are approved for acceptance by the Department.

63. Prior to burial, the licensee shall, to the extent practicable, remove all liquids from waste packages found in excess of allowable limits if such packages are approved for acceptance by the Department.

64. The licensee shall not receive shipments of radioactive materials unless appropriate lifting devices of sufficient length have been provided and securely attached to containers and palletized shipments within a cask. 
Page 16 of 20 Pages

SOUTH C.AROUNA DEPARTMEYT OF HEALTH A.TD E.TVRONMENTAL CONTROL

Radioncrive Material Lietrse

Supplementery Sheet

License Vumber

097

doeadzent Yo.

45

65. The licensee is not authorized to open any packages at its facility, except for the following:
a. For purposes of repairing or repackaging damaged containers.
b. For purposes of inspecting to insure compliance with this license.
c. For purposes of returning outer shipping containers.
d. For purposes of confirming package contents.

\section{site Design, Construction and Maintenarice Conditions}

66. Construction of waste burial trenches shall be in accordance with CNSI Procedure S20-AD-008, "Trench Construction" Class A waste trenches will be constructed in accordance with Drawing No. B-215-D-004, "Class A Trench Construction Details." Class $B / C$ waste trenches will be constructed in accordance with Drawing No. B-215-D-007, "Class B/C Trench Construction Details." Any changes to these drawings, specifications, or procedures must have approval from the Department before implementation.

67. The licensee shall not begin construction of any trench prior to approval of the Department as to location, trench bottom elevation and intended use.

68. The licensee shall not initiate burial operations in newly excavated trenches until the Department has inspected and approved the trenches. An initial inspection will be made by the Department upon completion of excavation of the trench, sumps, french drain inside the trench, drainage ditches adjacent to the trench and installation of sumps and standpipes. An intermediate inspection will be made by the Department after the french drain and sumps have been filled. A final

inspection will be made by the Department upon completion of construction. Trench backfill and completion shall be performed in accordance with CNSI Procedure S20-AD-008, "Trench Construction."

69. Construction of slit trenches shall be in accordance with CNSI Drawing No. B-215-D-0011, "Sli.t Trench Construction Details." Trench backfill and completion shall be performed in accordance with CNSI Procedure S20-AD-008, Trench construction. An initial inspection shall be made by the Department at the completion of excavation, and final inspection shall be made at the completion of construction before burial begins. 
Page 19 or 26 Pages

SOLTH CAROLNA DEPARTMEVT OF HEALTH AND E.YTRONMENTAL CONTROL

Radioactive Mtaterial License

Supplementery Sheet

Leense Number 097
Aeend-nent Vo. 45

70. A. Backfilling shall be performed for each trench design in accordance with CNSI Procedure S20-AD-008. Completed trenches shall at no time be used for stockpiling large volumes of earth not withstanding provisions for a final grading plan.

B. The licensee shall design trench covers to minimize to the extent practicable water infiltration, to direct percolating or surface water away from the disposed waste, and to resist degradation by surface geologic processes and biotic activity.

71. Open trenches to include trenches under construction and partially filled trenches shall be protected to prevent runoff water from entering trenches. Radioactive waste shall not be placed into trench areas where water has accumulated. Burial of radioactive waste into trenches with unusual amounts of water shall immediately cease until the origin of water has been determined and corrective action taken.

72. The licensee shall use proper surface water management techniques on the site to insure that:
a. Erosion is minimized.
b. Surface runoff is directed away from the trenches.
c. Accumulation of standing water is minimized.
d. Standing water in the immediate disposal area is prevented.

73. All monitoring wells, sumps, disposal tubes, and protrusions into the trenches, shall be sufficiently capped or covered to prevent the introduction of extraneous material or infiltration of water. All well and sump pipes shall be protected from damage.

74. The licensee shall, at least monthly, perform an inspection of completed trenches to ascertain any erosion, settling, cracking, subsidence, or loss of ground cover grasses and make corrections immediately. Documentation of the inspection findings and all repairs even if the repairs were performed as a routine maintenance function shall be made and incorporated into a permanent record and submitted with the stabilization plan for final site closure. 


\section{SOUTH CAROLINA DEPARTMEYT OF HEALTH A.V E.NTRONMENTAL CONTROL Radioactive .Interial License Supplementary Sheet}

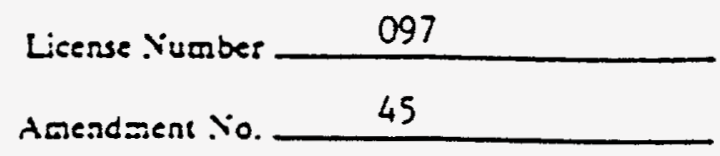

75. The licensee shall initiate closure and stabilization measures as each trench is filled and covered. Interim or final grades shall be established and seeding of trench covers shall commence at no more than one year following final trench burial operations. Active waste disposal operations must not have an adverse effect on completed closure and stabilization measures.

76. The licensee shall use any reasonable means, including but not limited to fencing and security personnel, to prevent unauthorized entry into the restricted area of the site.

77. The boundaries and locations of each disposal trench shall be accurately located and mapped by means of a land survey... Temporary trench boundary markers and trench identification markers shall be erected upon completion of backfill operations until permanent markers are installed.

78. A series of markers, one at the end of each completed trench and on each corner, shall be installed upon completion of the seeding of trench covers. End monuments shall be constructed of granite. Trench corner markers shall be constructed in accordance with CNSI Drawing No. B-215-C-0010. The following information shall be inscribed on the end monument, and this information shall be reportied to the chief, Bureau of Radiological Health, S.C. Department of Health and Environmental Control, 2600 Bull street, Columbia, S.C. 29201:

a. Total activity of radioactive material in curies total amount of source material in pounds, and total amount of special nuclear material in grams in the trench.

b. Date of completion of the burial operations; and

c. Volume of waste in the trench.

\section{Burial Operation Conditions}

79. Unless specifically authorized by the Department, the licensee shall not exhume previously buried waste. 
SOUTH C.AROUIA DEPARTMENT OF HEALTH AVD E.VZRONMEYTAL CONTROL Radiostive Material License Supplementary Sbeet

License Vumber 097

taendment io. 45

80. Wastes designated as Class $A$, unstable, pursuant to condition 31 of this license, and solidification Class $A$ waste which do not meet the stability requirements of condition $33 . \mathrm{B}$., must be segregated from other wastes by placing in a separate disposal trench or by other methods specifically approved by the Department which will minimize trench subsidence and achieve long-term stability to eliminate ongoing active site maintenance.

81. Wastes designated as class $C$ pursuant to Condition 31 of this license, shall be disposed of so that the top of the waste is a minimum of 5 meters below the top surface of the cover or shall be disposed of with intruder barriers that are designed to protect against an inadvertent intrusion for at least 500 years. Such intruder barrier designs must be specifically approved by the Department.

82. The licensee shall handie and emplace packages of radioactive waste in disposal trenches in such a manner that maintains packaging integrity during handling, emplacing, and subsequent backfiliing. Waste packages deposited in trenches shall be protected from any adverse operations which may cause damage to them.

83. The licensee shall emplace radioactive waste packages in such a manner to minimize voids between packages and permits voids between packages to be filled with earth to reduce future trench subsidence.

84. Licensee personnel shall wear appropriate protective clothing, apparatus, and gloves at all times while handling or disposing of radioactive waste.

85. The licensee shail be a "Registered User" of all licensed casks delivered to the site containing radioactive waste for disposal.

86. At least one health physics technician shall be present during all waste handling, offloading and disposal operations.

87. The licensee shall maintain radiation levels at the edge of open trenches at or below $100 \mathrm{mR} / \mathrm{hr}$.

88. Uncovered waste shall not extend more than $100 \mathrm{ft}$. beyond the backfilled portion of the trench. 
SOLTH CAROLINA DEPARTMEYT OF HEALTH A.VD ENWRONMENTAL CONTROL Radionctive Maserial License

Supplerentery Sheet

License Number 007

daendrent io. 45

89. The 1 icensee shall bury containers of Krypton 85 and Xenon 133 gaseous radioactive materials in upright positions in the trench with a minimum spacing of ten (10) ft. between gas containers.

90. Unless specifically authorized, the licensee shall not store any package containing radioactive waste for a period greater than six months from the date of receipt of the package prior to burial. Radioactive waste shall not be stored in the trench area or an open environment for a period greater than ten (10) days from receipt, and shall be protected from damage and inclement weather conditions.

91. Deleted

\section{Environmental surveillance conditions}

92. The 1icensee shall conduct an on-site monitoring and environmental monitoring program capable of detecting the potential contribution of radioactive material and hazardous constituents from the site to the environment. The monitoring program shall be performed in accordance with CNSI procedures - Barnwell site.

93. Should any samples taken from the monitoring wells, or air samples reveal increases in the concentration of radioactive material which were determined prior to commencement of the burial operations, the licensee shall perform further surveys to determine whether or not the increase is due to the land burial operations. The licensee shall notify the Chief, Bureau of Radiological Health, S.C. Department of Health and Environmental Control, within 48 hours of any such increases.

94. The licensee shall submit results of all scheduled environmental sampling and analysis to the Department quarterly.

95. Monitoring wells in clusters will be placed outside the trenches but in the trench area. Specific locations shall be determined through consultation. The initial well of a cluster will be core drilled to the water table and a representative sample of the core shall be submitted to the Department. The depth and number of additional wells in the cluster are to be determined by the geotehnical observations in the initial core. All wells shall be grouted, sealed and capped. 
Page 23 of 25 Pages

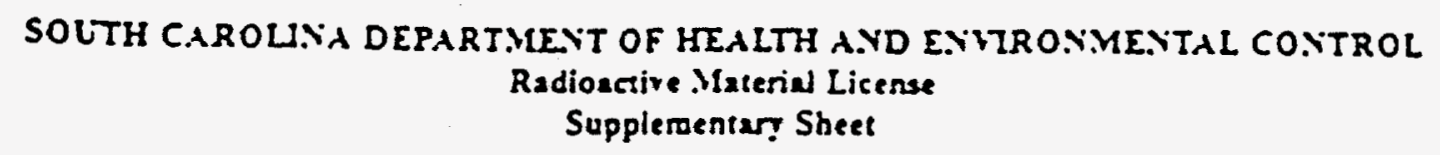

License Yumber $\infty$

dmendrent tio. 45

\section{Site clósure \& stabilization conditions}

96. As radioactive material buried may not be transferred by abandonment or otherwise, unless specifically authorized by the Department, the expiration date of this license applies only to the above ground activities and to authority to bury radioactive material wastes at the site specified in condition 9. The license continues in effect and the responsibility and authority for possession of buried radioactive material wastes continues until the Department finds that the plan established for preparation of the Barnwell site for transfer to another person has been satisfactorily implemented in a manner to reasonably assure protection of the public health and safety and the Department takes action to terminate the licensee's responsibility and authority under this license. All requirements for environmental monitoring, site inspection, maintenance and site security continue whether wastes are being buried or not.

97. The licensee shall develop a site closure and stabilization plan that addresses, as a minimum, the following performance objectives:

a. Bury all waste in accordance with the requirements of the license.

b. Dismantle, decontaminate, as required, and dispose of all structures, equipment, and materials that are not to be transferred to the site custodian.

c. Document the arrangements and the status of the arrangements for orderly transfer of site control and for long term care by the government custodian. Also document the agreement, if any, of state or federal governments to participate in, or accomplish, any performance objective. Specific funding arrangements to assure the availability of funds to complete the site closure and stabilization plan must be made.

d. Direct gamma radiation from buried wastes should be essentially background.

e. Demonstrate by measurement and/or model during operations and after site closure that concentrations of radioactive material which may be released to the general environment in ground water, surface water, air, soil, plants, or animals will not result in an annual dose exceeding an equivalent of 25 millirems to the whole body, $75 \mathrm{millirems}$ to the thyroid, and $25 \mathrm{millirems}$ to any other organ of any member of the public. 
SOLTH CAROLIA DEPARTMEYT OF HEALTH A.D E.TIRONMEITAL CONTROL

Radioactive Material License

Supplementary Sheet

Lieense Number $\frac{007}{0}$

Aaend-reas Vio. $\frac{45}{4}$

f. Render the site suitable for surface activities during custodial care. Planned custodial care may be limited to activities such as vegetation control, minor maintenance, and environmental

monitoring. However, use of the site surface for activities such

as parking lots may be planned. Final conditions at the site must be acceptable to the government custodian and compatible with its plan for the site.

9. Demonstrate that all trench elevations are above water table levels taking into account the complete history of seasonable fluctuations.

h. Eliminate the potential for erosion or loss of site or trench integrity due to factors such as groundwater, surface water, wind, - subsidence, and frost action. For example, an overall site surface water management system must be established for humid sites to drain rainwater and snowmelt away from the burial trenches. All slopes must be sufficiently gentle to prevent slumping or gullying. The surface must be stabilized with established short rooted grass, rock, riprap, or other measures. Trench caps must be stabilized to minimize erosion, settling, or slumping of caps.

i. Demonstrate that trench markers are in place, stable, and keyed to benchmarks. Identifying information must be clearly and permanently marked.

j. Compile and transfer to the Department complete records of site maintenance and stabilization activities, trench elevation and locations, trench inventories, and monitoring data for use during custodial care for unexpected corrective measures and data interpretation.

k. Establish a buffer zone surrounding the site sufficient to provide space to stabilize slopes, incorporate surface water management features, assure that future excavation on adjoining areas would not compromise trench or site integrity, and provide working space for unexpected mitigating measures in the future. The buffer zone must also be transferred to the custodial agency. The buffer zone may generally be less than 300 feet but not less than 100 feet. 
Page 25 of $=6$ Pages

SOLTH CAROUNA DEPARTMEVT OF HEALTH A.YD E.YLTRONMENTAL CO.YTROL

Radionctive Material License

Supplementary Sheet

License Number

097

Aøendment lio.

45

1. Provide a secure.passive site security system (e.g., a fence) that requires minimum maintenance.

m. Stabilize the site in a manner to minimize environmental monitoring requirements for the long-term custodial phase and develop a monitoring program based on the stabilization plan.

n. Investigate the causes of any statistical increases in environmental samples which have occurred during operation and

stabilization. In particular, any evidence of unusual or unexpected rates or levels of radionuclide or hazardous constituent migration in or with the groundwater must be analyzed and corrective measures implemented.

o. Eliminate the need for active water management measures, such as sump or trench pumping and treatment of the water to assure that wastes are not leached by standing water in the trenches.

p. Evaluate present and zoned activities on adjoining areas to determine their impact on the long-term performances of the site and take reasonable action to minimize the effects.

98. A preliminary plan for preparation of the site for transfer to another person who would only passively hold the site shall be submitted for review. The plan shall be consistent with condition 97 of this license and shall include demonstration that funds are being set aside or other measures being taken are adequate to finance the site closure plan. The plan shall also include preliminary estimates of costs, environmental impacts, data needs, personnel needs, material and equipment needs, planned documentation and quality assurance, and detailed plan for trench locations and elevations, expected capacities, planned surface contours, and buffer zones.

99. A reassessment of current operating practices shall be submitted. The reassessment shall consider the objectives of the site plan specified in condition 98 and any changes in operation at the site which would enchance implementation of the plan.

100. The licensee shall submit an updated plan and operational assessment every five (5) years for review. 
SOUTH CAROLINA DEPARTNEYT OF HEALTH AND ENVIRONMENTAL CONTROL

Radioactive Material License

Supplementary Sheet

Lisease Number 097

Ameodmeat No. 45

101. One (1) year prior to the anticipated transfer of the site and buried radioactive materials to another person (including an agency of the U.S. Government) the licensee shall submit a final version of the site preparation. plan including a scheduie for implementation of all remaining elements prior to transfer, and a description of the mechanics of orderly transfer in coordination with the transferee.

Dace of Issuance Ianuary i, 2000
For The Soush Carolina Deparment

of Health ind Enviconmeneal Consrol

B-84

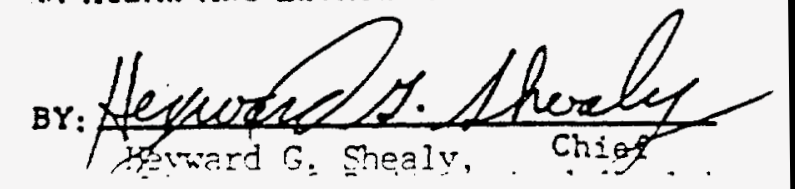




\section{RADIOACTIVE MATERIAL LICENSE}

Pursuant to Nevada Revised Statute 459.040 and State of Nevada Regulation for Radiation Control and in reliance on statements and representations heretolore made by the licensee designated below, a license is hereby issued authorizing such licensee to transfer, receive, possess and use the radioactive material designated below; and to use such radioactive material for the purpose(s) and at the place(s) designated below. This license is subject to all applicable rules, regulations, and orders now or hereafter in effect and to any conditions specified below.

\begin{tabular}{|c|c|}
\hline $\begin{array}{l}\text { LICENSEE } \\
\text { Iogy, InC. }\end{array}$ & $\begin{array}{l}\text { 3. License number: } \\
13-11-0043-02\end{array}$ \\
\hline $\begin{array}{l}\text { 2. Address: P.O. Box } 7246 \\
\text { Louisville, KY } 40207\end{array}$ & $\begin{array}{l}\text { 4. Expiration date: } \\
\text { December 31, } 1992\end{array}$ \\
\hline & $\begin{array}{l}\text { 5. Amendment No. } 13 \text { amends the 11cense in } \\
\text { Its entirety. }\end{array}$ \\
\hline
\end{tabular}

6. Radioastive material:

(Element and mass number)

A. Any radicactive material excluding source material and special nuclear material.

B. Source material.

C. Special nuclear material.

D. Any radicactive material excluding special nuclear material.
7. Chemical and/or physical form:

A. Dry packaged radioactive waste except as

B. Dry packaged radicactive waste except as authorized in this license.

C. Dry packaged radioactive waste except as authorized in this license. authorized in this license.

8. Maximum quantity licensee may possess at any one time:

A. 60,000 curies.

B. 36,000 kilograms

C. 200 grams of Uranium 233 , 350 grams of Uranium 235, 200 grans of Plutonium, or any combination of these as long as the following formula is not exceeded: $\frac{\text { gms U-233 }}{200}+\frac{U-235}{350}+\frac{\text { gms Pu }}{200} \leq 1$

Plutonium may not be received in concentrations exceeding those indicated in Table 1 of NAC 459.827

D. Any.

D. 0.1 curie. 


$$
\text { Page...2......or.......... Pazes }
$$

NEYADA STATE HEALTH DIVISION.

\section{RADIOACTIVE MATERIAL LICENSE SUPPLEMENTARY SHEET}

License Number. 13-11-0043-02

\section{CONDITIONS}

9. Authorized use:

A., B. and C.

Radioactive waste may be received, transferred, stored, repackaged and disposed of by shallow land burial. The maximum radioactivity or quantity of radioactive material indicated in Item $8 . A, B$, and $C$ applies only to above ground activities.

D. Calibration or check sources.

10. The authorized place of disposal is the state-owned radioactive waste disposal area located in Nye County, Nevada, and only within the boundries as described below:

NW 1/4 NE 1/4; NE 1/4 NW 1/4 of Section 35 ,

Township 13 South, Range 47 East,

Mount Diablo Baseline and Meridian

11. Reference to the "Division" in this license shall mean the Nevada Division of Health.

12. The licensee shall notify the Division in writing within 30 days of the appointment of a new Facility Manager, Facility Assistant Manager, and Corporate or Facility Radiological Control and safety officer, describing how the appointee meets or exceeds the minimum qualifications specified in the Facility standards Manual.

13. Upon receipt of a shipment of radioactive waste the licensee shall send to the Division by telefax, a copy of the first page of the manifest, and in the case of a broker's shipment shall also send the Manifest Index and Regional Compact Tabulation. Starting in April of 1990 a new type of monthly facility receipt and burial activities report shall be submitted no later than the 15 th day of the following month to the ILW Project Manager. The report shall include as a minimum the following information for each shipment: 


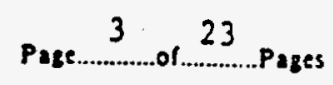

NEVADA STATE hEALTH DIVISION.

RADIOACTIVE MATERIAL LICENSE

SUPPLEMENTARY SHEET

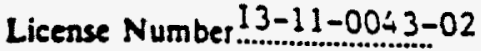

\section{CONDITIONS}

13. (continued)

a. Name and address of the generator(s); broker (if any); and shipper;

b. Radionuclides and activity of each radionuclide in millicuries (total and by generator):

c. Grams of special nuclear material (total and by generator);

d. Mass (in kilograms) of source material received (total and by generator):

e. Class totals of volune and activity of Class $A, B$, and $C$ waste entrenched (total and by generator); and to the extent practicabie;

f. Type and physical form of the waste, and

9. Chemical forms of the waste and stabilization, solidification or sorption agent.

\section{GENERAL PACKAGING CONDITIONS}

24. All radioactive waste shall be packaged, loaded, received and transported in accordance with all applicable U.S. Department of Transportation Regulations and Chapter 459 of NAC.

15. Unless specifically authorized by the Division, all radioactive waste shall be received and buried in closed containers. Cardboard corrugated paper and fiberboard are prohibited burial containers. Unless specifically authorized by the Division, radicactive waste in wooden outer containers shall not be received for disposal.

Dase 


$$
\text { Page............of............Pages }
$$

NEVADA STATE HEALTH DIVISION.

\section{RADIOACTIVE MATERIAL LICENSE SUPPLEMENTARY SHEET}

License Number..1.3-1.1.-20!3 3-02

\section{CONDITIONS (Continued)}

16. All metal containers shall be secured by an intact heavy duty closure device when presented for disposal. Closure devices of open-head drums having 55-gallons or greater capacity shall be secured by bolts having $5 / 8$ inch or larger diameters. DOT $7 A$ Type A containers shall be tested by the generator or shall meet the use restrictions contained in "DOT $7 A$ Type A Certification Document," MLM 3245. Appendix A lists examples of those containers and restrictions.

17. Radioactive waste shall be packaged in such a manner that waste containers received at the facility do not show:
a. Significant deformation,
b. Loss or dispersal of contents,
c. An increase in the external radiation levels as recorded on the manifest, within instrumental tolerances, or
d. Degradation due to rust or other chemical action which results in a loss of container integrity.

18. Void spaces within the radioactive waste and between the waste and its package shall be reduced to the maximum extent practicable. Unless specifically approved by the Division, void spaces in Class A stable, Class B and Class C waste packages shall be less than 15 percent of total volume of the disposal package. This requirement does not apply to high integrity containers approved by the Division for use as disposal packages.

19. Waste shall not contain, or be capable of generating, toxic gases, vapors, or fumes during transportation, handing or disposal.

20. No pyrophoric, hazardous, or chemically explosive material or materials which could react violently with water or moisture or when subject to agitation shall be accepted for disposal. 


$$
\text { Paze.....................Pages }
$$

NEYADA STATE HEALTH DIVISION.

\section{RADIOACTIVE MATERIAL LICENSE SUPPLEMENTARY SHEET}

License Number...13-1.-1.-004. 3-02

\section{CONDITIONS (Continued)}

21. Iiquid wastes that have not been treated by either stabilization, solidification, or sorption cannot be received by the licensee.

22. The licensee shall not accept radioactive waste unless each waste package has been:

a. Classified in accordance with Appendix $B$ of this license and "Low-Level Waste Licensing Branch Technical Position on Radioactive Waste Classification," issued May 1983 by the U.S. Nuclear Regulatory Commission.

b. Marked as either Class A stable, Class A unstable, Class B or Class $C$, as defined in Appendix $B$ of this license and "LowLevel Waste Iicensing Branch Technical Position on Radioactive Waste Classification," issued May, 1983 by the U.S. Nuclear Regulatory Commission; and

c. Stabilized, when required by this license, in accordance with criteria contained in "Technical Position on waste Forms," issued May, 1983 by the U.S. Nuclear Regulatory Commission using only those stabilization media approved by the Division and 1 isted in Appendix $D$ to this license, or Hign Integrity Containers approved by the Division. Stability may also be achieved using engineered barriers in the disposal unit. Specific approval of the Division is required prior to construction of any engineered barrier.

23. The classification marking required by Condition 22 is in addition to any marking or labeling required by U.S. NRC or U.S. DOT and shall consist of lettering $1 / 2$ inch high or greater in a durable contrasting color to the background surrounding the lettering. The classification marking shall be visible on the same side as the radioactive marking or label and in close proximity (within six inches). Waste packages marked "Radioactive", "Limited Quantity" or "Radioactive LSA" need only one classification marking whereas waste packages labeled white I, Yellow II or Yellow III shall have classification markings in close proximity (within six inches) to each label.

Date. 


$$
\text { Page...........ot...23 Pages }
$$

NEVADA STATE HEALTH DIVISION.

\section{RADIOACTIVE MATERIAL LICENSE SUPPLEMENTARY SHEET}

Lieense Number..13-11-0043-02

CONDITIONS (Continued)

\section{SPECIFIC WASTE FORM REQUIREMENTS}

24. Iiquids shall be rendered noncorrosive ( $\leq \leq \mathrm{pH} \leq 11$ ) prior to treatment. Acceptable treatments are stab̄ilizātion, solidification, or sorption, depending on waste class. Wet sludges or slurries, such as evaporator bottoms, shall be noncorrosive and shall be treated by stabilization or solidification. Ion exchange media shall not be treated by sorption.

25. Liquids treated by stabilization shall be processed in accordance with a process control program using an approved stabilization medium (see Appendix D.) The resulting waste form shall be certified by the generator as containing no detectable free-standing liquid and shall meet the stability requirements of condition 22 . No detectable free standing liguid is defined in this condition to be as little free standing and noncorrosive liquid as is reasonably achievable, but in no case shall the liquid exceed one percent of the volume of the waste when the waste is in a disposal container designed to ensure stability, or 0.5 percent of the volume of waste processed to a stable form.

26. Liquids treated by solidification shall be processed in accordance with a process control program using an approved solidification medium (see Appendix C). The resulting waste form shall be certified by the generator as containing no detectable freestanding liquid. No detectable free standing liquid is defined in this condition to be as little liquid as is reasonably achievable but in no case shall it exceed more than 0.5 percent (by volume) of liquid per container.

27. Liquids treated by sorption may be received provided that:

a. A metal outer disposal container is used which meets DOT 7A performance specifications and heavy duty closure devices as required by condition 16.

FOR THE NEVADA STATE HEALTH DIVISION By

Date. 


$$
\text { Page.......................Pages }
$$

NEVADA STATE HEALTH DIVISION.

\section{RADIOACTIVE MATERIAL LICENSE SUPPLEMENTARY SHEET}

License Number...13-11-0043-02

\section{CONDITIONS}

27. (Continued)

b. The metal container is lined with a minimum of 4 mil plastic liner, except as noted in Appendix $\mathbf{E}$.

c. The amount of sorbent used is enough to sorb at least twice the volume of liquid in the container.

d. Only sorbents approved by the Division shall be used (see Appendix El.

e. The resulting waste form shall be certified by the generator as containing no detectable free standing liquid.

f. A quality control program is used which verifies that the above conditions are met.

28. Waste containing biological (excluding animal carcasses) pathogenic, or infectious material, or equipment (e.g. syringes, test tubes, capillary tubes) used to handle such material, shall be treated to reduce, to the maximum extent practicable, the potential hazard from the non-radiologic materials. The inner waste container shall be a metal container meeting either DOT $7 A$ performance specifications (see Condition 16) or manufactured to DOT $17 \mathrm{H}$ specifications and shall be lined with a minimum of $4 \mathrm{mil}$ plastic liner which shall be sealed. The inner waste container shall be placed in an outer metal container meeting DOT 7A performance specifications with a heavy duty closure device (see Condition 16 ) and shall have a capacity at least 40 percent greater than the inner container. The void between inner container and outer container shall be completely filled by approved sorbent material and the outer container must be sealed. Only sorbents approved by the Division shall be allowed. (See appendix E).

FOR THE NEVADA STATE HEALTH DIVISION By

Dase. 


$$
\text { Page...8 . of...2.3....Pazes }
$$

NEVADA STATE HEALTH DIVISION.

\section{RADIOACTIVE MATERIAL LICENSE SUPPLEMENTARY SHEET}

License Number..13-11-0043-02

\section{CONDITIONS (Continued)}

29. Animal carcasses containing, or contained in, radioactive materials shall be packaged with the following requirements: the biological material shall be layered with absorbent and lime placed in a metal container meeting either DOT $7 A$ performance specifications or manufactured to DOT $17 \mathrm{H}$ specifications, having a heavy duty closure device (see condition 16). The inner container shall be sealed and placed in a metal container meeting DOT 7A performance specification with a heavy duty closure device, having a capacity at least 40 percent greater than the inner container. The void between the inner container and the outer container shall be completely filled by approved sorbent material and the outer container must be sealed. Only sorbents approved by the Division shall be used. (See Appendix E).

30. Waste in gaseous form must be packaged at a pressure that does not exceed 1.5 atmospheres at $20^{\circ} \mathrm{C}$. Total activity shall not exceed 100 curies per container. Class $A$ gaseous waste shall be contained within U.S. DOT specification cylinders. Specific approval of the Division is required if the gaseous waste is Class $B$ or $C$.

31. Radium waste must be in the form of sealed sources and packaged in a $2 R$ container, or equivalent. If the $2 R$ container is placed in another container it must be imobilized in the center of the second container with concrete.

32. Radioactive consumer products, the use and disposal of which is exempt from licensing control, may be received without regard to concentration limits of Appendix B provided the entire unit is received and is packaged with sufficient sorbent material so as to preclude breakage and rupture of its contents. This condition allows the disposal of such consumer products as intact household or industrial smoke detector units containing americium-241 foils, or other radioactive materials incorporated into selfluminous devices and electron tubes. Only sorbents approved by the Division shall be used. (See Appendix E). 


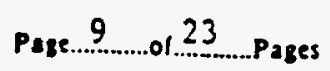

NEVADA STATE HEALTH DIVISION.

\section{RADIOACTIVE MATERIAL LICENSE SUPPLEMENTARY SHEET}

License Number...13-1.1-0.043-02

\section{CONDITIONS (Continued)}

33. Class A incinerator ash shall be solidified, granular or treated in such a manner as to be rendered nondispersible in air, exclusive of packaging.

34. The licensee shall not accept for disposal any neutron source (i.e.. a radionuclide in combination with beryllium or other target) unless the generator has notified the licensee of the intent to ship such source to the licensee's disposal facility. The notification shall consist of telephone notification to the FRC \& So prior to shipment. The notification shall indicate the isotope, activity, form of the source, a description of the packaging utilized and anticipated date of arrival.

35. Waste liquids which have a pre-treatment concentration of oil in excess of ten percent by weight, shall be treated by either solidification or stabilization. Dilution by solidification or stabilization media shall not be allowed in determining waste composition. Oil means an organic liquid which is immiscible in water, the disposal of which is not regulated under RCRA or the state hazardous waste laws.

\section{RECEIPT, ACCEPTANCE AND INSPECTION CONDITIONS}

36. The licensee is exempt from the timely inspection requirements of NAC 459.358 (2) and (4) provided the requirements of the Facility Standards Manual and Conditions 37 and 38 of this license are met.

37. Waste shipments shall not be accepted at the facility unless accompanied by a shipment manifest meeting the requirements of NAC 459.823.

38. a. The licensee shall acknowledge receipt of the waste as soon as practicable, but no later than seven days following its acceptance for disposal by returning a signed copy of the manifest or documentation which refers specificaliy to the manifest by number, to the shipper. The shipper to be notified by the licensee is the one last possessing the waste and transferring it to the licensee.

FOR THE NEVADA STATE HEALTH DIVISION By

Date. 


$$
\text { Page.10.....ot..23....Pages }
$$

NEYADA STATE HEALTH DIVISION.

\section{RADIOACTIVE MATERIAL LICENSE SUPPLEMENTARY SHEET}

License Number..13-11-0.043-02

\section{CONDITIONS}

\section{8. (Continued)}

b. The licensee shall indicate on the returned copy of the shipment manifest, shipping papers, or equivalent documentation any discrepancy between noted waste descriptions listed on the manifest or papers and the waste materials received in the shipment. The licensee shall also notify the Division of any discrepancies within 24 hours after discovery of the discrepancies.

c. The licensee shall notify the shipper and the Division when any shipment or part of a shipment has not arrived 30 days after the separate copy of the shipment manifest was received by the licensee.

d. The licensee shall maintain copies of completed shipment manifests including annotations of discrepancies found in accordance with condition $39 \mathrm{~b}$.

\section{DISPOSAL OPERATING CONDITIONS}

39. Unless specifically authorized by the Division, the licensee is not authorized to open any package containing radioactive material at the facility, except for the following:

a. For purposes of repairing, repackaging or overpackaging leaking containers or containers damaged in transport in the event the material is to be disposed of or returned to the generator, if required for the protection of the health and safety of the employees or the environment; or 
Page...1......of...23.....Pages

NEYADA STATE HEALTH DIVISION.

RADIOACTIVE MATERIAL LICENSE

SUPPLEMENTARY SHEET

License Number ...23-.11--0.043-02

\section{CONDITIONS}

\section{9. (Continued)}

b. Inspection in the presence of or at the request of the

Division for compliance with state regulations, conditions of U.S. Ecology's operating license and the free standing liquid reguirements of License 13-11-0043-02. The package shall be sealed after inspection so that it may be disposed of in the disposal unit. If the package is in noncompliance with any applicable listed requirements, the generator shall be notified and corrective action taken to comply with requirements or to remanifest the package for return to the shipper.

c. For purposes of returning outer shipping containers (i.e. cask shipments).

40. Waste containing chelating agents in excess of one percent by weight must be stabilized. The resultant waste form shall be certified by the generator as containing no detectable free standing liquid. The waste package containing the chelates shall be separated from other waste packages by at least ten feet of dirt, unless the container is a high integrity container approved by the Division. Several packages containing chelates may be buried together and separated from other waste, with specific approval of the Division.

41. All disposal trenches or disposal units shall be in a controlled area surrounded by a chain link fence, eight feet high, and topped with barbed wire.

42. Trenches constructed in the radioactive waste disposal area shall not exceed 50 feet in depth. The licensee shall notify the Division at least 60 days prior to construction of any disposal trench and with that notification supply detailed engineering plans for the trench. Construction of a new trench requires specific approval of the LLW Project Manager.

43. The licensee shall conduct closure and stabilization operations in accordance with the Facility Closure and stabilization Plan dated December 21, 1989 and in accordance with section XVIII of the lease between U.S. Ecology, Inc. and the State of Nevada.

FOR THE NEVADA STATE HEALTH DIVISION

By.

Date. 


$$
\text { Pase......................Pases }
$$

NEYADA STATE HEALTH DIVISION.

\section{RADIOACTIVE MATERIAL LICENSE SUPPLEMENTARY SHEET}

License Number...13-11-0043-02

\section{CONDITIONS (Continued)}

44. After the excavation of each disposal unit has been completed and prior to commencement of actual disposal operations in that trench, the boundaries of the trench shall be located by an engineering survey referenced to benchmarks or other permanent features such that the boundaries can be relocated by future engineering surveys. The trench dimensions shall then be depicted on a scale drawing of the disposal site (plot plan) showing its location with respect to other trenches and other physical features of the site such as buildings, fences, and sampling wells.

45. Starting with Trench 22, upon completion of disposal operations in a disposal unit, the licensee shall backfill the waste completely so that there is a minimum of eight feet of earth between the last layer of waste and present grade.

46. Within six months of completion of disposal operations in a disposal unit, suitable monuments shall be installed on the centerline at one or both ends of the disposal unit. A corrosion and weather resistant plate with the following information clearly engraved or stamped into it shall be permanently affixed to each monument:
a. The number assigned to the dispoal unit.
b. The date of start and completion of disposal operations in the disposal unit.
c. The total activity of radioactive materials in curies, the total amount of source materials in kilograms; and the total amount of special nuclear materials in grams.

FOR THE NEVADA STATE HEALTH DIVISION

By

Date 
NEYADA STATE HEALTH DIVISION.

RADIOACTIVE MATERIAL LICENSE

SUPPLEMENTARY SHEET

License Number...13-11-0043-02

\section{CONDITIONS}

46. (Continued)

d. The total volume in cubic feet of waste disposed of in the disposal unit.

e. The coordinates of the corners of the disposal unit.

The information required by this condition, in addition to being referenced on the permanent monuments, shall be filed by written report to the Division of Health, Capitol Complex, Carson City, Nevada.89710, within thirty days after closure of a disposal unit.

47. Unless placed into storage, all radioactive waste shall be disposed of by the licensee within three working days of receipt. Waste will be considered to be disposed of when it has been placed in its disposal location within the operational trench. Backfill will be placed subsequent to disposal in accordance with site procedure to minimize voids between containers and to achieve acceptable dose rates in the disposal unit and surrounding areas.

Storage shall not exceed sixty days from the date of receipt of radioactive waste by licensee.

\section{ENVIRONMENTAL AND SURVEY CONDITIONS}

48. The licensee shall conduct an environmental monitoring program capable of detecting the potential contribution of radioactive material from the site to the environment. The program shall include collections of samples and analyses at frequencies specified in the facility standards Manual. In addition, the licensee shall report any environmental monitoring results in excess of action levels specified in the facility standards Manual.

FOR THE NEVADA STATE HEALTH DIVISION

By

Date. 


$$
\text { Paze............or..........Pages }
$$

NEVADA STATE HEALTH DIVISION.

\section{RADIOACTIVE MATERIAL LICENSE SUPPLEMENTARY SHEET}

License Number...13-11-0043-02

\section{CONDITIONS (Continued)}

49. The expiration date of this license applies only to the aboveground activities and to the authority to dispose of low-level radioactive wastes at the site specified in condition 10 . The license continues in effect and the responsibility and authority for possession of disposed of low-level radioactive wastes continues until the Division finds that the plan established for preparation of the Beatty Facility for transfer to another person or custodial agency has been satisfactorily implemented in a manner so as to reasonably assure protection of the public health and safety and the environment and the Division takes action to terminate the licensee's responsibility and authority under this license. All reguirements for environmental monitoring, site inspection, maintenance and site security continue whether wastes are being disposed of or not.

50. By September 30, 1990, the license shall supply the Division with the results and analyses of all environmental monitoring conducted by or for the licensee since operations began, including appropriate statistical assessments of possible trends and discussion of any anamalous results and actions taken, if any.

52. By January 1, 1991, the licensee shall supply the Division with a complete waste inventory in the site. The contents of each trench is to be 1 isted by: radionuclide; for byproduct material and naturally occurring radioactive material such as radium, in millicuries of activity; for special nuclear material, in grams; for source material, in kilograms. Upon completion of the inventory, the licensee shall use the inventory in calculation of a source term for the site and as a new basis for performing a pathway of migration analyses. These two calculations shall be provided to the Division on or before June $30,1991$. 
Page.1.5......ol..23.....Pages

NEYADA STATE HEALTH DIVISION.

RADIOACTIVE MATERIAL LICENSE

SUPPLEMENTARY SHEET

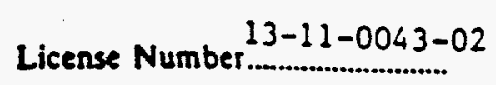

CONDITIONS (Continued)

52. Notwithstanding other requirements of this license or the lease, one year prior to the anticipated transfer of the I icensee's facility and buried radioactive waste to another person (including an agency of the state or federal government), the licensee shall submit a final version of the facility closure plan. including a schedule for implementation of all remaining plan elements prior to transfer, and a description of the mechanics of orderly transfer in coordination with the transferee.

53. Except as specifically provided by this license, the licensee shall possess and use radioactive material described in Items 6 , 7 and 8 of this 1 icense in accordance with statements, representations, and procedures contained in the documents listed below. Chapter 459 of NAC shall govern the licensee's statements in applications or letters, unless the statements are more restrictive than the regulations. Any changes to the documents listed below shall require Division approval in the form of an amendment to this license.

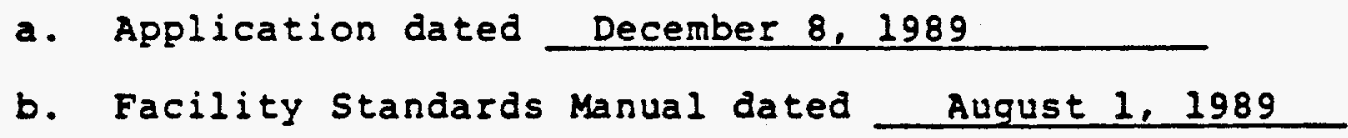

Date..........nber 29, 1989

GEORGE E. RENWLDS, Y.D. ACTING STATE HEALTH OFFICER

FOR THE NEVADA STATE HEALTH DIVISION

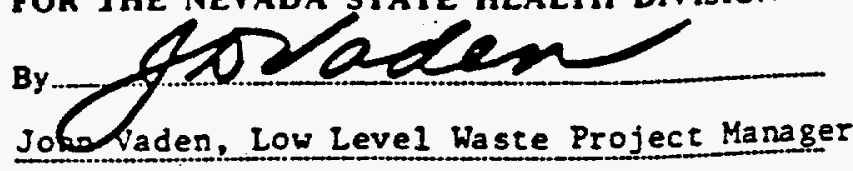




$$
\text { Paze...16..................Pazes }
$$

NEVADA STATE HEALTH DIVISION.

RADIOACTIVE MATERIAL LICENSE

SUPPLEMENTARY SHEET

\section{APPENDIX A}

License Number............................

\section{EXAMPLES OF CONTAINERS MEETING 7A PERFORMANCE SPECIFICATION AND HAVING A HEAVY DUTY CLOSURE DEVICE}

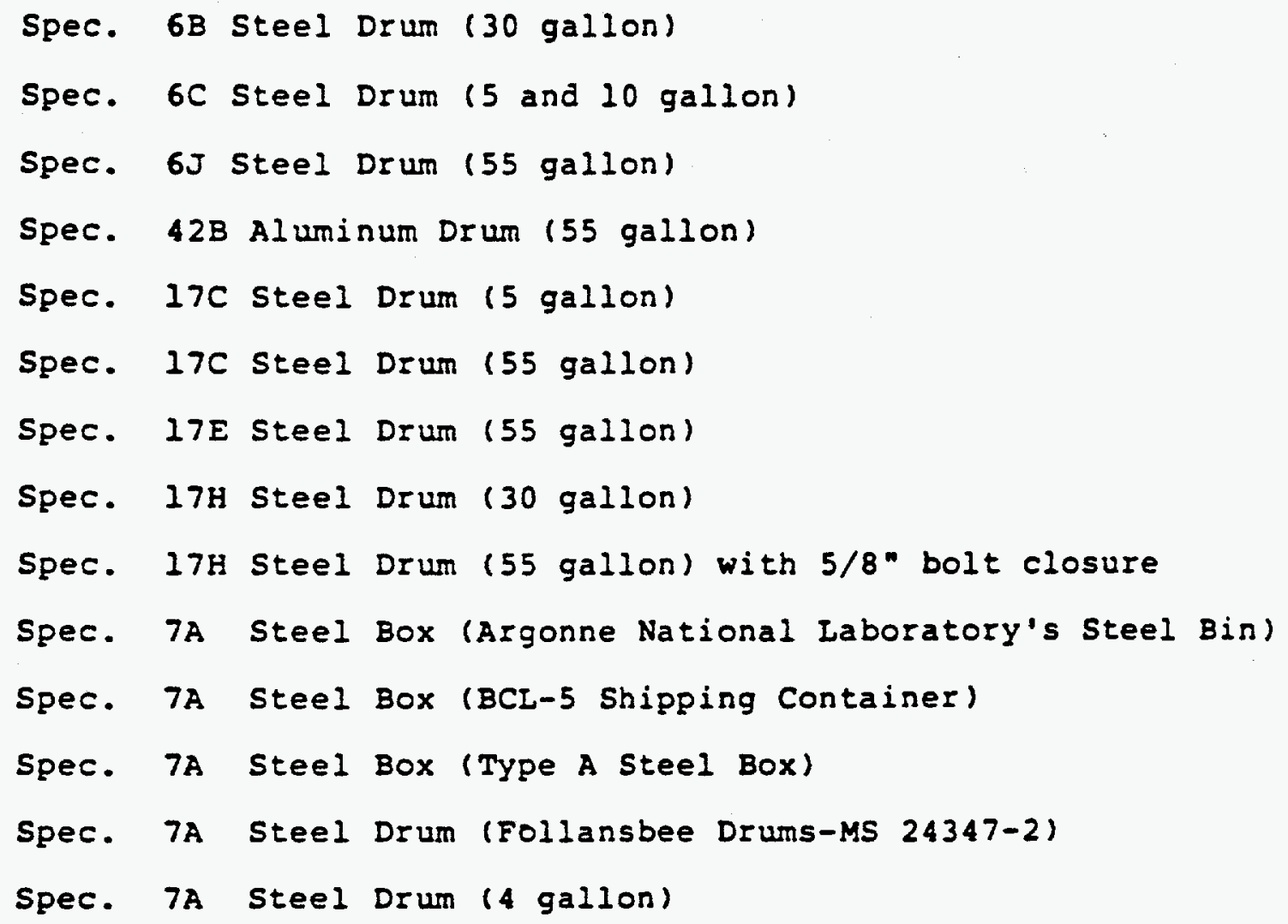

FOR THE NEYADA STATE HEALTH DIVISION

By

Date. 


$$
\text { Page..........ol } 23 \text {....Pazes }
$$

NEVADA STATE HEALTH DIVISION.

RADIOACTIVE MATERIAL LICENSE SUPPLEMENTARY SHEET

License Number $13-11-0043-02$

APPENDIX B

WASTE CLASSIFICATION TABLE

RADIONUCLIDES

Table 1 (Long-Lived)

C-14

C-14 in activated metal

Ni-59 in activated metal

No-94 in activated metal

Tc-99

I-129

Alpha-emitting Transuranics with half-life greater than 5 years

Pu-241

Cm-242

Table 2 (Short Lived)

Total of all radionuclides with half-life less than

5 years

H-3

Co- 60

$\mathrm{Ni}-63$

$\mathrm{N} i-63$ in activated metal

S5 -90

Cs -137
Class A

Class $B$

Class C

CONCENTRATION LIMITS IN CURIES/CUBIC METER
0.8
8
22
0.02
0.3
0.008

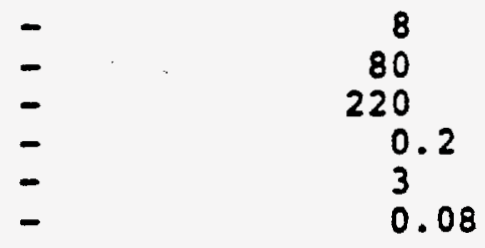

CONCENTRATION LIMITS IN NANOCURIES/GRAM

10

100

350

2000

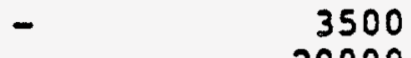

- 20000

CONCENTRATION LIMITS IN CURIES/CUBIC METER

700

40

700

3.5

35

0.04

70

700

700

7000

150

7000

$104 \quad 4600$

NOTE: Wastes with concentrations exceeding Class $C$ are not acceptable for burial.

FOR THE NEVADA STATE HEALTH DIVISION

By

Date. 


$$
\text { Paze...18.....of...23...Pages }
$$

NEYADA STATE HEALTH DIVISION.

\section{RADIOACTIVE MATERIAL LICENSE SUPPLEMENTARY SHEET}

APPENDIX B (cont)

License Number...13-11-......................

1. Unless specifically restricted elsewhere in the license, the concentration of a radionuclide or radionuclide mixture may be averaged over the volume (or mass) of the waste and, if used, the solidification agent or matrix. The concentration of radionuclides in filters encapsulated with a solidification agent or matrix can be averaged over the volume of the solidified mass. Further guidance is provided in "Low Level waste Licensing Branch Technical Position on Radioactive Waste Classification," May 1983. or successor documents issued by the U.S. Nuclear Regulatory Commission.

2. The waste is Class $A$ if none of the listed radionuclides is present. Waste packaged in accordance with condition 32 of this license shall be class $\mathrm{A}$ unstable.

3. There are no upper limits in class $B$ for the first three nuclides listed in Table 2, as transportation and safety requirements involving radiation levels and internal heat generation will effectively limit the concentrations.

4. There are no Class $B$ values for radionuclides listed in Table 1; their presence classifies the waste as either Class A or Class C according to their concentrations.

5. The waste class for mixtures of the listed radionuclides is determined by deriving for each radionuclide the ratio between its concentration in the mixture and its concentration limit in the table of this license adding the resulting ratio values for each radionuclide group. All limits used in the concentrations must be for the same waste class. The sum of the ratios for radionuclides in each table must be equal to, or less than, 1.0 or the waste is the next higher classification than that used for the calculation.

If Class C limits are used in the calculation and the sum of ratios for either table exceeds 1.0 , the waste is not acceptable for near-surface disposal.

6. If radioactive waste contains a mixture of radionuclides, some of which are listed on Table 1 and some of which are listed on Table 2 , classification shall be determined as follows:

FOR THE NEVADA STATE HEALTH DIVISION

By

Date. 


$$
\text { Paze.............ol..........Pazes }
$$

NEYADA STATE HEALTH DIVISION.

\section{RADIOACTIVE MATERIAL LICENSE SUPPLEMENTARY SHEET}

APPENDIX B (cont)

License Number $13-11-0043-02$

(i) If the concentrations of a nuclide listed in Table 1 does not exceed the Class A limit listed in Table 1, the class shall be that determined by the concentration of nuclides listed in Table 2 .

(ii) If the concentration of a nuclide listed in Table 1 exceeds the Class A limit listed in Table 1 , but does not exceed the Class $C$ limit, the waste shall be Class $C$, provided the concentration of nuclides listed in Table 2 does not exceed the Class $C$ value.

FOR THE NEVADA STATE HEALTH DIVISION

By

Date. 
NEVADA STATE HEALTH DIVISION.

\section{RADIOACTIVE MATERIAL LICENSE SUPPLEMENTARY SHEET}

\section{APPENDIX C \\ SOLIDIFICATION MEDIA}

License Number...13-1.1-0.0.4.3-02

Only approved solidification media can be used. Approved solidification media are:

1) Aztech (General Electric)

2) Aquaset I and II

3) Bitumen* (Waste Chem and ATI)

4) Chem-Nuclear Cement

5) Concrete (Structural)

6) Delaware Custom Media

7) Dow Media

8) Envirostone

9) Hittman Grout

10) Petroset I and II

11) Safe T Set

12) Other solidification media and processes which have been approved by USNRC or the Division.

- Note: For waste types that require solidification, both oxidized bitumen and straight distilled are acceptable.

Solidification means a resultant waste form which is a free standing solid and primarily relies upon a chemical reaction or encapsulation to contain the liquid. Approved stabilization media may also be used as solidification agents without conducting tests necessary to verfiy stability provided the resulting waste form is a free standing solid.

It is the responsibility of the person processing the waste into a solid form to adhere to a quality control program to verify the waste form is appropriate. If a material can also be used as a sorbent, the restrictions noted for its use in Appendix $E$ shall apply to its use as a solidification agent.

FOR THE NEVADA STATE HEALTH DIVISION By

Date. 
NEVADA STATE HEALTH DIYISION.

\title{
RADIOACTIVE MATERIAL LICENSE SUPPLEMENTARY SHEET
}

\author{
APPENDIX D

\section{APPROVED STABILIZATION MEDIA}

License Number.

Only those stabilization media which have been evaluated and are used with the stability guidance requirements of the U.S. Nuclear Regulatory Commission's Low-Level Licensing Branch, Technical Position on Waste Form or are specifically approved by the Division are considered acceptable stabilization media. Approved stabilization media are:

1) Aztech (General Electric)

2) Bitumen* (ATI and Waste Chem)

3) Chem-Nuclear Cement

4) Concrete*

5) Dow Media (Vinyl Ester Styrene)

6) IN Technologies Cement

7) Stock Equipment Cement

B) Westinghouse - Bittman Cement

9) Other stabilization media and processes which have been reviewed and approved by the U.S. NRC or the Division as meeting waste form stability criteria.

* Note: Oxidized Bitumen only.

* Concrete, when used as an encapsulation medium around a small volume of radioactive material, e.g., a sealed source centered in a fiftyfive gallon drum containing concrete, shall have a formulated compressive strength greater than or equal to $2,500 \mathrm{psi}$.

FOR THE NEVADA STATE HEALTH DIVISION

By.

Date. 


$$
\text { Page....................Pages }
$$

NEVADA STATE HEALTH DIVISION.

\section{RADIOACTIVE MATERIAL LICENSE SUPPLEMENTARY SHEET}

APPENDIX E

License Numbes...13-11-1-0043-02

\section{Approved Sorbents}

Only those absorbents 1 isted below have been approved by the Division for general use in processing radioactive liquids or with materials that may contain a quantity of liquid that requires absorbing.

Absorbency efficiencies and quantity of absorbent required vary. In all cases, it is the responsibility of the waste generator or packager to determine the efficiency and proper proportions of absorbent for liquids being absorbed. Note: Enough absorbent materials must be provided to absorb at least twice the volume of liquid in the waste.

\section{Media}

이

Water

A. Clay Materials

1. Speedi Dri

2. Hi Dri

3. Florco

4. Florco $X$

5. Instant Dri

6. Safe T Sorb

7. Opalex

B. Diatomaceos Earths

1. Superfine

2. Floor Dry

3. Celetom

4. Safe N Dri

5. Solid-A-Sorb

c. Perlite

1. Chemsil 30

2. Chemsil 50

3. Chemsil 3030

4. Dicaperl HP200

5. Dicaperl HP500
Approved

Not Approved

Approved

Not Approved

Not Approved

Not Approved

Approved

Approved

Approved

Approved

Approved

Approved

Not Approved

Approved

Approved

Approved

Approved
Approved Approved Approved Approved Approved Approved Approved

Approved Approved Approved Approved Approved

Approved Approved Approved Approved Not Approved

FOR THE NEVADA STATE HEALTH DIVISION

By

Date. 


$$
\text { Page..........or..........Pages }
$$

NEVADA STATE HEALTH DIVISION.

\section{RADIOACTIVE MATERIAL LICENSE SUPPLEMENTARY SHEET}

$$
\text { APPENDIX E (Cont.) }
$$

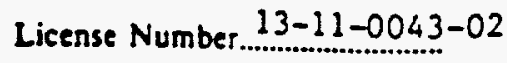

Approved Sorbents

\section{Media}

\section{A. Others}

1. Dicalite Dicasorb
2. Petroset**
3. Petroset II**
4. Aquaset*
5. AquasetII**
6. Safe T Set

Oil

Approved Approved * * Approved Not Approved Not Approved Not Approved
Water

Not Approved Approved* * Not Approved Approved Approved Approved

* Not for use with pure water

* Note: The products Aquaset, Aquaset II, Petroset, and Petroset II are exempt from Condition 27. These products only shall be used without an inner 4 mil plastic liner. Additionally, these products when used in accordance with the manufacturer's procedures incorporate the reguirement of enough absorbent material to absorb at least twice the volume of radioactive liquid content.

***Note: The product Petroset is primarily used in conjunction with Petroset II or Aquaset II when a mixture of water and oils are present and the oils are in excess of five percent of the waste volume. Use of Petroset requires power mixing equipment.

FOR THE NEVADA STATE HEALTH DIVISION

By

Date. 


\section{RADIOACTIVE MATERLAL LICENSE SUPPLEMENTARY SHEET}

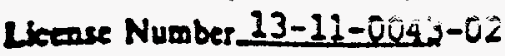
Amerdment No. 24

U. 5. Ecology, Inc.

P. O. Bax 7246

Louisville, KY 40207

Nevada Radiaactive Material License No. 13-11-0043-02 is anended as follows:

TO CHANGE:

Condition 52 located on Page 14 of the iicense to read:

51. By June 30, 1991, the licensee shall omply the Division with a complete waste inventory in the site. The contents of each trench is to be listed by: radionuclide; for byproduct materiel and naturally occurring radioactive material such as radium, in millicuries of activity; for opecial nuclear material, in grans: for source material, in kilograns. Upon campletion of the inventory, the licensee shall use the irventory in calallation of a source term for the site and as a new basis for performing a patiway of migration analyses. These two calculations shall be provided to the Division on or before December 31. 1991.

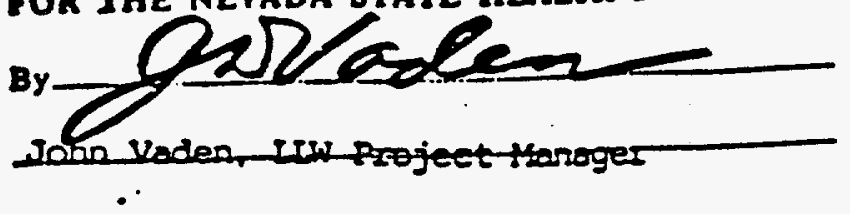




\section{Radioactive Materials License}

$$
\text { Page } 1 \text { of } 36 \text { Pages }
$$

Pursuant to the Nuclear Energy and Radiation Control Act, RCW 70.98, and the Radiation Control Regulations, Chapters 246-220 through 246-5j WAC. and in reliance on stements and representations heretofore made by the licensee designated bejow, a license is hereby issued authonzing such licensee to transfer, receive, possess and use the radioactive material(s) desigrated below; and to use suca radianctive matenals for the purpose(s) and at the place(s) designated below. This license is sabject to all applicable rules and regulations promulgated by the Sate of Washington Department of Health

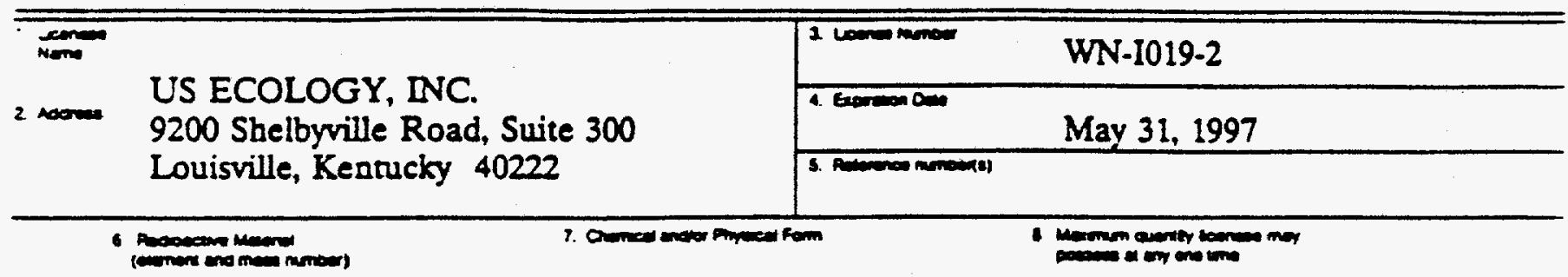
A. Any radioactive material
A. Dry packaged radioactive excluding source material and special nuclear waste except as authorized by this license.
A. 60,000 curies (2.22 $\times 10^{\text {ts }}$ Bequerels). material.

B. Source material.

C. Any radioactive material, excluding special nuclear material.
B. Dry packaged radioactive waste except as authorized by this license.

C. Check and calibration sources in any form.
B. 36,000 kilograms.

C. 0.1 Curie (3.7 $x 10^{\circ}$ Bequerels).

$$
\langle\langle\cdot\rangle\rangle+\langle\langle\cdot\rangle\rangle+\langle\langle\cdot\rangle\rangle+\langle\langle\cdot\rangle\rangle+\langle\langle\cdot\rangle\rangle+\langle\langle\cdot\rangle\rangle+\langle<\cdot\rangle
$$

\section{CONDIIIONS}

9. Authorized use.

A\&B Radioactive waste may be received, transferred, stored, repackaged, and disposed at a low-level radioactive waste disposal facility. The maximum radioactivity and/or quantity of radioactive material indicated in items 8.A and 8.B applies only to above-ground activity. 
State of Washington

\section{Radioactive Materials License}

Page 2 of 36 Page

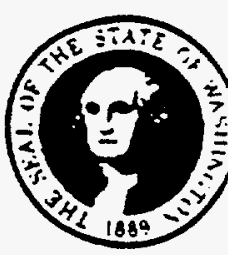

WN-1019-2

Liane Number

Amendment No. 18

10. The authorized place of use is a low-level waste burial facility located in the southeast corner of Section 9, Township 12 North, Range 26E W.M., Benton County, Washington, Route 4 - U.S. DOE Hanford Reservation, Richland, Washington 99352, within the boundary of the land area described in Sublease Agreement with the state of Washington, dated July 29, 1965, as amended. For the purposes of this license, the authorized place of use shall be referred to as the "facility".

11. Reference to the "deparment" in this license shall mean the Deparment of Health or successor agency.

12. The licensee shall notify the department in writing within $\mathbf{3 0}$ days of the appointment of a new Facility Manager, Facility Assistant Manager, and Corporate or Facility Radiological Control and Safety Officer, describing how the appointee meets or exceeds the minimum qualifications specified in the Facility Standards Manual.

13. By October 30, 1992, the licensee shall submit to the department for approval a complete copy and description of all revisions to Richland Facility Operations Procedures which are necessary to comply with the provisions of this license.

14. Upon receipt of a shipment, the licensee shall fumish to the department copies of all shipment manifests received. The licensee shall furnish to the department, within 30 days of a specific written request, special reports consisting of selected information contained on shipment manifests. By the loth of each month, the licensee shall submit a report totaling the volume and activity of the waste received during the previous month. In addition, a monthly facility receipt and burial activities report shall be submitted by the licensee, no later than the 15th day of the following month to the Department of Health, Head, Waste Management Section. The report shall include the following information for each shipment:

A. Name and address of the generator(s), broker (if any), and shipper.

B. Radionuclides and activity of each radionuclide in millicuries (total and by generator).

C Grams of special nuclear material as received under NRC License No. 16-19204-01 (total and by generator).

D. Mass (in kilograms) of source material received (total and by generator).

E. Class totals of volume and activity of Class $A, B$, and $C$ waste entrenched (total and by generator). 


\section{State of Washington \\ Radioactive Materials License \\ Page 3 of 36 Pagu

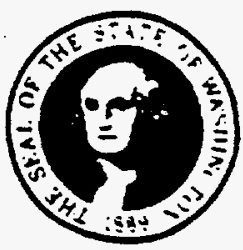 \\ Lomen Number WN-1019-2 \\ Amendment No. 18}

F. Volume of packages disposed with radiation readings at the surface of the disposal container of:

$$
\begin{aligned}
& \leq 50 \mathrm{mr} / \mathrm{hr} \\
& >50 \mathrm{mR} / \mathrm{hr} \leq 200 \mathrm{mR} / \mathrm{hr} \\
& >200 \mathrm{mR} / \mathrm{hr} \leq 1 \mathrm{R} / \mathrm{hr} \\
& >1 \mathrm{R} / \mathrm{hr} \leq 10 \mathrm{R} / \mathrm{hr} \\
& >10 \mathrm{R} / \mathrm{hr} \leq 100 \mathrm{R} / \mathrm{hr} \\
& >100 \mathrm{R} / \mathrm{hr}
\end{aligned}
$$

and to the extent practicable:

G. Type and physical form of the waste.

H. Chemical form of the waste and solidification/stabilization/sorption agent used.

I. If an Engineered Barrier with a High Integrity Container (HIC), or High Integrity Container (HIC) was used (total and by generator).

J. Quantity and type of chelates in concentrations greater than 0.1 percent by weight (total and by gene.ator).

15. The licensee shall maintain a record for each shipment of waste disposed at the facility. As a minimum, the record shall include:

A. The date of disposal of the waste.

B. The location of the waste in the disposal site.

C. The condition of the waste packages as received.

D. Any discrepancies between materials listed on the manifest and those received.

E. Any evidence of leaking or damaged packages or damaged packages or radiation or contamination levels in excess of limits specified in United States Department of Transportation and state of Washington regulations. 


\title{
State of Washington \\ Radioactive Materials License \\ Page 4 क 36 Pagm

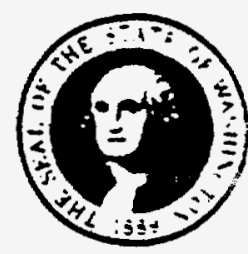

Uane Number

WN.1019-2

Amendment No. 18

\begin{abstract}
F. A description of any repackaging operations of any of the waste packages in the stipment.
\end{abstract}

\section{GENERAL PACKAGING CONDITIONS}

16. All radioactive waste shall be packaged, loaded, received, and transpored in accordance with all applicable U.S. Deparment of Transportation regulations, U.S. Nuclear Regulatory Commission regulations, state regulations, and the requirements of this license. Nothing in this license shall in any way relieve the licensee from full compliance with all applicable state and federal laws and regulations, including but not limited to the Resource Conservation and Recovery Act of 1976, as amended, and the State Hazardous Waste Management Statutes of 1976, as amended, and subsequently enacted regulations.

17. Unless otherwise authorized, the licensee shall not receive for disposal any mixed low-level radioactive waste. Mixed waste is defined as any radioactive material which is no longer of use or value, and contains waste that either 1 ) is listed as dangerous waste in the state's Dangerous Waste Regulations, 2) causes the waste to exhibit any of the dangerous waste characteristics identified in the state's Dangerous Waste Regulations, 3) fulfills any of the 'dangerous waste criteria' identified in the state's Dangerous Waste Regulations, 4) listed as hazardous waste in Subpart D, 40 CFR Parr 261, or 5) causes the waste to exhibit any of the hazardous waste characteristics identified in Subpart C, 40 CFR Part 261.

18. Unless specifically authorized by the department, all radioactive waste shall be received and buried in closed containers. Cardboard, corrugated paper, wood and fiberboard are prohibited burial containers.

19. All metal containers shall be secured by an intact heavy duty closure device when presented for disposal. Closure devices of open-head metal drums having 55-gallons or greater capacity shall be secured by bolts having $5 / 8$ inch or larger diameters. The shipper of any DOT 7A Type A container must maintain on file, a complete documentation of tests and an engineering evaluation or comparative data showing that the construction methods, packaging design, and materials of construction comply with that specification, or shall meet the use restrictions contained in "DOT 7A Type A Certification Document, MLM 3245. Appendix A lists examples of those containers and restricrions. 
State of Washington

\section{Radioactive Materials License}

$$
\text { Page } 5 \text { of } 36 \text { Page }
$$

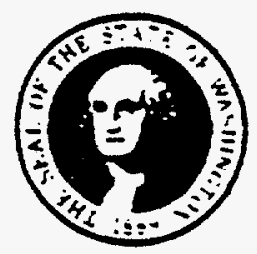

Lane Number WN.I019.?

Amendment No. 18

20. Radioactive waste shall be packaged in such a manner that waste containers received at the facility do not show:
A. Significant deformation.
B. Loss or dispersal of contents.
C. An increase in the external radiation levels as recorded on the manifest, within instrument tolerances.
D. Degradation due to rust or other chemical action which results in a loss of container integrity.

21. Void spaces within the radioactive waste and between the waste and its package shall be reduced to the maximum extent practicable. Unless specifically approved by the department, void spaces in Class A stable, Class B and Class C waste packages shall be less than 15 percent of the total volume of the disposal package, provided the disposal package is not a high integrity container nor contains activated metals that are too large to put into high integrity containers. For Class B and Class $C$ waste packages containing activated metals, voids shall be reduced to the extent practicable and shall be demonstrated to be structurally stable by any of the methods discussed in WAC 246-249-050(2)(a). This documentation shall be submitted to the deparment prior to disposal, and shall be kept on file oy the licensee.

22. Waste shall not contain. or be capable of generating, toxic gases, vapors. or fumes during transportation, handling, or disposal.

23. No pyrophoric, bazardous, dangerous, or chemically explosive materials or materials which could react violently with water or moisnre or when subject to agitation shall be accepted for disposal.

24. Waste or packaging shall not contain any liquid except as authorized by this license.

25. The licensee shall not receive shipments of radioactive material unless appropriate lifting devices of sufficient length bave been provided and securely attached to containers and palletized shipments within a cask. 
State of Washington

\section{Radioactive Materials License}

$$
\text { Page } 6 \text { of } 36 \text { Pagew }
$$

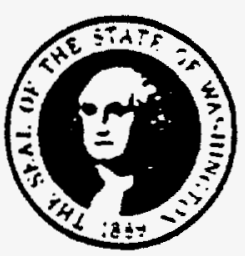

Lare Number

WN-1019-2

Amendment No. 18

26. The licensee shall not accept radioactive waste unless each waste package has been:

A. Classified in accordance with Appendix B of this license and the most recent version of the "Low-Level Waste Licensing Branch Technical Position on Radioactive Waste Classification, issued May 1983 by the U.S. Nuclear Regulatory Commission.

B. Marked as either Class A stable, Class A unstable, Class B or Class C, as defined in Appendix $B$ of this license and the most recent version of the "Low-Level Waste Licensing Branch Technical Position on Radioactive Waste Classification," issued May 1983 by the U.S. Nuclear Regulatory Commission.

C. Marked with a unique package identification number, clearly visible on the package, and can be correlated with the manifest for that particular shipment.

D. Stabilized, when required by this license, in accordance with criteria contained in the most recent version of the "Technical Position on Waste Forms," issued May 1983 by the U.S. Nuclear Regulatory Commission, and procedures that are described in approved vendor topical reports. Only those stabilization media approved by the department and listed in Appendix D to this license, or High Integrity Containers approved by the department and listed in Appendix $\mathrm{E}$ to this license may be used. Stability may also be actieved using engineered barriers in the disposal unit. Specific approval of the department is required prior to construction of any newly designed or redesigned engineered barrier. Only those engineered barriers listed in Appendix F of this license are approved for use at the facility.

27. The classification and package identification marking required by Condition 26 is in addition to any marking or labeling required by U.S. NRC or U.S. DOT and shall consist of lettering $1 / 2$ inch high or greater in a durable contrasting color to the background surrounding the lettering. The classification marking shall be visible on the same side as the radioactive marking or label and in close proximity (within six inches). Waste packages marked "Radioactive", "Limited Quantity," or "Radioactive LSA" need only one classification marking, whereas waste packages labeled White I, Yellow II or Yellow III shall have classification markings in close proximity (within six inches) to each label. Waste materials shipped in casks shall have the classification markings visible on the outside of the cask. 


\section{State of Washington \\ Radioactive Materials License \\ Page 7 of 36 Peger

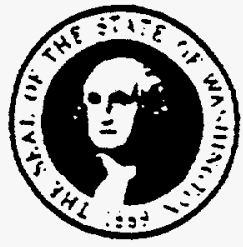 \\ Leene Number WN-1019-? \\ Amendment Nio. 18}

\section{SPECIFIC WASTE FORM REOUIREMENTS}

28. Except as allowed under this license, untreated liquids and wet sludges are not allowed for disposal. Liquids shall be rendered non-corrosive $(4 \leq \mathrm{pH} \leq 11)$ prior to treatment. Acceptable treatments are stabilization, solidification or sorption, depending on waste class. Wet sludges and slurries, such as evaporator bottoms, shall be noncorrosive and shall be treated by stabilization or solidification. Ion exchange media shall not be treated by sorption.

29. Liquids, ion exchange resins, or filter media treated by stabilization shall be processed in accordance with a process control program using an approved stabilization medium (see Appendix D). The resulting waste form shall contain no detectable free-standing liquid and shall meet the stability requirements of Condition 26. "No detectable free-standing liquid" is defined to be as little free standing and noncorrosive liquid as is reasonably achievable, but in no case shall the liquid exceed $1.0 \%$ of the volume of the waste when the waste is in a disposal container designed to ensure stability, or $0.5 \%$ of the volume of waste processed to a stable form.

30. Liquids treated by solidification shall be processed in accordance with a process control program using an approved solidification medium (see Appendix C). The resulting waste form shall contain no detectable free-standing liquid. "No detectable free-standing liquid" is defined to be as little liquid as is reasonably achievable, but in no case shall it exceed more than 0.5 percent (by volume) of liquid per container.

31. Liquids treated by sorption may be received, provided that:

A. A metal outer disposal container is used which meets DOT 7A performance specifications and heavy-duty closure devices as required by Condition 19.

B. The metal container is lined with a minimum of a 4 mil plastic liner, except as noted in Appendix G.

C. The liquid is contained in enough sorbent material to sorb at least twice the volume of the liquid contents. 


\section{State of Washington \\ Radioactive Materials License \\ Page $8 \propto 36 \quad$ Pagu \\ Uaenen Number

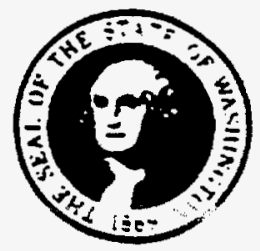 \\ W.1012.?}

Amendment No. 18

D. Only sorbents approved by the department shall be used (see Appendix G).

E. A quality control program is used which verifies that the above conditions are met.

32. Class A radioactive liquids in individual units or vials, not to exceed 50 milliliters per vial and used for clinical or laboratory testing, may be received, provided that:

A A metal outer disposal container is used which meets DOT 7A performance specification (see Condition 19).

B. The metal disposal container is lined with a minimum of a 4 mil plastic liner, except as noted in Appendix G.

C. The individual units are layered in sufficient sorbent material to sorb at least twice the total volume of the liquid contents.

D. Only sorbents approved by the department (see Appeadix $G$ ) shall be used.

33. Waste containing biological (excluding animal carcasses, which are considered in Condition 34), pathogenic, or infectious material or equipment (e.g., syringes, test tubes, capillary tubes) used to handle such material, shall be treated to reduce, to the maximum extent practicable, the potential hazard from the non-radiological materials. The inner waste container shall be a metal container meeting either DOT 7A performance specifications (see Condition 19) or manufactured to DOT 17H specifications and shall be lined with a minimum 4 mil plastic liner which shall be sealed. The inner waste container shall be placed in an outer metal container meeting DOT 7A performance specifications with a heavy duty closure device (see Condition 19) and shall have a capacity at least 40 percent greater than the inner container. The void between inner container and outer container shall be completely filled by approved sorbent material and the outer container must be sealed. Only sorbents approved by the department shall be allowed (see Appendix $G$ ). 


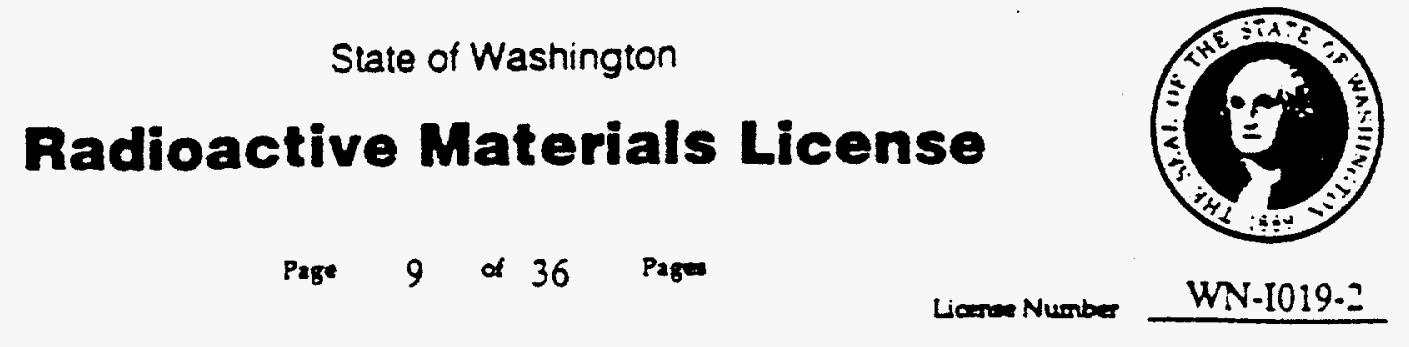

Anendment No. 18

34. Arimal carcasses containing, or contained in, radioactive materials sball be packaged in accordance with the following requirements: the biological material shall be layered with absorbent and lime and placed in a metal container meeting either DOT $7 \dot{A}$ performance specification or manufactured to DOT $17 \mathrm{H}$ specifications, having a beavy duty closure device (see Condition 19). The inner container shall be closed and placed in a metal container meeting DOT 7A performance specification with a heavy duty closure device, having a capacity at least 40 percent greater than the inner container. The void between the inner container and the outer container shall be completely filled by approved sorbent material and the outer container must be sealed. Only sorbents approved by the department (except Perlites) shall be used (see Appendix G).

35. Waste in gaseous form must be packaged at a pressure that does not exceed 1.5 atmospheres at $20^{\circ} \mathrm{C}$. Total activity shall not exceed 100 curies $\left(3.7 \times 10^{12} \mathrm{Bqs}\right)$ per container. Class A gaseous waste shall be contained within U.S. DOT specification cylinders. Class A gaseous waste contained in hermetically sealed glass ampules, tubes, or sealed sources are exempt from the requirement for the specification cylinder provided that they are packaged in containers meeting DOT 7A specifications, having a heavy duty closure device (see Condition 19) and with sufficient sorbent material to prevent breakage and nuprure of its contents. Specific approval of the department is required if the gaseous waste is Class B or C. Oniy sorbents approved by the department shall be used (see Appendix $C$ ).

j6. Class $A$ ion exchange and filter media containing radionuclides with half-lives greater than five years, the total concentration of which is one microcurie $\left(3.7 \times 10^{+} \mathrm{Bqs}\right)$ per cuidic centimeter or greater, except Cobalt 60 naving a concentration of 50 microcuries per cubic centimeter or greater, shall:

A Meet the stability requirements of Condition 26 and shall contain no detectable free-standing liquid. "No detectable free-standing liquid" is defined to mean as little liquid as reasonably achievable. but in no case shall the liquid exceed $1.0 \%$ of the volume of the waste when the waste is in a disposal container designed to ensure stability, or $0.5 \%$ of the volume of waste processed to a stable form. Other Class $A$ ion exchange and filter media which are classified as unstable shall contain no more liquid than $0.5 \%$ by volume of the waste. 


\section{State of Washington \\ Radioactive Materials License \\ Pag* 10 \& 36 Page

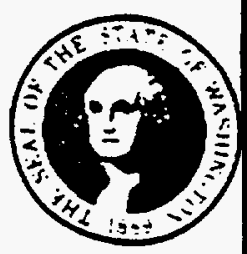 \\ Liarene Number \\ WN.1019-2 \\ Amendment No. 18}

B. The calculations of concentrations of isotope activity will adhere to the "sum of fractions being equal to or less than unity rule" for ion exchange resins and filter media containing isotopes with half-lives greater than five years, with the exception of Cobalt 60.

37. Radioactive waste containing radium and/or transuranic radionuclides, as described in Appendix B, is acceptable, provided that the radium and transuranic radionuclides are essentially evenly distributed within an homogenous waste form. The receipt and disposal of waste in which the radium or transuranic radionuclides are not evenly distributed (components, or equipment primarily contaminated with radium or transuranic radionuclides), or radium or transuranic radionuclides in excess of Class A limits, requires the specific approval of the department. Radioactive waste packaged in accordance with license condition 38 is exempt from this condition.

38. Radioactive consumer products, the use and disposal of which is exempt from licensing control (see WAC 246-232), may be received without regard to concentration limits of Appendix B, provided the entire unit is received and is packaged with sufficient sorbent material so as to preclude breakage and rupture of its contents. Only sorbents approved by the department shall be used (see Appendix G).

This condition allows the disposal of such consumer products as intact household or industrial smoke detector units containing Americium-241 foils, and radium or other radioactive materials incorporated into self-luminous devices and electron tubes. Documentation that the consumer product was manufactured under a U.S. Nuclear Regulatory Commission exempt license shall accompany each shipment made under this condition.

39. Incinerator ash which is classified as Class A waste according to Condition 26 shall be solidified, granular or treated in such a manner as to be rendered nondispersible in air, exclusive of packaging.

40. Until altemative waste management techniques such as incineration or recycling become generally available, waste liquids which have a pretreatment concentration of oil in excess of 10 percent by weight, shall be treated by either solidification or stabilization. Dilution by solidification or stabilization media shall not be allowed in determining waste composition. "Oil" means an organic liquid which is immiscible in water, the disposal of which is not regulated under RCRA or the state hazardous waste laws. 


\section{State of Washington \\ Radioactive Materials License \\ Page $\quad 11 \propto 2 \quad 36 \quad$ Pagu

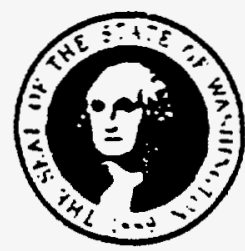 \\ Licene Number W.IO19.?}

Amendment No. 18

41. Until altemative waste management techniques such as incineration or recycling become generally available, waste liquids which have a pretreatment concentration of chelating agents in excess of 1.0 percent by weight, shall be ireated by either solidification or stabilization. Dilution by solidification or stabilization media shall not be allowed in determining waste composition. "Chelating agent" means amine polycarboxylic acids (e.8., EDTA, DTPA), hydroxy-carboxylic acids and polycarboxylic acids (e.g., citric acid, carbolic acid, and glucinic acid), the disposal of which is not regulated under RCRA or the state hazardous waste laws.

42. The licensee shall not accept for disposal any neutron source (e.g., polonium 210, americium 241, radium 226 in combination with beryllium or other target) unless the generator has notified the licensee of the intent to ship such source to the licensees disposal facility. The notification shall consist of telephone and written notification to the Facility Manager prior to shipment. The notisication shall indicate the isotope, activity, form of the source, a description of the packaging utilized, radiological data, and anticipated date of arrival. Additionally, a copy of the written notification must accompany the shipment made under this license condition.

\section{RECEIPT. ACCEPTANCE AND INSPECTION CONDITIONS}

43. The licensee is exempt from the timely inspection requirements of WAC 246-221-160(2)(a) and (3)(a), provided the requirements of the Facility Standards Manual and Conditions 44 through 46 of this license are met.

44. Waste shipments shall not be accepted at the facility uniess accompanied by the jollowing (a single shipment shall consist of not more than one vehicle or one tractor with legal trailer(s) attached):

A Shipment manifest approved by the department.

B. Washington State Patrol or Washington State Utilities and Transportation Commission vehicle inspection certificate, or a current visible Washington State 90-day vehicle inspection seal.

C. Current certification Form RHF-31, properly executed by a representative of the shipper/generator of the waste, in accordance with requirements of Washington State Rules and Regulations For Radiation Protection, WAC 246. 249-030. 


\title{
Radioactive Materials License
}

\author{
Page $12 \propto 36 \quad$ Pagu
}

Licanes Number

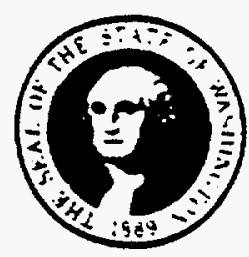

Amendment No. 18

D. Upon departmental request, other permits or documentation required under this license, or state or federal law or regulation.

45. Waste shipments shall not be accepted by the facility uniess the accompanying Form RHF-31 is stamped as received, and initialed by an authorized representative of the deparment. (This individual may be the licensee, when designated by telephone notification and confirming letter from the deparment).

46. Upon acceptance for disposal of each waste shipment, the licensee shall:

A. Acknowiedge receipt of the waste as soon as practicable, but no later than seven days following its acceptance for disposal, by returning a signed copy, or equivalent documentation, of the shipment manifest, to the shipper. The shipper to be notified by the licensee is the one last possessing the waste and transferring it to the licensee.

B. Indicate on the renurned copy of the shipment manifest, shipping papers, or equivalent documentation any discrepancy between noted waste descriptions listed on the manifest or papers and the waste materials received in the shipment.

C. Notify the shipper and the deparment when any shipment or part of a shipment has not arrived 60 days after the separate copy of the shipment manifest or shipping papers was received by the licensee.

D. Maintain copies of completed shipment manifests, including annotations of discrepancies found in accordance with Condition 46.B.

\section{BURIAL OPERATIONS CONDITIONS}

47. Packages containing radioactive material shall not be stored above ground for a period of greater than six months from the date of receipt. Packages shall be stored in such a manner to maintain radiation exposures as low as reasonably achievable. Retention of packaged waste above ground for not more than three working days does not constitute storage.

48. Unless otherwise specifically authorized by the department, the licensee is not authorized to open any package containing radioactive material at the iacility, except for the following: 


\section{State of Washington \\ Radioactive Materials License \\ Page 13 of 36 Pagre

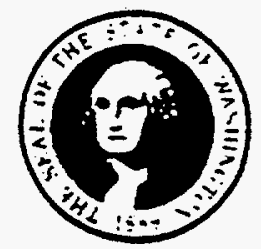 \\ License Numbe \\ W: 1019.2}

Amendment No. 18

t. For purposes of repairing, repackaging, or overpacking leaking containers or containers damaged in transport in the event the material is to be disposed of, or returned to the generator if required for the protection of the health and safery of the employees or the environment.

B. For purposes of inspection and waste confirmation in the presence of a department inspector for compliance with Title 246 WAC, other applicable federal and state regulations, and conditions of this license.

C. For purposes of returaing outer shipping containers.

The licensee shall use and maintain a facility, in accordance with the Facility Standards Manual, where the above operations can be safely conducted.

49. Wastes containing chelating agents in excess of 0.1 percent by weight shall be segregated from other wastes by placing them in disposal units which are sufficiently separated from disposal units for other waste classes so that any interaction between these wastes and other wastes will not affect the radionuclide mobility of the other wastes for 100 years. Until engineering studies provide justification otherwise. minimum separation distance shall be ten feet. In addition to segregation, the licensee shall record the three-dimensional location of these waste cells.

5). Wastes containing solidified oils which have a pretreatment concentration in excess of 10 percent by weight, shall be segregated from other wastes by piacing them in disposai units which are sufficiently separated from disposal units tor other classes ut waste so that any interaction between these wastes and otner wastes wiii not affect the radionuclide mobility of the other wastes for 100 years. Until engineering studies provide justification otherwise, minimum separation distance shall be ten feet. In addition to segregation, the licensee shall record the three-dimensional location of these waste cells.

:1. Class $B$ and $C$ waste packages stabilized with bitumen shall be backfilled immediately after waste placement. Sufficient backfill material shall be placed around each container to cover all sides around the packages. 


\section{State of Washington \\ Radioactive Materials License \\ Page 14 of $36 \quad$ Pege \\ Uanen Number

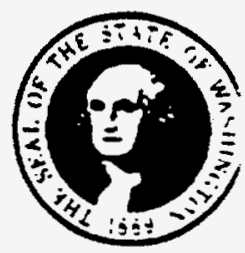

Amendment No. 18

\section{SITE DESIGN AND CONSTRUCTION CONDITIONS}

52. All burial trenches or disposal units shall be in a controlled area surrounded by a chain link fence, eight feet high, and topped with barbed wire.

53. Thirty days prior to commencement of construction of any new disposal unit, the licensee shall submit to the department a detailed engineering plan for the trench in accordance with the provisions of the Facility Standards Manual, or a statement that the proposed trench will be designed and constructed in accordance with Condition 54 of this license.

54. The licensee shall construct new disposal units in accordance with the March 6, 1991 approved Comprehensive Facility Utilization Plan, Document 200-DOC.001, Rev. 3. Changes to the plan must be submitted to the department for review and approval. Additionally, the licensee shall:

A. Upon completion of the construction of any new trench, submit to the department two copies of the trench construction repor. The report shall include at a minimum, as-built drawings, daily and final inspection reports, laboratory and field soil test results, and a description of any problems encountered during construction, in order to demonstrate that the construction of the disposal unit is in compliance with applicable plans and specifications contained in the approved Facility Utilization Plan.

B. 30 days prior to use of any new trench, notify the department in writing of its intent to physically place waste in the trench.

55. The licensee shall conduct closure and stabilization operations in accordance with the March 6, 1991 department-approved Comprehensive Facility Utilization Plan and the Facility Closure and Stabilization Plan required by Condition 66 as each trench is filled and covered.

56. In addition to the requirements of Condition 55, the licensee shall design and construct interim disposal unit caps in accordance with the specifications contained in the Facility Standards Manual. Interim disposal unit caps shall be established within one year of completion of a disposal unit or as described in the Comprehensive Facility Utilization Plan approved by the department. 


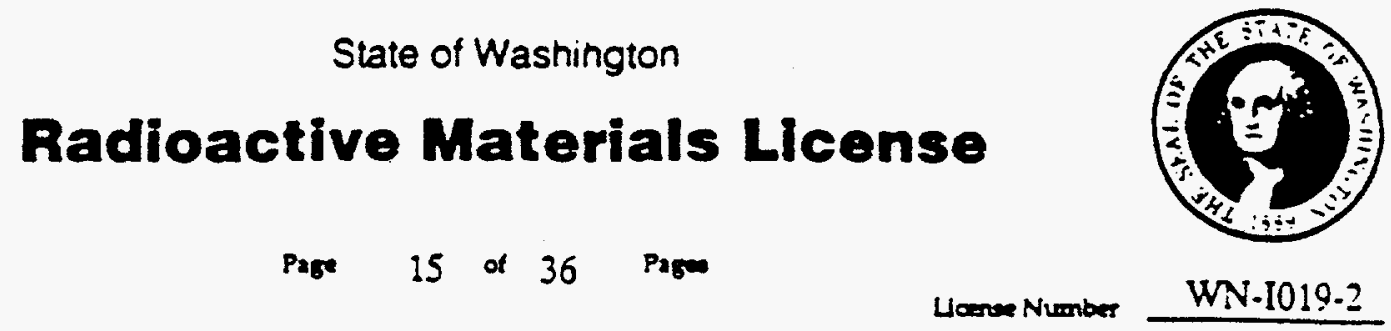

Amendment No. 18

57. The dimensions of burial trenches shall not exceed a width of 150 feet ( 46 meters), a depth of 45 feet (14 meters), or a length of 1000 feet (305 meters) without specific documented approval from the deparment. Measurements shall be referenced to natural grade as established in the March 6, 1991 deparment-approved Comprebensive Facility Utilization Plan.

58. Until an agreement is secured with agencies controlling adjacent lands, which meets the requirements of Condition $66(\mathrm{~K})$ of this license, disposal units constructed after the effective date of this license shall be placed at least 100 feet away from the North, South and West subleasehold boundaries. The set-back distance for the East boundary shall be no less than 50 feet.

59. The licensee shall, within 90 days of filling each disposal unit, closed after the effective date of this license, erect interim disposal unit monuments upon which the following information shall be displayed in a legible manner:

A Total activity of radioactive material, in curies, excluding source and special nuclear materials; total amount of source materials in kilograms; and total amount of special nuclear material in grams.

B. Trench number or disposal unit designation.

C. Date of opening and closing disposal unit.

D. Volume of waste in the disposal unit.

E. Coordinates of the disposal unit.

The erection of interim monuments may be omitted if permanent monuments, required by Condition 65 , are scheduled to be erected within six months of completion of the disposal unit. 


\section{State of Washington \\ Radioactive Materials License}

Page $\quad 16 \propto 36 \quad$ Page

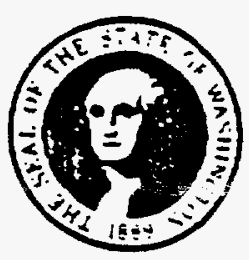

License Number

WN-I019.2

Amendment No. 18

\section{ENVIRONMENTAL MONITORING AND SUR VEY CONDITIONS}

60. The licensee shall perform comprehensive pathway analyses to include air, soil, ground water, vegetation, fauna, burrowing animals, and human impacts, whicb shall be completed within 180 days of a department-approved closure plan. Additionally, the analysis shall be reviewed and updated as necessary every four years subsequent to the approval of the patbway analysis. Upon completion of the review, the licensee stall submit a copy of the review to the department. This requirement is in addition to the requirements found in WAC 246-250-060(1). Within 120 days of completion of the pathway analysis report, the licensee shall submit to the department the licensee's evaluation and analysis of the report with respect to the environmental monitoring programs. The analyses shall clearly identify and differentiate between the roles performed by the natural disposal site characteristics and design features in isolating and segregating the wastes. The analyses shall clearly demonstrate that there is reasonable assurance that the exposure to humans from the release of radioactivity will not exceed the limits set forth in WAC 246-250-170.

61. The liceasee shall conduct an environmental monitoring program capable of detecting the potential contribution of radioactive material from the site to the environment. The program shall include collection of samples and analyses at frequencies specified in the Facility Standards Manual (FSM). The licensee shall coordinate sampling schedules with the department to provide. when possible, duplicate samples on a prearranged frequency. A comprehensive annual report of all sample analyses, with statistical trend analyses and discussions of all anomalous results and actions taken, specification of the quantity of each of the principal contaminants released to unrestricted areas in liquid and in airborne effuents during the preceding year, wind rose for the facility, depth to water and deptb to bottom as well as nonradiological contaminates specified in the FSM, for all ground water wells, ventilation exhaust samples taken from the inspection facility, and comparisons of onsite ground water wells and U.S. DOE ground water wells in the vicinity of the facility shall be forwarded to the department by June 1 of each year. The report shall be submitted in general accordance with the deparments document entitled "Recommended Content and Format for Annual Environmental Reports." Deviations in the reporting format must be approved by the department. In addition, the licensee shall report immediately any environmental monitoring results in excess of reporting levels specified in the Facility Standards Manual. 


\section{State of Washington \\ Radioactive Materials License \\ Page $\quad 17 \propto 36 \quad$ Page

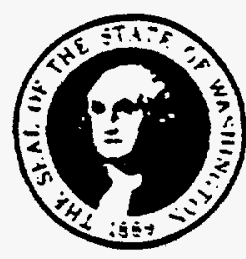 \\ Liaren Number \\ WN-1019-2 \\ Amendment No. 18}

62. The licensee shall conduct an experimental monitoring program designed to determine the extent and modes of migration of disposed waste into the unsanurated zone, in accordance with procedures specifically approved by the department. Annual repors shall be made to the department by June 1, 1993 and June 1 of each year thereafter. The report shall include a discussion of the results of the program.

63. The licensee shall submit a facility utilization report to the deparment by June 30 of each year. The repor shall provide:

A. Identification of each disposal unit and description of all waste emplaced during the previous calendar year. A three-dimensional identification to describe the disposal location of each package of waste in excess of Class A concentrations including the location of engineered barriers used to provide structural stability, and the disposal location of those wastes containing oils or chelates shall also be provided. Three-dimensional identification for cells shall be within 50 feet horizontally and within 10 feet in the vertical plane.

B. Percent of utilization for each operating stable and unstable trench or disposal unit filled during the previous calendar year.

C. Annual aerial photograph of the leasehold.

D. Summary, by waste class, of activities and cuantities of raaionuclides disposed.

E. A summary of disposal unit maintenance activities.

F. Any instances in which observed site characteristics were significantly different from those described in the application for the license.

G. The remaining capacity of the disposal facility and each open disposal unit.

5. Any other information that the department may require. 


\section{State of Washington \\ Radioactive Materials License \\ Page 18 of $36 \quad$ Page

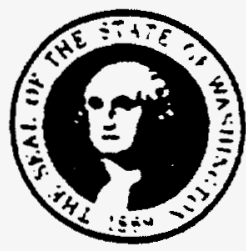 \\ Loene Number \\ IVN-I019-2 \\ Amendment No. 18}

64. As radioactive material buried may not be transferred by abandonment or otherwise, unless specifically authorized by the department, the expiration date of this license applies only to the above-ground activities and to the authority to bury radioactive material wastes at the location specified in Condition 10. The license continues in effect, and the responsibility and authority for possession of buried radioactive material wastes continues until the department finds that the plan established for preparation of the facility for transfer to another person or custodial agency has been satisfactorily implemented in a manner to reasonably assure protection of the public health and safery and the environment, and the department takes action to terminate the licensee's responsibility and authority under this license. All requirements for environmental monitoring, site inspection, maintenance, and site security continue whether wastes are being buried or not.

65. All trenches or disposal units shall be conspicuously marked with permanent, stable monuments at each end, consistent with the approved site closure plan required by Condition 66. Permanent monuments shall be designed to stand erect, well above the grade of the final trench cover, and in a manner which will not allow them to be covered or obscured by drifting sand during the institutional control period. Inscriptions shall be made so as to endure and remain legible well beyond the institutional control period. The permanent monuments shall be inscribed with the following information:

A. Total activity of radioactive material. in curies. exciuding source and special nuclear materials; total amount of source material in kilograms; and total amount of special nuclear material, in grams. in the trench.

B. Trench number or other means of identifying the disposal unit.

C. Date of opening and closing the disposal unit.

D. Volume of waste in the disposal unit.

E. Coordinates of the stable and unstable disposal units, including disposal unit depth and depth of cover at closure.

This same information shall be reported to the Department of Health and the Deparment of Ecology within 30 days of closure of each trench or disposal unit. 


\section{State of Washington \\ Radioactive Materials License \\ Page 19 of $36 \quad$ Pager

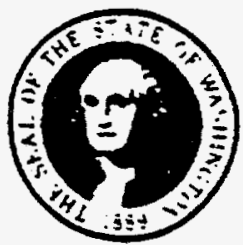 \\ Liones Number WN.I019.2 \\ Amendment No. 18}

06. Upon approval of the Facility Closure and Stabilization Plan dated October 1990, the licensee shall review and update the plan as necessary every four years thereafter. A copy of this review shall be submitted to the department upon completion of the review. The facility closure and stabilization plan shall address how the licensee meets or plans to meet the following requirements:

A. Bury all waste in accordance with the requirements of the license.

B. Dismantle, decontaminate, as required, and dispose of all structures, equipment, and materials that are not to be transferred to the site custodian.

C. Document the arrangements and the status of the arrangements for orderly transfer of site control and for long-term care by the govermment custodian. Also document the agreement, if any, of state or federal governments to participate in or accomplish, performance objectives. Specific arrangements to assure availability of funds to complete the site closure and stabilization plan shail be documented.

D. Direct gamma radiation from buried wastes shall be essentially background at any accessible above-ground location, as determined by evaluation of environmental data from the licensee, U.S. Deparment of Energy, and its contractors.

E. Demonstrate by measurement and model during operations and atter site closure that concentrations of radioactive material which may be released to the general environment in ground water, suriace water, air, soil, plants, or animais will not result in any member of the public receiving an annual dose exceeding an equivalent to 25 millirems $(0.25 \mathrm{mSv})$ to the whole body, 75 millirems ( $0.75 \mathrm{mSv})$ to the thyroid, and 25 millirems $(0.25 \mathrm{mSv})$ to any other organ of any member of the public.

F. Render the site suitable for surface activities without resor to custodial care exceeding vegetation control, minor maintenance, and environmental monitoring. No active ongoing maintenance shall be necessary. Final conditions at the site must be acceptable to the government custodian and compatible with its plan for the site. 


\section{State of Washington \\ Radioactive Materials License \\ Page $20 \propto 36 \quad$ Pagu

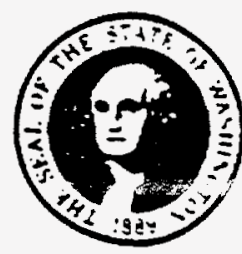 \\ Laren Number WN-I019.2 \\ Amendment No. 18}

G. Demonstrate that all trench elevations are above water table levels, taking into account the complete history of seasonable fluctuations.

H. Eliminate the potential for erosion or loss of site or trench integrity due to factors such as ground water, surface water, wind, subsidence, and frost action. All slopes shall be sufficiently gentle to prevent slumping or gullying. The surface shall be stabilized to minimize erosion, settling, or slumping of caps.

I. Demonstrate that permanent trench markers are in place, stable, and keyed to benchmarks. Identifying information shall be clearly and permanently marked as required by Condition 65 of this license.

J. Compile and transfer to the department complete records of site maintenance and stabilization activities, trench elevation and locations, trench inventories, and monitoring data for use during custodial care for unexpected corrective measures and data interpretation.

K. Maintain a buffer zone to provide space to stabilize slopes, incorporate off-site surface water management features, assure that any future excavation on adjoining areas shall be evaluated as to its potential to compromise trench or site integrity, and provide working space for unexpected mitigating measures, if needed, in the future. The buffer zone may be within the subleasehold or on adjacent land, provided written agreements are secured with persons owning or controlling adjacent lands, which shall allow the licensee or custodial agency the required access and actions.

L Provide a secure passive site security system (e.g., a fence) that requires minimum maintenance.

M. Stabilize the site in a manner to minimize environmental monitoring requirements for the long-term custodial phase, and develop a monitoring program based on the stabilization plan.

N. Investigate the causes of any statistically significant levels of radioactive or hazardous materials in environmental samples taken during operation and stabilization. In particular, any evidence of unusual or unexpected rates or levels of radionuclide migration in or with the ground water shall be analyzed. and corrective measures implemented. 


\section{State of Washington \\ Radioactive Materials License \\ Page 21 of $36 \quad$ Pagm

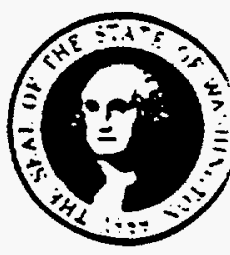 \\ Lioner Number WN-1019.2 \\ Amendment No. 18}

O. Eliminate the need for active water management measures, such as a sump or trench pumping and treatment of water to assure that wastes are not leached by standing water in the trenches.

P. Evaluate present and proposed activities on adjoining areas to determine their impact on the long-term performances of the site, and take reasonable action to identify and minimize the effects.

A final facility closure and stabilization plan shall be submitted for Department of Health approval, following issuance by the Department of Ecology of the final closure and stabilization requirements. This final closure plan shall be submitted within 120 days following acceptance by the Department of Health of Rogers \& Associates' final report on the draft closure plan. The final plan shall address how the licensee meets or plans to meet the requirements developed pursuant to RCW 43.200.190 and recommendations proposed in the Rogers \& Associates final report.

67. The licensee shall develop specific procedures, and implement a program, approved by the department, which is designed to study $A$ ) erosion of soils onto and off of the facility, B) methods of revegetation of closed trenches and, C) subsidence of trenches, in accordance with criteria established by the department. Once adoroved, the i:censee shall submit annual repors to the department winich discusses tne results of the program.

68. Uoon closure of each disposal unit commencing with Trench 14. the licensee shall submut to the deparment a summary of;

A. All radionuclides and associated activities disposed in that trench.

B. Waste class totals by volume and activities.

C. Disposal locations and volume of chelates disposed.

D. A summary to the extent practical, of the physical and chemical forms disposed. 


\section{State of Washington \\ Radioactive Materials License}

Page $22 \propto 36 \quad$ Pagm

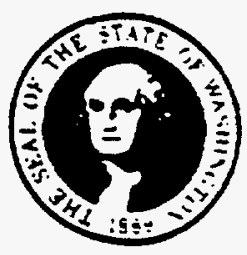

Liane Number

WN-1019.2

Amendment No. 18

69. Norwithstanding other requirements of this license or the sublease, one year prior to the anticipated transfer of the licensee's facility and buried radioactive waste to another person (including an agency of the state or federal government), the licensee shall submit a final version of the facility closure plan, including a schedule for implementation of all remaining plan elements prior to transfer, and a description of the mechanies of orderly transfer in coordination with the transferee.

\section{FINANCIAL ASSURANCES}

70. By June 30 of each year, the licensee shall submit the following financial documentation to the department:

A A copy of its financial report or a certified financial statement and Security and Exchange Commission (SEC) Form 10K.

B. A copy of its financial or surety arrangements for closure and stabilization of the disposal facility.

C. A copy of personnel and nuclear liability insurance held for the facility.

71. The licensee shall submit to the department, a copy of site surveillance fees paid. within 45 days after the end of each calendar quarter.

:2. The licensee shall conduct a quality assurance/quality control program in accordance with US Ecology Quality Assurance Manual, and Quality Assurance Procedures Manual QA-MA-2. Changes to these documents shall be submitted to the department within 30 days of the change. 


\section{State of Washington \\ Radioactive Materials License \\ Page 23 of 36 Pagu

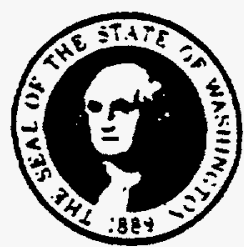 \\ Lane Number \\ WN-I019-2}

Amendment No. 18

73. Except as specifically provided by this license, the licensee shall possess and use radioactive material described in Items 6, 7, and 8 of this license in accordance with statements, representations, and procedures contained in the documents listed below. The deparment's "Rules and Regulations for Radiation Protection," Title 246 WAC, shall govern the licensee's statements in applications or letters, unless statements are more restrictive than the regulations. Any change to the documents listed below shall require deparmental approval in the form of an amendment to this license.

A. Application and cover letter dated September 4, 1991.

B. Facility Standards Manual, Revision 1, dated May 1992.

C. Letter from John Ench, US Ecology, Inc. dated April 9, 1992.

D. Letter from Arthur J. Palmer, US Ecology, Inc., dated December 13, 1991.

Dete_ 29 May 1992

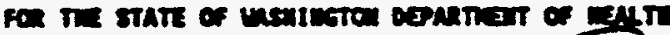

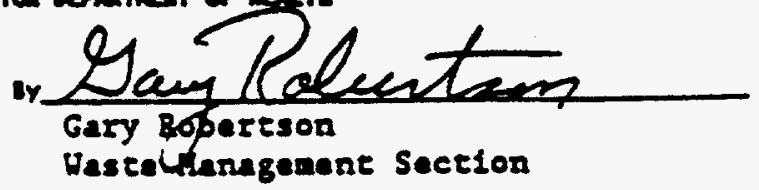


State of Washington

Radioactive Materials License

Page $24 \propto 36$ Pagu

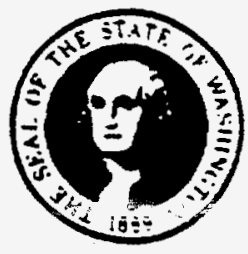

Lante Number

WN-I019.2

Amendment No. 18

APPENDIX A

EXAMPLES* OF CONTANNERS MEETING 7A PERFORMANCE SPECIFICATION

AND HAVING A HEAVY DUTY CIOSURE DEVICE

Spec. 6B Steel Drum (30 gallon)

Spec. 6C Steel Drum (5 and 10 gallon)

Spec. 6J Steel Drum (55 gallon)

Spec. 42B Aluminum Drum (55 gallon)

Spec. 17C Steel Drum (5 gallon)

Spec. 17C Steel Drum (55 gallon)

Spec. 17E Steel Drum (55 gallon)

Spec. 17H Steel Drum (30 gallon)

Spec. $17 \mathrm{H}$ Steel Drum (55 gallon) with $5 / 8^{\text {" bolt closure }}$

Spec. 7A Steel Box (Argonne National Laboratory's Steel Bin)

Spec. 7A Steel Box (BCL-5 Shipping Container)

Spec. 7A Steel Box (Type A Steel Box)

Spec. 7A Steel Drum (Follansbee Drum-MS 24347-2)

Spec. 7A Steel Drum (4 gallon)

- These are merely examples of containers. The waste generator must comply with all DOT requirements pertinent to the container's selection, use, handling and transportation. 
State of Washington

\section{Radioactive Materials License}

$$
\text { Page } 25 \text { of } 36 \text { Pagn }
$$

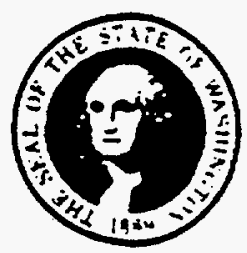

WN.1019-2

Uateen Number

Amendment No. 18

APPENDIX B

WASTE CLASSIFICATION TABLE

RADIONUCLIDES

Table 1 (long-lived)

C. 14

C. 14 in activated metal

Ni-59 in activated metal

$\mathrm{Nb}-94$ in activated metal

Tc-99

i- 129

\section{Class A}

$\leq 0.8$

$\leq 8$

$\leq 22$

$\leq 0.02$

$\leq 0.3$

$\leq 0.008$

\section{Class C}

$\leq 8$

$\leq 80$

$\leq 220$

$\leq 0.2$

$\leq 3$

$\leq 0.08$

\section{CONCENTRATION LMMTS IN NANOCURIES/GRAM}

Alpha emitting Transuranic

$\leq 10$

radionuclides with half-lives greater than five years (excluding special nuclear material) *

Radium 226

Curium 242

Plutonium 241*

$$
\leq 10
$$

$\leq 2,000$

$\leq 350$ $\leq 100$ with specific departmental approval

$\leq 100$ with specific departmental approval $\leq 20,000$ with specific departmental approval

$\leq 3,500$ 


\section{State of Washington \\ Radioactive Materials License \\ Page $26 \propto 36$ Pagm

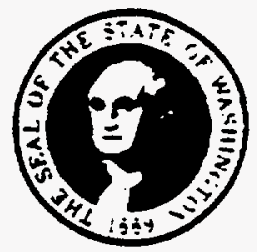 \\ Uame Number \\ WN-1019-2}

Amendment No. 18

APPENDIX B (Cont.)

WASTE CLASSIFICATION TABLE

\section{RADIONUCUIDES}

Table 2 (short-lived)

Total of all with half-life

less than 5 years

H-3

Co-60

$\mathrm{Ni}-63$

$\mathrm{Ni}-63$ in activated metal

Sr-90

Cs-137
CONCENTRATION LIMITS IN CURIES/CUBIC METER"•

Class A Class B Class C

$\leq 700$

$\leq 40$

$\leq 700$

$\leq 3.5$

$\leq 70$

$\leq 700$

$\leq 35$

$\leq 700$

$\leq 7000$

$\leq 0.04$

$\leq 150$

$\leq 7000$

$\leq 1$

$\leq 44$

$\leq 4600$

". Curies/cubic meter is equivalent to microcuries/cubic centimeter

- Although disposal of Special Nuclear Material is covered under Nuclear Regulatory Commission (NRC) license \# 16-19204-01, those radionuclides must be included in any concentration calculation, including the sum of fractions rule.

- There are no limits established for these radionuclides in Class $B$ or $C$ wastes. Practical considerations such as the effects of external radiation and internal heat generation on transportation, handling, and disposal will limit the concentrations for these wastes. These wastes shall be Class B unless the concentrations of other nuclides in Table 2 determine the Waste to be Class $C$ independent of these nuclides. 


\section{State of Washington \\ Radioactive Materials License \\ Page $\quad 27 \propto 36 \quad$ Pago \\ Licene Number

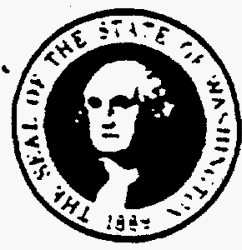 \\ WVi-1019.2}

Amendment No. 18

APPENDIX B (Cont.)

Note 1. Unless specifically restricted elsewhere in the license, the concentration of a radionuclide or radionuclide mixture may be averaged over the volume (or mass) of the waste and, if used, the solidification agent or matrix. The concentration of radionuclides in filters encapsulated with a solidification agent or matrix shall be averaged over the volume of the filter, not the solidification agent. The volume (mass) of packaging containers, liners or overpacks shall not he included in this calculation, nor shall the volume (mass) of the waste mixture be artificially increased by the addition of heavy, nondispersible solids or objects even if considered as waste. Further guidance is provided in "Low-Level Waste Licensing Branch Technical Position on Radioactive Waste Classification," May 1983, or successor documents issued by the U.S. Nuclear Regulatory Commission.

Note 2. The waste is Class $\mathrm{A}$ if none of the listed radionuclides is present. Waste packaged in accordance with Condition 38 of this license shall be Class A unstable and the words "Condition 38 " shall be noted on the manifest or other documentation accompanying the waste package.

Note 3. There are no Class $\mathrm{B}$ values for Table 1 radionuclides: their presence classifies the waste as either Class $A$ or Class $C$ according to their concentrations.

Note 4. The waste class for mixtures of the listed radionuclides is determined by deriving for each radionuclide the ratio berween its concentration in the mixrure and its concentration limit in the table of this and the special nuclear materials license issued by the U.S. Nuclear Regulatory Commission and adding the resulting ratio values for each radionuclide group. All limits used in the calculations must be for the same waste class. The sum of the ratios for each radionuclide group must be equal to or less than 1.0 , or the waste is the next higher classification than that used for the calculation.

If Class $C$ limits are used in the calculation and the sum of ratios for either group exceeds 1.0, the waste is not acceptable for near-surface disposal without prior written approval from the deparment. 
State of Washington

\section{Radioactive Materials License}

$$
\text { Page } 28 \text { of } 36 \quad \text { Page }
$$

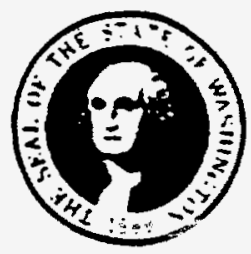

WN-1019.2

Amendment No. 18

\section{APPENDIX B (Cont.)}

Note 5. If radioactive waste contains a mixture of radionuclides, some of which are listed on Table 1, and some of which are listed on Table 2, classification shall be determined as follows:

A. If the concentration of a nuclide listed in Table 1 does not exceed the Class $A$ limit, the class shall be that determined by the concentration of nuclides listed in Table 2.

B. If the concentration of a nuclide listed in Table 1 exceeds the Class A limit, but does not exceed the Class $C$ limit, the waste shall be Class $C$. provided the concentration of nuclides listed in Table 2 does not exceed the Class $\mathrm{C}$ value.

Note 6. If concentrations for any single radionuclide exceed the Class $C$ values in the table, the waste is not acceptable for near-surface disposal under this license. 


\section{State of Washington \\ Radioactive Materials License \\ Page 29 of $36 \quad$ Page

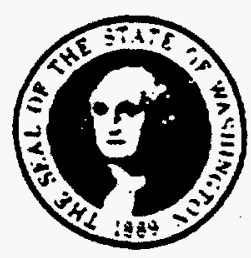 \\ Lamen Nunbe WN-I019.2 \\ Amendment No. 18}

APPENDIX C

APPROVED SOLIDIFICATION MEDIA

Only approved solidification media can be used. Approved solidification media are:

1. Atcor Cement

2. Aquaset I and II

3. Aztech (General Electric)

4. Bitumen" (Waste Chem and ATI)

5. Chem-Nuclear Cement

6. Concrete (Structural)

7. Delaware Custom Media

8. Dow Media

9. Envirostone

10. LN Technologies Porland Cement Formula for Oils

11. Pacific Nuclear Portland Cement

12. Petroset I and II

13. Safe T Set

14. SEG (Westinghouse - Hittman) Cement

15. Other solidification media and processes which have been approved by U.S. NRC and/or the department. 
State of Washington

Radioactive Materials License

Page $30 \propto 36$ Pign

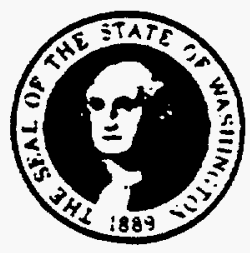

Uaren Number

WN-1019-2

Amendment No. 18

\section{APPENDIX C (Cont.)}

-Note: For waste types that require solidification, both oxidized bitumen and straight distilled are acceptable.

"Solidification" means a resultant waste form which is a free-standing solid and primarily relies upon a chemical reaction or encapsulation to contain the liquid. Approved stabilization media may also be used as solidification agents without conducting tests necessary to verify stability, provided the resulting waste form is a free-standing solid.

It is the responsibility of the person processing the waste into a solid form to adbere to a quality control program to verify the waste form is appropriate. If a material can also be used as a sorbent, the restrictions noted for its use in Appendix $G$ shall apply to its use as a solidification agent. 
State of Washington

\section{Radioactive Materials License}

$$
\text { Page } 31 \propto 36 \text { Pager }
$$

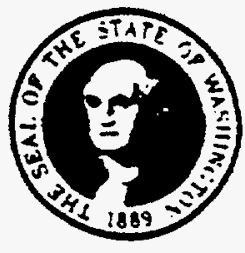

Lom Number WN-1019.2

Amendment No. 18

\section{APPENDIX D}

\section{APPROVED STABILIZATION MEDIA}

Only approved stabilization media may be used. Approved stabilization media are:

1. Aztech (General Electric)

2. Bitumen" (Waste Chem)

3 Concrete:=

4. Dow Media (Vinyl Ester Styrene)

5. Other stabilization media and processes which have been reviewed and approved by U.S. NRC and the department as meeting waste form stability criteria.

-Note: Oxidized Bitumen only.

- Concrete, when used as an encapsulation medium around a small volume of radioactive material, e.g., a sealed source centered in a fifty-five gallon drum containing concrete, shall have a formulated compressive strength greater than or equal to 2500 psi. 


\title{
State of Washington \\ Radioactive Materials License \\ Page $\quad 32 \propto 36 \quad$ Pagu

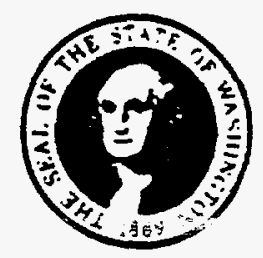 \\ Lianen Number \\ WN.1019.2 \\ Amendment No. 18
}

\author{
APPENDIX E \\ CERTIFICATES OF COMPLLANCE FOR \\ HIGH INTEGRITY CONTAINERS
}

Only those High Integrity Containers which have been approved by the department and used in accordance with the Cerrificate of Compliance $(C$ of $C$ ) may be used. Approved High Integrity Containers are:

$\begin{array}{lll}\text { C of CNumber } & \text { Manufacturer } & \text { Number } \\ \text { WN-HIC-01 } & \text { Pacific Nuclear } & \text { DSHS-HIC-TMI-01 } \\ \text { WN-HIC-02 } & \text { Nuclear Packaging } & \text { DSHS-HIC-EA-50 } \\ \text { WN-HIC-03 } & \text { Chichibu Cement } & \text { DSHS-HIC-SFPIC 200L } \\ \text { WN-HIC-04 } & \text { Chichibu Cement } & \text { DSHS-HIC-SFPIC 400L } \\ \text { WN-HIC-05 } & \text { Nuclear Packaging } & \text { DSHS-HIC-EA 142-A } \\ \text { WN-HIC-06 } & \text { Nuclear Packaging } & \text { DSHS-HIC-EA 50-A } \\ \text { WN-HIC-07 } & \text { Nuclear Packaging } & \text { DSHS-HIC-EA 140-A } \\ \text { WN-HIC-08 } & \text { Nuclear Packaging } & \text { DSHS-HIC-EA 190-A } \\ \text { WN-HIC-09 } & \text { Nuclear Packaging } & \text { DSHS-HIC-EA 210-A } \\ \text { WN-HIC-10 } & \text { Nuclear Packaging } & \text { DSHS-HIC-EA 50-C } \\ \text { WN-HIC-11 } & \text { Nuclear Packaging } & \text { DSHS-HIC-EA 140-C } \\ \text { WN-HIC-12 } & \text { Nuclear Packaging } & \text { DSHS-HIC-EA 142-C } \\ \text { WN-HIC-13 } & \text { Nuclear Packaging } & \text { DSHS-HIC-EA 190-C } \\ & \text { B-140 } & \end{array}$

Package

Identification

Number

DSHS-HIC-TMI-01

DSHS-HIC-EA-SO

DSHS-HIC-SFPIC $200 \mathrm{~L}$

DSHS-HIC-SFPIC $400 \mathrm{~L}$

DSHS-HIC-EA 142-A

DSHS-HIC-EA 50-A

DSHS-HIC.EA 140-A

DSHS-HIC-EA 190-A

DSHS-HIC-EA 210-A

DSHS-HIC-EA SO-C

DSHS-HIC-EA 140-C

DSHS-HIC-EA 142-C

Nuclear Packaging

B-140 
State of Washington

\section{Radioactive Materials License}

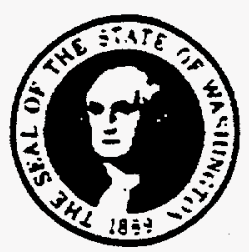

Page $33 \propto 36$ Pagu

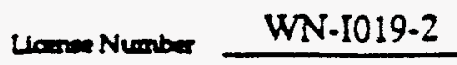

Amendment No. 18

\section{APPENDIX E (Cont.)}

WN-HIC-14

Nuclear Packaging

DSHS-HIC-EA 210-C

WN-HIC-15

(SEG) LN Technologies

DSHS-HIC-LN 179-H

WN-HIC-16

(SEG) LN Technologies

DSHS-HIC-LN 131-H

WN-HIC-17

(SEG) LN Technologies

DSHS-HIC.LN 118-H

WN-HIC-18

(SEG) LN Technologies

DSHS-HIC-LN 96-H

Otber High-Integrity Containers which have been specifically approved by the department. 
State of Washington

\section{Radioactive Materials License}

$$
\text { Page } 34 \propto 36 \quad \text { Pagn }
$$

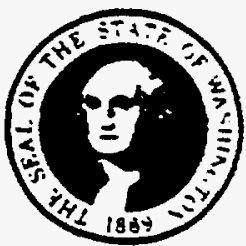

WN-I019-2

Amendment No. 18

\section{APPENDIX F}

Cerificates of Compliance For

Engineered Barriers

Only those Engineered Barriers approved by the department and/or NRC and used in accordance with the Certificate of Compliance ( $\mathrm{C}$ of $\mathrm{C}$ ) may be used. Approved Engineered Barriers are:

C of C Number

WN-EB-01

WN-EB-02
Issued To

US Ecology, Ine.

US Ecology, Inc.

Other Engineered Barriers which bave been specifically approved by the department. 


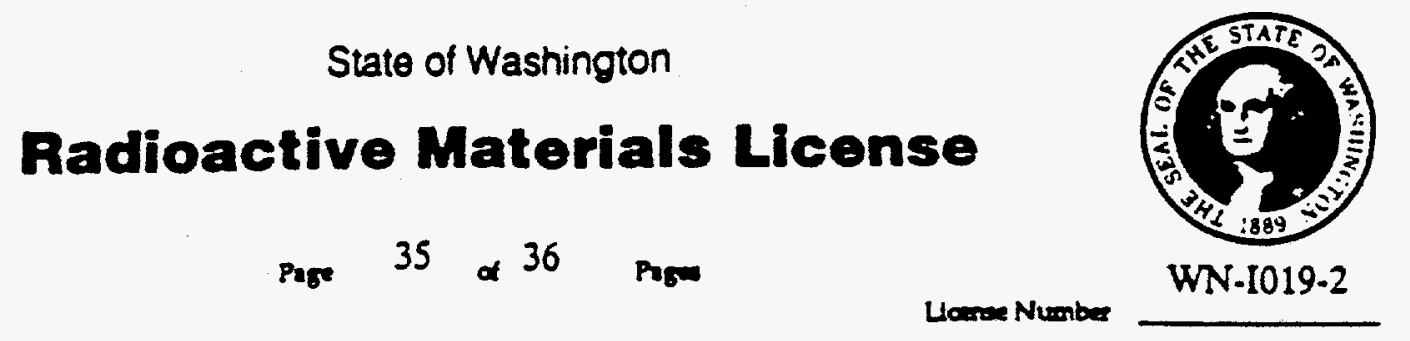

Amendment No. 18

APPENDIX G

\section{APPROVED SORBENTS}

Only those absorbents listed below have been approved by the state of Washington, Department of Health, Division of Radiation Protection, (department) for general use in packaging and/or processing radioactive liquids or with materials that may contain a quantity of liquid that requires absorbing.

Absorbency efficiencies and quantity of absorbent required vary. In all cases, it is the responsibility of the waste generator and/or packager to determine the efficiency and proper proportions of absorbent for liquids being absorbed. Note: Enough absorbent materials must be provided to absorb at least twice the volume of radioactive liquid contents.

Media

A. Clay Materials
Oil

Water
1. Speedi Dri
2 Hi Dri
3. Florco
4. Florco $\mathbf{X}$
5. Instant Dri
6. Safe T Sorb
7. Opalex
8. Moltan Plus

B. Diatomaceous Earths
Approved

Not Approved

Approved

Not Approved

Not Approved

Not Approved

Approved

Approved
Approved

Approved

Approved

Approved

Approved

Approved

Approved

Approved
1. Superfine
2. Floor Dry
3. Celetom
4. Safe N Dri
5. Solid-A-Sorb
6. Ultrasorb 248

Approved
Approved
Approved
Approved
Approved
Approved

Approved Approved Approved Approved Approved Approved 


\section{State of Washington \\ Radioactive Materials License}

$$
\text { Page } 36 \text { a } 36 \text { Pagu }
$$

Lenes Number

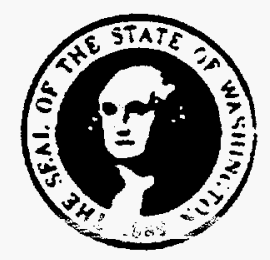

WN-I019-2

Amendment No. 18

\section{APPENDIX G (Cont.)}

Media

C. Perlite $*:=$

1. Chemsil 30

2. Chemsil 50

3. Chemsil 3030

4. Dicaperl HP2OO

5. Dicaperl HPSOO

D. Others
Oil

Water

Not Approved

Approved

Approved

Approved

Approved
Approved

Approved

Approved

Approved

Not Approved
Approved

Approved".:

Approved

Not Approved

Not Approved

Not Approved
Not Approved Approved *e. Not Approved Approved Approved * Approved

- Not for use with pure water

- Note: The products Aquaset, Aquaset II, Petroset, and Petroset II are exempt from Condition 31(B). These products shall only be used without an inner 4 mil plastic liner. Additionally, these products, when used in accordance with the manufacturer's procedures, incorporate the requirement of enough absorbent material to absorb at least twice the volume of radioactive liquid content.

-.. Note: The product Petroset is primarily used in conjunction with Petroset II or Aquaset II when a mixture of water and oils are present and the oils are in excess of five percent of the waste volume. Use of Petroset requires power mixing equipment.

-.e. Note: Perlite products shall not be used for packaging animal carcasses. 


\title{
Additional Requirements for the Disposal of Large Volumes of
}

Naturally Occurring Radioactive Materials (NORM) at the Richland, WA Disposal Facility

\author{
(Washington Administrative Code)
}

WAC 246-249-080 Large rolumes of anturally accurriag material. (1) In eddition to requirements for a disposal site use permit contained in WAC 246-249020. permittees and single senerators of radionctive wastes shall obtain the specific approval of the depart. ment prior to offering wastes for disposal which: (a) Contain naturally occurring radioactive material, excluding source material. (b) conuin an average total concentration less than, or equal to, 0.002 microcuries per gram. and (c) total in excess of 1,000 cubic feet per year.

(2) Applications for specific departmental approval shall describe: (a) The chemical processes which produce of have produced the waste. (b) the volume of waste to be disposed per year, (c) an estimate of bow lons the permittee's disposal needs will continue. (d) actions which have been taken or are planned which could decrease the volume of the waste, and (e) alternative methods of disposal which have been considered by the permittee.

(3) A requeat for specific approval may be approved if the department finds the material to be: (a) Consistent with dispocal site volume utilization, (b) in conformance with conditions of all licenses and permits issued to the disposal site operator. (c) more appropriately disposed at Hanford than by alternative means consistent with the concepts contained in P.L. 99-240 Low Level Radianctive Waste Policy Amendments Act of 1985, and (d) consistent with protection of the public health. safety and environment.

(4) Denial by the department of a request for specific approval shall not be interpreted as an approval to dispoce of naturally cecurring radionctive material without regard to is radionctivity. (Slatulory Authority: RCW 70.98.050 and 70.98.080. 91-16-109 (Order 187). \& 246-249-080, nled 8/7/91, effective 9/7/91. Statutory Authority: RCW 43.70.040. 91-02-049 (Order 121). recodified is $246-249-080$, filed 12/27/90, effective 1/31/91. Sututory Authority: RCW 70.98.080. 87-01031 (Order 2450). \& 402-62-090, filed 12/11/86.] 
DRC-03

August 1989

\section{UTAH DEPARTMENT OF ENVIRONMENTAL QUALITY \\ DIVISION OF RADIATION CONTROL \\ RADIOACTIVE MATERIAL LICENSE}

Pursuant to Section 19-3-104 of the Utah Code Annotated 1953, and the Utah Deparment of Environmental Quality Rules for the Control of Ionizing Radiation, and in reliance of statements and representations heretofore made by the licensee designated below, a license is hereby issued authorizing such licensee to transfer, receive, possess and use the radioactive material designated below; and to use such radioactive material for the purpose(s) and at the placers designated below. This license is subject to all applicable rules, and orders now or hereafter in effect and to an!y conditions specified below.

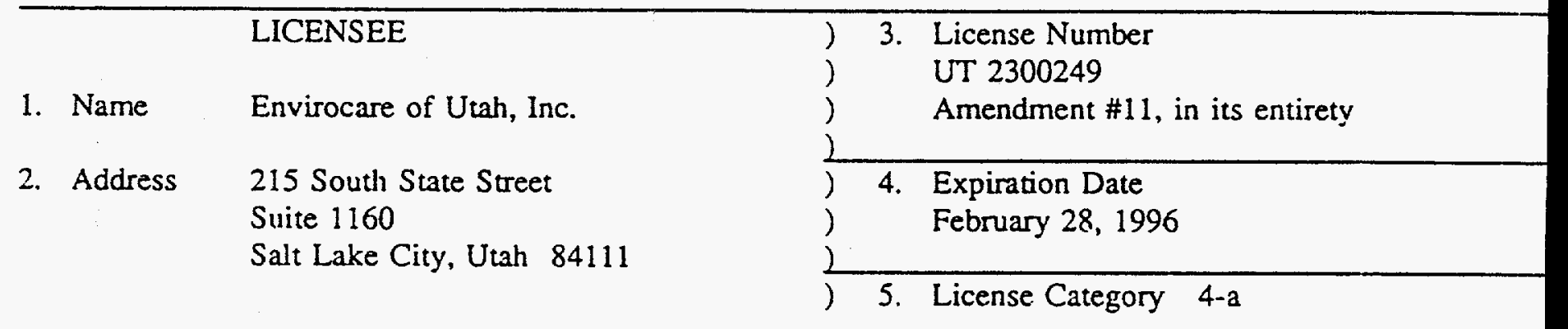

6. Radioactive Material (Element and Mass Number)

A. Silver-110m

B. Americium-241

C. Americium-243

D. Beryllium-7

E. Calcium-45

F. Cadmium-109

G. Cobalt-56

H. Cobalt -57
7. Chemical and/or Physical Form

A. Volumetric bulky materials or structural debris

B. Volumetric bulky materials or structural debris

C. Volumetric bulky materials or structural debris

D. Volumetric bulky materials or structural debris

E. Volumetric bulky materials or structural debris

F. Volumetric bulky materials or structural debris

G. Volumetric bulky materials or structural debris

H. Volumetric bulky materials or structural debris
8. Maximum Concentration in Waste for Dispesi:

A. $\quad 5.6 \mathrm{E}+02 \mathrm{pCi} / \mathrm{g}$

B. $2.3 \mathrm{E}+02 \mathrm{pCi} / \mathrm{E}$

C. $\quad 1.7 \mathrm{E}+03 \mathrm{pCi} / \mathrm{g}$

D. $3.8 E+04 \bar{\mu} \mathrm{Ci} / 9$

E. $\quad 4.0 \mathrm{E}+108 \mathrm{pC}^{\prime} \tilde{\varepsilon}$

F. 4.6́ $+04 \mathrm{pCi} / \mathrm{g}$

G. $\quad 3.6 \mathrm{E}+02 \mathrm{pCi} / \mathrm{g}$

H. $\quad 1.9 \mathrm{E}+04 \mathrm{pCi} / \mathrm{g}$

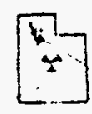

B-146 
DRC-03

August 1989

UTAH DIVISION OF RADIATION CONTROL

Page 2 of 12

RADIOACTIVE MATERIAL LICENSE

SUPPLEMENTARY SHEET

License \# UT 2300249

6. Radioactive Material (Element and Mass Number)

I. Cobalt-58

J. Cobalt -60

K. Chromium-51

L. Cesium-134

M. Cesium-137

N. Europium-152

O. Europium-154

P. Iron-55

Q. Mercury-203

R. Potassium-40

S. Iridium-192

T. Manganese-54
7. Chemical and/or Physical Forn

I. Volumetric bulky materials or structural debris

J. Volumetric bulky materials or structural debris

K. Volumetric bulky materials or structural debris

L. Volumetric bulky materials or structural debris

M. Volumetric bulky materials or structural debris

N. Volumetric bulky materials or structural debris

O. Volumetric bulky materials or structural debris

P. Volumetric bulky materials or structural debris

Q. Volumetric bulky materials or structural debris

R. Volumetric bulky materials or structural debris

S. Volumetric bulky materials or structural debris

T. Volumetric bulky materials or structural debris
8. Maximum Concentration In Waste for Disposal

I. $\quad 1.6 \mathrm{E}+03 \mathrm{pCi} / \mathrm{g}$

J. $\quad 3.6 \mathrm{E}+02 \mathrm{pCi} / \mathrm{g}$

K. $\quad 6.8 \mathrm{E}+04 \mathrm{pCi} / \mathrm{g}$

I. $\quad 1.2 \mathrm{E}+03 \mathrm{pCi} / \mathrm{g}$

M. $\quad 5.6 \mathrm{E}+02 \mathrm{pCi} / \mathrm{g}$

N. $\quad 1.7 \mathrm{E}+03 \mathrm{FCi} / \mathrm{g}$

ก. $\quad 1.4 \mathrm{E}+03 \mathrm{pCi} / \mathrm{g}$

P. $\quad 1.8 \mathrm{E}+06 \mathrm{pCi} / \mathrm{gg}$

Q. $\quad 1.0 \mathrm{E}+04 \mathrm{pCi} / \mathrm{g}$

R. $\quad 1.0 \mathrm{E}+04 \mathrm{pCi} / \mathrm{g}$

S. $\quad 2.5 \mathrm{E}+03 \mathrm{pCi} / \mathrm{g}$

T. $\quad 5.6 \mathrm{E}+03 \mathrm{pCi} / \mathrm{g}$

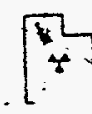

B-147 
DRC-03

August 1989

UTAH DIVISION OF RADIATION CONTROL

Page 3 of 12

RADIOACTIVE MATERIAL LICENSE

SUPPLEMENTARY SIEET

License \# UT 2300249

6. Radioactive Material

(Element and Mass Number)

U. Niobium-94

V. Nickel-59

W. Nickel-63

X. Lead-210

Y. Polonium-210

Z. Radium-226

AA. Radium-228

BB. Radium-228

1 year

CC. Radium-228

5 years

DD. Radium-228

10 years

EE. Ruthenium-106

FF. Antimony-124
7. Chemical and/or Physical Form

U. Volumetric bulky materials or structural debris

V. Volumetric bulky materials or structural debris

W. Volumetric bulky materials or structural debris

X. Volumetric bulky materials or structural debris

Y. Volumetric bulky materials or structural debris

Z. Volumetric bulky materials or structural debris

AA. Volumetric bulky materials or structural debris

BB. Volumetric bulky materials or structural debris

CC. Volumetric bulky materials or structural debris

DD. Volumetric bulky materials or structural debris

EE. Volumetric bulky materials or structural debris

FF. Volumetric bulky materials or structural debris

\section{Maximum Concentration in Waste for Disposal}

U. $\quad 1.6 \mathrm{E}+02 \mathrm{pCi} / \mathrm{g}$

V. $\quad 7.0 \mathrm{E}+02 \mathrm{pCi} / \mathrm{g}$

W. $\quad 2.0 \mathrm{E} \div 06 \mathrm{pCi} / \mathrm{g}$

X. $2.3 \mathrm{E}+05 \mathrm{pCi} / \mathrm{g}^{*}$

Y. $\quad 2.0 \mathrm{E}+04 \mathrm{pCi} / \mathrm{g}$

Z. $2.0 \mathrm{E}+03 \mathrm{pCi} / \mathrm{g}^{*}$

AA. $\quad 1.8 \mathrm{E}+03 \mathrm{pCi} / \mathrm{g}$

BB. $1.2 E+03 \mathrm{pCi} / \mathrm{g}^{*}$

CC. $\quad 6.7 \mathrm{E}+02 \mathrm{pCi} / \mathrm{g}^{*}$

DD. $\quad 5.6 \mathrm{E}+02 \mathrm{pCi} / \mathrm{g}^{*}$

EE. $\quad 1.9 \mathrm{E}+04 \mathrm{pCi} / \mathrm{g}^{*}$

FF. $\quad 7.9 \mathrm{E}+02 \mathrm{pCi} / \mathrm{g}$

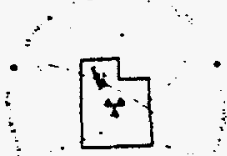

B-148 
DRC-03

August 1989

UTAH DIVISION OF RADIATION CONTROL

Page 4 of 12

\section{RADIOACTIVE MATERIAL LICENSE}

SUPPLEMENTARY SHEET

License \# UT 2300249

6. Radioactive Material

(Elcrnent and Mass Numixur)

GG. Antimony-125

HH. Tin-113

II. Strontum-90

JJ. Thorium-230

KK. Thorium-232

LL. Uranium-234

MM. Uranium-235

NN. Uranium-236

00. Uranium-238

PP. Uranium-natural

QQ. Uranium-depleted

RR. Zinc-65
7. Chemical and/or Physical Form

GG. Volumetric bulky materials or structural debris

HH. Volumetric bulky materials or structural debris

II. Volumetric bulky materials or structural debris

JJ. Volumetric bulky materials or structural debris

KK. Volumetric bulky materials or structural debris

LL. Volumetric bulky materials or structural debris

MM. Volumetric bulky materials or structural debris

NN. Volumetric bulky materials or structural debris

OO. Volumetric bulky materials or structural debris

PP. Volumetric bulky materials or structural debris

QQ. Volumetric bulky materials or structural debris

RR. Volumetric bulky materials or structural debris
8. Maximum Concentration In

Waste for Disposal

GG. $5.3 \mathrm{E}+03 \mathrm{pCi} / \mathrm{g}$

HH. 7.3E+05 pCi/g

II. $2.0 \mathrm{E}+04 \mathrm{pCi} / \mathrm{g}$

JJ. $\quad 1.5 \mathrm{E}+04 \mathrm{pCi} / \mathrm{g}$

KK. 6.8E+02 pCi/g*

LL. 3.7E+04 pCi/g

MM. 7.7E $+02 \mathrm{pCi} / \mathrm{g}$

NN. $\quad 3.6 \mathrm{E}+04 \mathrm{pCi} / \mathrm{g}$

oO. 2.8E+04 pCi'g

PP. $\quad 1.8 \mathrm{E}+04 \mathrm{pCi} / \mathrm{g}$

QQ. $\quad 1.1 E+05 \mathrm{pCi} / \mathrm{g}$

RR. 1.1E+04 FCi/g

Daughters are assumed to be present at same concentrations in equilibrium.

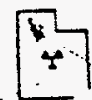

B-149 
DRC-03

August 1989

UTAH DIVISION OF RADIATION CONTROL

Page $\underline{5}$ of $\underline{12}$

\section{RADIOACTIVE MATERIAL LICENSE}

SUPPLEMENTARY SHEET

License \# UT 2300249

\section{AUTHORIZED USE}

Radioactive material as radioactive waste may be received, stored and disposed of by land burial. The licensee shall not accept low-level radioactive waste generated outside the region comprised of the party states to the Northwest Interstate Compact on Low-Level Radioactive Waste Management ("Compact") namely Alaska, Hawaii, Idaho, Montana, Oregon, Utah and Washington, unless the provisions of Articles $I V$ and $V$ of the Compact are met. Prior to receiving any such shipments, the licensee shall submit to the Utah Division of Radiation Control documentation evidencing compliance with these Compact provisions.

\section{CONDITIONS}

10. Licensed material shall be used at the licensee's facility located in Section 32 of Township 1 South and Range 11 West, Tooele County, Utah.

11. The licensee shall not possess at any time, more than 300,000 cubic yards of radioactive waste material which is not disposed of in accordance with the finished design requirements. This includes all wastes in storage or active processing.

12. Plisuant to R447-12-54(1), the licensec is granted as excmption to R447-25-9, as it relates to land ownership and assumption of ownership.

13. The maximun quantity of special nuclear material which the licensee may possess, undisposed of, at any one time shall not exceed 350 grams of U-235.

14. Licensed material specified in Item 6.A through 6.RR shall not be placed in a disposal cell unless it has bsen determined that the concentration of radionuclides is appropriately homogeneous within the physical form of the waste. This does not pertain to structural debris superficially contaminated with licensed materials.

15. A. If a mixture of radionuclides $a, b$, and $c$ are present in the waste in the concentrations $C_{2}, C_{b}$, and $C_{c}$ and if the applicable maximum waste concentrations from Item 8 of this license are $M W C_{a}, M W C_{b}$, and $M W C_{c}$ respectively, then the concentration in the waste shall be limited so that the following relationship exist.

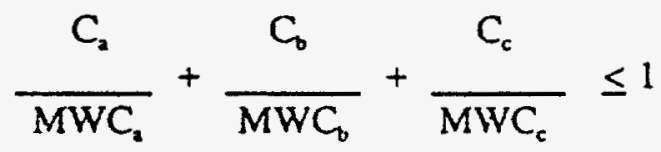

B. If a single radionuclide is present in the waste, the concentration shall not exceed the applicable value found in Item 8 of this license.

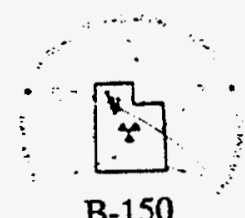




\section{UTAH DIVISION OF RADIATION CONTROL RADIOACTIVE MATERIAL LICENSE SUPPLEMENTARY SHEET}

6. A. The licensee may receive for treatment, storage, and disposal any radioactive waste as authorized by this license that contains hazardous constituents as permitted by the "RCRA Hazardous Waste Operations Permit" issued by the Executive Secretary, Utah Solid and Hazardous Waste Committee and "HWSA Permit" issued by the U.S. Environmental Protection Agency.

B. The licensee shall dispose of these wastes in the "mixed waste" disposal embankment only.

17. Sealed sources as defined in R447-12-3(64) shall not be accepted for disposal.

18. Radioactive waste containing liquid, shall not be accepted for disposal except as provided by the Ground Water Discharge Permit, number UGW 450005, issued by the Executive Secretary of the Utah Water Quality Board.

19. The licensee shall comply with the provisions of Chapter R447-18, "Notices, Instructions and Reports to Workers by Licensees or Registrants, Inspections" and Chapter R447-15, "Standards for Protection Against Radiation".

20. The licensee may transport licensed material or deliver licensed material to a carrier for transport in accordance with the provisions of R447-19-100 "Transportation".

21. Written procedures shall be maintained and available at the disposal facility for operations involving radioactive materials. The procedures shall incorporate operating instructions and appropriate safety precautions for the work. The employee training program shall include detailed review of the operating procedures applicable to the employee's assignments. The requirement for written procedures shall include establishment of procedures for conduct of the radiation safety and environmental monitoring programs, including analytical procedures and insurument calibration requirements. Written procedures and subsequent changes to the procedure shall be reviewed and approved by the Corporate Radiation Safety Officer and the Project Manager. At least annualiy, all procedures shall be reviewed to assure continued applicability.

22. The Corporation Radiation Safety Officer shall perform and document weekly inspections of the facility and report any findings of non-compliance, affecting radiological safety, to the Project Manager. Iterns for inspection include: operating procedures, license requirements and safety practices.

23. The licensee shall conduct contamination surveys in accordance with Table 7.2 of the license amendment application dated September 20, 1990.

24. The licensee shall conduct a bioassay and occupational airborne radioactive contamination monitoring program in accurdance with Section 7.4 .8 .3 of the license amendment application dated September 20, 1990.

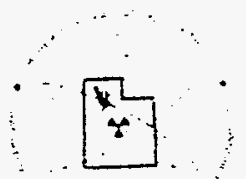

B-151 
DRC-03

August 1989

\section{UTAH DIVISION OF RADIATION CONTROL RADIOACTIVE MATERIAL LICENSE SUPPLEMENTARY SHEET}

25. The use of respirators shall be controlled by a respiratory protection program as stipulated in R447-15-103.

26. The licensee shall calibrate air sampling equipment at intervals not to exceed six months.

27. The operational environmental monitoring program shall be conducted in accordance with Section 4.5, Table 4.7 and Figure 4.6 of the license amendment application dated September 20, 1990.

28. Vehicles, facilities, equipment or other items for unrestricted use shall not be released from the licensee's control if contamination measurements exceed the following limits:

Nuclide
U-nat, U-235, U-238, and associated
decay products
Transuranics, Ra-226, Ra-228. Th-230.
Th-228, Pa-231, Ac-227, I-125, I-129
Th-nat. Th-232, Sr. 90 . Ra-223, Ra-224,
U-232, I-i26, I-13i, I-133
Beta-gamma emitters (nuclides with decay
mocies other than alpha emissions or
spontaneous fission) exceps Sr-90 and other
noted above.

$$
\begin{aligned}
& \text { Colunn I } \\
& \text { Average }{ }^{8, s,} \\
& 5,000 \mathrm{dpm} \text { alpha/ } \\
& 100 \mathrm{~cm}^{2} \\
& 100 \mathrm{dpm} / 100 \mathrm{~cm}^{2} \\
& 1,000 \mathrm{dpm} / 100 \mathrm{~cm}^{2} \\
& 5,000 \mathrm{dpm} \text { beta, }
\end{aligned}
$$
gamma/100 $\mathrm{cm}^{2}$
Column II

Maximum bes

15,000 dpm alpha/ $100 \mathrm{~cm}^{2}$

$300 \mathrm{dpm} / 100 \mathrm{~cm}^{2}$

$3,000 \mathrm{dpm} / 100 \mathrm{~cm}^{2}$

15,000 dpm betagamma $/ 100 \mathrm{~cm}^{2}$

\author{
Column III \\ Removable ses \\ 1,000 dpm alpha \\ $100 \mathrm{~cm}^{2}$ \\ $20 \mathrm{dpm}^{\prime} 100 \mathrm{~cm}^{2}$ \\ $200 \mathrm{dpm} / 100 \mathrm{~cm}^{2}$ \\ 1,000 upm beta- \\ gamms $1(x) \mathrm{cts}^{2}$
}

3. Where surface contamination by both aipha- and beta-gamma cmitting nuclides exists, the limits established for alpha- and beta-gamma erairting nuclides should apply independenuly.

b. As used in this table, dpri (disintegrations per minute) means the rate of emission by radioactive material as determinet by correcting the cownts per ininute observed by an appropriate detector for background, efficiency, and geometric factors associated with the instrumentaliun.

c. Measurements of average contaminant should not be averaged over more than one square meter. For objects of iess suriace area the average should be derived for each such object.

d. The maximurn contamination level applies 10 an area of not more than $100 \mathrm{~cm}^{2}$.

e. The amount of removable radioactive material per $100 \mathrm{~cm}^{2}$ of surface area should be determined by wiping the area with dry filter or soft absorbent paper, applying moderate pressure, and assessing the amount of radioactive material on the wipe with an appropriate instrument of know efficiency. When rcmovable contamination on objects of less surface area is detemined. the peninent levsts sheuld be reduced proporionally and tise enlire surtace should be wiper.

f. The average and maximum radiation levels associated with surface contamination resulting from beta-gamma emitiers shall not excecd 0.2 mradhr at $1 \mathrm{~cm}$ and $1.0 \mathrm{mrad} / \mathrm{hr}$ at $1 \mathrm{~cm}$, respectively, measured through not more than 7 milligrams per square centimeter of toial ebsortier.

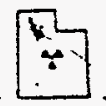


DRC-03

August 1989

UTAH DIVISION OF RADIATION CONTROL

Page $\underline{8}$ of 12

RADIOACTIVE MATERIAL LICENSE

SUPPLEMENTARY SHEET

License \# UT 2300249

29. A quarterly report shall be prepared by the Corporate Radiation Safety Officer for the Project Manager and Company President evaluating employee exposures, effluent releases and environmental data to determine:

A. If there are any upward trends in personnel exposures for identifiable categories of workers or types of operations or in effluent releases;

B. If exposures and effluents might be lowered under the concept of maintaining exposures and effluents as low as reasonably achievable; and

C. If equipment for exposure and effluent control is being properly used and maintained.

30. In accordance with R447-25-33, the licensee shall submit annual reports to the Division of Radiation Contrul by the end of the first calendar quarter of each year for the preceding year. The reports shall include:

A. Specification of the quantity of each of the principal contaminants released to unrestricted areas in liquid and in airborne effluents during the preceding year.

B. The results of the environmental monitoring program:

C. A summary of licensee disposal unit survey and maintenance activities; and

D. A summary of the volume, radioisotopes and their activities for materials disposed of.

31. Except as provided by this condition, the licensee shall maintain the results of sampling, analyses, surveys, and instrument calibration, reports on inspections and audits, employee training records as well as any related reviews, investigations and corrective actions, for five (5) years. The licensee shall maintain personnel exposure records in accordance with R447-15-401.

32. Operations shail be conducted by or under the supervision of Vernon E. Andrews, Corporate Radiation Safely Officer, or other individuals designated by the Corporate Radiation Safety Officer upon successful completion of the licensee's training program.

33. The licensee shall staff the operations of the facility in accordance with the organization chart (Figure 8.1) of the license amendment application dated September 20, 1990.

34. The licensee staff shall meet the qualifications as described in Section 8.2 and shall have the responsibilities as described in Section 8.1.2 of the license amendment application dated September 20, 1990.

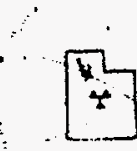

B-153 


\section{UTAH DIVISION OF RADIATION CONTROL RADIOACTIVE MATERIAL LICENSE SUPPLEMENTARY SHEET}

35. The licensee shall not initiate disposal operations in newly excavated areas until the Division of Radiation Control has inspected and approved the cell/embankment liner.

36. The licensee shall provide "as built drawings" of the facility, at intervals not to exceed six (6) months. Drawings shall be submitted by February 1 and August 1 of each year. The drawings shall show conditions on the site as they existed no earlier than thirty (30) days prior to the submittal of the drawings to the Division of Radiation Control. Drawings submitted as, "as built drawings" will be marked as such, and will be marked in the same place on each drawing. Record drawings showing approved future designs, final or finished conditions at the site may be included in the "as built drawings", but shall be marked as "record drawings".

37. Radioactive waste which have been off loaded shall be placed in the appropriate disposal embankment and stored in a manner approved by the Division of Radiation Control.

38. For the purpose of this license, debris is defined as any radioactive waste for disposal other than soils. Compactible debris is-defined as: (A) having a gradation that will pass through a four inch (4") grizzly and; (B) as having a density greater than seventy pounds per cubic foot dry weight in accordance with ASHTO T-09. Contaminated materials, other than soil, not meeting these criteria are defined as noncompactible debris.

39. The licensee shall place bulk radioactive materials in twelve inch (12") uncompacted lifis.

40. In-place bulk radioactive waste shall be compacted at a moisture content of zero percent $(0 \%)$ to three percent (3\%) of optimum as determined by the Standard Proctor Method ASTM D-698.

41. The licensee shall compact each lift to not less than ninety percent (90\%) of optimum density as determined by Standard Proctor Method ASTM D-698. Sampling points for compaction testing shall include locations immediately adjacent to debris when debris is included in the lift.

42. All debris shall be less than ten inches (10") in at least one (1) dimension, and no longer than eight feet ( $\left.8^{\prime}\right)$ in any dimension.

43. The final 24 inches of the radioactive waste material embankment, within the side slopes and the top surface, shall be free of debris.

44. A lift or any portion of a lift shall be limited to less than ten percent (10\%) by volume of noncompactible debris and the debris shall be uniformly distributed throughout the lift. However, noncompactible debris in the form of concrete, stone or solid metal may be placed in the lift up to twenty-five percent (25\%) by volume, of the totil lift if uniformly distributed throughout the lift.

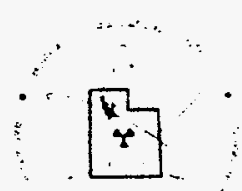

B-154 
DRC-03

August 1989

UTAH DIVISION OF RADIATION CONTROL

Page 10 of 12

\section{RADIOACTIVE MATERIAL LICENSE}

SUPPLEMENTARY SIIEET

License \# UT 2300249

45. The licensee shall excavate the disposal ceil liner, consisting of native materials, to a depth of twenty-four inches (24") and replace it with imported clay in six inch (6") uncompacted lifts. Each lift shall be compacted to not less than ninety-five percent (95\%) optimum density as determined by ASTM D-698 and field permeability of $1.0 \times 10^{-7} \mathrm{~cm} / \mathrm{sec}$.

46. The licensee shall not place, compactible nor non-compactible debris, in the first lift.

47. The disposal cell liner and radon barrier shall be constructed with a moisture content of zero percent $(0 \%)$ to three percent (3\%) of optimum moisture as determined by Standard Proctor Method ASTM D-698.

48. The licensee shall compact the radon barrier to not less than 95 percent of optimum density as determined by Standard Proctor Method ASTM D-698 and a field permeability of $1.0 \times 10^{-7} \mathrm{~cm} / \mathrm{sec}$.

49. The licensee shall record, at the time of acceptance, the date and time of day that any lift or portion of a lift has been accepted by the licensee as finished in accordance with all specifications and license conditions.

50. The licensee shall use rock filter zone and rock erosion barrier that has been sized and graded in accordance with Section 3.1.1.2 and 9.2.5 of the license amendment apuilication dated September 20, 1990.

51. The licensee shall test rock erosion barrier and filter zone rock in accordance with the provisions found in Section 9 of the license amendment application dated September 20, 1990.

52. The licensee shall utilize a manifest ("Radioactive Waste Shipment and Disposal Record," Envirocare Fonn E$100)$ containing the information required in R447-15-3!1(2) and (3) including:

A. Specification of any solidification agents utilized;

B. Identification of wastes containing more than $0.1 \%$ by weight of chelating agents. Chelating agents mears amine polycarboxylic acids, hydroxyl-carboxylic acids, gluconic acids and polycarboxylic acids;

C. An estimate of the weight percentage of any chelating agents in waste.

53. The licensee shall not accept radioactive waste for storage and disposal unless the licensee has received a complete "Radioactive Waste Shipment and Disposal Record" (Form \#E-100) from the shipper.

54. The licensee shall mainiain copies of complete manifests or equivalent documentation until the Division of Radiation Control authorizes their disposition.

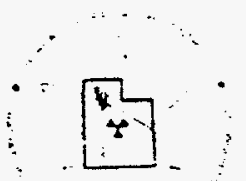

B-155 
DRC-03

August 1989

UTAH DIVISION OF RADIATION CONTROL

Page 11 of 12

\section{RADIOACTIVE MATERIAL LICENSE \\ SUPPLEMENTARY SHEET}

License \# UT 2300249

55. The licensee shall immediately notify the Division of Radiation Control or the Division's on-site representative of any waste shipment where a violation of applicable regulations or license conditions has been found.

56. The licensee shall require anyone who transfers radioactive waste to the facility comply with the requirements in R447-15-311(4)(a) through (h).

57. The licensee shall acknowledge receipt of the waste within one (1) week of receipt by retuming a signed copy of the manifest or equivalent documentation to the shipper. The shipper to be notified is the licensee who last possessed the waste and transferred the waste to the licensee. The returned copy of the manifest or equivalent documentation shall indicate any discrepancies between materials listed on the manifest and materials received.

58. The licensee shall notify the shipper (i.e., the generator, the collector, or processor) and the Division of Radiation Control when any shipment or part of a shipment has not arrived within 60 days after the advance manifest was received.

59. The licensee shall maintain a record for each shipment of waste disposed of at the site. As a mininum, the record shall include:
A. The date of disposal of the waste;
B. The location of waste in the disposal site;
C. The condition of the waste packages received;
D. Any aiscrepancy between the waste listed on the shipment manifest or shipping papers and the waste received in the shipment.
E. A description of any evidence of leaking or damaged packages or radiation or contamination in excess of applicable regulatory limits; and
D. A description of any repackaging operations of any of the waste packages in the shipment.

60. In accordance with R447-25-31 the licensee shall maintain a Utah Division of Radiation Control Surety (Trust) Agreement adequate to fund the decommissioning and reclamation of the grounds, equipment and facilities. These costs, identified in Section 10 of the license amendment afplication dated September 20, 1990, shail be reviewed and updated annually and a report submitted to the Utah Division of Radiation Control within 60 days after July 1, of each year. The survey arrangement shall be updated as necessary to reflect decommissioning and reclamation costs.

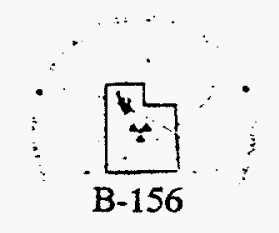


61. Truck, railcar, waste hauling and other earth moving equipment washdown (decontamination) facilities, including evaporation ponds, shall be controlled and fenced to prevent intrusion.

62. All burial embankments and waste storage areas, including immediately adjacent drainage structures, shall be controlled areas, surrounded by a six foot (6') high, chain link fence, topped with twisted selvedge. All permanent fence shall be chain link, six feet (6') high, topped with three strand barbed wire, top tension wire and twisted selvedge.

63. The licensec shall fulfill and maintain compliance with all conditions and shall meet all compliance schedules stipulated in the Ground Water Discharge Permit, number UGW 450005, issued by the Executive Secretary of the Utah Water Quality Board.

64. One (1) year prior to the anticipated closure of the site, the licensee shall submit a final version of the site closure, decontamination and decommissioning plan. As part of this plan, the licensee shall demonstrate by measurements and/or modeling that concentrations of radioactive materials which may be released to the general environment, after site closure, will not result in an annual dose exceeding 25 millirems to the whole body, 75 millirems to the thyroid, and 25 millirems to any other organ of anj member of the public.

65. Except as specifically provided otherwise by this license, the licensee shall possess and use radioactive material described in Item 6,7 , and 8 of this license and conduct site operations in accordance with statements, representations, operating procedures, and disposal criteria, heretofore made by the licensee or his authorized representative in application for and subsequent to issuance of Utah Radioactive Material License No. UT 2300249 and amendmients thereto.

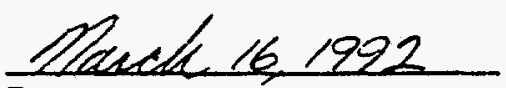

Date

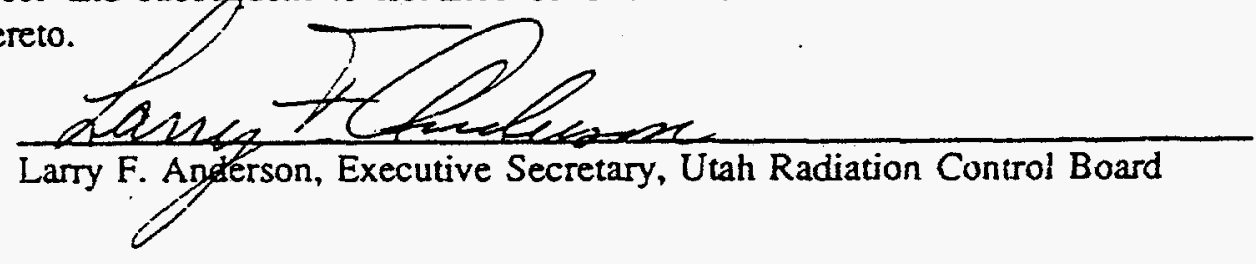




\section{TAH DEPARTMENT OF ENVIRONMENTAL QUALITY DIVISION OF RADIATION CONTROL RADIOACTIVE MATERIAL LICENSE}

License \# UT 2300249

Amendment \# 12

Envirocare of Utah, Inc.

215 South State Street

Suite 1160

Salt Lake City, Utah 84111

In accordance with letter dated October 27, 1992, radioactive material license number UT 2300249 is amended as follows:

\section{CONDITION 28.}

28. A. Vehicles, containers, facilities, materials, equipment or other items for unrestricted use, except rail cars, trucks and trailers used for commercial transport of radioactive waste material, shall not be released from the licensee's control if contamination exceeds the limits found in Table 28-A:

TABLE 28 - A

Nuclide*

U-nat, U-235, U-238, and associated decay products

Transuranics, Ra-226, Ra-228, Th-230, Th-228, Pa-231, Ac-227, I-125, I-129

Th-nat, Th-232, Sr-90, Ra-223, Ra-224, U-232, I-126, I-131, I-133

Beta-gamma emitters (nuclides with decay modes other than alpha emissions or spontancous fission) except Sr-90 and other noted above.
Column I

Average bes

5,000 dpm alphal $100 \mathrm{~cm}^{2}$

$100 \mathrm{dpm} / 100 \mathrm{~cm}^{2}$

$1,000 \mathrm{dpm} / 100 \mathrm{~cm}^{2}$

5,000 dpm beta. 8 amma/100 $\mathrm{cm}^{2}$
Column II Maximum *as

15,000 dpm alpha/ $100 \mathrm{~cm}^{2}$

$300 \mathrm{dpm} / 100 \mathrm{~cm}^{2}$

$3,000 \mathrm{dpm} / 100 \mathrm{~cm}^{2}$

15,000 dpm betagamma/100 $\mathrm{cm}^{2}$
Column III

Removable ves

1,000 dpm alphal $100 \mathrm{~cm}^{2}$

$20 \mathrm{dpm} / 100 \mathrm{~cm}^{2}$

$200 \mathrm{dpm} / 100 \mathrm{~cm}^{2}$

1,000 dpm betagamma/100 $\mathrm{cm}^{2}$

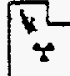

B-158 


\section{ITAH DIVISION OF RADIATION CONTROL RADIOACTIVE MATERIAL LICENSE SUPPLEMENTARY SHEET}

a. Where surfac _.....umination by both alpha- and beta-gamma emitting auclides exists, the limits established for alpha- and beta-gamma emituing nuclides should apply independently.

b. As used in this tabie, dpon (disintegrations per minute) means the rate of emission by radioactive material as determined by correcting the counts per minute observed by an appropriate detector for background, efficiency, and geometric factors associated with the instrumentation.

c. Measurements of average contaminant should not be averaged over more than one square meter. For objects of less surface area the average should be derived for each such object.

d. The maximum contamination level applies to an area of not more than $100 \mathrm{~cm}^{2}$.

e. The amount of removable radioactive material per $100 \mathrm{~cm}^{2}$ of surface area should be determined by wiping the area with dry filter or soft absorbent paper, applying moderate pressure, and assessing the amount of radioactive material on the wipe with an appropriate instrument of know efficiency. When removable contamination on objects of less surface area is determined, the pertinent levels should be reduced proporionally and the entire surface should be wiped.

f. The average and maximum radiation levels associated with surface contamination resulting from beta-gamma emitters shall not exceed 0.2 $\mathrm{mrad} / \mathrm{hr}$ at $1 \mathrm{~cm}$ and $1.0 \mathrm{mrad} / \mathrm{mr}$ at $1 \mathrm{~cm}$, respectively, measured through not more than 7 milligrams per square centimeter of total absorber.

28. B. All trucks, trailers and rail cars used for commercial transport of radioactive material to Envirocare will be decontaminated to the release limits set forth in the following:

TABLE $28-B$

REMOVABLE EXTERNAL RADIOACTIVE CONTAMINATION - WIPE LIMITS

\begin{tabular}{|c|c|c|}
\hline Contaminant & $\begin{array}{l}\text { Maximum } \\
\text { permissible } \\
\text { limits }\end{array}$ & $\begin{array}{l}\text { Maximum } \\
\text { permissible } \\
\text { limits }\end{array}$ \\
\hline & micro $\mathrm{Ci} / \mathrm{cm}^{2}$ & $\mathrm{dpm} / \mathrm{cm}^{2}$ \\
\hline 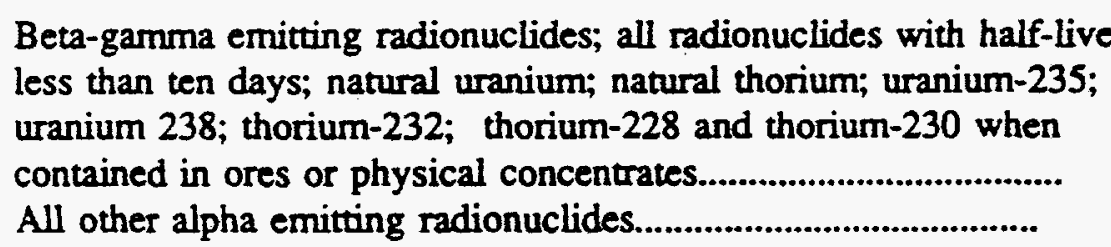 & $\begin{array}{l}10^{-5} \\
10^{-6}\end{array}$ & $\begin{array}{c}22 \\
2.2\end{array}$ \\
\hline
\end{tabular}

Each transport vehicle used for transporting radioactive materials as an exclusive use shipment.. shail be surveyed with appropriate radiation detection instruments after each use. A vehicle shall not be returned to service until the average and maximum radiation levels associated with surface contamination resulting from beta-gamma emitters shall not exceed $0.2 \mathrm{mrad} / \mathrm{mr}$ at $1 \mathrm{~cm}$ and $1.0 \mathrm{mrad} / \mathrm{mr}$ at $1 \mathrm{~cm}$, respectively, measured through not more than 7 milligrams per square centimeter of total absorber, and there is no significant removable (non-fixed) radioactive surface contamination as specified in the above Table $28-\mathrm{B}$.

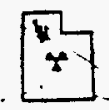

B-159 


\section{TAH DIVISION OF RADIATION CONTROL \\ RADIOACTIVE MATERIAL LICENSE SUPPLEMENTARY SHEET}

Page 3 of 3

License \# UT 2300249

Amendment \#12

\section{CONDITION 65.}

65. Except as specifically provided otherwise by this license, the licensee shall possess and use radioactive material described in Item 6, 7, and 8 of this license and conduct site operations in accordance with statements, representations, operating procedures and disposal criteria, heretofore made by the licensee or his authorized representative in application for and subsequent to issuance of Utah Radioactive Material License No. UT 2300249 and amendments thereto.

UTAH RADIATION CONTROL BOARD
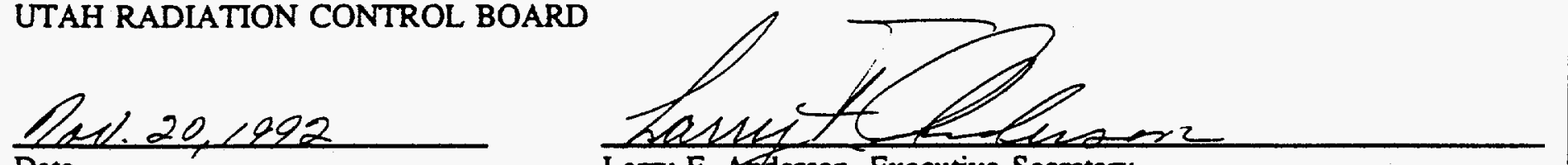

Date 
Appendix C

Point of Origin Inspection Report

C-1 
C-2 


\section{WASHINGTON DEPARTMENT OF HEALTH DIVISION OF RADIATION PROTECTION}

\section{POINT OF ORIGIN INSPECTION REPORT}

A. SUMMARY

\section{GENERAL INFORMATION}

a. Facility Name and Address

b. Contact/Title:

c. Telephone Number:

d. Date of Inspection:

1. Type of Inspections:

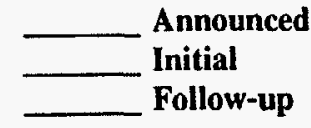

Unannounced

m. Management Summary:

-Opening Conference $(X)$

-Closing Conference (*)

2. a. Previous items of noncompliance noted during last inspection dated were/were not satisfactorily resolved.

b. No items of noncompliance cited during previous inspection dated

c. items of noncompliance found during this inspection.

3. Violations/Items of Concern

Lead Inspector: Date:

Reviewed By: Date:

Reviewed By: Date:

e. Site Use Permit \#

f. Expiration Date:

g. License \#

h. \# of Amendments:

i. License Exp. Date:

j. Inspected By:

k. Type of Licensed Activity:

\section{Special}

Comprehensive

Termination

n. Directions To Facility:

$\bar{\square}$


The purpose of the point of generation inspection is to verify that generators using the US Ecology, Inc. low-level radioactive waste (LLRW) disposal facility are complying with the requirements and intent of Washington Administrative Codes (WAC) Title 246, Chapter 249, and the site operators license. Additionally, the inspection provides the means to help the generator, if any deficiencies in the LLRW program are identified.

\section{B. MANAGEMENT CONTROL}

1. The chain of command for waste generation/disposal is as follows:

(Show chain of command diagram or attach diagram)

2. The RSO is following individual/individuals.

The RSO is assisted by the

$$
\text { . }
$$

3. How many employees are at the facility?

4. How many of the above employees are in the LLRW program?

5. What is the nature of your business?

6. How are personnel generating or packaging the waste kept informed of disposal requirements and regulations?

\section{NOTES:}

7. What is the frequency of training for waste generators/packages?

8. Who conducts the training?

9. Dates of training and subject. 
10. Does the facility have any hazardous waste on site?

11. Where is the hazardous waste stored?

12. How much mixed waste is stored?

13. How is waste checked to ensure no mixed waste is packaged with waste destined for the LLRW disposal facility?

14. Employee Interviews:

Name/Position

Comments

(a)

(b)

(c)

15. Is there a quality control program in place to assure compliance with WAC 246-249-040 (Classification of radioactive waste) and 246-249-050 (Acceptable radioactive waste forms and packaging)?

16. How often are these checks performed?

17. Does the Quality Assurance program for the above include management evaluation of the audits?

NOTES:

18. How often are the management evaluations performed?

19. Are these evaluations and audits documented? 
20. Management evaluation of audits last performed

(a) List or attach any findings of the evaluations/audits for the past year

21. Is there a process control program that validates that liquid wastes are packaged in sufficient approved absorbent material to absorb twice the volume of liquid, solidified using an approved solidification agent, or stabilized using an approved stabilization media?

What is the process for validation?

22. Is there a process control program that validates that solid wastes containing liquid contain as little free-standing liquid as is reasonably achievable, but in no case exceeding one percent by volume?

What is the process for validation?

23. Are the services of a broker used? . If so who is the broker, and what services does the broker provide?

\section{OPERATIONS}

1. Are applicable procedures for the packaging of radioactive waste posted or other wise made available? following waste forms: - Procedures are available for the packaging of the

Are the procedures adequate for the waste streams that are generated?

2. What waste streams are typically generated at this facility?

NOTES: 
3. Are scintillation fluids used? . What type of fluids are used? disposed?

4. Is there a current copy of the disposal site license available at locations were waste is packaged?

5. Is there written guidance at each location where waste is packaged for waste packaging, segregation, etc...?

6. How is waste accountability maintained for each area where waste is generated (ie. radionuclides and activities)?

7. How often is waste collected from each area generating LLRW?

8. If waste is packaged in different areas, a visual inspection of random packages prepared for disposal should be performed.

Package \# Area of Packaging Package Contents

9. If waste is sent to a central packaging location how do the people performing packaging functions know what waste is being transferred?

10. How is the requirement for twice the amount of absorbent to liquid ratio ensured?

11. What absorbent material is used?

NOTES: 
12. If waste is sent to a central packaging location, how do they ensure no waste subject to RCRA or Washington states Dangerous Waste regulations are present?

13. Does the facility incinerate any waste? ash disposed of? . How is the resulting

14. Does the facility compact any waste?

15. How is waste classification determined?

16. How is the concentration of radioactivity determined for each package?

17. How are pathogenic, biological, and infectious material treated to reduce to the maximum extent practicable the potential hazard from non-radiological materials?

\section{PREPARATION FOR SHIPMENT}

1. What is the annual volume of waste disposed at the Hanford LLRW disposal facility?

2. What is the annual activity of waste disposed at the Hanford LLRW disposal facility?

3. How many shipments to the disposal facility have been made in the past year?

4. Is a copy of DOT regulations (49 CFR) on hand?

5. What type of containers are normally uses for waste shipments to the disposal facility? 
6. If 7A specification containers are used, is documentation available and on file showing a complete documentation of tests and that packaging design and materials comply with specification. (Documentation is required for one year after the latest shipment of $7 \mathrm{~A}$ specification containers).

NOTES:

7. How is the information required for manifests compiled?

8. The inspectors independent radiation surveys revealed the following: Package \# Surface reading ( $\mathrm{mr} / \mathrm{hr}) \quad 1$ meter reading $(\mathrm{mr} / \mathrm{hr})$ Smear Result

9. The following instruments were used for the above surveys: Manufacturer Model Serial \# Cal. due date

10. The contents of the following packages were inspected for compliance with the disposal operators license, and WAC 246 - 249:
Package \#
Contents
In Compliance
Discrepancies

11. Are procedures for packaging/shipping available? . Where are the procedures located?

12. How does the generator ensure that packaging is in unimpaired condition prior to packaging? 
13. How does the generator ensure that each closure device including any gasket, is properly installed, secured, and free of defects?

14. How does the shipper ensure proper torque $(40 \mathrm{ft}-\mathrm{lb})$ of locking ring bolts for $7 \mathrm{~A}$ specification drums?

NOTES:

15. How does the shipper ensure that contamination and radiation levels are within allowable limits?

16. Does the shipper have a 24 hour emergency response telephone number that is monitored at all times by a knowledgeable person? What is the emergency phone number? What is the person's name and position that monitors the emergency phone?

17. Are packages properly marked and labeled in accordance with disposal facility license, WAC 246-249, USNRC, and USDOT regulations?

NOTES: 


\section{SUMMARY OF NONCOMPLIANCE/ITEMS OF CONCERN}

